\title{
NUCLEAR FACILITY DECOMMISSIONING AND SITE REMEDIAL ACTIONS
}

\section{A SELECTED BIBLIOGRAPHY Volume 11}

Nancy P. Knox, John R. Webb, Shawn D. Ferguson, Linda F. Goins, and Park T. Owen Remedial Action Program Information Center Biomedical and Environmental Information Analysis

Date of Issue-September 1990

\author{
Supported by the \\ U.S. Department of Energy \\ Office of Environmental Restoratic: \\ and Waste Management
}

Prepared by the Oak Ridge National Laboratory Oak Ridge, Tennessee 37831-6285 operated by MARTIN MARIETTA ENERIYY SYSTEMS, INC. for the

U.S. DEPARTMENT OF ENERGY Under Contract No. DE-AC05-84OR21400 


\section{CONTENTS}

ABSTRACT $\ldots \ldots \ldots \ldots \ldots \ldots \ldots \ldots \ldots \ldots \ldots \ldots \ldots \ldots \ldots \ldots \ldots \ldots$

INTRODUCTION $\ldots \ldots \ldots \ldots \ldots \ldots \ldots \ldots \ldots \ldots \ldots \ldots \ldots \ldots \ldots$ vii

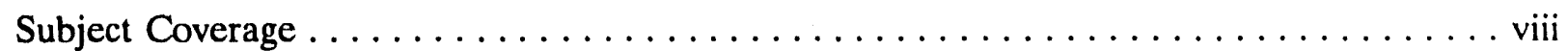

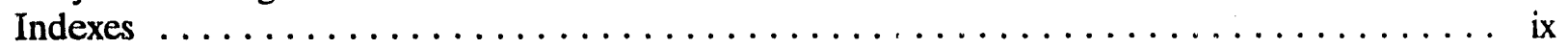

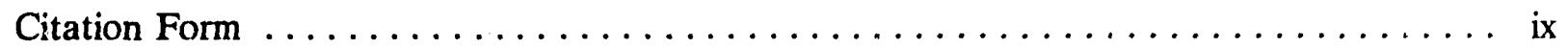

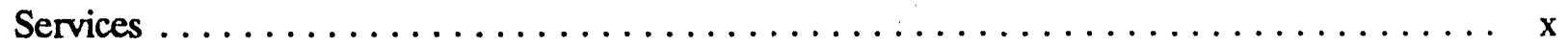

SAMPIE REFERENCE $\ldots \ldots \ldots \ldots \ldots \ldots \ldots \ldots \ldots \ldots \ldots \ldots \ldots \ldots \ldots \ldots$ xii

\section{BIBLIOGRAPHIC REFERENCES}

Surplus Facilities Management Program $\ldots \ldots \ldots \ldots \ldots \ldots \ldots \ldots \ldots \ldots \ldots \ldots \ldots \ldots \ldots$

Nuclear Facilities Decommissioning $\ldots \ldots \ldots \ldots \ldots \ldots \ldots \ldots \ldots \ldots \ldots \ldots \ldots$

Formerly Utilized Sites Remedial Action Program $\ldots \ldots \ldots \ldots \ldots \ldots \ldots \ldots \ldots \ldots$

Facilities Contaminated with Natural Radioactivity $\ldots \ldots \ldots \ldots \ldots \ldots \ldots \ldots \ldots \ldots \ldots$

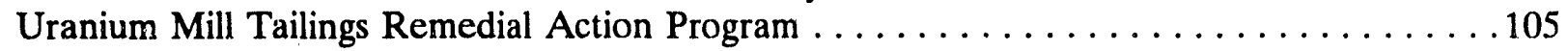

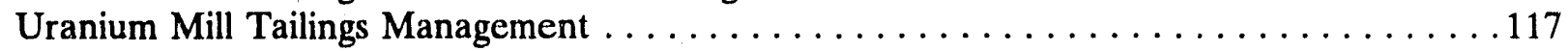

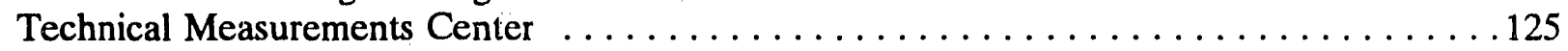

Remedial Action Program . . . . . . . . . . . . . . . . . . . . . . . . 129

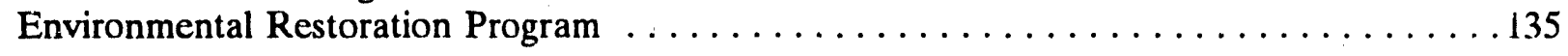

\section{INDEXES}

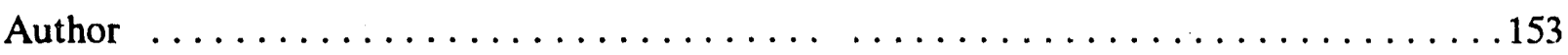

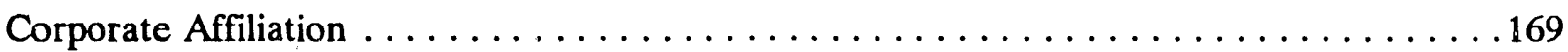

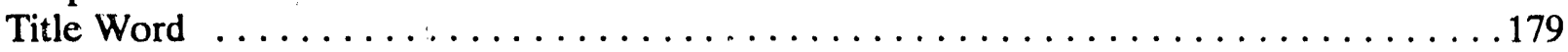

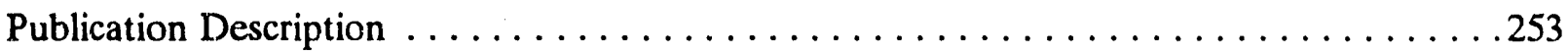

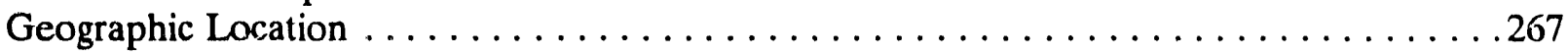

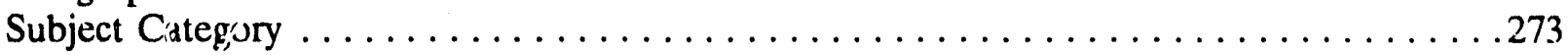

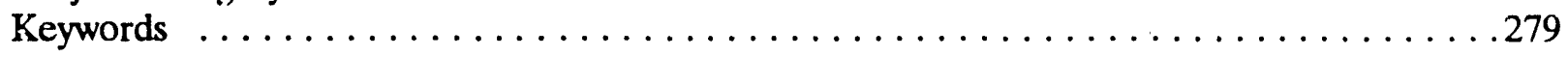

iii/iv 


\begin{abstract}
The 394 abstracted references on environmental restoration, nuclear facility decommissioning, uranium mill tailings management, and site remedial actions constitute the eleventh in a series of reports prepared annually for the U.S. Department of Energy's Remedial Action Programs. Citations to foreign and domestic literature of all types-technical reports, progress reports, journal articles, symposia proceedings, theses, books, patents, legislation, and research project descriptions-have been included. The bibliography contains scientific, technical, economic, regulatory, and legal information pertinent to the U.S. Department of Energy's Remedial Action Programs. Major sections are (1) Surplus Facilities Management Program, (2) Nuclear Facilities Decommissioning, (3) Formerly Utilized Sites Remedial Action Program, (4) Facilities Contaminated with Naturally Occurring Radionuclides, (5) Uranium Mill Tailings Remedial Action Program, (6) Grand Junction Remedial Action Program, (7) Uranium Mill Tailings Management, (8) Technical Measurements Center, (9) Remedial Action Program, and (10) Environmental Restoration Program. Within these categories, references are arranged alphabetically by first author. Those references having no individual author are listed by corporate affiliation or by publication title. Indexes are provided for author, corporate affiliation, title word, publication description, geographic location, subject category, and keywords.

This report is a pruduct of the Remedial Action Program Information Center (RAPIC), which selects and analyzes information on remedial actions and relevant radioactive waste management technologies. RAPIC staff and resources are available to meet a variety of information needs. Contact the center at FTS 624-7764 or (615) 574-7764.
\end{abstract}




\section{INTRODUCTION}

The Remedial Action Program Information Center (RAPIC) is funded by the U.S. Department of Energy (DOE, Office of Environmental Restoration and Waste Management to provide technical information support to DOE's remedial action programs under the direct sponsorship of the following:

- Surplus Facilities Management Program

Lead Office-DOE Headquarters

Lead Technical Contractor-Office of Technical Services

- Weston (Roy F.), Inc.

- H\&R Technical Associates, Inc.

- Formerly Utilized Sites Remedial Action Program

Lead Field Office-DOE Oak Ridge Operations Office

Lead Technical Contractor-Bechtel National, Inc.

- Uranium Mill Tailings Remedial Action Program

Lead Field Office-DOE Albuquerque Operations Office

Lead Technical Contractor-Jacobs Engineering Group, Inc.

RAPIC, which is part of the Biomedical and Environmental Information Analysis section, Health and Safety Research Division, Oak Ridge National Laboratory, serves as an information resource for scientific, regulatory, and socioeconomic aspects of radioactively contaminated facility and site remedial actions. These remedial actions encompass such activities as:

- Performing characterization surveys of radioactively contaminated facilities and sites,

- Conducting ongoing security and surveillance programs,

- Performing preventive maintenance actions to ensure containment of radioactivity awaiting permanent facility disposition,

- Assessing environmental and engineering aspects of proposed remedial action alternatives,

- Drafting cletailed remedial action project plans and procedures, and

- Performing remedial actions to make facilities and sites available for restricted or unrestricted use.

These 394 abstracted references constitute the eleventh annual publication of the same title and subject coverage. The contents of this publication are stored in a comprehensive, computer-retrievable data file that undergoes periodic updating. Most researchers use the published bibliographies as their "first-line" reference tool; however, the cumulative data file can be accessed through RAPIC for the most current additions or for a comprehensive search. 


\section{SUBJECT COVERAGE}

The subject matter of this bibliography is presented in ten sections: Surplus Facilities Management Program, Nuclear Facilities Decommissioning, Formerly Utilized Sites Remedial Action Program, Facilities Contaminated with Natural Radioactivity, Uranium Mill Tailings Remedial Action Program, Grand Junction Remedial Action Program, Uranium Mill Tailings Management, Technical Measurements Center, Remedial Action Program, and Environmental Restoration Program.

The Surplus Facilities Management Program (SFMP) section contains refer ences pertaining to the SFMP, program sites (located primarily on federal reservations), and sp (cific ciecontamination and decommissioning (D\&D) technology developed by the program.

The Nuclear Facilities Decommissioning section presents foreign D\&D information as well as any D\&D technology and domestic site-specific information that is not a part of the SFMP.

The Formerly Utilized Sites Remedial Action Program (FUSRAP) section lists publications pertinent to FUSRAP management or to FUSRAP sites. These sites were used by the Manhattan Engineer District or by the Atomic Energy Commission from the 1940s through the 1960s for the processing, handling, storage, or shipment of radioactive materials.

The section on Facilities Contaminated with Natural Radioactivity contains information detailing remedial action work at industrial or research facilities (other than at FUSRAP sites) that are contaminated with naturally occurring radioactive matcrials.

The Uranium Mill Tailings Remedial Action (UMTRA) Program section contains information pertinent to UMTRA management or to the 24 UMTRA sites, located primarily in the western United States. These sites are inactive uranium mill sites that were operated under government contract.

The section on the Grand Junction Remedial Action Program contains documents pertinent to the remediation efforts conducted at Grand Junction, Colorado.

The section on Uranium Mill Tailings Management contains foreign site-specific information, as well as any bisic or applied research and domestic sitc-specific mill tailings information that is not part of UMTRA.

The Technical Measurements Center (TMC) section lists reports published by TMC, Grand Junction, Colorado, on the subject of detection and measurement of radioactive/hazardous contaminants, instrument calibration, and field calibration facilitics.

The section on Remedial Action Program contains references pertinent to DOE's Division of Facility and Site Decommissioning Projects, Division of Uranium Mill Tailings Projects, or activities associated with two or more of the DOE remedial action programs.

The Environmental Restoration Program section contains references pertinent to activities conducted and plans prepared by DOE's Office of Environmental Restoration. 


\section{INDEXES}

The color-coded indexes are a quick guide to finding needed information. The numbers appearing after each listing in the indexes are citation numbers. The author index (pink pages) lists all authors for each citation. The corporate affiliation index (blue pages) is an alphabetical listing of the institution performing the work. The yellow pages provide a permuted index of all major words in each title (except such pervasive words as decommissioning, decontamination, mill, tailings, etc.). The publication description index (green pages) lists alphabetically all journal names, conference descriptions, report numbers, or other "nique document descriptions that would identify the publication. The gold pages provide an alphabetical index of the geographic descriptions of sites referenced in the bibliography. These are divided into domestic sites and foreign sites. A subject category index (white pages) is provided for the sections on Surplus Facilities Management Program, Nuclear Facilities Decommissioning, Uranium Mill Tailings Remedial Action Program, and Uranium Mill Tailings Management because of the size and diversity of these sections. The subject categories are: Design, Planning, and Regulations; Environmental Studies and Site Surveys; Health, Safety, and Biomedical Studies; Decontamination Studies; Dismantlement and Demolition; Site Stabilization and Reclamation; Waste Disposal; Remedial Action Experience; and General Studics. The keyword index (buff pages) is an alphabetical index of terms selected from a controlled thesaurus to characterize specific concepts.

\section{CITATION FORM}

The references within each section are arranged alphabetically by first author, corporate affiliation, or publication description of the document. When an author is not given for a document, the corporate affiliation will appear first. If these two levels of authorship are not given, the title of the document will appear first, but the citation is integrated into the section by the alphabetical position of its publication description.

Certain printing conventions have been established for this bibliography to express superscripts and subscripts:

1. $\mathrm{X}$ sub $\mathfrak{t}$ means $\mathrm{X}_{\mathrm{t}}$ or $\mathrm{X}$ subscript $\mathrm{t}$.

2. For chemical compounds and elements, $\mathrm{NaIO} 3$ (for example) means $\mathrm{NaIO}_{3}$.

3. $10(E+3)$ or $\mathrm{X}(\mathrm{E}-3)\left(\mathrm{E}\right.$ denoting exponent) means $10^{3}$ or $\mathrm{X}^{-3}$.

4. Cubic or square dimensions of measurements are shown as, for example, $6 \mathrm{cu} \mathrm{cm}$ for 6 cubic centimeters or $3 \mathrm{sq} \mathrm{km}$ for 3 square kilometers.

5. The following prefixes have been used to indicate multiples or subdivisions of units of measurement:

$\begin{array}{llllll}\text { a } & \text { atto } & \left(10^{-18}\right) & \text { da } & \text { deca } & \left(10^{1}\right) \\ \text { f } & \text { femto } & \left(10^{-15}\right) & \mathrm{h} & \text { hecto } & \left(10^{2}\right) \\ \mathrm{p} & \text { pico } & \left(10^{-12}\right) & \mathrm{k} & \text { kilo } & \left(10^{3}\right) \\ \mathrm{n} & \text { nano } & \left(10^{-9}\right) & \mathrm{M} & \text { mega } & \left(10^{6}\right) \\ \mathrm{u} & \text { micro } & \left(10^{-6}\right) & \mathrm{G} & \text { giga } & \left(10^{9}\right) \\ \mathrm{m} & \text { milli } & \left(10^{-3}\right) & \mathrm{T} & \text { tera } & \left(10^{12}\right) \\ \mathrm{c} & \text { centi } & \left(10^{-2}\right) & \mathrm{P} & \text { peta } & \left(10^{15}\right) \\ \mathrm{d} & \text { deci } & \left(10^{-1}\right) & \mathrm{E} & \text { exa } & \left(10^{18}\right)\end{array}$


6. The following abbreviations have been used in this publication for unit measurements:

$\begin{array}{llll}\mathrm{A} & \text { amperc } & \mathrm{l} & \text { liter } \\ \mathrm{a} & \text { acre } & \mathrm{lb} & \text { pound } \\ \mathrm{Bq} & \text { becquercl } & \mathrm{m} & \text { meter } \\ \mathrm{C} & \text { Celsius } & \mathrm{McV} & \text { megaelectronvolt } \\ \mathrm{c.d} . & \text { current density } & \mathrm{min} & \text { minute } \\ \mathrm{Ci} & \text { curie } & \mathrm{Oz} & \text { ounce } \\ \mathrm{cpm} & \text { counts per minute } & \mathrm{ppm} & \text { parts per million } \\ \mathrm{cps} & \text { counts per second } & \mathrm{R} & \text { roentgen } \\ \mathrm{deg} & \text { degree } & \text { rad } & \text { radiation absorbed dose } \\ \mathrm{dpm} & \text { disintegrations per minute } & \text { rem } & \text { roentgen-equivalent-man } \\ \mathrm{dps} & \text { disintegrations per second } & \mathrm{s} & \text { second } \\ \mathrm{F} & \text { Fahrenheit } & \mathrm{Sv} & \text { sievert (dose equivalent) } \\ \mathrm{ft} & \text { feet } & \mathrm{V} & \text { volt } \\ \mathrm{g} & \text { gram } & \mathrm{W} & \text { watt } \\ \mathrm{gal} & \text { gallon } & \mathrm{W}(\mathrm{c}) & \text { watt (electrical) } \\ \text { ha } & \text { hectare } & \mathrm{W}(\mathrm{t}) & \text { watt (thermal) } \\ \mathrm{hr} & \text { hour } & \mathrm{WL} & \text { working level } \\ \text { in. inch } & \mathrm{yd} & \text { yard } \\ \mathrm{keV} & \text { kiloelectron volt } & \mathrm{yr} & \text { year }\end{array}$

\section{SERVICES}

Copies of most documents referenced in this bibliography can be obtained through either the National Technical Information Service, 5285 Port Royal Road, Springfield, Virginia 22161, or the Office of Scientific and Technical Information, U.S. Department of Encrgy, P.O. Box 62, Oak Ridge, Tennessee 37831.

RAPIC provides information support to a large number of researchers involved in the fields of remedial action and radioactive waste management. Certain services such as providing information from RAPIC resources, performing literature searches of computerized databases, and providing assistance in locating hardcopies of documents referenced in the bibliography are provided free of charge to the U.S. DOE's Remedial Action Program staff and their subcontractors. All inquiries for information services should be addressed to:

Remedial Action Pringram Information Center

Oak Ridge National Laboratory

P.O. Box 2008, Building 2001

Oak Ridge, Tennessee 37831-6050

Telephone: FTS 624-7764, 615/574-7764

or

FTS 626-0568, 615/576-0568

FAX: Send FTS 624-9888, 615/574-9888

Telex: 854511 (ORNL IRA-HMI) 


\section{ACKNOWLEDGMENTS}

The authors wish to acknowledge John K. Williams, Romance Carrier, and Woodrow Cottrell of the Health and Safety Research Division, for time reviewing this report. 


\section{SAMPLE REFERENCE}

This is an example of the format for the descriptive fields used in this bibliography:

1-Chapter Heading

2-Record Number

(Sequential Number of Reference)

$3 \rightarrow$ Author(s)

4-Corporate Affiliation
5-Document Title

6-Publication Description

7-Publication Date

8-Abstract

${ }^{1}$ NUCLEAR FACILITIES DECOMMISSIONING

${ }^{2} 191$

${ }^{3}$ Anderson, R.C., and D. T. Dexheimer

${ }^{4}$ Bechtel Power Corporation, San Francisco, CA

${ }^{5}$ INCORPORATING DECOMMISSIONING REQUIREMENTS INTO THE DESIGN PROCESS FOR NUCLEAR POWER PLANTS

${ }^{6}$ CONF-800359; Decommissioning Requirements in the Design of Nuclear Facilities, Proceedings of a Nuclear Energy Agency Specialist Meeting, Paris, France, March 17-19, 1980 (pp. 123-134), 285 pp.

$7^{8}(1980)$

${ }^{8} \mathrm{As}$ a first step in incorporating decommissioning requirements into the design process, greater effort should be made to optimize designs and select alternatives to facilitate decommissioning without adding to the initial cost of the plant. I t this regard, the concept of designing to minimize the plant's oulk quantities of concrete, piping and electrical cables offers a significant opportunity to make the ultimate decommissioning easier. A major design objective should be to build "smaller and lighter" to facilitate decommissioning through the simple reduction of the amount of equipment and structures requiring decontamination, dismantlement, demolition, and disposal. 


\section{SURPLUS FACILITIES MANAGEMENT PROGRAM}


1

Allen, R.P., and A.B. Johnson, Jr., Pac"il Northwest Laboratory, Richland, WA

\section{Shippingport Station Aging Evaluation}

NUREG/CR-5491; PNL-7191; 139 pp. (1990, January)

The Shippingnort Atomic Power Station, the first U.S. large-scale, central-station nuclear plant, now in the final stages of decommissioning, has been a major source of naturally aged equipment for the Nuclear Plant Aging Research (NPAR) and other U.S. Nuclear Regulatory Commission (NRC) programs. Because naturally aged components and materials experience the actual service-related external stressors, corrosion and wear, testing procedures, and maintenance practices, their evaluation is valuable in verifying degradation models, validating aging projections based on the extrapolation of accelerated test data, and detecting unexpected aging mechanisms (surprises) that could significantly impact component or system safety performance. As part of the Shippingport Station aging evaluation work, more than 200 item, ranging in size from small instruments and materials samples to one of the main coolant pumps, have been removed and shipped to designated NRC contractors. Although detailed evaluations of the components and material from the Shippingport Station are just beginning, the preliminary results from the studies conducted to date are indicative of the value of the aging information that ultimately may be obtained.

\section{2}

Argonne National Laboratory, Environmental Assessment and Information Sciences Division, Argonne, IL

Fcasibility Study for Management of the Bulk Wastes at the Weldon Spring Quarry, Weldon Spring, Missouri

DOE/OR/21458-104; 284 pp. (1990, February)

The U.S. Department of Energy (DOE), under Surplus Facilities Management Program (SFMP), is responsible for conducting remedial actions at the Weldon Spring Site Quarry. DOE proposes an interim remedial action prior to overall site remediation to manage the radioactive and chemical bulk wastes in the quarry. This document outlines potential remedial alternatives for managing the quarry bulk wastes which have been developed, screened, and analyzed consistent with EPA/CERCLA guidelines. Based on the analysis in this document, there are three final bulk waste removal alternatives: (1) no action; (2) expedited removal with temporary storage at the Weldon Spring chemical plant area; and (3) delayed action pending the Weldon Spring overall record of decision. The document gives reasons for DOE's preference for (2) the expedited removal of the waste and its temporary storage. This removal alternative would be protective of human health and the environment, can be implemented in a timely manner, and is cost-effective. Potential health effects to the general public and to wort.rs from exposure to chemical and radioactive contaminants as a result of this action would be small.

\section{3}

Argonne National Laboratory, Environmental Assessment and Information Sciences Division, Argonne, IL

Proposed Plan for the Management of Bulk Wastes at the Weldon Spring Quarry, Weldon Spring, Missouri

DOE/OR/21548-105; 18 pp. (1990, February)

The purposes of this document are to: present a notice and brief analysis of the proposed Weldon Spring Site Quarry bulk waste remedial action; describe the remedial action alternatives for this interim action; identify the currently-preferred alternative for managing the bulk wastes and present the rationale for this preference; serve as a companion document to the RI/FS and administrative record file for this action; and outline the public's role in the decision-making process for the action.

4

Becker, D.L., W.W. Bowen, D.M. Burgess, and L.H. Goldmann, Westinghouse Hanford Company, Richland, WA 
Model Testing Conducted to Benchmark the Shippingport Reactor Pressure Vessel/Neutron Shield Tank Safety Analysis Report for Packaging

WHC-SA-0426; 21 pp. (1989, June)

One-tenth size concrete and steel models of the Shippingport Reactor Pressure Vessel/Neutron Shield Tank (RPV/NST) were subjected to free-drop tests as prescribed in the Code of Federal Regulations. Results of the tests provided materials physical and mechanical properties data and reaction rate information to support modeling assumptions and confirm analytical values used in the multidimensional dynamic analyses performed to ensure the structural integrity of the RPV/NST assembly during shipment from Pennsylvania to the Hanford Site in Richland, Washington for final disposaí.

\section{5}

Blanke, J.A., M.M. Benge, and W.F. Stanley, Bechtel National, Inc., Oak Ridge, TN

Performance Monitoring Report for the Niagara Falls Storage Site Waste Containment Structure, Lewiston, New York, July-December, 1988 and Calendar Year 1989

DOE/OR/20722-270; 64 pp. (1990, June)

The performance monitoring program at Niagara Falls Storage Site (NFSS) was initiated in November 1986 to monitor the surface and subsurface conditions of the Waste Ccntainment Structure (WCS). Surface techniques were used to check waste placement, the various layers of the WCS cover, and surface drainage. Internal instrumentation monitors the performance of the clay cap, the gray clay unit, and the cutoff wall/dike. Surface monitoring includes topographic surveys, walkover surveys, and annual aerial photography. The results of the surface monitoring are discussed in Subsection 3.1, and the actions required are discussed in Section 5.0. Internal monitoring instrumentation includes vibrating wire pressure transducers (VWPTs) to monitor pore-water pressure and a secondary system of pneumatic pressure transducers to check on the operation of the VWPTs. Summary information from the environmental monitoring program at NFSS is included in this document in Subsection 3.3. Walkover surveys and data collected from monitoring wells and VWPTs confirm that the WCS is functioning as predicted and is providing isolation for the waste.

6

Boing, L.E., Argonne National Laboratory, Argonne, IL

Project Plan for the Decontamination and Decommissioning of the Argonne National Laboratory Experimental Boiling Water Reactor

ANL-89/32; 48 pp. (1989, December)

In 1956, the Experimental Boiling Water Reactor (EBWR) facility was first operated at Argonne National Laboratory (ANL) as a test reactor to demonstrate the feasibility of operating an integrated power plant using a direct cycle boiling water reactor as a heat source. In 1967, ANL permanently shut down the EBWR and placed it in dry lay-up. This project plan presents the schedule and organization for the decontamination and decommissioning of the EBWR facility which will allow it to be reused by other ANL scientific research programs. The project total estimated cost is $\$ 14.3 \mathrm{M}$ and is projected to generate $22,000 \mathrm{cu}$ ft of low-level radioactive waste which will be disposed of at an approved DOE burial ground.

7

Boing, L.E., D.R. Henley, and F.F. Gorup, Argonne National Laboratory, Argonne, IL; U.S. Department of Energy, Chicago Operations Office, Argonne, IL

Status of the Decontamination and Decommissioning of the Experimental Boiling Water Reactor (EBWR)

Proceedings of the 1989 Annual DOE Model Conference, Oak Ridge, TN, October 3-6, 1989, 54 рp.; (p. 31) (1989, October 3-6)

The Experimental Boiling Water Reactor (EBWR) was built to demonstrate the feasibility of operating 
a dircct cycle boiling water reactor as a heat source. The plant operated from 1956 to 1967 when it was placed in dry lay-up. The facility was accepted into the Department of Energy (DOE) Surpl * Facilities Management Program (SFMP) ir future decontamination and decommissioning. In Phase I of the E\&D (FY 1986 - FY 1988), all nonradioactive items were removed f:om the facility, all preparations were made for removal of radioactively contaminated items, and all asbestos was removed from the facility. In Phase II of the project, which was initiated in FY 1988 , all primary and auxiliary systems will be removed from the facility. This pnase is scheduled to be completed late in .Y 1989. Phase III of the project will consist of disassembly of the reactor vessel complex. A cutting technique will be selected for segmenting of the reactor vessel in late FY 1989. This work is planned to be performed in the period from FY 1989-FY 1992. Phase IV of the project will consist of concrete decontamination arid clean-up from Phase lil. This will be performed. in the period from FY 1993 - FY 1994. A total of 2080 cubic feet of low-'evel radioactive wastes has been disposed of through FY 1988. A total of 2,574 cubic feet of asbestos insulation was removed and disposed of through the same period. In late FY 1989, a radioactive inventory of the reactor vessel will be determined based on a coring plan.

\section{8}

Bumpus, S.E., M.A. Gerhard, J. Hovingh, D.J. Trummer, and M.C. Witte, Lawrence Livermore National Laboratory, Livermore, CA

Benchmarking of the Computer Code and the Thirty-Foot Side Drop Analysis for the Shippingport RPV/NST Package

UCRL-101777; CONF-890601; PATRAM '89: Packaging and Transportation of Radioactive Materials, Proceedings of a Conference, Arlington, VA, June 11-16, 1989; (9 pp.) (1989, June)

This paper presents the benchmarking of a finite eicment computer code and the subsequent results from the code which simulates the 30-ft side drop impact of the reactor pressure vessel/neutron shield tank (RPV/NST) transport package from the decommissioned Shippingport Nuclear Power
Station. The activated RPV, thermal shield, and other reactor external components were encased in concrete contained by the NST and a lifting skirt. The Shippingport RPV/NST package, a Type B Category II package, is $17.5 \mathrm{ft}$ in diameter and 40.7 ft long, and weighs approximately 900 tons. For transport of the activated components from Shippingport to the burial site, the Safety Analysis Report for Packaging (SARP) demor sirated that the package can withstand the hypothetical accidents of DOE Order 5480.3, including 10 CFR 71. Mathematical simulations of these accidents can substitute for actual tests if the simulated results satisfy the acceptance criteria. Any such mathematical simulation, including the modeling of ine materials, must be benchrnarked to experiments that duplicate the loading conditions of the tests. Additional cunfide. $e$ in the simulations is justified if the tests specimens are configured in the same way as the package.

9

Chopra, O.K., and W.J. Shack, Stuttgart University, Staatliche Materialpruefungsanstalt, Stuttgart, Federal Republic of Germany; Argonne National Laboratory, Argonne, IL

\section{Irradiation Embrittement of the Shippingport} Neutron Shield Tank

CONF-8910274; Safety and Reliability of Plant Technology, Proceedings of the 15th MPA Seminar, Stuttgart, Federal Republic of Germany, October 5-6, 1989, Vol. 2, 784 pp.; (pp. 14.1-14.18) (1989)

The results indicate the embrittlement of A212 grade $B$ steel in a low-temperature, low-flux envirnnment. However, the shifts in Charpy transition temperature are lower than those for the high-flux isotope reactor surveillance samples. The data agree well with results from high-flux test reactors. Annealing studies indicate coinplete recovery of embrittlement after a 2 -h anneal ai $400 \mathrm{deg}$ C.

10

Coste, G., Commissariat a l'Energie Atomique, Centre d'Etudes Nucleaires de Fontenay-aux-Roses, Institute de Protection et 
de Surete Nucleaire, Fontenay-aux-Roses, France

\section{Strategy for Dismantling}

Rayonnements Ionisants 4:8-15 (1988)

Long life radioisotopes are produced in nuclear facilities and centuries or millenaries are required for radioactive decay, hence dismantling is a must sooner or later. The main questions are what to do and when. They are also concerned with reactors, plants (uranium production, enrichment and reprocessing) and hot laboratories. Each type of facility is examined protecting safety and the environment. Examples are riven in France. Then situation in the world is briefly reviewed.

11

Duerr, D.

\section{Lift of Shippingport Reactor Pressure Vesscl}

Journal of Construction Engineering and Management 116(1):188 (1990, March)

The Shippingport Atomic Power Station in western Pennsylvania is the first nuciear electric generating station to be decommissioned with the goal of restoning the site to a radiologically clean condition that is acceptable for unrestricted use. In December 1988, the 956-ton (870-T) reactor pressure vessel/neutron shield tank assembly was lifted out of the containment building and loaded onto land transportation equipment in prs , aration for removal from the site and shipment to a burial facility in Washington. This paper reviews the engineering requirements for the lift and removal from containment of the reactor pressure vessel package.

12

Gardner, D.L., Westinghouse Hanford Company, Richland, WA

Sampling Plan for the Unconditional Relcase of Building Materials and Similar Large Components Encountered in Decommissioning

WHC-SA-0877; CONF-9003134; Proceedings of the 1990 Annual Health Physics Society
Meeting, Richland, W.A, March 22, 1990; (6 pp.) (1990, March)

The most efficient sampling plan ior the unconditional release of building materiais and similar large components encountered in decommissioning can be developed without requiring $100 \%$ coverage by measurements on all surfaces. This plan was implemented in the decommissioning of the Shippingport Atomic Power Station. The backbone of the plan was the checking and rechecking of the candidate material so that there was a high degree of assurance that it was releasable before the final survey was performed.

\section{3}

Haroun, L.A., M.M. MacDonnell, J.M. Peterson, and D.J. Fingleton, Argonne National Laboratory, Argonne, IL

Multimedia Assessment of Health Risks for the V'cldon Spring Site Remedial Action Project

CONF-900676; Proceedings of the 1990 Annual Air and Wuste Management Association Meeting and Exhibition, Pittsburgh, PA, June 24-29, 1990; (18 pp.) (1990)

The U.S. Department of Energy (DOE), under its Surplus Facilities Management Program (SFMP), is responsible for cleanup activities at the Weldon Spring site, Weldon Spring, Missouri. The site consists of two noncontiguous areas: the chemical plant area, which includes four raffinate pits, and the quarry. The Weldon Spring site became radioactively and chemically contaminated as a result of processing and disposal activities that took place from the 1940s through the 1960s. The U.S. Department of the Army used the Weldon Spring site to produce dinitrotoluene (DNT) and trinitrotoluene (TNT) explosives from 1941 to 1946 . The U.S. Atornic Energy Commission (AEC), predecessor of DOE, used the site to process uranium and thorium ore concentrates from 1957 to 1966. The quarry was used by the Army and the AEC for waste disposal beginning in the early 1940s; it was last used for disposal in 1969. Wastes placed in the quarry include TNT and DNT residues and radioactively contaminated materials. A summary of disposal activities at the quarry is presented. As part of the 
environmental compliance process a! the Weldon Spring site, a baseline risk evaluation (BRE) was prepared to assess the potential risks associated with contamination present at the quarry.

14

Haroun, L.A., J.M. Peterson, M.M. MacDonnell, and I. Hlohowoskyj, Argonne National Laboratory, Environmental Assessment and Information Sciences Division, Argonne, IL

Baseline Risk Evaluation for Exposure to Bulk Wastes at the Weldon Spring Cuarry, Weldon Snring, Missouri

LOE/OR/21458-065; 108 pp. (1990, January)

The risk assessment is a key component of the RI/FS process, Idressing sites subject to CERCLA and SARA; this document was not prepared to meet specific NEPA requirements, but the analyses are intended to meet its environmental assessment requirements. This baseline risk evaluation was prepared to support proposed action for ranagement of contaminated bulk waste in the Weldon Spring Site, Quarry. The documentation of the risk evaluation focuses on data pertinent to removal of the quarry bulk waste. The risk evaluation assesses potential risks associated with the quarry bulk wastes in the near term. All available physical, them:cal, radiological, hydrogeological, geological, ecological, and demographic data relevant to ihe quarry were evaluated. The objective was to assess the extent of any potential risk to human health and the crivironment resulting from the contamination present at the quarry. The public heali. assessment, using Superfund guidelines, identifies cruntaminants of concern, evaluates exposure to those contaminants, and assesses the potential health effects from exposure by comparing the estimater. average daily exposures to established reference aoses. The environmental assessment is based on site-specific information from characterization studies and environmental monitoring at the quarry; potential environmental impacts are addressed qualitatively. The findings of the risk evaluation emphasize the need for strict control of quarry access in the near term, and implementation of remedial action to ensure long-term health protection. No significant adverse impacts to vegetation and wildlife are evident in the area, but could occur in the future if bulk wastes remain in the quarry.

15

Heine, W.F., and G. Jackson, Westinghouse Hanford Company, Richland, WA

Coping with the Biggest Dismaatling Project in the World - Reactor Decommissioning

Nuclear Engineering International 34(420):24-28 (1989, July)

The dismantling of the eight reactors at Hanford, Washington, will be the largest operation of its kind undertaken anywhere in the world. This article gives an overview of the planning and design for the project.

16

LaGuardia, T.S.

Decommissioning of the Shippingport Atomic Power Station

Decommissioning of Nuclear Facilities, Proceedings of an International Seminar, Lonc-n, United Kingdom, July 6-7, 1988; (26 pp.) (1988, July 7)

The decommissioning of the Shippingport pressurized water reacior (PWR) is discussed with particular emphasis on radioactive decontamination.

17

Landis, M.R., Oak Ridge Associałed Universities, Manpower Education, Research, and Training Division, Oak Ridge, TN

\section{Radiological Survey of the Niagara Falls Storage Site}

ORAU-88/K-112; 103 pp. (1988, December)

The Manhattan Engineering District and the U.S. Atomic Energy Commission (AEC) used portions of the Niagara Falls Storage Site (NFSS) and off-site properties near Lewiston, NY, for storage and 
trans-shipment of radioactive materials, including uranium processing residues and wastes. During the 1970's and early 1980's, additional raciological surveys of the off-site properties identified small amounts of contamination exceeding guidelines for unrestricted areas. The vicinity properties were included in the Formerly Utilized Sites Remedial Action Program (FUSRAP) and NFSS in the Surplus Facilities Management Program (SFMP). Bechtel National, Inc. (BNI) has conducted remedial actions to remove off-site and some on-site contamination and placed the residues and wastes in an engineered containment area at NFSS. Between November 1986-1987, the Oak Ridge Associated Universities (ORAU) conducted a radiological survey of the NFSS to identify locations of residual contamination remaining on the property. This report describes the procedures and results of the survey. The survey includeci measurements of direct radiation levels, radionuclide concentrations in soils, and surface contamination in accessible portions of buildings. Survey findings indicated areas of contamination ranging in size from less than a square meter to several hundred square meters. Contamination was primarily in surface soil; however, at several locations it extended much deeper. The major contaminant is Ra-226, but isolated locations of U-238 and Cs-137 contamination were also noted. Building surfaces showed some elevated levels, but contamination was within guidelines.

18

Landis, M.R., Oak Ridge Associated Universities, Oak Ridge, TN

Verification Survey of the Shippingport Atomic Power Station, Shippingport, Pennsylvania

ORAU-89/K-79; 73 pp. (1989, Novernber)

The Shippingport Atomic Power Station (SAPS) was the first large-scale, central station nuclear in the United States. Plant operations began in 1957 under the direction of the U.S. Atomic Energy Commission; later the plant was operated by the Duquesne Light Company for the U.S. Department of Energy (DOE) (successor to the Atomic Energy Commission). In October of 1982 the Shippingport Atomic Power Station was permanently shutdown, and the reactor core was removed in 1984. In September of 1984 the responsibility for decommissioning the station as assigned to the Surplu: Facilities Management Program at the Department of Energy's Richland Operations Office. The Richland Office established the Shippingport Station Decommissioning Project, and selected General Electric (GE) as the decommissioning operations contractor, to accomplish the task. The purposes of this project were to demonstrate safe and cost effective dismantlement of a large scale nuclear power plant; increase the decommissioning tecinnology base and experience through utilization of subcontractor organizations; and to promote technology transfer for applications in future projects. It is the policy of the DOE's Division of Facility and Site Decommissioning to perform independent (third party) verification of remedial activities. The purpose of these independent verifications is to confirm that remedial actions have been effective in meeting established decontamination and decommissioning guidelines and that the documentation accurately and adequately describes the post-remedial action radiological conditions at the site. The Environmental Survey and Site Assessment Program of Oak Ridge Associated Universities (ORAU) was designated by the DOE's SSDP Office as the independent verification contractor for the SPAS Site. During the period remedial actions were being conducted, ORAU representatives performed independent measurements and sampling at the SAPS Site. In addition, documents describing the project were reviewed, and selected remedial action samples were analyzed for comparison with GE's results. This report describes the procedures and findings of these verification activities.

19

Lo, T.Y., Lawrence Livermore National Laboratory, Livermore, CA

\section{Puncture Evaluation of Shippirigport Package}

UCRL-99652; 12 pp. (19i39, May 26)

A puncture evaluation of a 900-ton type B category II shipping package was performed. The package consisted of the decommissioned Shippingport reactor pressure vessel (RPV) with its neutron shield tank (NST) in a concentric arrangement. The space 
inside the RPV and in annulus between the RPV and the 1-inch-thick NST was filled with concrete. The package was assumed to drop 40 inches into a 6-inch-diameter puncture bar of sufficient length to reach the RPV. The objective was to evaluate the puncture potential of the RPV. A nonlinear dynamic finite element analysis was performed. The NST and the concrete in the annulus were assumed to provide little resistance to puncture because the NST shell is thin and the concrete strength is low. In addition to the dynamic finite element evaluation of the package, a simple buckling analysis of the puncture bar was also performed. The buckling analysis was based on the tangent modulus theory of inelastic buckling. It was found that the puncture bar will not penetrate the RPV under the most severe stress state during the impact process. It was also found that the puncture bar will buckle long before this most severe stress state in the RPV can be reached. The package possesses so much kinetic energy before impact, a small fraction of this energy is sufficient to either buckle or overstress the puncture bar before the stresses in the RPV become critical.

\section{0}

Louie, R.L., and D.R. Speer, Westinghouse Hanford Company, Richland, WA

\section{Decommissioning a 60-M-Tall Exhaust Stack}

Nuclear Technology 86(2):120-127 (1989)

The decommissioning of the Strontium Semiworks Complex, located in the 200 East Area of the Hanford Site, is nearing completion. This facility operated as a pilot plant from 1949 to 1967 to develop fuel reprocessing technology and a method for separating strontium from high.level liquid wastes. Contamination of the facility from these operations was extensive. One of the major activities completed was the decommissioning of the plant exhaust stack. Demolition of the stack was accomplished using explosives. This required decontamination of the stack interior to minimize the release of airborne contamination. Radiation levels in the stack prior to cleaning ranged from 2.5 to $90 \mathrm{mGy} / \mathrm{h}$ as measured along the stack centerline. Decontamination was accomplished by sandblasting, using equipment specially designed and fabricated to allow the work to be performed remotely.
21

MacDonnell, M.M., M.L. Maxey, I.E. Joya, and J.M. Peterson, Argonne National Laboratory, Argonne, IL

Engineering Evaluation/Cost Analysis for the Proposed Management of Contaminated Water Impounded at the Weldon Spring Chemical Plant Area

DOE/OR/21458-106; 212 pp. (1990, July)

This engineering evaluation/cost analysis (EE/CA) report has been prepared to support the proposed removal action for managing contaminated surface waters impounded at the chemical plant area of the Weldon Spring Site, Missouri. Wildlife are currently exposed to the surface waters at the chemical plant area, and contaminants have migrated to underlying groundwater on-site and surface waters off-site. An $\mathrm{EE} / \mathrm{CA}$ was prepared to document the proposed removal action because the water removal is a nontime-critical response, and its documentation is defined by U.S. Environmental Protection Agency (EPA) guidelines for removal actions at CERCLA and SARA sites. The objectives of the EE/CA are: (1) identify the cleanup as a removal action; (2) document the selection of a response that will mitigate the potential release of radioactive or chemical contaminants from the impounded waters into the nearby environment; and (3) address environmental impacts associated with the proposed action. Pursuant to the evaluation of potential alternatives to this report, it is proposed that the water be pumped from the impoundments to a newly constructed treatment plant for contaminant removal. Treated water would then be released to the Missouri River with a permit issued to the U.S. Department of Energy by the Missouri Department of Natural Resources. This action would support comprehensive remedial action planned for the Weldon Spring Site.

\section{2}

McCusker, T.K., EG\&G Idaho, Inc., Idaho Falls, ID

Final Report: Decontamination and Decommissioning of Heat Transfer Reactor 
Experiment Test Assemblies HTRE-2 and HTRE-3

EGG-2575; 51 pp. (1989, September)

The purposes of this report are to describe the decontamination and decommissioning (D\&D) of Heat Transfer Reactor Experiment (HTRE) test assemblies HTRE-2 and HTRE-3 at the Idaho National Engineering Laboratory during 1987, 1988, and 1989, and the conditions existing after completion of D\&D activities. The primary objectives of the $D \& D$ Project were to remove all accessible radioactive and hazardous contamination from the assemblies, to seal all system openings, and to relocate the assemblies from the Test Area North to the Experimental Breeder Reactor-I area in a safe configuration for permanent public display.

23

Meier, J.A., Jacobs Engineering Group, Inc., St. Charles, MO

Characterization of Preferred Groundwater Migration Pathways Weldon Spring Site

Proceedings of the 1989 Annual DOE Model Conference, Oak Ridge, TN, October 3-6, 1989, 54 pp.; (p. 14) (1989, October 3-6)

Through the Weldon Spring Site Remedial Action Project (WSSRAP), the U.S. Department of Energy is currently executing a full remedial investigation/feasibility study and environmental impact statement at the former Weldon Spring Uranium Feed Materials Plant, in compliance with CERCLA/SARP and NEPA guidelines. As a part of the overall envir onmental characterization program, contaminant transport through the various water pathways was nvestigated. The project site and surrounding region is underlain by the fractured and solution-affected Burlington-Keokuk limestone. Small perennial and intermittent springs and losing streams are characteristic of the region. Identification of the transport mechanisms and environmental fate of contaminants is complicated by a "preferred fracture" flow that is superimposed onto a groundwater system which exhibits primarily porous medium flow characteristics. Specific studies have been conducted to evaluate the nature of the solution-affected bedrock and the role these features play in the distribution of site specific contaminants. Chemical analyses of spring waters, waters in ponds and flowing surface watcis, and groundwater have provided an inventory of those features affected by off-site release and assisted in bounding the latera! extent of contaminant distribution via conduit flow. Dye studies initiated through down hole and surface drainage injections have confirmed that there are rapid-transport subsurface connections toward potentially sensitive receptors. Further, data from seepage runs along surface drainages are being reviewed in conjunction with aerial photography to explain the plan-view of the structural lattice which allows for preferred-path migration. Application of these techniques is essential to understanding the complexities which secondary structure and solution effects impose on contaminant migration in carbonate systems.

24

MK-Ferguson Company, St. Charles, MO; Jacobs Engineering Group, Inc., St. Charles, MO

Phase 1 Spring and Seep Report for the Weldon Spring Remedial Action Project, Weldon Spring, Missouri

DOE/OR/21548-045; 73 pp. (1989, August)

The Phase I Spring and Seep sampling effort was undertaken to evaluate the migration of site-related contaminants through conduit type groundwater flow. Samples were collected from springs during both high and low flow stages. Samples were analyzed for uranium, nitroaromatic compounds, CLP metals, and inorganic anions. Eight of the 27 springs which were sampled in a 2 mile radius of the site were found to contain levels of contaminants above calculated background levels. This report details the rational, sampling and analytical methodologies, the analytical results, and the interpretation of transport mechanisms for each of the positive results.

\section{5}

MK-Ferguson Company, St. Charles, MO; Jacobs Engineering Group, Inc., St. Charles, MO

Radiological and Chemical Characterization Report for the Planned Quarry Construction 


\section{Staging Area and Water Treatment Plant: Revision 1}

\author{
DOE/OR/21548.046 (Rev. 1); 51 pp. (1989, \\ March)
}

The Quarry Construction Staging Area and Water Treatment Plant (QCSA) will be used in the support of the bulk waste removal of the Weldon Spring Quarry. Radiological and chemical cilaracterization was performed on a 12 acre site where the QCSA will be constructed. The characterization revealed approximately 0.5 acres of radiologically contaminated land. No chemical contamination was found.

\section{6}

MK-Ferguson Company, St. Charles, MO; Jacobs Engineering Group, Inc., St. Charles, MO

\section{Temporary Storage Area Characterization Report \\ DOE/OR/21548-063; 272 pp. (1990, January)}

The preferred alternative identified in the RI/FS for the Weldon Spring Quarry bulk wastes is to remove the wastes from the quarry and transport them by truck to a temporary storage facility at the chemical plant site. To support the RI/FS, this report provides data to characterize the temporary s.orage area (TSA) site and to ensure the suitability of the proposed location. The data are drawn from studies conducted in connection with the Weldon Spring Site Remedial Action Project but are focused specifically on that information pertinent to defining contamination within the proposed 13-acre TSA site. Information is also presented regarding the physical features of the surface of the TSA site and the geotechnical suitability of the earth materials for liner construction and foundation support. The geotechnical data supports the suitability of the site for temporary storage. The engineering properties of the Ferrelview Formation and the underlying clay till unit are consistent with the design criteria for liner materials. Prior to construction of the proposed facility, three buildings will have to be remo\%ed, along with inactive utility lines, fencing and a decontamination pad. Active water lines will be relocated.
27

MK-Ferguson Company, St. Charles, MO; Jacobs Engineering Group, Inc., St. Charles, MO

\section{Remedial Investigations for Quarry Bulk Wastes}

DOE/OR/21548-066; 380 pp. (1989, December)

The U.S. Department of Energy (DOF) proposes to remove the bulk wastes from the Weldon Spring Quarry (WSQ) as a separate operable unit of the remedial action of the Weldon Spring Site Remedial Action Project (WSSRAP). The proposed removal is scheduled to be conducted prior to the record of decision for the WSSRAP. DOE has submitted an Enginecring Evaluation/Cost Analysis for removal and treatment of contaminated water from the pond within the quarry, which must be done before the bulk waste removal begins. The quarry is contaminated with radioactive and chemical materials deposited during Department of the Army and Atomic Energy Commission (AEC) activities between 1942 and 1969. In support of the proposed removal, this remedial investigation (RI) report summarizes and evaluates information from pertinent studies completed over the years by Army, AEC, and DOE contractors and other agencies. It is estimated that approximately 95,000 cubic yards of contaminated waste material (structural debris, drummed and unconfined wastes, process equipment, sludges, and other solids) have been deposited in the quarry. Uranium, thorium, radium, and radon are the radioactive constituents of concern; chemical contaminants include nitroaromatic compounds, polynuclear aromatic hydrocarbons, polychlorinated biphenyls, and heavy metals. The pond water in the quarry and groundwater in the limestone bedrock of the quarry contain elevated levels of all contaminants. This may pose a risk of future contamination to St. Charles County drinking water. To mitigate this isk, and to further characterize the site and waste for additional remedial activities, DOE proposes to remove the bulk wastes and place them in storage at the raffinate pits and chemical plant area of the WSS. In addition to this RI report, a baseline risk evaluation for the bulk waste removal is documented in a separate companion report. A feasibility study for the proposed removal is under way. 
28

MK-Ferguson Company, St. Charles, MO; Jacobs Engineering Group, Inc., St. Charles, MO

Phase 2. Groundwater Quality Assessment for the Weldon Spring Site, Chemical Plant, Raffinate Pits and Surrounding Vicinity Properties

DOE/OR/21548-078; 81 pp. (1989, August)

This report brings together the most current information (through the third quarter of 1988) on groundwater contamination in the Weldon Spring Chemical Plant/Raffiration Pits (WSCP/WSRP) area and vicinity properties (WSVP) of the Weidon Spring Site (WSS). In 1988 the monitoring well network was extended by the addition of 33 new wells installed at two depths so they could be used for vertical and lateral characterization. The analytical categories for the study were inorganic anions, nitroaromatic compounds, radiochemical parameters, metals, and total organic carbon. Samples were collected in compliance with Weldon Spring Site Remedial Action Project (WSSRAP) procedures. Duplicate and spiked samples were used to verify the accuracy and precision of the analytical procedures. Although the installation of new monitoring did fill many data gaps with regard to vertical and lateral contamination migration, some additional lateral data gaps have been identified.

\section{9}

MK-Ferguson Company, St. Charles, MO; Jacobs Engineering Group, Inc., St. Charles, MO

Evaluation of Kadon Emissions and Potential Control Requirements

DOE/OR/21548-082; 37 pp. (1989, August)

This report provides estimates of radon release rates at the Weldon Spring Quarry (WSQ) for existing conditions and conditions which are expected to exist as the bulk waste is excavated. It also estimates radon release rates for the Temporary Storage Area (TSA). In 1989, Rn-222 concentrations at the fence line exceeded DOE guidelines. Data on working level concentrations at one monitoring station indicate an effective whole body dose rate of 0.75 $\mathrm{mrem} / \mathrm{hr}$ for radon daughters and $0.72 \mathrm{mrcm} / \mathrm{hr}$ for thoron daughters at one meter above the quarry waste. Since some of the calculations are based on assumptions, they show only the relative difference in radon release between present conditions and either of two excavation scenarios. They can be used in calculations of public exposure and potential heaith affects to evaluate the relative merits of each excavation scenario in comparison with present relcasc conditions.

30

MK-Ferguson Company, St. Charles, MO; Jacobs Engineering Group, Inc., St. Charles, MO

WSSRAP (Weldon Spring Sitc Remedial Action Project) Quarry Preliminary Enginccring Report

DOE/OR/21548-094 (Rev. ?); 122 pp. (1990, January)

The removal, transport, and temporary storage of radiologically and chemically contaminated bulk waste from the Weldon Spring Quarry will be accomplished by dividing the work into three subcontract packages. The major portion of the work will come under the bulk waste excavation package. Construction of a temporary storage area (TSA) at the Weldon Spring Chemical Plant and of a haul road butween the quarry and the TSA comprise the other two packages. Cost estimates to complete the removal range from $\$ 5$ million to $\$ 9.4$ million due to a high degrec of uncertainty regarding both the productivity of the excavating equipment. and the effectiveness of planned dewatering efforts. Quarry wastes will be substantially dewatered, and the water treated before discharge. Waste will be excavated in three phases, using conventional construction equipment, with preliminary sorting of waste at the quarry before transport to the TSA. Special attention will be given to controlling the spread of contamination by carcful monitoring and control of surface and groundwater drainage and of particulate and radiological contamination of the air.

31

MK-Ferguson Company, St. Charles, MO; Jacobs Enginecring Group, Inc., St. Charles, MO 
Buildings Radiological Characterization Report for the Weldon Spring Site Remedial Action Project, Weldon Spring, Missouri

DOE/OR/21548-120, 242 pp. (1990, April)

This report summa-izes radiological characterization data on the Weldon Spring Chemical Plant (WSCP) buildings, gathered as part of five previous investigations, and provides a consistent interpretation of this data. The data and data interpretation will be used to support future feasibility studies, which will determine the best available technologies for ultimate disposition of the buildings and associated equipment. At present, no structure or piece of equipment can be released from the WSCP for unrestricted use without further raciation measurements being performed. Some equipment and building components contain levels of surface radioactivity far below the U.S. Department of Energy (DOE) unrestricted use release guidelines and may require only spot-check measurements to be released for unrestricted use. Other equipment and building components contain surface radioactivity levels rear the DOE guidelines and will probably require $100 \%$ scanning of all extcrior surfaces to be released for unrestricted usc. Equipment and building components containing surface radioactivity levels far below or near the DOE guidelines were usually found in those buildings not used for the actual processing of uranium and/or thorium. A final group of equipment and building components contains surface radioactivity levels in excess of DOE guidelines. This group, usually found in buildings housing uranium and/or thorium processing equipment, will require decontamination and comprehensive scanning to be considered for unrestricted use release.

\section{2}

MK-Ferguson Company, St. Charles, MO; Jacobs Engineering Group, Inc., St. Charles, MO

Plan for Monitoring Radionuclide Emissions Other than Radon at Weldon Spring Site Critical Receptors

DOE/OR/21548-127; 33 pp. (1990, May)

During the course of the Weldon spring Site Remedial Action Project (WSSRAP) radionuclides may be emitted to the air. Emissions of radionuclides are regulated by the U.S. Environmental Protection Agency in $40 \mathrm{CFR}$ 61. It is clear in 40 CFR 61 that, for sites being remediated according to the Comprehensive Environmental Response, Compensation, and Liability Act (CERCLA), no monitoring or reporting of radon emissions is required prior to completion . temporary or permanent disposal sites, other thait that already required under CE'RCLA. For radionuclides other than radon, however, it is not clear whether 40 CFR 61 requires sites being remediated according to CERCLA to implement additional monitoring and reporting prior to completion of disposal facilities. Because the U.S. Department of Energy (DOE) is committed to protection of the public and environment, a plan nas been formulated which defines how the WSSRAP will implement a monitoring program for radionuclides other than radon. This plan ad'aeres to the specifications contained in 40 CFK 61. The monitoring, reporting, and quality assurance program is discussed.

\section{3}

MK-Ferguson Company, St. Charles, MO; Jacobs Engineering Group, Inc., St. Charles, MO

\section{Assexsment of Ash Pond Isolation Project Effectiveness}

DOE/OR/31548-109; 42 pp. (1990, February)

In April, 1989, DOE completed the Ash Pond Isolation Project at the Weldon Spring Site Remedial Action Project (WSSRAP). This Interim Response Action (IRA) was designed to reduce uranium concentrations in surface water released from the Ash Pond Outfall at the Weldon Spring Site (WSS). Uranium concentrations at this outfall have been measured as high as $5,500 \mathrm{pCi} / \mathrm{L}$ with an average concentration of $1,498 \mathrm{pCi} / \mathrm{L}$. This project was one of several IRAs aimed at improving health and safety conditions at the WSS prior to the Record of Decision. The Ash Pond Isolation Project was constructed to intercept surface water runoff to the Ash Pond drainage and redirect flows around the Ash Pond and South Dump areas, therroy climinating leaching and transport of uranium-contaminated materials from these source 
areas. The DOE has monitored the releases from the Ash Pond Outfall in fulfillment of the site's National Pollutant Discharge Elimination System Permit and initiated additional monitoring to further assess the effectiveness of the Ash Pond Isolation Project. Results of this monitoring effort indicate a reduction in uraniurn concentrations measured at the Ash Pond Outfall from a pre-completion average of $1,498 \mathrm{pCi} / \mathrm{L}$ to an average of $145 \mathrm{pCi} / \mathrm{L}$ following completion of the IRA.

\section{4}

Paustenbach, D.J.

The Risk Assessment of Environmental and Human Hazards

John Wiley and Sons Inc., New York, NY; 1600 pp. (1988)

A complete handbook for conducting risk assessments for environmental and occupational health hazards. This casebook, the first of its kind, presents 22 case studies, including many of the most important and thorough risk assessments ever conducted. It describes state-of-the-art approaches to assessing the low-dose response, estimating exposure, and evaluating the risks to birds and fish. It also serves as a how-to-text, as well as a refernnce for developing high quality environmental and human health risk assessments. Diverse hazards are covered, such as waste sites; contaminated air, soil, and water; consumer products; and indoor air. All assessments are fully documented and referenced.

\section{5}

Rosinski, S.T., and W.J. Shack, Sandia National Laboratories, Albuquerque, NM

Shippingport Neutron Shield Tank Sampling and Analysis Program

SAND-88-1761C; 8 pp. (1988)

The U.S. Department of Energy (DOE) and the U.S. Nuclear Regulatory Commission (NRC) are supporting work at Sandia National Laboratories (SNL) and Argonne National Laboratory (ANL), respectively, to obtain disc samples from the Shippingport Station neutron shield tank (NST).
36

Rosinski, S.T., W.J. Shack, and O.K. Chopra, Sandia National Laboratories, Albuquerque, NM

Irradiation Embrittlement Investigation of the Shippingport Station Ncutron Shicld Tank

SAND-88-3347C; 11 pp. (1989)

A joint effort between the U.S. Nuclear Regulatory Commission and the U.S. Department of Energy is under way to investigate the low-temperature, low-fluency rate embrittlement of reactor vessel support structures through analysis of the decommissioned Shippingport Station neutron shicld tank (NST). The Shippingport NST operated at a temperature of $130 \mathrm{deg} F(55 \mathrm{deg} \mathrm{C})$ and saw a maximum flucncy of approximately $6 \times 10(\mathrm{E}+17)$ $\mathrm{n} / \mathrm{sq} \mathrm{cm}$, energies greater than $1 \mathrm{MeV}$. To characterize the embrittlement behavior of the NST material, eleven 6-inch diameter discs were removed from the irradiated inner shell of the NST along with the corresponding material from the slightly irradiated outer shell. Standard Charpy V-notch tests on the most highly irradiated NST material indicate a shift in the transition temperature (mcasured at $15 \mathrm{ft}-\mathrm{lbs}$ ) of approximately $45 \mathrm{deg} \mathrm{F}(2.5$ deg C) after 9.25 effective full power years of operaition. This shift is not as severe as that expected based on surveillance results at the High Flux Isotope Reactor. The resultant transition temperature, however, is close to the NST service temperature. A low toughness at service temperature is also indicated.

\section{7}

Schreiber, J.J., U.S. Department of Energy, Shippingport Station Decommissioning Project Office, Shippingport, PA

\section{Completion of Shippingport Reactor Decommissioning}

DOE/SSDP-0082; 53 pp. (1989, October)

Planning for the decommissioning of the Shippingport Atomic Power Plant began in 1979 and ended with publication of the Decommissioning Plan in 1983. The site was available for occupation by the Decommissioning Operations Contractor in September 1984 and physical work on 
decommissioning commenced in September 1985. This physical work was completed 3.75 years later, almost 6 months ahead of schedule. The total cost will be $\$ 92 \mathrm{M}$ which is $\$ 6 \mathrm{M}$ less than the $\$ 98 \mathrm{M}$ estimated. A breakdown of planned and actual statistics is presented for various aspects of the decommissioning work including: Cost, schedule, manpower, radiation exposures, waste arisings and shipments. Various aspects concerning contracts, decontamination, asbestos, safety, lessons learned and technology transfer are also presented.

\section{8}

Shack, W.J., O.K. Chopra, and H.M. Chung, U.S. Nuclear Regulatory Commission, Division of Enginecring, Washington, DC

\section{Aging Studics on Materials from the} Shippingport Reactor

NUREG-0975 (Vol. 7); Compilation of Contract Research for the Materials Engineering Branch, Division of Engineering - Annual Report for FY 1988; (pp. 217-232) (1989, May)

The objective of this program is to develop an understanding of the metallurgical phenomena that may occur in nuclear reactor structural ma*erials as a consequence of extended service at operating temperatures within and outside of the radiation environment and to assess the impact of these phenomena on structural integrity. The Shippingport reactor offers a unique opportunity to validate and benchmark the laboratory studies, and thereby, provide a sound basis for evaluating the integrity of structural components near the end of the projected life of a plant. Additional work will be undertaken to identify possible new mechanisms of component degradation. As the opportunity arises, additional materials will be procured from other reactors, and the extent of degradation in these materials will be evaluated and compared with results from the Shippingport components. The work in the program is currently divided into four tasks: (1) procurement of materials from Shippingport and other operating reactors, (2) study of the aging degradation of cast-duplex stainless stecl, (3) irradiation embrittlement and SCC of irradiated components, and (4) exploratory aging studies. The work during the current year has focused on the procurement and characterization of samples from the ncutron shield tank of the Shippingport reactor, and the characterization of aged cast stainless steel samples obtained from the primary piping of the Shippingport reactor.

\section{9}

Shulman, B.

\section{When a Nuclcar Reactor Dies, $\$ 98$ Million is a Chcap Funcral}

13 pp. (1989, October)

The Shippingport reactor vessel was not dismantled but was shipped whole for burial to the Hanford Military Reservation in southeastern Washington by barge and by truck - a total trip of 8,100 miles at a cost of 92 million. The project is being used by the U.S. Department of Energy (DOE) as a model to show that nuclear reactors can be shut down and disposed of safely. However many environmental groups disagree stating that by today's standards the Shippingport is very small and that the larger commercial reactors will require at least partial dismantlement at the reactor site before any shipment is made, and this will be a much more costly affair in terms of technology and radiation protection measures. The questions also remains as " where these future retired reactors are to be shipped. To date no sites have been designated much less prepared to receive such a conglomerate and volume of wastes which will have to be safely stored for at least 1000 years.

40

Sigmon, C.F., and M.B. Levine, Oak Ridge National Laboratory, Oak Ridge, TN

\section{Environmental Compliance Assessment Findings for Weldon Spring Site Remedial Action Program}

ORNL/M-1149; 39 pp. (1990, March 2)

This report presents the results of an environmental assessment conducted at the Weldon Spring Site Remedial Action Project (WSSRAP) in St. Charles County, Missouri, in accordance with the Formerly Utilized Sites Remedial Action Program (FUSRAP) 
Environmental Compliance Assessment Checklists. The purpose of this assessment was to evaluate the compliance of the site with applicable federal and Missouri environmental regulations. Assessment activities included the following: review of site records, reports, and files; inspection of the WSSRAP storage building, other selected buildings, and the adjacent grounds; and interviews with project personnel. This assessment was conducted on August 28-30, 1989. The assessment covered five management areas as set forth in the Checklist: Hazardous Waste Management, Polychlorinated Biphenyls (PCBs) Management, Air Emissions, Wastewater Discharges, and Petroleum Management. No samples were collected.

\section{1}

U.S. Department of Energy, Weldon Spring Site Remedial Action Project Office, St. Charles, MO

\section{Weldon Spring Chemical Plant Water Treatment Plan}

Information Bulletin; 6 pp. (1990)

This bulletin is for the people of St. Charles and St. Louis counties who want to participate in decisions regarding the U.S. Department of Energy's (DOE's) plan for treatment of contaminated surface water impounded at the Weldon Spring Chemical Plant site. It gives an overview of the plan, including the plan's purpose, a conceptual layout of the water treatment system, hypothetical questions and answers, and a brief summary of remedial actions completed to date at the Weldon Spring Site. A public meeting to describe these plans and receive public comment on the proposed water treatment action at the chemical plant area is scheduled for August 16, 1990.

\section{2}

U.S. Environmental Protection Agency, Office of Emergency and Remedial Response, Washington, DC

Superfund Record of Decision (EPA Region 8): Monticello Vicinity Propertics, Utah (First Remedial Action), September 1989 - Final Report
PB-90-197625; EPA/ROD/R-08-89/025; 28 pp. (1989, September 29)

The Monticello Vicinity Pirperties site, also known as the Monticello Radiation Contaminated Properties, is a federally owned abandoned vanadium and ${ }^{\prime}$ ranium mill area in the city of Monticello, San Juan Cotinty, Utah. Milling of vanadium and uranium occurred from 1944 to 1960 . Throughout the operating period, mill tailings were used in the city of Monticello for construciion purposes including fill for open lands; backfill around rater, sewer, and electrical lines; sub-base for driveways, sidewalks, anci concrete slabs; backfill against basement foundations; and sand mix in concrete, plaster, and mortar. The Vicinity Properties were formally included on the NPL in 1986 and, therefore, must comply with requirements of CERCLA. In October 1989 the millsite itself was also listed on the National Priorities List. DOE established an official list of Vicinity Properties designated for remedial action based on radiological surveys conducted from 1971 to 1984. As of March 1989, 91 properties had been identified to be included in the Monticello Vicinity Properties. Of these 91 properties, 53 remedial actions have been completed and 12 additional properties are slated for remedial action in 1989. Approximately 100,000 cubic yards $(135,000$ tons) of contaminated construction debris and wind blown deposited contamination is estimated to be within the Vicinity Properties. The primary contaminants of concern in construction material and debris are thorium-230, radium-226, and radon-222. contained in the vanadium and uranium mill tailings.

\section{3}

\section{Weldon Spring Quarry}

Information Bulletin; 1 p. (1989)

This is an information bulletin for the people of St. Charles County who want to participate in decisions regarding the United States Department of Energy's plans for the cleanup of the Weldon Spring Quarry. In February of last year the U.S. Department of Energy (DOE) presented a plan to remove and treat contaminated water from the Weldon Spring Quarry. The water treatment plant that will do this work is now being designed and constructed. This bulletin announces the DOE proposal for the next step in the 
quarry cleanup process. Documents describing this proposal are provided to public and comments are invited.

\section{4}

Westinghouse Hanford Company, Shippingport Station Decommissioning Project Office, Shippingport, PA

\section{Shippingport Station Decommissioning Project: Removal of Pipiry and Equipment and Removal of Primary System Components - Topical Report}

DOE/SSDP-0053; 51 pp. (1989, October 17)

This report is a technical synopsis of the removal of contaminated and noncontaminated piping and equipment from the Shippingport Station Decommissioning Project (SSDP). The information is provided as a part of the Technology Transfer Program to document dismantling activities in support of reactor decommissioning. The report covers initial management decisions, engineering requirements, operations, schedule performance, tools and equipment, waste handling and lessons learned. Selected photographs of the piping and equipment removal tasks are provided in the text where appropriate.

45

Westinghouse Hanford Company, Shippingport Station Decommissioning Project Office, Shippingport, PA

Shippingport Station Decommissioning Project: Activity Specification 12 - Decontamination, Topical Report

DOE/SSDP-(0)76; 37 pp. (1989, September 28)

This topical report is a synopsis of the decontamination of plant components and structures at the Shippingport Station Decommissioning Project (SSDP). The information is provided as a part of the Technology Transfer Program to document the preparation activities in support of the shipment of radioactive wastes and the unconditional release of the site and structural matcrials.
46

Westinghouse Hanford Company, Shippingport Station Decommissioning Project Office, Shippingport, PA

Shippingport Station Decommissioning Project: Removal of Structures and Containment Thambers - Topical keport

DOE/SSDP-0080; 41 pp. (1989, November 28)

This report is a synopsis of the activity to demolish, dismantle, and remove structures and the containment chambers during the Shippingport Station Decornmissioning Project. The information is piovided as a part of the Technology Transfer Program to document dismantling activities in support of reactor decommissioning. Additional detail may be obtained from subcontractor reports noted in the reference section of this report.

47

Westinghouse Hanford Company, Shippingport Station Decommissioning Project, Shippingport, PA

Shippingport Station Decommissioning Project Final Project Report

DOE/SSDP-0081; 81 pp. (1989, December 22)

This report is intended to provide an overview of the Shippingport Station Decommissioning Project (SSDP). Partics interested in additional project detail are directed to Section 2.11 Site Technology Transfer Program and its Appendix A of this report for a description of the type of information available and the source from which it can be obtained. Additionally, references have been placed at appropriate points in this report to indicate Technology Transfer material available on that subject. The SSDP mission was to make the nuclear portion of the Shippingport Atomic Power Station safe from a radiation standpoint. These objectives were established: (a) demonstrate safe and cost effective dismantlement of large full scale nuclear fucled electric power plant; (b) optimize number of subcontractors to induce a transfer of decommissioning experience to the nuclear industry; and (c) provide for technology transfer by generation of project performance data and documentation of 
decommissioning experience for use in future decommissioning projects. The technical approach for the SSDP was to: (1) remove all government owned structures to three feet below grade; (2) dispose of all nuclear waste at the U.S. Department of Energy Hanford Reservation; (3) remove and ship the Reactor Pressure Vessel/Neutron Shield Tank as a single component; and (4) release the site for unrestricted use and return it to the owner, Duquesne Light Company. The total estimated cost, including planning, was $\$ 98.3$ million, with operations scheduled to begin in September 1984 and to conclude in April 1990. Final costs were a total of $\$ 91.3$ million with actual operations completed in September 1989. Physical decommissioning was done from September 1985 to July 1989. The property was returned to Duquesne Light Company by DOE on December 29, 1989.

\section{8}

Westinghouse Hanford Company, Shippingport Station Decommissioning Project, Shippingport, PA

\section{Shippingport Station Decommissioning Project - FY 1989 Annual Progress Report}

DOE/SSDP-0083; 39 pp. (1989, November 30)

This report present progress on the Shippingport Station Decommissioning Project for FY 1989
(October 1, 1988 - September 31, 1989). There are two main topics: (1) Project Management and (2) Decommissioning Project Activities. Changes from technical and managerial concepts developed in the original Decommissioning Plan are presented with the related technical, economic, or schedule considerations.

\section{9}

Witte, M.C., and C.K. Chon, Lawrence Livermore National Laboratory, Livermore, CA

\section{A Structural Evaluation of the Shippingport Reactor Pressure Vessel for Transport Impact Conditions}

UCRL-100788; 9 pp. (1989, March 24)

The Shippingport Atomic Power Station in Shippingport, Pennsylvania, is being decommissioned and dismantled. This government-leased property will be returned, in a radiologically safe condition, to its owner. All radioactive material is being removed from the Shippingport Station and transported for burial to the U.S. Department of Energy, Hanford Reservation in Richland, Washington. The reactor pressure vesscl (RPV) will be transported by barge to Hanford. This paper describes an evaluation of the structural response of the RPV to he normal and accident impact test conditions as required by the Code of Federal Regulations. 
$19 / 20$

NUCLEAR FACILITIES

DECOMMISSIONING 
50

Afanas'ev, S.D., R.N. Grinkevich, and E.O. Mazarovich

\section{NPP Safety Problems}

Energeticheskoe Stroitel'stvo za Rubezhom 2:9-15 (1989, April)

Main trends in improving the nuclear power plant (NPP) designs from the viewpoint of their safety are described. Problems of the NPP decommissioning and organization of reliable burial of radioactive wastes are considered.

51

\section{A.GRs - The Reckoning}

Power Europe 64:9-11 (1989, December 7)

The cost of the cleanup activities for the Magnox and Advanced Gas-Cooled reactors (AGR) in Britain is discussed. The AGRs are not now to be privatized and so the government will be responsible for the decommissioning, waste reprocessing, and waste management costs, which are difficult to estimate but which will be high. The need for reprocessing the AGR fuel is discussed. Some fuel for reprocessing has already been contracted to British Nuclear Fuels, Limited at Sellafield. The rest could either be reprocessed, stored dry, or stored wet, and the relative costs of these strategies are estimated. The nonreprocessing option is shown to be cheaper. Money needs to be allocated whichever option is chosen, either by the government directly or through an increase in electricity prices. However, the government would like to lower the cost of nuclear-generated electricity.

\section{2}

Alder, J., National Cooperative for the Storage of Radioactive Waste, Baden, Switzerland

\section{Preliminary Studies of Packaging and Disposal of Decommissioning Waste in Switzerland}

Nuclear T'echnology 86(2):197-206 (1989, August)
In Switzerland, studies have demonstrated the feasibility of the safe disposal of all types of nuclear waste. Decommissioning wastes from the five existing Swiss nuclear plants can be classified into different types for disposal purposes, based on these studies. These wastes are assumed to be packaged in large (20-cu m) containers. Requirements for the waste packages are determined and are severe for the highly radiating and heat-producing waste. Results from safety analyses of a proposed underground repository for low- and intermediate-level waste are applied to these decommissioning waste types. Expected doses from disposal of the waste in the underground repository, as well as in a near-surface repository, provide a basis for a classification of the waste for the two types of repositories. Wastes can then be allocated to appropriate disposal facilities that can provide the required degree of safety.

53

Andersen, C.B.

Comparison Between Laser, Plasma, Waterjet, Oxygen Cutting and Other Mechanical Cutting Processes for Low Thickness (0.5 Up to 5 MM)

Welding in the World 25(5/6):88-99 (1987)

This document gives a comparison between laser, plasma, waterjet, oxygen cutting and other mechanical cutting processes for low thickness $(0.5$ up to $5 \mathrm{~mm}$ ). The following cutting processes were cvaluated: (1) Oxygen Cutting, (2) Plasma Cutting, (3) Laser Cutting, (4) Water Cutting, (5) Shearing, (6) Punching, and (7) Nibbling. The document does not evaluate the possibilities for the combinations punching/laser cutting, punching/plasma cutting or other cutting methods which are not often used. With oxygen cutting a narrow and parallel gap is obtainable. The heat affectea zone is on the other hand very wide and causes strong distribution of the workpiece. Plasma cutting results in a somewhat broader and tempering gap. The heat-affected zone is relatively narrow and only causes insignificant distortion. By laser cutting a very narrow gap is obtained. The heat-affected zone is so narrow that no measurable distortion of the workpiece takes place. When cutting most types of plastics with both carbon dioxide laser and waterjet it is possible to obtain a very narrow parallel gap as well as a very 
smooth surface. With water cutting it is the ultimate strength of the material which influences the quality of the cut.

\section{4}

Anderson, A.W., Army Toxic and Hazardous Materials Agency, Aberdeen, MD; U.S. Department of Energy, Assistant Secretary for Nuclear Energy, Office of Remedial Action and Waste Technology, Washington, DC

\section{Department of the Army Installation Restoration Program}

CONF-8810239; Proceedings of the U.S. Department of Energy Remedial Action Program Annual Meeting, Gaithersburg, MD, October 18-20, 1988, 555 pp.; (pp. 2.45-2.62) (1988)

The Army's Installation Restoration Program (IRP) was established in 1975 in response to regulatory action at several installations where past disposal practices had caused contamination of streams and groundwater. The neud to decontaminate excess Army-owned real estate also was considered in early IRP activities. A variety of site types have been discovered on Army installations. The major site types evaluated to date include: contaminated soil areas, landfills, lagoons, buildings, burning grounds, sumps, pits, storage tanks, sewage treatment plants, storage pads, industrial wastewater treatment plants, and salvage yards. Tweniy Army installations have been proposed for or listed on the National Priorities List (NPL). The need for taking action at hazardous waste sites, huwever, is based on threats they pose to human health, welfare or the environment. Sites do not have to be on the NPL in order to be cleaned up through IRP activities. All of the sites that caused Army installations to be proposed for the NPL are being evaluated and cleaned up. In addition, all Army properties have been or will be assessed and where needed they will be addressed by the IRP.

\section{5}

Anttila, M., F. Wasastjerna, and T. Vieno, Voimayhtiociden Ydinjactetoimikunta, Helsinki, Finland
Activity Inventory of the Activated Decommissioning Waste of the Loviisa Nuclear Power Plant

YJT-89-02; 84 pp. (1989, May)

The estimate of the activity inventory of the activated decnmmissioning waste of the Loviisa nuclear power plant has been updated. The irradiation fluxes have been calculated in the radial and axial direction. The activation and subsequent cooling of the decommissioning waste components have been analyzed with the ORIGEN-S and ORIGEN-2 computer programs using new flux values. In the radial direction the region studied has been extended to the outer surface of the biological shield and in the axial direction the components about $1 \mathrm{~m}$ below or above the fuel region have been included in the caiculations. The lifetime of the power plant has been assumed to be 35 annual cycles with a load factor of $85 \%$. The results are presented as tables as well as ligures, which give, besides the total activity of the components in question, the contribution of the most important nuclides. The new values do not differ appreciably from the previous ones. The so called shicld elements contain a great part of the activity inventory. In case of the biological shield, one should take into account the rather high activities of $\mathrm{Cl}-36, \mathrm{Ar}-39$, and $\mathrm{Ca}-41$.

\section{6}

Astall, M., and R.G.G. Holmes, British Nuclear Fuels, Limited, Scllafield, Cumbria, United Kingdom

Development of Bagless Transfer Systems at British Nuclear Fuels Limited (BNFL)

CONF-880201; Waste Management '88: Waste Processing, Transportation, Storage and Disposal - Technical Programs and Public Education, Post, R.G. (ed.), Proceedings of a Conference, Tucson, AZ, February 26-March 3, 1988, Vol. 1, 1049 pp.; (pp. 509-514) (1988)

Bagless transfer systems can be used to reduce much of the large volume of plutonium-contaminated material that arises during glove box operations and can be used to fill and close large containers of waste (drums) while maintaining an uncontaminated 
surface. The authors aim to present the results of development on a large bagless transfer system (18 in. dia) that can be used in conjunction with a range of drum sizes. In addition they discuss experience with a small bagless transfer system (6 in. and 8 in. dia) that operates on the purged port principle. This unit can be used to transfer items between active facilities and results in a much lower exposure of operators to airborne contamination than by conven:ional bagging systems.

\section{7}

Bach, F.W., H. Steiner, and G. Pilot

Analysis of Results Obtained with Different Cutting Techniques and Associated Filtration Systemus for the Dismantling of Radioactive Metallic Components

CONF-891077; Decommissioning of Nuclear Installations, Proceedings of the 1989 International Symposium, Brussels, Belgium, October 24-27, 1989. Commission of the European Community, Brussels, Belgium; 18 pp. (1989)

The present joint study performed by Commissariat a l'Energie Atomique and University of Hanover and coordinated by the CEC was intended to analyze the results generated in a number of research contracts concerned with cutting tests in air and under water, under consideration of the prevailing working conditions. The analysis has led to a large data base, giving broadly accessed intormation for the dismantling of radioactive components. The study was enlarged, where possible, to a broader scope including also recently obtained results outside the present research program, considering also supplementary cutting tools and filtration systems not covered by the present program. Data was concentrated in structured information packages on practical experience available for a series of cutting tools filters. These were introduced into a computerized user-friendly data-bank, to be considered as a first stage development, which should be continuously updated and possibly oriented in the future to an expert system.
58

Bailey, G., United Kingdom Atomic Energy Authority, Harwell Laboratory, Harwell, United Kingdom

The Refurbishment of the D1206 Fuel Reprocessing Plant

Decommissioning of Nuclear Facilities, Proceedings of an International Seminar, London, United Kingdom, July 6-7, 1988; (18 pp.) (1988, July 7)

The fast reactor fuel reprocessing facility at Dounreay is described. The modifications were necessary for improved plutonium handling. Extensive radiation decontamination was necessary.

\section{9}

Baliko, R., F. Stercz, J. Klockner, J. Luer, D. Borchardt, and H. Krohn, Siemens AG, Offenbach, Federal Republic of Germany

\section{BER II - Dismantling and Conditioning}

Atomwirtschaft, Atomtechnik 34(2):94-97 (1989, February)

Neutron beam scattering experiments are an indispensable and, in many investigations, unique tool employed in research and training in solid state physics and materials science, two of the main activities of the Hahn-Meitner Institute in Berlin (HMI). As a result of a number of measures taken, the expansion of the Berlin BER II experimental reactor has resulted in a higher power level and an increased available neutron flux. Prior to the expansion, the activated pool internals were dismantled and packaged and conditioned ready for repository storage. The interfaces for the new installation were made at the same time.

\section{$6 C$}

Barkatt, A., R. Adiga, M.A. Adel-Hadadi, A. Barkatt, X. Feng, S.M. Finger, and W. Sousanpour, Catholic University of America, Vitrcous State Laboratory, Washington, DC 
Development of QC and Predictive Leach Tests for West Valley Glasses

CONF-880201; Waste Management '88: Waste Processing, Transportation, Storage and Disposal - Technical Programs and Public Education, Post, R.G. (ed.), Proceedings of a Conference, Tucson, AZ, February 26-March 3, 1988, Vol. 2, 1052 pp.; (pp. 473-481) (1988)

Two types of leach tests have been developed for the characterization of the chemical durability of nuclear waste glasses. A pulsed-flow test has been evaluated for applicability at long residence times, using $\mathrm{S} / \mathrm{V}$ scaling, for ability to distinguish between more durable and less durable glasses in the long term, for applicability in the presence of ground water and canister materials, and for compatibility with observations on natural analog systems. A quick, simple, and highly reducible static test procedure has been evaluated as a tool for screening glass compositions according to chenical durability by comparing its results with those of the pulsed-flow test.

61

Barnes, S.M., J.M. Pope, and C.C. Chapman, West Valley Nuclear Services Company, Inc., West Valley, NY; Pacific Northwest Laboratory, Richland, WA

Three Year's Progress of the West Valley Demonstration Project Vitrification System

CONF-880201; Waste Management '88: Waste Processing, Transportation, Storage and Disposal - Technical Programs and Public Education, Post, R.G. (ed.), Proceedings of a Conference, Tucson, AZ, February 26-March 3, 1988, Vol. 2, 1052 pp.; (pp. 195-202) (1988)

The vitrification equipment designed to solidify the high-level wastes stored at the Western New York Nuclear Service Center has been installed in a cold testing facility at the site. This system has been undergoing checkout and performance testing for approximately three years. This report provides a description of the reference vitrification flow sheet and the process equipment, and summarizes integrated equipment testing completed since the
October, 1986, simulated waste slurry processing tests. 'Through July 1987, 107,50 liters of simulated waste have been vitrified and $68,100 \mathrm{~kg}$ of simulated waste glass have been produced. To qualify the process and the resulting product, a reliable, operating system must first be established. At the time of this writing, most of the equipment has been upgraded or modified and is supporting this requirement.

62

Bejder, B.D., M.V. Tkachev, V.S. Rozhnov, A.A. Budakov, and I.M. Shevchuk, Gosudarstvennyj Komitet po Ispol'zovaniyu Atomnoj Ehnergii SSSR, Tsentral'nyj Nauchno-Issledovatel'skij Institut Informatsii i, Moscow, USSR

\section{Installation for Semiautomatic Air-Plasma Metal Cutting Up to $6 \mathrm{~mm}$ Thickness}

INIS-SU-95; (pp. 31-32) (1988)

SA401M2 installation for semiautomatic air-plasma cutting is described. Results of metallographic investigations and gas analysis of cutting edges of low-carbon steel are presented. It is shown that SA401M2 installation provides separation of metal up to $6 \mathrm{~mm}$ thickness at 45-85A current when nozzle is resting on a sample.

63

Bell, M.J.

\section{Materials Licensec Financial Assurance Guidance Related to Decommissioning: Availability}

Federal Register 54(171):37063 (1989, September 6)

The Nuclear Regulatory Commission (NRC) has published "Standard Format and Content for Financial Assurance Mechanisms Required for Decommissioning Under 10 CFR parts 30, 40, 70 and $72^{\text {" }}$ and "Standard Review Plan for the Review of Financial Assurance Mechanisms for Decommissioning Under 10 CFR parts 30, 40, 70 and 72." The first discusses the information to be provided in a materials license application and establishes a uniform format for presenting the 
information required to meet the decommissioning licensing requirements. The second is prepared for the guidance of NRC staff reviewers in performing reviews of applications from materials licensees.

64

Bergman, C., National Institute of Radiation Protection, Stockholm, Sweden

\section{Decommissioning Nuclear Power Plants: Authority and Policy Issucs}

SSI-88-08; 11 pp. (1988, April 18)

The present laws provide authorities with control of all aspects of radiological protection and safety in connection with decommissioning of nuclear power plants. However a law modification is needed if an earlier action than 2010 is claimed. Several reasons speak for decommissioning in close connection to reactor closing. Before any steps are taken it is however necessary to have an ultimate storage in operation for decommissioning wastes. Although there is today technique available that is sufficiently well established for decommissioning nuclear power plants, there are still reasons to adapt it to the specific Swedish circumstances. Also in other fields there are reasons for research and development.

65

Bishop, A.

Ventilation and Filtration Techniques for Handling Aerosols Produced by Thermal Cutting Operations

CONF-891077; Decommissioning of Nuclear Installations, Proceedings of the 1989 International Symposium, Brussels, Belgium, October 24-27, 1989. Commission of the European Community, Brussels, Belgium; (pp. 572-581) (1989)

The decommissioning of nuclear installations using thermal cutting techniques in air has been shown to generate considerable amounts of aerosol that shorten the working life of filters in a ventilation system. A program of work was initiated to characterize the aerosols from different thermal cutting operations. Suitable ventilation and filtration systems were developed and assessed in an inactive environment for use in a radioactive, semi remote decommissioning operation. The results of the work program are repeated. When decommissioning a radioactive facility, different materials and composites have to be cut up. In the Windscale Advanced Gas-Cooled Reactor (WAGR) Decommissioning Project thermal processes will be used wherever possible to cut the materials. The main process is oxypropane cutting. To minimize absolute filter consumption prefilters are required to extract large fraction of the aerosol, particularly sub-micron, produced by thermal cutting operations. A work program was undertaken to categorize the aerosols, select and test suitable prefilters and specify a suitable system to minimize secondary waste and operator exposure. Cutting was done on nonradioactive stecl samples.

\section{6}

Bizyacv, Y.S., and V.M. Tarasov

Main Approaches to NPP Decommissioning and to the Radioactive Waste Problem to be Solved in France

Energeticheskoe Stroitel'stvo za Rubezhom 4:13-17 (1989, August)

Main trends in theoretical investigations and practical designs necessary when solving a set of problems related to nuclear power plant decommissioning are elucidated. Great attention is paid to the policy in the field of radioactive waste managenent in France.

67

Boorman, T., United Kingdom Atomic Energy Authority, Harwell Laboratory, Harwell, United Kingdom

Planning and Progress of the WAGR Decommissioning Project

Decommissioning of Nuclear Facilitics, Procecdings of an International Seminar, London, United Kingdom, July 6-7, 1988; (13 pp.) (1988, July 7) 
The United Kingdom Atomic Energy Authority (UKAEA), as Britain's nuclear R\&D organization, has designed, built, and operated a number of prototype nuclear power plants. Anticipating the UK's likely nuclear decommissioning needs towards the end of the century, the UKAEA in 1975 initiated preliminary decommissioning studies on one of these - the Windscale Advanced Gas-Cooled Reactor (WAGR). This was followed in November 1981 by the decision to decommission WAGR to Stage 3 , the "green-ficld" stage.

\section{8}

Borisch, R.R., D.E. Carl, and D.R. Leap, West Valley Nuclear Services Company, Inc., West Valley, NY

Construction and Cold Testing of the West Valley Supernatant Treatment System

CONF-880201; Waste Management '88: Waste Processing, Transportation, Storage and Disposal - Technical Programs and Public Education, Post, R.G. (ed.), Proceedings of a Conference, Tucson, AZ, February 26-March 3, 1988, Vol. 2, 1052 pp.; (pp. 831-836) (1988)

The primary objective of the West Valley Demonstration Project (WVDP) is to solidify 2120 cu $\mathrm{m}$ (560000 gallons) of high level liquid waste and the transport it to a federal repository. A secondary goal of the project is to utilize existing plant facilities to the maximum extent project in order to prove decontamination and decommissioning technology. The supernatant treatment system (STS) has been designed to pretreat the supernatant liquid portion of the high-level waste. The STS will be used to strip cesium-137 from the liquid, making it low-level waste. The resulting low-level liquid waste will be volume reduced through the process of evaporation. The remaining low-level waste concentrate will be solidified in cement and stored on-site. The authors describe the design history, general process flow shect, construction, and cold testing of the STS.

69

Bosnak, R.

Draft Regulatory wuides: Issuance and Availability
Federal Register 54(192):41190-41191 (1989, October 5)

The Nuclear Regulatory Commission (NRC) has issued for public comment drafts of two new guides planned for its Regulatory Guide Series. This series has been developed to describe and make available to the public such information as methods acceptable to the NRC staff for implementing specific parts of the Commission's regulations, techniques used by the staff in evaluating specific problems or postulated accidents, and data needed by the staff in its reviews of applications for permits and licenses.

\section{0}

Bradbury, D., Bradtec, Pencot, and Tresham, Wotton-Under-Edge, United Kingdom

Facing the Next Hurdle: Dealing with Decommissioning Wastes (Decontamination)

Nuclear Engineering International 34(420):39-40 (1989, July)

The technology of decontamination has become quite sophisticated, with techniques available to deal with most problems, but public acceptance is still an obstacle to be overcome.

\section{1}

Bramlitt, E.T., Defense Nuclear Agency, Kirtland Air Force Base, NM

\section{Plutonium Mining for Cleanup}

Health Physics 55(2):451-453; Radiation Protection - A Look to the Future, Proceedings of the 25th Hanford Life Sciences Symposium, Richland, WA, October 21-23, 1986; (3 pp.) (1988, August)

Cleanup is the act of making a contaminated site relatively free of plutonium so it may be used without radiological safety restrictions. Contaminated ground is the focus of major cleanups. Cleanup traditionally involves determining plutonium content of soil, digging up soil in which radioactivity exceeds guidclines, and relocating excised soil to a waste-disposal site. Alternative technologies have been tested at Johnston Atoll (JA), where there is as 
much as $100,000 \mathrm{cu} \mathrm{m}$ of plutonium-contaminated soil. A mining pilot plant operated for the first 6 months of 1986 and made $98 \%$ of soil tested "clean", from more than $40 \mathrm{kBq} / \mathrm{kg}(1000 \mathrm{pCi} / \mathrm{g})$ to less than about $500 \mathrm{~Bq} / \mathrm{kg}(15 \mathrm{pCi} / \mathrm{g})$ by concentrating plutonium in $2 \%$ of the soil. The pilot plant is now installed at the U.S. Department of Energy Nevada Test Site for evaluating cleanup of other contaminated soils and refining cleanup effectiveness. A full-scale cleanup plant has been programmed for JA in 1988. In this paper, previous cleanups are reviewed, and the mining endeavor at JA is detailed. "True soil cleanup" is contrasted with the classical "soil relocation cleanup." The mining technology used for plutonium cleanup has been in use for more than a century. Mining for cleanup, however, is unique. It is envisioned as being prominent for radiological and other cleanups in the future.

72

Brant, A.W., Wastechem, Bramhall, United Kingdom

Why It Is Important Not to Get too Carricd Away with the Technology (Reactor Decommissioning)

Nuclear Engineering International 34(420):30-31 (1989, July)

Purchase of a specialist piece of equipment can make economic sense if it leads to an overall reduction in time and costs. However, people are still the most cost-effective way of carrying out many operations, particularly in view of the sensory feedback that they can provide, which is absent in so many automatic systems. This point of view is discussed for reactor dismantling.

73

Brighenti, G., B. Camiscioni, and G. Chessa, Ente Nazionale per l'Energia Elettrica, Rome, Italy

Dismantling the RB-2 Rescarch Reactor: An Application of a Radiation Protection Approach Relevant to Italy's Decommissioning Methodology
Nuclear Technology 86(2):128-135 (1989)

The RB-2 research reactor was operated for 17 years at power levels of the order of $10 \mathrm{~kW}(1963-1969)$ and $100 \mathrm{~W}$ (1971-1980). During dismantling, the radiological risk for personnel was recognizably low, but radioactivity levels associated with the waste materials and the site itself needed to be evaluated. Predismantling activities consisted of a preliminary radiological characterization, including direct measurements, spectrometric analyses of samples, and theoretical calculations. Determination of "nonradioactive" limits determined the disposition of the site and the transportation routes for the waste materials. After dismantling, the site was extensively monitored for remaining radioactivity. In general, unrestricted release has been achievable for the site; only a small area is still subject to radiological control.

74

Brown, G.Â., Central Electricity Generating Board, London, United Kingdom

Starting to Dismantle Berkeley (Reactor Decommissioning)

Nuclear Enginecring International 34(420):23-24 (1989, July)

The United Kingdom Central Electricity Generating Board anticipates a continuous program of Magnox decommissioning over the next 20 years, with Stage 2 at the shutdown Berkeley station being achicved in around 10 years time.

75

Buck, S., and A. Colquhoun

Decommissioning of a Mixed Oxide Fucl Fabricating Facility

CONF-891077; Decommissioning of Nuclear Installations, Proceedings of the 1989 International Symposium, Brussels, Belgium, October 24-27, 1989. Commission of the European Community, Brussels, Belgium; (pp. 713-722) (1989) 
Decommissioning of the Coprecipitation Plant, which made plutonium/uranium oxide fucl, is a lead project in the British Nuclear Fucls, Limited Sellaficld decommissioning program. The overall program has the objectives of gaining data and experience in a wide range of decommissioning operations, and hence, in this project to pilot the decommissioning of a plant heavily contaminated with plutonium and other actinides. Consequently the operations have been used to test improvements in temporary containment, contamination control and decontamination methods and to develop in situ Plutonium Assay, Plutonium Recovery and Size Reduction methods. Finally the project is also yiclding data on manpower requirements, radiation uptake and waste arisings to help in the planning of future decommissioning projects.

76

Chapuis, A.M., G. Gouvras, and F. Luykx, Commissariat a l'Energie Atomique, Centre d'Etudes Nucleaires de Fontenay-aux-Roses, Institute de Protection et de Surete Nucleaire, Fontenay-aux-Roses, France

Radiological Protection Criteria for the Recycling of Matcrials from the Dismantling of Nuclear Installations Communities, Luxembourg (Luxembourg)

CONF-880404; Proceedings of an International Radiation Protection Association Congress, Sydney, Australia, April 10, 1988; (pp. 1227-1230) (1988)

A considerable fraction of the materials used in the construction of nuclear installations will, on decommissioning and dismantling, be only lightly active or contaminated. These materials could have high economic value and this provides an incentive for recycling or reuse. The recycling of matcrials from the dismantling of nuclear installations, either as scrap or as discrete items, would require them to follow conventional processing and marketing procedures which do not provide for further radiological control. Since numerous installations are reaching the end of their working life, and since large quantities of such scrap and items circulate between the various countries, the radiological problems of recycling would have to be resolved on an international scalc.

77

Chapuis, A.M., and F. Luykx

Radiological Criteria for Unrestricted Release of Materials from Nuclear Installations

CONF-891077; Decommissioning of Nuclear Installations, Proceedings of the 1989 International Symposium, Brussels, Belgium, October 24-27, 1989. Commission of the European Community, Brussels, Belgium; (pp. 85-93) (1989)

It is widely accepted that materials very slightly radioactive may be released to the environment without further control if this practice can be justified and if the corresponding risk to the exposed individuals can be regarded as trivial. Risk levels of the order of $10(E+16)$ per year may be so regarded and they correspond to an annual effective dose of the order of $100 \mathrm{mSv} / \mathrm{year}$. This exemption level of dose, although conceptually simple, is very difficult to apply in practice in order to determine the sources and practices which may actually be exempted from regulatory control. For this reason, derived levels, expressed in activity terms, have to be set. They can be established on the basis of the characteristics of the radionuclides present and the possible exposure pathways. There are two main routes of unrestricted release of radioactive materials, namely recycling and disposal. The option to be preferred in each case would mostly depend on the associated economic advantage that it offers. One would expect the recycling option to be readily selected in the case of metals, the most important of which is steel. Disposal would normally apply to materials of little or no value such as concretc, rubble or insulating materials.

78

Charamathicu, M.A., Societe des Travaux en Milicu Ionisant, Git-sur-Yvette, France

Experience in the Decontamination and Dismantling of Alpha Facilitics 
Decommissioning of Nuclear Facilitics, Proceedings of an International Seminar, London, United Kingdom, July 6-7, 1988; (10 pp.) (1988, July 7)

The author gives some details of STMI's experience of alpha contaminated radiochemical-installation dismantling. STMI has been involved in nearly all of the alpha decontamination projects undertaken in France over the last ten years. The accumulated experience represents a considerable technical capital which is being added to as the years go by and as ever-new problems are dealt with.

79

Chung, H.M., Argonne National Laboratory, Argonne, IL

\section{Thermal Aging of Some Decommissioned Reactor Components and Methodology for Life Prediction}

CONF-8907137; Plant Lile Extension for Nuclear Components, Procecdings of a Symposium, Honolulu, HI, July 24-27, 1989; (45 pp.) (1989, March)

Since a realistic aging of cast stainless stcel components for end-of-life or life-extension conditions cannot be produced, it is customary to simulate the thermal aging embrittlement by accelerated aging at approximately $400 \mathrm{deg}$ C. In this investigation, field components obtained from decommissioned reactors have been examined after service up to 22 years to provide a benchmark of the laboratory simulation. The primary and secondary aging processes were found to be identical to those of the laboratory-aged specimens, and the kinetic characteristics were also similar. The extent of the aging embrittlement processes and other key factors that are known to influence the embrittlement kinetics have been compared for the decommissioned reactor components and materials aged under accelerated conditions. On the basis of the study, a mechanistic understanding of the causes of the complex behavior in kinctics and activation energy of aging (i.e., the temperature dependence of aging embrittlement between the accelerated and reactor-operating conditions) is presented. A mechanistic correlation developed thereon is compared with a number of available empirical correlations to provide an insight for development of a better methodology of life prediction of the reactor components.

\section{0}

Clifton, J.R., and L.I. Knab, National Institute of Standards and Technology, Gaithersburg, MD

\section{Service Life of Concrete}

NUREG/CR-5466; NISTIR-89-4086; 92 pp. (1989, November)

The U.S. Nuclear Regulatory Commission (NRC) has the responsibility for developing a strategy for the disposal of low-level radioactive waste (LLW). An approach being considered for disposal is to place the waste forms in concrete vaults buried in the earth. A service life of 500 years is required for the concrete vaults as they may be left unattended for much of their lives. This report examines the basis for making scrvice life predictions based on accelerated testing and mathematical modeling of factors controlling the durability of concrete buried in the ground. Degradation processes are analyzed based on accelerated testing and mathematical modeling of factors controlling the durability of concrete buried in the ground. Degradation processes are analyzed based on considerations of their occurrence, extent of potential damage, and mechanisms. A recommended research plan for developing methods for predicting the service life of concrete is presented. The major degradation processes that concrete of underground vaults will likely encounter are sulfate attack, corrosion of reinforcing stecl, alkali-aggregatc reactions, and lcaching by ground water. Freczing and thawing damage could occur before before the vaults are covered with soll and therefore are addressed. Other degradation processes which may occur are microbiological attack, salt crystallization, and attack by LLW, especially by acidic materials. Two important factors controlling the resistance of concrete to these degradation processes are its quality and permeability. Concepts of quality and factors affecting quality of concrete are discussed. Permcability is discussed in terms of the water-to-cement ratio, the pore structure of eoncrete, and the effects of cracks. 
81

Colquhoun, A., British Nuclear Fucls, Limited, Sellafield, Cumbria, United Kingdom

\section{Decommissioning in British Nuclear Fucls PLC}

Decommissioning of Nuclear Facilities, Procecedings of an International Seminar, London, United Kingdom, July 6-7, 1988; (9 pp.) (1988, July 7)

The decommissioning methods developed by British Nuclear Fucls, Limited at the Sellaficld site are discussed.

\section{2}

Commission of the European Communities, Joint Development Center, Brussels, Belgium

\section{Radioactive Waste Focus}

Radioactive haste Focus SP.I-89.44(11):1-11 (1989, December)

The European Community's research programs on "Decommissioning of Nuclear Installations" are aimed at developing effective techniques and procedures for decommissioning; the main objective is to strengthen the scientific and technical basis of decommissioning with particular attention to safety and radiological protection. This journal is a periodic information leaflet on the activities of the European Community in the ficld of radioactive waste management. This particular issue features : overview of rescarch into decommissioning of nuclear installations supported by the community, including: long-term integrity of buildings and systems; decontamination for decommissioning purposes; dismantling techniques; waste treatment of stecl, concrete, and graphitc; large waste containers; cstimation of quantities of radioactive waste from decommissioning activities; influence of plant design features on decommissioning; and the testing of new decommissioning techniques under real conditions. The journal also notes new publications, reviews program management, highlights research achievements, summarizes past meetings, seminars, and conferences, and lists upcoming events.
83

Commission of the European Communities, Luxembourg, Luxembourg

The Community's Rescarch and Development Program on Radioactive Waste Management and Storage, Shared Cost Action - Nuclear Science and Technology Serics: Annual Progress Report

EUR-11482; 645 pp. (1989)

This is the second Annual Progress Report of the European Community's 1985-1989 program of research on radioactive waste management and disposal, carried out by public organizations and private firms in the community under cost-sharing contracts with the Commission of the European Communities. The Council of the Ministers of the European Communities adopted the program in March 1985 (1), considering: "The use of nuclear energy incvitably involves the production of radioactive waste; it is therefore essential to implement effective solutions to guarantec the safety and protection of man and the environment against the potential risks associated with the management of such vaste." The Council also recognized that the 1980-1984 program of research on radioactive waste management and disposal, which was the second of its kind, "has enabled a large amount of information to be obtained which it is advisable to complete and validate by the implementation or research, development and demonstration action, representing the real waste management and disposal conditions which can be expected in the future." The 1985-1989 program is therefore aiming at perfecting and demonstrating a system for managing the radioactive waste produced by the nuclear industry, ensuring, at the various stages, the best possible protection of man and the crivironment; its contents are as follows: (1) Waste Management Studics and R \& D Actions, and (2) Construction and/or Opcration of Underground Facilities Open to Community Joint Activities. The commission's participation to the cost of the prograni amounts to 62 Million ECU for its five year duration. The Commission is responsible for managing the program. In this task, the Commission is being assisted by the Management and $\mathrm{Co}$-ordination Advisory Committec "Nuclear Fission Encrgy - Fucl Cycle/Waste Processing and Disposal." At the beginning of the 1985-1989 program, the Commission issucd a first call for 
research proposals. Over 250 research proposals have been recelved at the closing date, surpassing in total seven times the available budget, and only a fraction thereof could be accepted for negotiation. A second call for research proposals has been issued in 1986 with over 160 proposals being recelved. A total of 146 contracts have been signed as of $12 / 31 / 1987$. This report describes the work to be carried out under the research contracts already concluded before the end of 1987, as well as the work performed and the results obtained.

84

Conn, A.F., Tracor Hydronautics, Inc., Laurel, $\mathrm{MD}$

\section{Rapid Cutting of Pavement with Cavitating Water Jets}

Jet Cutting Technology, Proceedings of the Eighth International Symposium, Duram, England, September 9-11; 1986; (pp. 231-240) (1986)

A field trial of the cavitating water jet method has demonstrated that substantial tine and cost savings may potentially be gained with this new approach, relative to either conventional pavement cutting methods such as diamond saws or pncumatic pavement breakers, or a $241 \mathrm{MPa}(350()) \mathrm{psi}$ ) abrasive water jet. In this preliminary trial, a cavitating jet nozzle, operating at $69 \mathrm{MPa}(1000)$ psi), cut through pavement 24 to $34 \mathrm{~cm}$ thick at rates of over $23 \mathrm{~cm} / \mathrm{min}$. Using a cavitating water jet system, the estimated cost to cut a 0.6 by 1.2 meter perimeter slot in $20 \mathrm{~cm}$ thick pavement was $\$ 18.70$ per hole. In comparison, the average cost for conventional methods was $\$ 42.47$ per hole; and $\$ 35.17$ for an abrasive jet. A prototype unit, capable of cutting circular holes up to $1.2 \mathrm{~m}$ in diameter in pavement is now being developed.

85

Cotter, B.P.

Northern States Power Company: Designation of Presiding Officer

Federal Register 54(199):42607 (1989, October 17)
A single member of the Atomic Salcty and Licensing Board Pancl is hereby designated to rule on petitions for leave to intervene and/or requests for hearing and, if necessary, to serve as the presiding officer to conduct the hearing in the event that an informal adjudicatory hearing is ordered in the following Materials Licensing procecding. Following consultation with the Pancl Chairman, pursuant to the provisions of 10 CFR 2.722, the Presiding Officer has appointed Administrative Judge Jerry R. Kline to assist the Presiding Officer in taking evidence and in preparing a suitable record for review.

\section{6}

Dalzicl, S.P.C., British Broadcasting Corporation, London, United Kingdom

Chernobyl: Recovery Operations and the Entombment of Reactor 4

Decommissioning of Nuclear Facilitics, Procecdings of an International Seminar, London, United Kingdom, July 6-7, 1988; (8 pp.) (1988, July 7)

The author describes the measures taken by the Soviet authorities following the Chernobyl accident, from putting out the fire to the final entombment.

\section{7}

Damerow, M.W., West Valley Nuclear Services Company, Inc., West Valley, NY

\section{West Valley Demonstration Project Community Relations Plan FY 1990/91}

DOE/NE/44139-59; 16 pp. (1989, September)

The purpose of the Community Relations Plan is to fully inform the community about the West Valley Demonstration Project (WVDP) and provide opportunities for public input. A sound approach to community relations is essential to the creation and maintenance of public awareness and community support. The WVDP is a matter of considerable public interest because it deals with nuclear waste. The mission of the WVDP is to solve an existing environmental concern by solidifying high-level radioactive waste and transporting the solidified waste to a federal repository for permanent disposal. 
The public requires evidence of the continued commitment and demonstrated progress of the industry and the government in carrying out the mission in order to sustain confldence that the WVDP is being managed well and will be successfully completed. For this reason, a comprehensive communication plan is essential for the successful completion of the WVDP. In addition, in 1988 the WVDP intiated development of an Environmerital Impact Statement (EIS). The ElS will provide environmental information for consideration in federal and state decision-making related to the WVDP completion activities by DOE and state decision-making on final closure of the Western New York Nuclear Service Center (the Conter) by New York State Energy Research and Development Authority, A strong community relations plan is necessary to facilitate public participation in the EIS process.

\section{8}

Danchenko, M.E., E.O. Paton Welding Institute, Kiev, Ukrainian SSR, USSR

\section{Underwater Arc Cutting with a Cored Electrode}

Welding International 3(7):562-563 (1989)

The author presents a method of underwater arc cutting with a cored clectrode, which is based on the continuous supply into the arcing zone of a special cored clectrode whose core contains gas-forming and arc-stabilizing components. Analysis of the special fealures indicates that this is one of the most promising methods of semiautomatic underwater culting.

\section{9}

\section{Decommissioning of a Nuclear Power Plant}

Umwelt- und Planungsrecht 10(3):119-120 (1990), March)

From the head notes of a court decision: Responsibility for definition and evaluation of risk lies with the supervisory authority, and this applies to the licensing procedure, the procedure for revocation, and the procedure for decommissioning. If the court considers the material available for rislk evaluation to be sufficiently conservative and free from inappropriate considerations, there is, at least in summary proceedings, no need for examining opinions to the contrary, even if placed on a scientific basis. A court that has to deal with a matter of decommissioning may not take into account considerations that are contrary to the purpose pursued by the supervisory authority in agrecment with Section 1, No, 1 of the Alomic Energy Act, to foster the peaceful uses of nuclear encrgy, if such considerations are intended to launch a decision for abandonment of nuclear power; the court may not have recourse to a "safety philosophy" that forms the background of such considerations.

\section{0}

Delene, J.G., and C.R. Hudson, Jr., Oak Ridge National Laboratory, Oak Ridge, TN

\section{Cost Estimate Guidelines for Advanced Nuclear Power Technologies}

ORNL/TM-10071/R2; 160 pp. (1990, March)

To make comparative assessments of competing technologies, consistent ground ruies must be applied when developing cost estimates. This document provides a uniform set of assumptions, ground rules, and requirements that can be used in developing cost estimates for advanced nuclear power technologies.

\section{1}

Dicrcks, D.R., Argonne National Laboratory, Materials and Components Technology Division, Argonne, IL

\section{Effect of Decontamination on Aging Processes and Considerations for Life Extension}

Nuclear Engineering 115(2-3):207-218; Proceedings of the 15 th Water Reactor Safety Information Meeting, Gaithersburg, MD, October 26-29, 1987; (pp. 207-218) (1989, July)

The basis for a recently initiated program on the chemical decontamination of nuclear reactor components and the possible impact of decontamination on extended-life service is described. The incentives for extending life beyond the present 40-year limit are discussed, and the possible aging degradation processes that may be accentuated in extended-life service are summarized. Chemical 
decontamination processes for nuclear plant primary systems are reviewed with respect to their corrosive effects on structural alloys, particularly those in the aged condition. Avallable experience with chemical cleaning processes for the secondary side of pressurized water reactor (PWR) stcam generators is also considered. Overall, no severe materials corrosion problems have been found that would preclude the use of these chemical processes, but concerns are raised with respect to corrosion-related problems that may develop during extended service.

\section{2}

Distenfeld, C.H., B. Brosey, and H. Igarashi, Bechtel National, Inc., Middletown, PA

\section{A Fast-Sorting Measurement Technique to Determine Decontamination Priority}

Transactions of the American Nuclcar Socicty 57:458; Nuclear Fission, Procecdings of the 1988 International Conference, Washington, DC, October 30-November 4, 1988 (1988)

Recovery of large contaminated buildings, such as the Three Mile Island Unit 2 (TMI-2) reactor building, are complicated by ccilings that can be 12 to $13 \mathrm{~m}$ high. Much of the overhead space is filled with conduits, pipes, cable trays, ventilation ducts, and steel structures. To conserve radiation exposure of recovery personnel, it is important to prioritize the effort so that early work provides maximum exposure reduction. Subsequent exposure reduction can then be carried out with less total exposure to recovery personnel. This favorable scenario depends on identification of key surfaces that most affect the exposure rate. Two related approaches were considered: (1) directional scasurements with a high angular resolution detector and (2) directional measurements with low angular resolution detectors.

93

Draulans, J.

The Decommissioning of Large and Complex Glove Box Structures in a Mixed Oxide Fuel Fabrication Plant

CONF-891077; Decommissioning of Nuclear Installations, Procecdings of the 1989
International Symposium, Brussels, Bclgium, October 24-27, 1989. Commission of the European Community, Brussels, Belgium; (pp. 620-628) (1989)

The information is given concerning the different techniques applied during the decommissioning of glove boxes and equipment inside the BELGONUCLEAIRE Mixed Oxide Fucl fabrication plant. The techniques have been selected on the basis of the glove box dimensions, the capability of being removed out of the building and/or being transported on the public road, the inner contamination level, and etc. The wornout condition of equipment, the modifications in the process, the increase of capacity and the reduction of manual operation inside the glove boxes, necessitate the replacement of glove boxes and equipment in Mixed Oride fuel fabrication plants. These decommissioning and dismantling operations are nonroutine operations representing a scrious risk for a spread of radioactive contamination. This risk has to be reduced as much as possible. Different techniques have to be appliec depending upon the specific glove box characteristics.

\section{4}

Ebeling W., and K.W. Rose, Commission of the European Communities, Luxembourg, Luxembourg

Optimization of Filtering Systems for Various Concrete Decontamination Techniques

CONF-891077; Decommissioning of Nuclear Installations, Procecdings of the 1989 International Syrnposium, Brussels, Belgium, October 24-27, 1989. Commission of the European Community, Brussels, Belgium; 5 pp. (1989)

The effectiveness of mechanical and thermal methods for the decontamination of concrete surfaces has already been demonstrated. However, the collection and conditioning of the important amount of generated dust, acrosols and toxic gases needs further development. As concerns the filtration during thermal decontamination, multistage storing filters, as currently used in the nuclear industry, have shown adequate efficiency, but their limited storage capacity 
precludes an economic operation. Concerning the effectiveness of filtration systems for mechanical decontamination, no extensive investigations have been undertaken, so far. The aim of this research program is to investigate various filter systems, such as storage filters, regenerative mechanical filters, electrostatic filters, concerning their separation efficiency, their storage capacity and service life, including an analysis of the amount and size distribution of dust available at each filtering stage. The experiments will use dust generated by the above decontamination methrits on nonradioactive concrete samples. Based on existing data on radioactive concrete surfaces, a theoretical assessment on possible radioactivity inventories in the investigated filter systems will be made, with a view to their optimizaiion for real applications.

95

Ebeling, W., and K.W. Rose, Commission of the European Communities, Luxembourg, Luxembourg

Study and Optimization of Filter Systems for Separating Dusts and Aerosols Produced in Layers Concrete Decontamination

EUR-11995; 63 pp. (1989)

Whe ${ }_{\Perp}$ nuclear power plants finally shut down and are dismantled, contaminated surface layers of buildings must be removed, if it is not intended to dismantle and store the entire structure. The removal of the concrete in layers produces considerable amounts of dust and aerosols, which must be separated as completely as possible. The aim of the project was to find filter systems for economic separation of this dust. A literature study showed that cleanablc filters have advantages in comparison with other methods of separation. For this reason, three cleanable filters were investigated during the course of this research project in tests using inactive concrete samples. Separation levels of over $99.9 \%$ could be achieved with all tested filters. Furthermore, the effectiveness of one filter was demonstrated in decontamination operations. The manufacturers guarantee useful lives of 2000 operating hours for the tested filters. The costs of the separation of the dust are negligible in comparison with the expenditure for the removal of the concrete layers, the subsequent conditioning and the disposal.

96

Eidam, G.R., E.L. Tolman, J.M. Broughton, R.K. McCardell, and W.R. Stratton, Becintel Eastern Power Corporation, Three Mile Island Nuclear Station, Middletown, PA

\section{TMI-2 Defuelling Conditions and Summary of Research Findings}

Severe Accidents in Nuclear Power Plants, Proceedings of an International Symposium, Sorrento, Italy, March 21-25, 1988, Vol. 2, 722 pp.; (pp. 207-226) (1988, March 25)

The Three Mile Island Unit 2 accident was severe, with extensive melting of fuel, release of fission products, and relocation of a large quantity of molten fuel material onto the reactor vessel lower head. This molten material challenged the integrity of the reactor vessel, which remained intact. The post-accident condition of the plant presented an extremely difficult and complex plant recovery. Core defuelling necessitated the development and use of tools and the application of methods not used previously in the nuclear industry. During the past nine years, the TMI-2 accident has been a unique, invaluable source of information for improving and expanding the base of knowledge on severe accidents in power reactors. The authors present the plant's post-accident condition, summarize the primary results of research on progression of core damage and fission product behavior during the accident, and discuss the approach to defuelling the reactor.

97

Eisenstatt, L.R., and K.R. Routt, West Valley Nuclear Services Company, Inc., West Valley, NY

West Valiey Strategy for Production of a Qualified Waste Form

CONF-880201; Waste Management '88: Waste Processing, Transportation, Storage and Disposal - Technical Programs and Public Education, Post, R.G. (ed.), Proceedings of a Conference, 
Tucson, AZ, February 26-March 3, 1988, Vol. 2, 1052 pp.; (pp. 791-796) (1988)

The West Valley Demonstration Project will vitrify the high-level waste currently stored on site. A qualification testing strategy has been developed which will show that a product qualified for disposal will be generated. Process testing will use tracer studies that show how well-mixed the tanks are in the vitrification system. Glass testing will qualify a composition region to provide an operating range.

98

Electrical Power Research Institute, Palo Alto, CA

\section{Radionuclide Correlations at TMI-2 for 10 CFR 61 Compliance}

EPRI-NP-6454; 152 pp. (1989, August 15)

A detailed review and evaluation of all radionuclide analysis results from the TMI-2 waste has helped develop scaling factors for difficult-to-measure radionuclides. Analytic procedures and results from this research are applicable to waste classification for other sites involving higher-than-normal fuel leakage.

\section{9}

\section{Electropolishing Reduces Exposure Levels}

Nuclear Engineering International 34(416):17, 22-23 (1989, March)

A small U.S. company has developed two electropolishers specifically aimed at the nuclear industry. One is designed to cope with very large amounts of contaminants, while the other successfully avoids stripping the finish from irradiated components. Both systems reduce exposure levels.

\section{0}

Eremias, B., and M. Fresl, Statni Vyzkumny Ustav Ochrany Materialu G.V. Akimova, Praha, Czechoslovakia

Mechanism of Corrosion in Decontaminating Solutions of Stainless Steel and Highly Wear

\section{Resistant Hardfacing Alloys for a Liquid Metal Fast Breeder Reactor}

$$
\text { Jaderna Energie 34(5):176-179 (1988, May) }
$$

The authors summarize the important corrosion characteristics in decontaminating solutions of the cobalt-base, chromium-tungsten, hardfacing alloys and the AISI $316 \mathrm{~L}$ stainless steel on which they are welded. By knowledge of a mechanism of corrosion, the corrosion resistance of these alloys to localized corrosion in such solutions can be tailored to be comparable with the AISI $316 \mathrm{~L}$ stainless steel.

\section{1}

Erramuspe, H.J., Comision Nacional de Energia Atomica, Buenos Aires, Argentina

Construction Times and the Decommissioning of Nuclear Power Plants

CNEA-492; 27 pp. (1988)

The construction and the decommissioning periods of nuclear power plants (NPP), are studied, due to their importance in the generation costs. With reference to the construction periods of these plants, a review is made of the situation and technical improvements made in different countries, with the purpose of shortening them. In regard to the decommissioning of NPP, the present and future situations are reviewed in connection with different stages of decommissioning and their related prciulems, as the residual radioactivity of different components, and the size of the final wastes to be disposed of. The possibilities of plant life extensions are also revised in connection with these problems. Finally, the expected decommissioning costs are analyzed.

102

Feizollahi, F., R. Kohout, and A. Suzuki

Measurement and Sorting Techniques Qualified for Unrestricted Release of Metals from the Nuclcar Industry

CONF-891006; Proceedings of a Joint International Waste Management Conference, 
Kyoto, Japan, October 23-28, 1989, Vol. 1, 658 pp.; (pp. 397-400) (1989)

This report describes a low-level radioactivity controller (LLC) with a large detection surface area, used at a decommissioning site to sort parts weighing up to $500 \mathrm{~kg}$ as they move past the detectors. The device calculates the specific activity and the mean activity per unit area, while logging the measurement parameters and the number of parts scanned.

103

Fcizollahi, F., R. Kohout, and A. Suzuki

Evaluation of Contamination on Concrete of JPDR Building

CONF-891006; Proceedings of a Joint International Waste Management Conference, Kyoto, Japan, October 23-28, 1989, Vol. 1, 658 pp.; (pp. 183-188) (1989)

Decontamination of radioactive contaminated concrete in a nuclear facility is indispensable for reducing the amount of radioactive concrete waste and also for treating its building without any regulatory restriction when it is decommissioned. It is, therefore, necessary to estimate exactly the situation of radioactive contamination such as distribution and penetration depth of cortamination of concrete floors and walls in the builciings before demolition. In the Japan power demonstration reactor (JPDR), the situation of the contamination of the buildings was estimated by radioactivity measurement of concrete samples from the buildings before demolition. The results of the measurement are presented.

104

Feizollahi, F., R. Kohout, and A. Suzuki

Development of Electro-Honing Decontamination Technique

CONF-891006; Proceedings of a Joint International Waste Management Conference, Kyoto, Japan, October 23-28, 1989, Vol. 1, 658 pp.; (pp. 223-228) (1989)
In decontamination for decommissioning of nuclear power plants, the ability to discriminate between radioactivity and nonradioactivity levels must be pursued in order to reduce the total amount of radioactive waste. For this purpose, a new decontamination technique of high decontamination ability, electrohoning, has been developed. This report introduces remotely controlled equipment which automatically drives devices for decontaminating the wall surface of large reactor components (fuel pool, radioactive waste tank, etc.) using this electrohoning technique.

105

Feizollahi, F., R. Kohout, and A. Suzuki

Experience on Melting of Contaminated Steel Scrap and Treatment of Large Quantities of Low-Level Contaminated Steel for Unrestricted Release

CONF-891006; Proceedings of a Joint International Waste Management Conference, Kyoto, Japan, October 23-28, 1989, Vol. 1, 658 pp.; (pp. 437-440) (1989)

This paper presents the experience of a 1-year campaign of melting of steel scrap from the decommissioning of the Niederaichbach Nuclear Power Plant (KKN). About $1700 \mathrm{Mg}$ of carbon steel and stainless steel will be melted. The target of this campaign is the unrestricted release of the steel. The handling, conditioning, and the radiological measurement procedures are explained. About 1000 $\mathrm{Mg}$ of so called nonactive material from the controlled area of the $\mathrm{KKN}$ have to be handled. It is necessary to verify the nonexistence of surface contamination. For this purpose a measurement device was developed in which large quantities can be measured in one step.

106

Feizollahi, F., R. Kohout, and A. Suzuki

Decommissioning Waste Management in Canada

CONF-891006; Proceedings of a Joint International Waste Management Conference, 
Kyoto, Japan, October 23-28, 1989, Vol. 1, 658 pp.; (pp. 193-202) (1989)

This paper describes Canadian waste management policy and practices as they pertain to the Gentilly-1 and NPD decommissioning programs. Gentilly-1 was a prototype $250-\mathrm{MW}$ Boiling Light Water (BLW) CANDU nuclear power station owned by Atomic Energy of Canada Limited (AECL). The Station was decommissioned over a $25-\mathrm{MW}$ prototype PHWR CANDU reactor, jointly owned by AECL and Ontario Hydro. The decommissioning of NPD was completed in January 1989. Canada, at the time that the Gentilly-1 decommissioning project was begun, had neither a defined national decommissioning strategy nor a licensed disposal site for nuclear wastes. This not only increased the effort required to define site policy and procedures, it also meant that the project management team had to address the issue of medium-term storage of the wastes until a disposal site becomes available. This paper reviews the challenges faced and the solutions implemented for these two projects. This paper also discusses current developments in Canadian decommissioning and waste management policy and practice, including: recent proposals for decommissioning and waste management and the construction of prototype disposal facilities for low- and medium-level operating and decommissioning wastes.

107

Feizollahi, F., R. Kohout, and A. Suzuki

Decommissioning of Nuclear Fuel Facilities

CONF-891006; Proceedings of a Joint International Waste Management Conference, Kyoto, Japan. October 23-28, 1989, Vol. 1, 658 pp.; (pp. 203-212) (1989)

Nuclear facilities such as power reactors, reprocessing plants, and fucl fabrication plants generally have a limited life of up to 40 years. These facilities when superannuated have to be dismantled and removed carefully, and wastes from such dismantling and removal activities must be disposed of under appropriate control. These operations are comprehensively termed as decommissioning. Power Reactor and Nuclear Fuel Development Corporation (PNC), which has so far dedicated itself to the technical development of fast breeder reactors, reprocessing techniques and MOX fabrication techniques in line with the nuclear development and utilization programs based on national policy of plutonium fuel recycle, is now developing fuel cycle facility decommissioning techniques adaptable to their unique features. These techniques are described in this paper.

108

Feizollahi, F., R. Kohout, and A. Suzuki

\section{Rescarch Program of Decommissioning Material Reuse in JAERI}

CONF-891006; Proceedings of a Joint International Waste Management Conference, Kyoto, Japan, October 23-28, 1989, Vol. 1, 658 pp.; (pp. 213-218) (1989)

Reuse research of the wastes from the reactor decommissioning has been done at the Japan Atomic Encrgy Research Institutc (JAERI) since 1987. This paper describes a fundamental reuse research program of radioactive metal wastes and the future plans about reuse technique development as promising ways of rational waste disposal. As for the former, the melting testing program with radioactive metal coming from the decommissioning of the Japan Power Demonstration Reactor (JPDR) is under way to reveal the material balance and the radioactivity balance during melting of radioactive metals. The latter is in the stage of discussing the materialization of rescarch programs which aim for real reuse of decommissioning matcrials.

109

Feizollahi, F., R. Kohout, and A. Suzuki

Conditioning of Graphite Bricks from Dismantled Gas Cooled Rcactors for Disposal

CONF-891006; Proceedings of a Joint International Waste Management Conference, Kyoto, Japan, October 23-28, 1989, Vol. 1, 658 pp.; (pp. 497-502) (1989)

Dismantling of gas-cooled reactors to decommissioning involves tens of thousands of low-level radioactive graphite bricks containing less than $400 \mathrm{GBq}$ of tritium per metric ton, less than 20) $\mathrm{GBq}$ per metric ton of $\mathrm{C}-14$, and of $\mathrm{Cl}-36$. The long 
half-life of the last two nuclides may require long-term conditioning. Core impregnation is one way to minimize leaching under these conditions. The authors show that core impregnation is possible using extremely durable pitches or bitumens, that inspection is possible by porosity monitoring and $x$-ray examination, and that satisfactory leach test results have been obtained on actual graphite samples from a reactor operated for 20 years. The very simple technology required for industrial implementation is discussed.

\section{0}

Feizollahi, F., R. Kohout, and A. Suzuki

\section{An Information System for the Management of Decommissioning Wastes}

CONF-891006; Procecdings of a Joint International Waste Management Conference, Kyoto, Japan, October 23-28, 1989, Vol. 1, 658 pp.; (pp. 621-628) (1989)

Waste management as part of the decommissioning of nuclear facilities involves considerable expenses. Data processing programs can facilitate a complete documentation and economic treatment of wastes. This documentation is also required by nuclear licensing procedures. In the Federal Republic of Germany, radioactive wastes are not accepted by repositories unless they are accompanied by a documentation informing about the type, condition, radioactivity, and treatment of wastes. Regulations laid down by the German Atomic Energy Law and the Radiation Protection Act for the minimization of personnel and environmental radiation exposure, and for the minimization of waste quantities. This paper discusses the information system ISAB (1) which intends to be a state-of-the-art-and-science vehicle contributing to the optimum fulfillment of the legal requirements specified above. It is a modular program characterized by a data base bookkeeping system and a Decision Supporting System (DSS) which uses artificial intelligence tools. The program's factual status is equivalent to that of the preparatory planning of the decommissioning of nuclear facilities.
111

Feizollahi, F., R. Kohout, and A. Suzuki

The Radioactive Waste Management Program Associated with the Decommissioning of the Former Eurochemic Reprocessing Plant

CONF-891006; Proceedings of a Joint International Waste Management Conference, Kyoto, Japan, October 23-28, 1989, Vol. 1, 658 pp.; (pp. 441-460) (1989)

Since the shutdown of the reprocessing activities at the former EUROCHEMIC reprocessing plant in 1974, large efforts have been undertaken to decontaminate the facilities, to process the reprocessing and decontamination wastes, and to prepare the dismantling of obsolete equipment and installations. This major decommissioning program is outlined in the present paper. The waste management activities include vitrification of FLLW, bituminization of ILLW, processing HLSW and ILSW, plutonium recovery from alpha-bearing solid wastes, and on-site storage of the resulting conditioned wastes. The present status and the experience gained are described in this paper. Cleaning and decontamination of the reprocessing plant and related facilities, such as large storage vessels of ILLW and HLLW, have been successfully carried out. Finally, the paper deals with the dismantling project, launched in 1987, and identifies the major objectives. The current pilot dismantling program is outlined.

\section{2}

Feng, X., E.E. Saad, W.P. Freeborn, P.B. Macedo, I.L. Pegg, R.E. Sassoon, A. Barkatt, and S.M. Finger, Catholic University of America, Vitreous State Laboratory, Washington, DC

Composition Models for the Viscosity and Chemical Durability of West Valley Related Nuclear Waste Glasses

CONF-880201; Waste Management '88: Waste Processing, Transportation, Storage and Disposal - Technical Programs and Public Education, Post, R.G. (ed.), Procecdings of a Conference, Tucson, AZ, Fcbruary 26-March 3, 1988, Vol. 2, 1052 pp.; (pp. 805-810) (1988) 
There are two important criteria that must be satisfied by a nuclear waste glass durability and processability. The chemical composition of the glass must be such that it will not dissolve or erode appreciably faster than the decay of the radioactive materials embedded in it. The second criterion, processability, means that the glass must melt with ease, must be easily pourable, and must not crystallize appreciably. This paper summarizes the development of simple models for predicting the durability and viscosity of nuclear waste glasses from their composition.

\section{3}

Feraday, M.A., International Atomic Energy Agency, Vienna, Austria

\section{International Atomic Energy Agency's Program on Decontamination and Decommissioning}

Nuclear Technology 86(2):99-110 (1989)

The International Atomic Energy Agency (IAEA) is develrping an integrated information base that will systematically cover the technical, regulatory, radiation protection, planning, and economic aspects related to the decontamination and decommissioning (D\&D) of nuclear facilities. The objective of this program is to assist member states in developing the required expertise, equipment, and programs so that they can decommission their nuclear facilities in a safe, timely, and cost-effective manner. In addition to providing information, the IAEA encourages research and provides technical assistance in the form of expert missions, equipment design and procurement, etc., to assist member states in implementing their $D \& D$ programs. The technology contained in some recent IAEA reports is reviewed, including the decontamination, segmentation, and demolition of concrete and stecl; the recycle/reuse of components from decommissioning; and the reduction of occupational exposures in D\&D and the regulatory process in decommissioning. The IAEA's future program is briefly reviewed.

\section{4}

Fleischer, C.C., and H.U. Freund
Explosive Techniques for the Dismantling of Radioactive Concrete Structures

CONF-891077; Decommissioning of Nuclear Installations, Procecdings of the 1989 International Symposium, Brussels, Belgium, October 24-27, 1989. Commission of the European Community, Brusscls, Bclgium; (pp. 264-281) (1989)

The decommissioning of nuclear facilities calls for the controlled removal of activated and/or contaminated matcrials from the insides of biological shielding heavy reinforced or prestressed concrete structures while relying on the outer layers of nonactivated or noncontaminated matcrial to contain the activity. This paper describes development work being carricd out on the controlled use of explosives to cut and remove activated parts of nuclear facilitics without impairing the overall structural integrity. The paper discusses the results obtained and concludes that the controlled usage of explosives offers a safe and favorable dismantling technique for the decommissioning of nuclear facilitics. To investigate the problems associated with the controlled removal of activated material from nuclear facilitics, the Commission of European Communitics (CEC) established, as part of its rescarch program on decommissioning such systems, rescarch projects aimed at studying the various techniques which might be used for the removal of activated material. Phase 1 of this research program was designed to encounter this problem. In order to bring the explosive cutting technique to the degree of control, with respect to safety and radiation protection, that would be needed in decommissioning nuclear facilitics a Phase 2 program of work was prepared

\section{5}

Forde, M.C., and A.J. Batheclor, University of Edinburgh, Edinburgh, Scotland

\section{Evaluation of Structures for Decommissioning Using NDT}

Decommissioning Offshore, Onshore and Nuclear Works, Whytc, I.L. (cd.), Proceedings of the First International Conference, Manchester, United Kingdom, March 22-24, 1988. Thomas 
Telford Limited, London, United Kingdom, 338 pp.; (pp. 201-206) (1988, March 22-24)

It has been shown that problems arise at times when an existing structure is to be decommissioned for cither total reconstruction or permanent demolition. These difficultics can frequently arise due to the fact that working drawings are cither not available or are suspected to be inaccurate. Other problems may occur when, in the absence of working drawings, a structure may have been demolished by fire or other hazard and is reconstructed making partial use of existing components. Examples of two different nondestructive testing (NDT) evaluation techniques for these problems are given. The techniques are the time domain and transicnt dynamic response techniques. This paper concentrates on a masonry bridge and an industrial building totally destroyed by fire except for the foundations.

116

Frost, C.R., Ontario Hydro, Toronto, Ontario, Canada

Proposed Safeguards and Security During Future Decommissioning of Ontario Hydro's Reactors

Nuclear Matcrials Management, Proceedings of the 29th INMM Annual Mecting, Las Vegas, NV, June 26-29, 1988, 959 pp.; (pp. 351-356) (1988, June 29)

A regulatory requirement for the relicensing of Ontaric Hydro's operating CANDU reactors is a documented conceptual decommissioning plan, including safeguards and security. The present conceptual decommissioning plan calls for all irradiated fuel to be transported off-site after greater than or equal to 10 years of the start of reactor decommissioning to a centralized storage and/or disposal center. With no published International Atomic Energy Agency (IAEA) guidelines specifically on decommissioning safeguards and security, the provisions proposed are based on general IAEA requirements, safeguards and security practice during reactor operation, and experience with the decommissioning of Alomic Energy of Canada, Limited reactors. Safeguards are required for irradiated fucl, not for heavy water or tritium. The application of materials accounting, in situ irradiated fucl verification, and containment and surveillance procedures is discussed. Security measures are required during decommissioning to: (a) ensure that all irradiated fucl remains at the storage location or transportation route designated; (b) prevent any deliberate damage to the fuel; (c) keep Ontario Hydro personncl informed of the status of the fucl during storage and transportation; and (d) provide the capability of assistance being called in an emergency.

117

Fujita, R., M. Enda, and T. Morisue, Toshiba Corporation, Nuclear Enginecring Laboratory, Kawasaki, Japan

\section{REDOX Decontamination Technique Development}

CONF-88()201; Waste Management '88: Waste Processing, Transportation, Storage and Disposal - Technical Programs and Public Education, Post, R.G. (ed.), Proceedings of a Conference, Tucson, AZ, February 26-March 3, 1988, Vol. 2, 1052 pp.; (pp. 547-552) (1988)

The decontamination technique is required to apply to irregularly formed metallic wastes, to have a high decontamination rate and decontamination factor, ard to minimize secondary waste volume for component replacement and decommissioning. The authors have developed a new decontamination technique using $\mathrm{Cc}(+4)$, which has a high dissolution ratc i.e., a high decontamination rate and easily regencrates decontamination reagents. The report presents the results of fundamental test, engineering scale test, and the details of equipment design.

118

Fujita, R., M. Enda, and T. Morisue, Toshiba Corporation, Kawasaki, Japan

REDOX Decontamination Technique
Development I - Selection for Dissolutive and
Regencrative Conditions

Journal of Nuclear Science and Technology 26(.3):339-340) (1989, March) 
A decontamination technique with a high decontamination rate and decontamination factor is needed for irregularly formed metallic waste to minimize secondary waste volume for nuclcar facility component replacement and decommissioning. The authors developed a new decontamination technique using $\mathrm{Ce}-(+) 4$ for decommissioning, called the REDOX decontamination technique. This paper investigates decontamination conditions and regeneration conditions in a nonradioactive fundamental test. The decontamination conditions, e.g. dissolution conditions for stainless stecl and carbon steel, were selected using simulated samples in nitric acid solutions in varying $\mathrm{Ce}-(+) 4$ concentrations, HNO-3 concentrations, temperatures, and linear flow rates of decontamination solutions. The regeneration conditions for the decontamination reagent were selected in various electrode materials and varying electrode separation distances, anode area/cathode area ratios, current densities, $\mathrm{Ce}-(+) 3$ concentrations, and HNO-4 concentrations. The REDOX decontamination technique was ascertained to have a high dissolution rate, and the decontamination reagent was ascertained to be regenerated effectively by electrolysis.

119

Fujita, R., M. Enda, and T. Morisue, Toshiba Corporation, Kawasaki, Japan

REDOX Decontamination Technique Development II - REDOX Decontamination System Using Pilot Plant

Journal of Nuclear Science and Technology 26(4):449-458 (1989, April)

The authors have developed a new decontamination technique using $\mathrm{Ce}(+4)$ for decommissioning; it is called the REDOX decontamination technique. In Part I of this report, the REDOX decontamination conditions and stainless stecl and carbon steel dissolution conditions were established in fundamental tests. In Part II, the authors describe the establishment of the REDOX decontamination system in engineering-scale equipment based on the fundamental test results. In comparison with the fundamental test results, the $\mathrm{Ce}(+4)$ generation rate and current efficiency, the stainless steel and carbon steel dissolution rate, and the $\mathrm{Ce}(+4)$ regencration rate and current efficiency were not affected by scaling up.

\section{0}

Fukuzawa, R., N. Kondo, Y. Kamiyama, T. Kawasato, and T. Hiraga, Toda Construction Company Limited, Toda, Japan

Rescarch and Development of a Machine for the Removing System of Biological Shicld Wall of a Nuclear Reactor

Robot 67:39-45 (1989, March)

This paper describes a system for the removal of the heavily reinforced biological shicld wall of a nuclear facility using diamond saws (disc saws). The shicld is removed during decommissioning. A cutting experiment has been carried out on a full-scale model. The cutting speed was controlled automatically and remotely. The experiment proves that the heavily reinforced concrete section with D51-mm diameter deformed bars can be cut in the depth of $1(0) \mathrm{mm}$ speedily, safely, and continuously with precision.

121

Fultz, K.O., U.S. General Accounting Office, Resources, Community, and Economic Development Division, Washington, DC

Nuclear Regulation: NRC's Decommissioning Procedures and Critcria Need to Be Strengthened - Report to the Chairman, Environment, Encrgy, and Natural Resources Subcommittec, Committec on Government Operations, House of Representatives

GAO/RCED-89-119; 51 pp. (1989, May 26),

The Nuclear Regulatory Commission (NRC) needs to ensure that licensecs appropriately decontaminate their facilities. Under current regulations, NRC cannot specifically require additional cleanup once it terminates a license. On the basis of a review of eight fuel cycle licensecs, GAO found that NRC fully or partially released two sites for unrestricted use where contamination at one was up to four times, and at the other, up to 320) times higher than NRC's 
guidelines allowed. The other six cases aiso indicated instances of poor regulatory oversight, either because NRC did not require licensecs to fully document the decontamination activities conducted or the data that NRC did have were incomplete. Problems were observed with buried radioactive waste at four out of five facilities, with licensec records of the types and amounts of waste buried being incomplete or nonexistent. All five sites have groundwater contamination higher than federal drinking water standards. Further, no federal standards exist for acceptable levels of radiation that can remain after NRC terminates a license. As a result, licensees are using NRC guidance developed in the early 1970's to decommission their facilities.

\section{2}

Gee, E.F., GPU Nuclear Corporation, Middletown, PA

\section{Respiratory Protection - Lessons Learned at TMI}

Transactions of the American Nuclear Society 57:480-481; Nuclear Fission, Procecdings of the 1988 International Conference, Washington, DC, October 30-November 4, 1988 (1988)

At the time of the Three Mile Island Unit 2 (TMI-2) accident, the author was ill prepared for respiratory protection demands. Airborne radioactivity concentrations following the accident reached 1000$)$ times the maximum permissible concentration. Surface contamination levels ranged upward of 1 $\mathrm{rad} / \mathrm{smear}$. Oxygen concentrations in the reactor building were less than $14 \%$ prior to the first purge. Additionally, the author projected a mass usage of a varicty of respirators in excess of $200 /$ day during a cleanup and recovery process estimated to last for several years. To this end, the author faced a multitude of short- and long-term challenges necessary to expand the scope of the program. Some of those most significant challenges are discussed.

\section{3}

Genova, M., F. Mantega, and T. Vitiello, Centro Informazioni Studi Espericnze, Milan, Italy; Ente Nazionale per l'Energia Elettrica, Rome, Italy
Decommissioning of Garigliano Nuclear Power Station

Energia Nucleare 6(3):34-37 (1989, September-December)

The decommissioning of the Garigliano Nuclear Power Station involves the safe storage of the reactor building for some decades before final dismantling. The plan for safe storage has the following main objectives: (1) radioactivity containment for a long time with much reduced survelllance and minimization of active components (to avold maintenance); (2) safe storage operations realized with extremely low occupational exposure; and (3) reduced effect of the above interventions on final dismantling. As for long-term contamination containment, use is made of three sequence barriers already available and conveniently adapted to contamination sealing. To assure integrity of the barricrs, the plan includes realization of a system to keep the inner humidity of the reactor building at very low values. This system is also capable of passive operation. To facilitate the final dismantling, the plan includes reversibility of some operations of safe storage of the systems that should be activated again at the end of the storage time. Morcover, a data bank will be provided as a support to final dismantling.

\section{4}

Goertz, R., and R. Neider, Brenk Systemplanung, Aachen, Federal Republic of Germany; Bundesanstalt fuer Materialforschung und Prufung, Berlin, Federal Republic of Germany

Policy and Criteria for the Recycle and Reuse of Very Low Level Contaminated Materials from Maintenance, Refurbishment and Decommissioning of Nuclear Facilities in the Federal Republic of Germany

CONF-880404; Procecdings of an International Radiation Prolection Association Congress, Sydncy, Australia, April 10, 1988; (pp. 1231-1234) (1988) 
In the course of maintenance, refurbishment and decommissioning of nuclear facilities large amounts of materials with very low level specific or surface activities arise, which may be handled either as conventional waste, reused and recycled conventionally or treated as radioactive waste. In any case it is necessary to define criteria which allow to discriminate between the two main options. When establishing such critcria one should start at the basic radiation protection criteria p'ven by ICRP 26.

\section{5}

Gregory, A.R., Central Electricity Generating Board, London, United Kingdom

\section{Decommissioning of Nuclear Power Stations}

Decommissioning of Nuclear Facilitics, Proceedings of an International Scminar, London, United Kingdom, July 6-7, 1988; (7 pp.) (1988, July 7)

Over the last decade or so decomrnissioning has become the widely accepted word 10 describe the whole process of dealing with a wide varicty of nuclear facilities which have come to the end of their lives. Decommissioning covers the whole process following cessation of electricity generation. It includes defuclling, dismantlement of plant and building, packaging of radioactive materials, site clearances, and all aspects of safety. It does not include plant rundown, towards the end of its life, waste management policy, or disposal. The Central Electricity Gencrating Board decommissioning programs are discussed.

126

Grennhalgh, G.

1990 Likely to be Critical Year for Sweden's Phase-Out Policy

Atomnaya Tekhnika za Rubczhom 12:23-25 (1988, December)

The problems arising in Sweden after the decision $t 0$ shut-down 12 operating NPP power units by 2010) are considered. Referendum carried out in 198() resulted in this solution. The final decision as to what power units are to be shut-down and in what priority will be made after 199). Denying NPP as a source of clectricity production which at present constitutes approximately half of the electricity produced in Sweden, one has to resort to the solution of the problem of energy supply using other sources. Besides, shut-down of the first NPP power units will lead to increase of electricity cost by approximatcly a factor of two.

127

Guassardo, G., and E.W. Hagen, Ansaldo S.p.A., Genoa, Italy

Operator Action Model in the Probabilistic Safety Study of Latina MAGNOX Nuclear Power Plant

CONF-880633; Human Factors and Power Plants, Procecdings of an International Conference, Montercy, CA, June 5-8, 1988; (pp. 29()-296) (1988)

The aim of this paper is to illustrate the methodolopy adopted to model the operator actions in the Probabilistic Safety Study (PSS) of the Magnox nuclear power plant (NPP) situated at Latina (ltaly). This reactor design has some pecullar aspects distinctive with respect to L.WRs and PWRs, in particular the intrinsic slowness of the thermal transients. Furthermore, the Latina NPP shows a low degree of safety feature automation, since the plant was designed in the fifties and was put into operation in the early sixtles. Therefore, the modelling of operator actions had to account for such plant characteristics.

\section{8}

Haferkamp, H., F.W. Bach, T. Vinke, A. Kinzel, N. Mack, M. Kuboschek, and K. Grobe

Study Into the Applicabilities of Lasers for the Dismantling of Decommissioned Nuclear Power Plant

Kurzberichle aus der Bauforschung 30(29):113-116 (1989, February) 
The profect was intended to sereen current laser technology for potential applications of laser beams in the dismantling of decommissioned nuclear power plant. As with CO-2, Nd-YAG, or excimer lasers, developments clearly proceed towards higher output power. The market survey shows the CO-2 laser to be the most efficient at present, with a great number of laser units available on the market in the range up to $5 \mathrm{~kW}$, and some in the range up $1015 \mathrm{~kW}$. The CO-2 laser has exclusively been used so far for cutting work in stecl plates thicker than $10 \mathrm{~mm}$. Characteristic conditions of application include the high output power of more than $2 \mathrm{~kW}$, long beam lengths, oxygen supply at strongly increased working pressure, sometimes from external sources. The maximum cutling work achieved in the laboratory was $110 \mathrm{~mm}$ in structural stecl, $90 \mathrm{~mm}$ in austenitic stecl, and $160 \mathrm{~mm}$ in concrete, all under conditions of easy aceess to the material. It remains to he examined whether stecl cutting work at constrained positions will allow separation of wall thicknesses of more than $10 \mathrm{~mm}$. Laser beam cutting under water is feasible in principle but has not been much studicd yet. There also are only few sampling results of measurements of dust and acrosol quantities resulting from laser beam cutting work.

129

Hafcrkamp, H., H. Louis, and G. Mcicr

\section{Submerged Cutting of Stecl by Abrasive Water Jets}

CONF-891077; Decommissioning of Nuclear Installations, Procecdings of the 1989 International Symposium, Brussels, Belgium, October 24-27, 1989. Commission of the European Community, Brussels, Bclgium; ( $p$. 242-253) (1989)

A special cutting head for underwater use was designed and built. "Yests were carried out to find uscful parameters for submerged cutting. With regard to the production of secondary waste with abrasive flow rate had tc be minimized. It secms $t()$ be useful to realize this demand by using a small water jet nozzle (up to $.4 \mathrm{~mm}$ diameter) and a high pressure (up to $40(0)$ bar) with an optimal abrasive flow rate of about $5 \mathrm{~s} / \mathrm{s}$. In case of a higher ambient pressure a decrease of the cutting performance was measured. But this decreasc was not important regarding decommissioning because the ambient pressure is less than 2 bar. An air mantle noziale was adapted to the cutting head to improve tho working distance under water. The air mantle surrounding the abrasive jet lowers the friction between jet and surrounding water and increases the cutting efficiency in case of greater working distances.

\section{0}

Haghighat, A., Pennsylvania State University, University Park, PA

Investigation of the Control Rod Material Presence in the TMI-2 Lower Head

Transactions of the Amcrican Nuclear Society 59:348-50) (1989, Junc 8)

This is a follow-up study on the determination of the material distribution in the Three Mile Island Unit 2 (TM1-2) lower head from gamma spectra. In the present study, the author investigates the possibility that the control rod materials (80) wt \% silver, $15 \mathrm{wt}$ $\%$ indium, and $5 \mathrm{wt} \%$ cadmium) exist in the nonfuel layer, as has been suggested by other researchers.

131

Hashish, M., Flow Industries, Inc., Kent, WA

\section{Culting with Abrasive Waterjets}

Mechanical Enginecring 3:60-69 (1984, March)

The ability of an abrasive waterjet to cut advanced matcrials is unmatched by current mechanical or thermal cutting methods. Abrasive waterjets can be used on titanium, ceramics, metallic honeycomb structures, glass, Kevlar, graphite, and bonding compounds without any delamination or inducement of thermal or deformation stresses along the cutting path. Cutting applications also include paper, cloth, wood, plastic, fibcrglass and rocks of medium hardness. This article outlines the principles, systems components, performance, cconomics, environmental considerations, and industrial applications of abrasive waterjet cutting.

132

Hashish, M., Flow Industrics, Inc., Kent, WA 


\section{Cutting with Abrasive Watcrjets}

The Carbide and Tool Journal 5:16-23 (1984, September-October)

The ability of an abrasive waterjet to cut advanced materials is unmatched by current mechanical or thermal cutting methods. Ahrasive waterjets can be used on titanium, ceramics, metallic honeycomb structures, glass, Kevlar, graphite, and bonding compounds without any delamination or inducement of thermal or deformation stresses along the cutting path. Cutting applications also include paper, cloth, wood, plastic, fiberglass and rocks of medium hardness. This article outlines the principles, systems components, performance, economics, environmental considerations, and ind ustrial applications of abrasive waterjet cutting.

\section{3}

Hayle, J.C.

\section{Mecting of the Advisory Pancl for the Three Mile Island, Unit 2}

Federal Register 54(172):37174 (19839, September 7)

Notice was given pursuant to the Federal Advisory Committee Act that the Advisory Pancl for the Decontamination of Three Mile Island, Unit 2 (TMI-2) will be mecting on September 21, 1989. This meeting will be open to the public. At the meeting, the pancl will receive a status report on the progress of defueling from the licensec, GPU Nuclear Corporation. The licensec will also discuss the radiation monitoring program around TMI-2, and the schedule and proposed funding for the remainder of the cleanup. The Nuclear Regulatory Commission staff will summarize the findings of Final Supplement 3 to the Programmatic Environmental Impact Statement related to decontamination and disposal of radioactive wastes resulting from the March 28, 1979 accident at TMI-2.

\section{4}

Hayward, D.

\section{The End of the Nuclear Follics}

New Civil Enginecr 874:22-24 (1989, December 7)

Demolition of the first major section of any decommissioned United Kingdom nuclear power station is about to enter its most crucial stage. In December 1989, a Pound 250,(0)() remote control dismantling machine will be delivered to Scllaficld nuclear fucl reprocessing plant to begin the slow task of removing highly radioactive glass fiber lining from one of the old Windscale reactor's twin chimncys. Some work has already been done but dismantling the top $27 \mathrm{~m}$ of the $125-\mathrm{m}$ chimneys will take 10 years and be enormously expensive. No cranes are allowed in case of damage to the Sellaficld Reprocessing Plant which surrounds the Windscale reactors and all demolition materials have to be cut up into sections small enough to travel in the hoists crected on both chimneys. On the chimncy of the No. 1 reactor, where the 1957 Windscale fire occurred, radiation levels are high, and remote handling equipment must be used. The equipment delivered in December 1989 will be used to remove the glass fiber insulating lining to the filter box at the top of the chimney stack, where it is hoped most of the contamination is concentrated.

\section{5}

Hess, W., E. Schenker, G. Petzhold, and H. Dicwald

\section{Very Soft Works at Room Temperature}

Nuclear Enginecring International 34(420):35-36 (1989, July)

The new Very Soft (vs) decontamination process developed by the Paul Scherrer Institut (Werenlingen, Switzerland) incorporates a number of special features: (1) Very low solvent concentrations minimize possible corrosion attacks as well as waste volume. (2) Temperatures are well below the 9 ) degrec $C$ normally required; indeed, the process can operate at room temperature. The process can, however, be speeded up by raising the temperature and/or using ultrasonic transmilters. (3) Acceptable results can be achicved with just one decontamination cycle lasting less than 12 hours. (4) The process can be used for dismounted components as a diving technique, for complete loops as a 
flooding technique, and for nondismountable components as a spraying/flushing technique. The process, which is being used for decontamination of reactor loop components, is based on a chemical pretreatmont at room temperature using diluted solutions of permanganate and chromic acid. The chemical post-treatment works best using diluted solutions of organic acids with the addition of roducing agents, unless the organic acid employed may be used as a reducing agent at the same time.

\section{6}

Higuchi, S., T. Onuma, and H. Akimoto, Hitachi Plant Enginecring and Construction Company Limited, Tokyo, Japan

\section{Chemical Decontamination Method for Stainless Stcel}

Japanese Patent JP 1-3113())/A/; 5 pp. (1989, December 15)

The present invention concerns a chemical decontaminating method for radioactive wastes made of stainless stecls. Decontaminants are immersed in a sulfuric acid solution in the first step and then immersed in an aqueous solution in which oxidative metal salts are added to sulfuric acid in the sceond step. In these fundamental steps, a portion of metal parts of the decontaminants and a metal member caused ro act as a sacrifice anode are short-circuited to carry out decontamination in the first step. Those motals showing spontancous potential more basic than the natural potential of the decontaminants are used in the sulfuric acidic solution as the short-circuiting metal. Further, the decontaminating vessel is partitioned by means of lon exchange resins or insulation partition plates, in which decontaminants are placed on one portion and the sacrifice anode was placed on the other portion. The decontaminates and the sacrifice anode are short-circuited at the outside of the vessel by a conduction line. According to this mothod, there is an effect of reducing the amount of oxidative metal required for decontaminating passivated radioactive metal wastes of stainless stecls.

137

Hildebrand, J.E., GPU Nuclear Corporation, Parsippany, NJ

\section{Personnd Contamination Protection Techniques Applied During the TMI-2 Cleanup}

Transactions of the American Nuclear Society 57:481-482; Nuclear Fission, Procecdings of the 1988 International Conference, Washington, DC, October 30-November 4, 1988 (1988)

The severe damage to the Three Mile Island Unit 2 (TMI-2) core and the subsequent discharge of reactor coolant to the reactor and auxillary bulldings resulted in extremely hostile radiological environments in the TMI-2 plant. High fission product surface contamination and radiation levels necessitated the implementation of innovative techniques and methods in performing cleanup operations while assuring effective as low as reasonably achievable (ALARA) practices. The approach used by GPU Nuclear throughout the cleanup in applying protective clothing requirements was to consider the overall health risk to the worker, including factors such as cardiopulmonary stress, visual and hearing acuil, and heat stress. In applying protective clothing requirements, trade-off considerations had to be made between preventing skin contaminations and possibly overprotecting the worker, thus impacting his ability to perform his intended task at maximum efficiency and in accordance with ALARA principles.

\section{8}

Hoffman, W.D., West Valley Nuclear Services Company, Inc., West Valley, NY

Public Attitudes Near a Nuclcar Waste Sitc: Survey Trends from the West Valley Demonstration Project

CONF-88(201; Waste Management '88: Waste Processing, Transportation, Storage and Disposal - Technical Programs and Public Education, Post, R.G. (ed.), Proceedings of a Conference, Tucson, AZ, Fcbruary 26-March 3, 1988, Vol. 2, 1052 pp.; (pp. 583-589) (1988)

This paper discusses results from the 1987 survey taken at an open house event at the West Valley Demonstration Project where a large nuclear waste cleanup is in progress. Over 120) people were polled on the priorities they give to radioactive waste 
cleanup, their attitudes toward nuclear encrgy, and their opinions on the issues of high and low level waste siting. Responses will be compared with carlicr West Vallcy data to establish trends in public attitudes on nuclear issues. A demographic analysis will describe the population surveyed. The bottom line of the study is to gauge public perception of radloactive waste cleanup, nuclear encrgy, and waste siting. A comprehensive effort is made to statistically correlate demographic variables with nuclear attitudes.

\section{9}

Hoffmann, R., and B. Leidenberger

Optimization of Measurement Techniques for Very Low Level Radioactive Waste Material

CONF-891077; Decommissioning of Nuclear Installations, Procecdings of the 1989 International Symposium, Brusscls, Belgium, October 24-27, 1989. Commission of the European Community, Brussels, Bclgium; 11 pp. (1989)

In order to optimize measurements of waste material, relative radiotoxicities of waste nuclides were defined. It was found after that the hard to detect nuclides like $\mathrm{Fe}-55, \mathrm{Ni}-59$, Ni-63 are of minor radiological relevance and that standard beta or gamma measurements suffice if alpha contamination can be excluded. For the determination of suitability for relcase measurements, 20 different detectors were used in test measurements covering 5 typical geometries of contaminated waste material, the contamination consisting of Carbon-14, Pm-147, Cobalt-60), Cesium-137, Sr-9()/Y-9(), Cr-51, and Am-241. It was found that in most geometries proportional counters are adequate for relcase measurements while for the detection of alpha radiation small detectors like surface barricr detectors, photodiodes or GM counters are needed in difficult geometries. In decommissioning nuclear installations, various types of waste materials which are either free of activity or activated/contaminated have to be released. It was the aim of this project to derive a measurement strategy which takes into account the waste composition as well as the radiological impact of the waste nuclides, and which optimizes the eligible measurement techniques with respect to accuracy, time, and cost.

140)

Holahan, G.M.

Michigan State University TRIGA Nuclear Reactor: Order Authorizing Dismantlement of Facility and Disposition of Component Parts

Federal Register 54(135):29957-29958 (1989, July 17)

By application dated January 20, 1989, as supplemented on May 4, 1989, the Michigan State University (licensec) requested authorization to dismantle the TRICA Nuclear Reactor, Facility Licensc No. R-114, located in East Lansing, Michigan and to dispose of the component parts, in accordance with the plan submitted as part of the application. A "Proposed Issuance of Orders Authorizing Disposition of Component Parts and Terminating Facility License" was published in the Federal Register on March 2, 1989. No request for a hearing or petition for leave to intervene was filed following notice of the proposed action.

141

Holahan, G.M.

The University of California, Berkeley: Order Authorizing Dismantling of Facility and Disposition of Component Parts

Federal Register 54(180):33579 (1989, September 19)

The University of California, Berkeley requested authorization to dismantle the TRIGA rescarch reactor facility and to dispose of the component parts. The Nuclear Regulatory Commission has revicwed the application in accordance with the provisions of the Commission's rules and regulations and has found that the dismantling and disposal of component parts in accordance with the licensec's dismantling plan will be in accordance with the regulations in 10) CFR chapter 1 , and will not be inimical to the common defense and security or to the health and safety of the public. 
142

Horiguchi, J., T. Tsubahara, and Y. Yamada, Tokyo Electric Power Company, Tokyo, Japan

\section{Development of Rock Bed Boring Machine Using Ultra-High Pressure Water}

Jet Cutting Technology, Proceedings of the Eighth International Symposium, Duram, England, Scptember 9-11, 1986; (pp. 241-248) (1986)

The purpose of this study was to carry out research on and ultimatcly develop a rockbed boring machine using ultra-high pressure water. This report describes the results of rockbed boring tests. The apparatus used for this test includes a ultra-high pressure water jet generator unit, which is, in fact, an updated and improved conventional rotary boring machine. The bit to bore hole is $46 \mathrm{~mm}$ in diameter in which four units of wifices $0.28 \mathrm{~mm}$ in inner diameter are installed as the jet water ejectors. The rod is of dual pipe construction, the inner pipe is for ultra-high presiure water running and the space between the inner pipe and the outer pipe is for make-up water running tos discharge slime. The experiment was carried out by boring six different types of specimens. Three types of bits, all different in shape, were tested for boring, with ultra-high pressure water varying from $2300,2800,3300$, to $3800 \mathrm{~kg} \mathrm{f} / \mathrm{sq} \mathrm{cm}$. The experimental results showed that the boring speed became 3-4 times greater than that of a conventional boring machine for soft rocks, and 2-3 times greater for hard rocks. The tendency for the boring speed to increase as jet water pressure rose was observed. So was a relationship between the boring speed and longitudinal wave velocity. However, it was not always the case that the boring speed was proportional to uniaxial compression strength in the case of hard rocks.

\section{3}

House of Commons Energy Committee, London, England, United Kingdom

Standpipe Distortion at Hinkley Point 'A' Power Station and the Cost of Decommissioning Magnox Reactors
HC-88; House of Commons Second Report from the Energy Committee (Session 1986-87); 110 pp. (1987, March 11)

This report arises from two articles which appeared in The London Times of 6 November 1986. The first highlighted a corrosion problem with a number of standpipes on Reactor 1 at Hinkley Point 'A', and implied that this might iead to early shutdown of the station. The second article asserted that the cost of decommissioning Magnox reactors (of the type found at Hinkley Point 'A') could be 2.7 billion pounds stcrling per station. Such a figure might raise serious doubts about the economic viability of the entire United Kingdom nuclear program. The House of Commons Energy Committee agreed to take evidence on the factual accuracy of these reports. The committee also thought it opportune to examine the broader issues of press coverage of the civil nuclear power program, the attitude of the Central Electricity Generating Board (CEGB) to public accountability, and the effectiveness of the NII. This brief inquiry highlights these important issues. The report reconimended: (1) that the government give its urgent attention to ensuring that NII can recruit and retain sufficient staff of sufficient quality to discharge all its responsibilities; and (2) that the government carefully considers whether it would be more appropriate to direct the CEGB, both in its annual accounts and in its forthcoming update of Analysis of Generating Costs, to use as its planning assumption the dismantling of nuclear reactors as soon as technically feasible.

\section{4}

House of Commons Energy Committee, London, England, United Kingdom

Government Observations on the Second Report from the Committee (Session 1986-87) on Standpipe Distortion at Hinkley Point 'A' Power Station and the Cost of Decommissioning Magnox Reactors and on the Third Report (Session 1986-87) on the Effect of Oil and Gas Prices on Activity in the North Sea

House of Commons First Special Report from the Energy Committee (Session 1987-88) - 205; 12 pp. (1987, December 9) 
This special report contains the government's response to the recommendations of the Committee's Second Report, dated 11 March, 1987. The Second Report recommended: (1) that the Government give its urgent attention to ensuring that NII can recruit and retain sufficient staff of sufficient quality to discharge all its responsibilities; and (2) that the government carefully consider whether it would be more appropriate to direct the Central Electricity Generating Board (CEGB), both in its annual accounts and in its forthcoming update of Analysis of Generating Costs, to use as its planning assumption the dismantling of nuclear reactors as soon as technically feasible. Referring to the decommissioning of the Windscale AGR and the Shippingport PWR, the government noted several reasons for its current policy of timing of the three stages of decommissioning, with Stage 3 almost certain to be delayed for several decades, after levels of radioactivity in shielding and pressure vessels had decayed. CEGB advise that Stage 3 decommissioning about 100 years after shutdown is the most effective way of ensuring that the principle of ALARA is achieved in practice. The government agrees with CEGB that there is no general technical justification for early Stage 3 decommissioning. CEGB indicated to the committee in January 1987 that a change in accounting principles on the lines recommended by the committee might have a relatively small effect upon current electricity prices if applicd to new power stations. With regard to existing power stations, if full provision were now made for the earliest possible decommissioning, there would be a substantial addition to CEGB's costs upon current electricity prices, of the order of 200 million pounds sterling in each of the next ten years.

\section{5}

Howard, C.G., C.B. Jolliffe, and D.J. Lee, United Kingdom Atomic Energy Authority, Atomic Energy Establishment, Chemistry Division, Winfrith, United Kingdom

Immobilization in Cement of Ion Exchange Resins Arising from the Purification of Reagents Used for the Decontamination of Reactor Circuits - Fifth Semestrial Report July-December 1988
AEEW-M-2558; CPDG-88-P208; 28 pp. (1989, February)

Previous work has shown that strong cation and anion resiris can be successfully immobilized in cement in blended cement systems. The formulation which appears acceptable is produced from a 9 to 1 blend of ground granulated blast furnace slag (BFS) and ordinary Portland cement (OPC) containing $28 \%$ ion exchange resin in the water saturated form. If $6 \%$ microsilica is added to the blended cement the waste loading can be increased to $36 \%$. Large- and small-scale evaluation of the physical properties of the product show no detrimental effects over 180) days of storage. This report contains further data on the properties of cemented ion exchange resin including leacn resistance and porosity. Also included is a proposed flowsheet for the cementation of ion exchange resins produced by the reactor at Winfrith.

\section{6}

Huber, B., Commission of the European Communities, Brussels, Belgium

\section{EC Starts New Rescarch Programme}

Nuclear Enginecring International 34(420):34 (1989, July)

The European Community (EC) has concluded a five-year research and development program on decommissioning and is now starting up a new program. The research has been carried out by public organizations or private companies in the member states under shared-cost contracts. Typically, the EC assumes $40-50 \%$ of the cost. The research is focused on the safety and protection aspects of decommissioning. The 1984-1988 program comprised 75 research contracts. The findings were discussed at a conference in Brussels October 24-27, 1989. The new program places more emphasis on the testing of decommissioning techniques currently in practice. Most of these tests will be carried out within the framework of pilot dismantling projects.

\section{7}

International Atomic Energy Agency, Vienna, Austria 
Decontamination and Decommissioning of Nuclear Facilities - Final Report of Three Research Coordination Meetings Held Between 1984 and 1987

IAEA-TECDOC-511; 102 pp. (1989, June)

Since 1973, when the Internatiunal Atomic Energy Agency (IAEA) first introduced the subject of decontamination and decommissioning into its program, 12 agency reports reflecting the needs of the member states on these topics have been published. These reports summarize the work done by various technical committees, advisory groups, and international symposia. While the basic technology to accomplish decontamination and decommissioning (D\&D) is fairly well developed, IAEA feels that a more rapid exchange of information and coordination of work are required to foster technology, reduce duplication of effort, and provide useful results for member states planning $D \& D$ activities. Although IAEA's limited financial resources do not make possible direct support of every research work in this field, the IAEA Coordinated Research Programme (CRP) creates a forum for outstanding workers from different member states brought into closer contact with one another to provide for more effective interaction and, perhaps subsequently, closer collaboration. The first CRP on decontamination and decommissioning was initiated in 1984. Nineteen experts from 11 member states and two international organizations (CEC, OECD/NEA) took part in the three research coordination meetings (RCM) during 1984-1987. The final RCM took place in Pittsburgh, in conjunction with the 1987 International Decommissioning Symposium (sponsored by the U.S. Department of Energy and organized in cooperation with the IAEA and OECD/NEA). The present document summarizes the salient features and achievements of the coordinated research work performed during the 1984-1987 program period. The document consists of two parts: Part 1, Summary of the three research coordination meetings; and Part 2, Final submissions by participants on the research work performed during 1984-1987. A separate abstract was prepared for each of the seven reports presented.
148

International Seminar on the Decommissioning of Nuclear Facilitics

Decommissioning of Nuclear Facilities, Proceedings of an International Seminar, London, United Kingdom, July 6-7, 1988 (1988, July 7)

The decommissioning of nuclear facilities is discussed with relevance to Shippingport pressurized water reactor (PWR), Windscale Advanced Gas-Cooled Reactor, Chernobyl Unit 4, the Magnox reactors, and other installations.

\section{9}

Ishikawa, M., and S. Yanagihara, Japan Atomic Energy Research Institute, Tokai Research Establishment, Department of Japan Power Demonstration Reactor, Tokai, Ibaraki, Japan

\section{Dismantling of JPDR Internals Gets Under Way Using Plasma Arc Cutting}

Nuclear Engineering International 33(408):27-28 (1988)

The Japan Power Demonstration Reactor (JPDR) decommissioning program was initiated in 1981 by the Japan Atomic Energy Research Institute (JAERI) under contract with the Science and Technology Agency in Japan. Technologies necessary for reactor dismantling were developed in the first stage of the program. Underwater plasma arc cutting was selected for dismantling the JPDR reactor internals because it provided the required superion cutting performance and precision control features needed for remote cutting in a high radiation environment. A robotic manipulator sysiem was used with the cutting technique.

150

Jenne, C., Coopers and Lybrand, London, United Kingdom

\section{Economic Aspects of Decommissioning}

Decommissioning of Nuclear Facilities, Proceedings of an International Seminar, 
London, United Kingdom, July 6-7, 1988; (16 pp.) (1988, July 7)

The author suggests that decommissioning does raise some important issues for regulation and financing of a privatized industry but, despite this, the economics of nuclear do remain insensitive. The significance of decommissioning costs are examined in a number of contexts, including nuclear unit generating costs and financing requirements. The author addresses the degree of uncertainty in the decommissioning cost estimates. With privatization on the horizon, the author considers the significance of decommissioning and the associated uncertainty for the investor; the author considers regulatory issues raised in relation to funding, accounting policy, and electricity pricing.

\section{1}

Joseph, I., A. Mathur, C. Capozzi, J. Sehgal, D. Butts, D. McPherson, and L.D. Pye, Alfred University, New York State College of Ceramics, Alfred, NY

\section{Crystallization Behavior of a Fully Simulated West Valley Borosilicate Glass}

CONF-880201; Waste Management '88: Waste Processing, Transportation, Storage and Disposal - Technical Programs and Public Education, Post, R.G. (ed.), Proceedings of a Conference, Tucson, AZ, February 26-March 3, 1988, Vol. 2, 1052 pp.; (pp. 487-491) (1988)

The crystallization behavior of a fully-simulated West Valley reference borosilicate glass was studied. The studies were concluded on fully oxidized and partially reduced samples of the glass. Glass samples were heat treated isothermally over the temperature range of 500-1000 degrees $\mathrm{C}$ for time periods ranging from 1 to 384 hours. The main crystalline phases observed in the heat treated samples were spinel, acmite, cerium-thorium oxide. The volume percent of crystals in heat-treated samples were determined by image analysis in conjunction with optical microscopy. Based on these results, quantitative time/temperature/transformation diagrams were constructed.
152

Kamat, G.R., Bhabha Atomic Research Centre, Bombay, India

Pitting and its Control During Electropolishing of Stainless Stecl

Transactions of the Indian Institute of Metallurgy 40(4):343-345 (1987, August)

Attempts made by the author to reduce surface pitting on austenitic stainless steel by carrying out electropolishing in the presence of a strong oxidizing agent like potassium dichromate are discussed.

\section{3}

Katayama, Y.B., and L.K. Holton, Jr., Pacific Northwest Laboratory, Richland, WA

324 and 325 Building Hot Cell Cleanout Program - Decontamination of C-Cell

PNL-6976; 36 pp. (1989, October)

During FY 1989 the decontamination of C-Cell of Hanford's 324 Building was completed as part of the 324 and 325 Building Hot Cell Cleanout Program under the SFMP. The decontamination effort was completed using a series of remote and contact decontamination techniques. Initial radiation readings in the $\mathrm{C}$-Cell averaged $50 \mathrm{rad} / \mathrm{hr}$ and were reduced remotely to less than $200 \mathrm{mrad} / \mathrm{hr}$ using an alkaline foam cleaner followed by 5000 -psi water flush. Contact decontamination was then permissible using ultra high- pressure water $(36,000 \mathrm{psi})$, reducing the average radiation level in the cell to less than $86 \mathrm{mrem} / \mathrm{hr}$. The approach used in decontaminating $\mathrm{C}$-Cell resulted in a savings in radiation exposure of $87 \%$ and a cost savings of $39 \%$, compared to a hands-on procedure used in A-Cell, 324 Building in 1987. The radiation dose and the costs to achieve a 244 -fold reduction in radiation contamination were $1.65 \mathrm{mrem} / \mathrm{sq} \mathrm{ft}$ and $\$ 96 / \mathrm{sq} \mathrm{ft}$ of cell surface area.

\section{4}

Kawasaki, M., E. Tachikawa, H. Yasunaka, T. Suwa, and T. Gorai, International Atomic Energy Agency, Vienna, Austria 
Rescarch and Development of LWR System Decontamination - Mechanochemical and Redox Decontamination Methods

IAEA-TECDOC-511; (pp. 65-78) (1989, June)

In order to satisfy requirements for efficient crud removal from contaminated surfaces and easy subsequent treatment of spent decontamination solutions, two methods were developed, tested, and applied in the decommissioning of the Japan Power Demonstration Reactor (JPDR) plant. The specimens of pipes and tubes of the primary system were thoroughly examined with use of chemical analysis, $x$-ray, activity measurement, and electron microscopy. High content of chromium in the crud was ascribed to poor quality control of cooling water in the early stage of plant operation. Since decontamination with common chemical reagents was not effective, further tests were modified in two ways. The first method consisted of a mechanico-chemical procedure, in the second various redox decontamination reagents were used. Subsequently, laboratory testing was replaced by large-scale tests performed in decontamination loops, designed and constructed for this purpose. In decontamination of samples from nuclear power plants by various decontamination reagents, it was observed that the redox method gave a satisfactory decontamination factor, regardless of the chromium-content, and could be successfully used as a decontamination method for pre- and/or post-dismantling of a reactor.

155

Kennedy, W.E., Jr., and R.A. Peloquin, Pacific Northwest Laboratory, Richland, WA

Residual Radioactive Contamination from Decommissioning - Technical Basis for Translating Contamination Levels to Actual Dose - Draft Report for Comment

NUREG/CR-5512; PNL-7212; 320 pp. (1990, January)

This document describes the generic modeling of the total effective dose equivalent (TEDE) to an individual in a population from a unit concentration of residual radioactive contamination. Radioactive contamination inside buildings and soil contamination are considered. Unit concentration
TEDE factors by radionuclide, exposure pathway, and exposure scenario are calculated. Reference radiation exposure scenarios are used to derive unit concentration TEDE factors for about 200 individual radionuclides and parent-daughter mixtures. For buildings, these unit concentration factors list the annual TEDE for volume and surface contamination situations. For soil, annual TEDE factors are presented for unit concentrations of radionuclides in soil during residential use of contaminated land and the TEDE per unit total inventory for potential use of drinking water from a groundwater source. Because of the generic treatment of potentially complex groundwater systems, the annual TEDE factors for drinking water for a given inventory may only indicate when additional site data or modeling sophistication are warranted. Descriptions are provided of the models, exposure pathways, exposure scenarios, parameter values, and assumptions used. An analysis of the potential annual TEDE resulting from reference mixtures of residual radionuclides is provided to demonstrate application of the TEDE factors.

156

Kokaji, C., T. Abe, S. Oura, and M. Sato, Central Technical Research Institute, Sato Kogyo Company, Limited, Japan

\section{Experiment on Water Jet Method Used for Cutting Concrete Which Covers Piping}

Jet Cutting Technology, Proceedings of the Eighth International Symposium, Duram, England, September 9-11, 1986; (pp. 249-258) (1986, September 9-11)

With the progress in the application technology of high-speed jet systems and the advancement of ultra-high water pressure generating devices, the application of high-speed water jet systems has been extended to cutting of concrete and hard rocks, improvement and demolition of structures by crushing and demolition of tunnels, and it has been demonstrated that the capability of the system has been so improved that powerful cutting can be performed. This experiment was carried out on the application of water jet and abrasive jet technology to confirm whether with this method existing piping embedded in slabs on grades, floor slabs, or walls of 
various structures can be removed, repaired, or replaced without generating noise, vibration, or dust, and without the structure and/or piping itself being damaged, which are disadvantages of conventional methods. Comparison and study were also made of the water jet and abrasive jet method and conventional methods. The results of the experiment and study are reported here.

\section{7}

Komatsu, F., Kobe Steel Limited, Kobe, Japan

Method of Decontaminating Surface of Radioactive Metal Waste

Japanese Patent JP 1-295199/A/; 10 pp. (1989, November 29)

First, an organic acid solution is sprayed on the outer surface of radioactive metal wastes until the entire outer surface is wet. Spray is then applied and allowed to stand for a predetermined period of time. This procedure is repeated. Then, while spraying the organic acid solution onto the surface, the surface undergoes repeated grindings with a rotary brush. Finally, clean water is scattered over the surface to wash out the organic acid and other residue remaining in the receiving tray. By this method, it is possible to easily and effectively remove pollutants from metals in the field without requiring a particular dismantling operation. In addition, during grinding there is no danger that as dusts, radioactive materials are released resulting in pollution, since the surface oxides containing radioactive materials flow downward in the processing liquid.

\section{8}

Koop, W.N., General Electric Company, Hanford Atomic Products Operation, Richland, WA

\section{Radionuclides in an Abandoncd Reactor Facility}

HW-81300; 8 pp. (1964, March 11)

The prospect of abandoning one or more of the older Hanford, Washington, reactors has led to questions regarding the amount of radioactive material that will remain at such an abandoned facility. Specific requests wers made for estimates on the curies remaining in a retention basin, in a storage basin, and in a reactor core. The purpose of this report is to provide these estimates and show how they were computed. Radioanalyses of retention basin sludge samples previously indicated that the principal radionuclide was zinc-65, with some relatively minor quantities of fission products. Settled radioactive debris in the storage basins are fission products. Less is known about the kind of radioactive materials in a reactor core.

159

Kruger, F.W., H. Rabold, and H. Arndt, National Board for Atomic Safety and Radiation Protection, Berlin, German Democratic Republic

Particulars of Regulatory Practice for Nuclear Power Plants in the German Democratic Republic

Regulatory Practices and Safety Standards for Nuclear Power Plants, Proceedings of an International Symposium, Munich, Federal Republic of Germany, November 7-10, 1988, 583 pp.; (pp. 137-146) (1989, November 10)

In the German Democratic Republic, the use of nuclear energy is based on the Atomic Energy Act and governmentally controlled by the National Board for Atomic Safety and Radiation Protection. The board has no responsibility for the promotion of nuclear encrgy uses. It is exercising its control functions by licensing and surveillance, taking into account the findings of other governmental authorities. In conformity with the International Atomic Energy Agency Nuclear Safety Standards (NUSS) requirements, licenses are granted for the siting, construction, commissioning, operation, and decommissioning of a plant. The German Democratic Republic is an importer of major nuclear power plant components for which criteria and standards of the supplier may be accepted in the licensing procedure. In recent years the Council for Mutual Economic Assistance countries have launched a broad program for the development of detailed safety criteria and standards for nuclear power plants. National regulations largely correspond with NUSS documents and other international standards and recommendations. The 
board has to control the qualifications of the personnel responsible for tasks of relevance to atomic safety and radiation protection and to provide special training in this area.

160

Kurnosov, V.A., V.M. Bagryanskii, and I.K. Moisecv

\section{Entombment of Chernobyl Unit 4}

Soviet Atomic Energy (8810):299-306 (1988)

The task of efficiently building the "Shelter" structure for the damaged Unit 4 of the Chernobyl plant has been successfully solved. This paper describes the initial data used to build the "Shelter" structure; basic problems in designing the structures; construction decisions; and the results of erecting the "Shelter" structure.

\section{1}

Lambert, I., A. Le Duigou, M. Poupard, P. Michaille, A. De Santis, and C. Grasso, Societe Francaise d'Energie Nucleaire, Paris, France

Basic Rescarch on Decontamination Processes

CONF-881009; LIMET 88: Liquid Metal Enginecring and Technology, Proceedings of an International Conference, Avignon, France, October 17-21, 1988, Vol. 1, 524 pp.; (pp. 306.1-306.9) (1988)

Although decontamination of LMFBRs primary components are currently performed, basic research is still necessary to fulfill particular requirements. For Phenix and Super Phenix (SPX), there is still a need for finding solutions that could decontaminate the sensitized parts of the intermediate heat exchangers (IHXs) without causing intergranular corrosion (IGC) and avoiding the presence of phosphate, the release of which is being more and more strongly regulated. The results of the new solution discovered and tested in the SECA laboratory for this purpose is first described in this paper and compared with other decontaminating solutions. Other components (like the pumps) present a variety of materials, certain of which carnot suffer such aggressive solutions. In Italy, the decontamination of the fuel charge machine of the
PEC reactor, in the assembly of which various alloys are used, is of primary concern. The results concerning the various tests performed are given in the second part of the paper.

162

Large, J.H.

Factors Influencing the Decorimissioning of Large-Scale Nuclear Plants: Magnox Nuclear Power Stations

Decommissioning of Nuclear Facilities, Proceedings of an International Seminar, London, United Kingdom, July 6-7, 1988; (6 pp.) (1988, July 7)

With respect to the final decommissioning of a large-scale nuclear plant, the nuclear industry does not know quite how to do it, when it will be attempted, and when it will be completed. They also do not know how much it will eventually cost. Hence for the Magnox reactors, deferred decommissioning is the preferred option.

\section{3}

Lasch, M., Bundesministerium fuer Umwelt, Naturschutz und Reaktorsicherheit, Bonn, Federal Republic of Germany

\section{Radiological Safety Aspects of Decontamination Methods - Decontamination Method Applied in the Decommissioning of the Gundremmingen Nuclear Power Station}

CONF-8611297; Radiation Protection Principles for Management of Solid Radioactive Waste, Proceedings of a Closed Meeting of the Strahlenschutzkommission, Gundremmingen, Federal Republic of Germany, November 6-7, 1986, Vol. 11, 223 pp.; (pp. 93-108) (1988)

The paper explains the decontamination method that combines electrochemical decontamination with the use of phosphoric acid, and has proven to be an easy, fast, and reliable method. Phosphoric acid recycling is a state-of-the-art technique by now and keeps the amount of secondary wastes to an excmplarily low level. The method described thus is very suitable for fast and easy decontamination work for unrestricted 
release of materials. It also is an inexpensive method at that when applied for preliminary, fast decontamination of material destined for melt down and subsequent return to controlled arcas.

\section{4}

Laverie, M.

\section{Licensing Authority Experience and Policy for Decommissioning of Nuclear Installations}

CONF-891077; Decommissioning of Nuclear Installations, Proceedings of the 1989 International Symposium, Brussels, Belgium, October 24-27, 1989. Commission of the European Community, Brussels, Belgium; (pp. 1-7) (1989)

Under French regulations, the decommissioning of nuclear installations is covered by the same general provisions applicable to the creation, modification and operation of all nuclear installations. Indeed, it is not of a different nature other than installations (such as for example a production unit on which maintenance or modification work is carricd out, or a nuclear waste temporary repository). In this discussion, the proposal is to describe different technical stages which, within the framework of French practice, result in the decommissioning levels as defined by the IAEA, and it shall be shown how the regulations establish a general framework enabling the safety authority to carry out the necessary authorization procedures. A bricf summary shall be made of the experience acquired in France with the decommissioning of nuclear reactors of different sizes and the decommissioning of fuel cycle installations.

\section{5}

Lazo, E.N., Brookhaven National Laboratory, Upton, NY

The TMI-2 (Three Mile Island Unit 2) Reactor Building Gross Decontamination Experiment Effects on Loose-Surface Contamination Levels

CONF-881011; Proceedings of a Joint European Nuclear Society and American Nuclear Society Meeting, Washington, DC, October 30-November 4, 1988; (pp. 455-456);
Transactions of the American Nuclear Socicty 57:455-456 (1988)

In March 1982, the Gross Decontamination Experiment was conducted in the Three Mile Island Unit 2 (TMI-2) reactor building. The intent of the experiment was twofold: (1) to determine which of several commonly used decontamination techniques would be the most efficient at reducing contamination levels on vertical and horizontal surfaces and (2) to actually reduce radiation and surface contamination levels in the accessible areas of the reactor building in order to reduce person-rem expenditures for future entries. Accessible areas included the entire reactor building except inside the D-rings, inside the enclosed stairwell, and at the elevation of $282 \mathrm{ft}$. The experiment was broken into six separate tasks, implemented by nine different work packages, and accomplished during 15 reactor building entries over a 30-day period. Approximately 40 person-rem were expended in completing the experiment. While the results of the experiment did show which decontamination techniques were the most effective, loose surface contamination and radiation levels in the reactor building were not substantially reduced. The decontamination techniques tested and the key test parameters are shown.

\section{6}

Le Garreres, I., G. Pilot, M. Pourprix, J. Vendel, and M.W. First, Institut de Protection et de Surcte Nucleaire, Gif-Sur-Yvette, France; U.S. Nuclear Regulatory Commission, Office of Nuclear Regulatory Research, Washington, DC; Harvard University, Boston, MA

Improvements of Decommissioning Gascous Waste Handling by Cleaning Devices Cleaning Laboratory

NUREG/CP-0098 (Vol. 1); CONF-880815 (Vol. 1); Proceedings of the DOE/NRC Nuclear Air Cleaning Conference, Boston, MA, August 22-25, 1988; (pp. 278-287) (1989, May)

The processes of thermal cutting, because they are efficient, are often recommended and used during nuclear installation dismantling operations. But these processes emit large amounts of ultrafine 
acrosols which, if no precautions are taken, quickly clog HEPA filters in the ventilation networks. This paper pinpoints the problem in its context and presents some of the technical devices that can be considered to limit the impact of these wastes. A few examples are given about the use of decloggable prefilters, and their performance in particular applications is outlined.

167

Leigh, D.W.

Good Plant Practices: A Prelude to Cost Effective Decommissioning

Nuclcar Plant Journal 7(4):86-88 (1989)

Although there is limited full scale experience with nuclear generating plant decommissioning, the decommissioning experience gained so far has provided some important lessons. Viewing decommissioning as principally a radwaste activity provides the opportunity to anticipate end-of-life programs from an operational perspective, thus enabling a more realistic grasp of the condition and some of its consequences. Awareness of this event will assist utility managers with making the right decisions at the right times. A utility that arrives at the end of plant's useful life with accurate, well documented facts about its activities and their environmental impact and the knowledge that all radwaste decisions have included an organized appraisal of material and equipment to be deferred to post operational disposal should be in a position to accomplish a cost effective end-of-life program that will have few surprises.

\section{8}

Loercher, G., Bundesministerium fuer Umwelt, Naturschutz und Reaktorsicherheit, Bonn, Federal Republic of Germany

\section{Radioactivity Inventories in the Decommissioned Nuclear Power Plant}

CONF-8611297; Radiation Protection Principles for Management of Solid Radioactive Waste, Proceedings of a Closed Mecting of the Strahlenschutzkommission, Gundremmingen,
Federal Republic of Germany, November 6-7, 1986, Vol. 11, 223 pp.; (pp. 57-72) (1988)

Assessment of the radioactivity of activated areas or equipment (fucl elements, filter residues, and contaminated plant components) is done by measurement supplemented by calculations. Whereas measured values for well measurable radionuclides may in some instances correct the calculated values, calculations allow more simple assessment of a significantly broader spectrum of nuclides. The author briefly explains the calculations done for unit $A$ of the Biblis reactor and the Brunsbuettel reactor and for the SNR-300 and the THTR-300, and discusses the radioactivity inventories determined in the Lingen reactor and the RWE-Bayernwerk reactor, unit A.

\section{9}

Loeschhorn, U., Bundesministerium fuer Umwelt, Naturschutz und Reaktorsicherheit, Bonn, Federal Republic of Germany

Revicw of Nuclear Power Plants That Have Been or Will Be Decommissioned Decommissioning Work Carried Out for $\mathrm{KKN}$, FR-2, and MZFR

CONF-8611297; Radiation Protection Principles for Management of Solid Radioactive Waste, Proceedings of a Closed Mecting of the Strahlenschutzkommission, Gundremmingen, Federal Republic of Germany, November 6-7, 1986, Vol. 11, 223 pp.; (pp. 23-35) (1988)

At its technical committee meeting in 1982, the International Atomic Energy Agency (IAEA) defined three decommissioning stages after shutdown of a nuclear facility. The stages are defined almost exclusively with regard to the radiological conditions. In the Federal Republic of Germany, these decommissioning principles have been supplemented by definition of additional measures referring to plant structures; as for example, alternative use of buildings or partial dismantling. The decommissioning work carried out for the nuclear facilitics $\mathrm{KKN}, \mathrm{FR}-2$, and MZFR is reviewed in order to show the practical aspects connected with the three decommissioning stages. 
170

Loeschhorn, U., Kernforschungzentrum Karlsruhe, Karlsruhe, Federal Republic of Germany

Decommissioning Plans and Programs in the Federal Republic of Germany

Decommissioning of Nuclear Facilities, Proceedings of an International Seminar, London, United Kingdom, July 6-7, 1988; (10 pp.) (1988, July 7)

At present in the Federal Republic of Germany, seven reactors of different types are at various stages of decommissioning. They include plants which have already been decommissioned to the safe enclosure condition (IAEA stage 2) and plants currently being taken to stage 2. Work on the KKN plant at Niederaichbach is on schedule for complete dismantlement (IAEA stage 3) and return to green field conditions within the next five years. The author gives a summarized overview on the progress of these projects. The author also describes research and development activities by private companies on decontamination, concrete blasting, explosive pipe cutting, manipulator control, and stcel melting scrap.

\section{1}

Loeschhorn, U., and K. Wirtz, Kernforschungzentrum Karlsruhe, Karlsruhe, Federal Republic of Germany

\section{Preface - Decontamination and Decommissioning}

Nuclear Technology 86(2):97 (1989, August)

This short article is the introduction to a special issue of the Nuclear Technology journal dealing with decontamination and decommissioning (D\&D) of nuclear facilities. The article briefly discusses in general the problems confronted in global $D \& D$ efforts.

172

Lorin, C., R. Rouvicre, and G. Pilot
Adaption of High-Pressure Water Jets and Abrasives to Dismantlo Nuclear Installations

CONF-891077; Decommissioning of Nuclear Installations, Procecdings of the 1989 International Symposium, Brussels, Belgium, October 24-27, 1989. Commission of the European Community, Brusscls, Belgium; (pp. 230-241) (1989)

The application of cutting processes by water jets and abrasives during the dismantling of nuclear installations, necds adaptations, an evaluation of produced nuisances and the inspection of its possibilities. The work applied this cuiting process to different samples of stecl and concrete with telemanipulators. The work on the cutting process by water and abrasive jets for the dismantling of nuclear installations has been realized in connection between Hanover University and CEA; the first making basic studies for the application on stecl samples under water, the second operating in air automatically for the cutting of large samples of concrete and steel. The two partners are in good agreement on the result for the cutting performance: there is an optimum for the proportion of water and abrasive, mass flow and the best way is 10 use a nozzle with a hole of $0.46 \mathrm{~mm}$ diameter and high pressure to obtain a good efficiency and also a minimum waste gencration. Actually the water abrasive jet equipment, used to cut stecls, and reinforced concretes is operational and all required work techniques are being perfected, but work still remains for using this tool in remote operation.

173

Masaki, N.M., T. Hirabayashi, and M. Sacki, Japan Atomic Energy Rescarch Institute, Tokai Rescarch Establishment, Department of Japan Power Demonstration Reactor, Tokai, Ibaraki, Japan

Study on Sorption of Tritium on Various Material Surfaces and Its Application to Decontamination of Tritium-Sorbing Materials

Fusion Technology 15(2):13.37-1342; Technology of Fusion Energy, Procecdings of the Eighth 
Topical Mecting, Salt Lake City, UT, October 9-13, 1988; (pp. 1337-1342) (1989, March)

The behavior of sorption of tritium on surfaces of stainless stecl, aluminum, and borosilicate glass has been studied using gaseous tritium with high specific activity. This newly obtained knowledge has been applied to chemical and thermal decontamination of tritium-sorbing materials. The sorption behavior depends on the surface character of each material. The total amount of sorbed tritium is evaluated as a function of the time of exposure to gaseous tritium. The depth profile of sorbed trittum is obtained by the chemical etching method. From these results, practical samples of stainless stecl were decontaminated. A vacuum bakeout for $24 \mathrm{~h}$ at 773 $\mathrm{K}$ and dissolution by dilute $(5 \%) \mathrm{HCl}$ for $2 \mathrm{~h}$ enabled the authors to obtain a decontamination factor of 200 .

174

Mazurkicwicz, M., J. Whitc, and G. Galecki, University of Missouri at Rolla, Rolla, MO

\section{A Model Study of the Water Pressure Distribution in a Crack When Impacted by a High Pressure Water Jet}

Jet Cutting Technology, Procecdings of the Eighth International Symposium, Duram, England, Septernber 9-11, 1986; (pp. 189-193) (1986)

A high pressure water jet has proven to be a very effective tool for the disintegration of materials especially those which have a blocky structure. To gain a better understanding of material disintegration, a model stlidy of water jet action on material discontinuities has been carried out and the pressure distribution inside a gap, designed to simulate a representative microcrack in the material, has been recorded. This study provides information on hydrowedge creation and high pressure jet injection into matcrials during failure. The comminution process may be defined as either a single or multistage process during which mincral ores or other materials are reduced from a variety of original sizes by various crushing processes, to a narrowly defined product size range required for subsequent processing. Current comminution technology is both energy intensive and incfficient. Up to $99 \%$ of the encrgy consumed during the operation of conventional size reduction devices goes into nonproductive work, with only $1 \%$ of the enorgy input avallable to creato new surfaces in the fragmentation process. Comminution is thus an appropriate target for significant energy savings, since the tonnages of materials involved in the size reduction operations are so great that even small improvements in comminution efficiency would provide considerable savings in energy.

\section{5}

McGough, M.S., W.E. Austin, and G.J. Knetl, PCI Energy Services, Lake Bluff, IL; GPU Nuclear Corporation, Parsippany, NJ

\section{Underwater Plasma Arc Cutting in Three Mile Island's Reactor}

Welding Journal (8907):22-27 (1989, July)

The lower-core support assembly (LCSA) of the TMI-2 reactor was not structurally damaged in the March 28, 1979, partial fucl-melt accident. In order to permit defueling of that region of the reactor core, the LCSA was plasma-arc cut to permit access to the corc. A five-axls teleoperator was developed to deliver plasma arc cutting, rotary grinding, and abrasive waterjet cutting of end effectors to the LCSA. In addition, the automated cutting equipment system (ACES) manipulator and plasma arc cutting system were used for vertical sectioning of the baffle plates. ACES and the end effectors were designed, fabricated, tested, and implemented in the ficld by PCI Energy Services of Lake Bluff, Illinois. Complex geometry sectioning was completed in a mock-up facility at chemistry and pressure conditions simulating those of the reactor vessel, prior to actual in-vessel operations. In-vessel activities began in early May, 1988, and were completed on April 11, 1989. This paper presents the details of the in-vessel cutting efforts.

\section{6}

McIntosh, T.W., W.W. Bixby, J.E. Krauss, and D.R. Lcap, U.S. Department of Energy, Washington, DC; U.S. Department of Encrgy, West Valley Demonstration Project Office, West 
Valley, NY; West Valley Nuclear Services Company, Inc., West Valley, NY

\section{An Overvicw of Waste Management Systems at the West Valley Demonstration Project}

CONF-880201; Waste Management '88: Waste Processing, Transportation, Storage and Disposal - Technical Programs and Public Education, Post, R.G. (ed.), Proceedings of a Conference, Tucson, AZ, February 26-March 3, 1988, Vol. 2, 1052 pp.; (pp. 785-790) (1988)

The West Valley Demonstration Project's main objective is to solidify approximately two million liters of high-level radioactive liquid waste into a form suitable for transport to a federal repository for final disposal. The majority of the liquid waste was produced as a by-product of the Purex extraction process and is stored in an underground stecl tank. A waste characterization program has shown that the neutralized waste has settled into two distinct layers: a clear alkaline liquid (supernatant) layer and a dense precipitate (sludge) layer. The principle radioactive elements in the waste are cesium-137 (supernatant) and strontium-90 (sludge). A Supernatant Treatment System has been designed and constructed to concentrate the radioactive cesium onto an inorganic zeolite exchange medium which will reduce the volume of the final waste form (borosilicate glass) by a factor of six. The decontaminated salt solution from the STS will be processed as a low-level waste product by the Radwaste Treatment System (RTS), which consists of three major subsystems, the Liquid Waste Treatment System (LWTS), the Cement Solidification System (CSS) and the RTS Drum Cell. The LWTS is designed to concentrate the decontaminated supernatant to 39 percent solids by evaporation. The evaporated concentrates will be transferred to the CSS for solidification in cement. The CSS is a remote cement mixing and drum handling system designed to fill 269-liter square drums or 208-liter round drums at a rate of 100 drums a day. The drums will be stored on-site inside the RTS Drum Cell, which is a shiclded, weatherproof structure. This paper describes the overall project strategy, the waste management systems, the present project engineering and construction status, and the project schedule leading to radioactive operation.
177

McIsaac, C.V., C.M. Davis, J.T. Horan, and D.G. Keefer, EG\&G Idaho, Inc., Idaho Falls, ID

Results of Surface Activity and Radiation Ficld Measurements Made During Surface Decontamination Experiments Conducted at TMI-2

CONF-8507160; Fission Product Bchaviour and Source Term Research, Proceedings of an American Nuclear Socicty Meeting, Snowbird, UT, July 15, 1985; (pp. 61.1-61.17) (1985)

The loss of coolant accident at TMI-2 exposed about 22000 square meters of concrete and metal surfaces within the reactor building to liquid and vapor-phase radionuclide contamination. During the course of the accident, floors and walls of the auxillary fuel handling building were also contaminated. Since 1981 the decontamination of these surfaces has been conducted using water spray, strippable coating, and scabbling techniques. These decontamination studies have helped determine the distribution of radionuclides on building surfaces and the nature of the radionuclide penetration into surface coatings. In addition, in situ radiological surveys of decontamination effectiveness were performed. This paper reviews the results of these surface decontamination studies and presents conclusions on the nature and extent of reactor building contamination as a consequence of the TMI-2 accident.

178

Miller, C.L.

Environmental Assessment and Finding of No Significant Impact Regarding Proposed Order Authorizing Dismantling of the Reactor and Decomposition of Component Parts: Michigan State University

Federal Register 54(129):28740 (1989, July 7)

The Nuclear Regulatory Commission (NRC) is considering issuance of an Order authorizing the Michigan State University (licensec) to dismantle the TRIGA Nuclear Reactor in East Lansing, Michigan and 10 dispose of the reactor components in 
accordance with the application dated January 20, 1989, as supplemented on May 4, 1989. By this application, the licensec requested authorization to dismantle the $250 \mathrm{~kW}$ (thermal) Michigan Statc University Rescarch Reactor (MSURR), to dispose of lts components parts and radioactive material, and decontaminate the facility in accordance with the proposed dismantling plan, and to torminate facility license No, R-114. The MSIJRR was shut down in October 1987, and has not been operated since then.

179

Miller, C.L.

Environmental Asscassment and Finding of No Significant Impact Regarding Proposed Order Authorizing Phaso 2 Dismantling of the Reactor and Disposition of Component Parts: The University of California at Los Angeles

Federal Register 54(143):31266-31267 (1989, July 27)

The Nuclear Regulatory Commission is considering issuance of an Order authorizing the University of California at Los Angeles (UCLA) to complete dismantlement of the UCLA Argonaut Reactor Facility on its campus in Los Angeles, California and to dispose of the reactor components in accordance with the application dated Junc 10, 1988 as supplemented or. June 21, 1988, December 7, 1988 and March 31, 1989.

\section{0)}

Miller, C.L., and W.F. Heine, U.S. Department of Encrgy, Richland Operations Office, Richland, WA; Westinghouse Hanford Company, Richland, WA

\section{Defense Decontamination and Decommissioning Program}

DOE/RL-88-()3; 89 pp. (1989, February)

In 19\%8, under authority of the Atomic Energy Act, the U.S. Department of Encrgy (DOE) established the Surplus Facilities Management Program (SFMP) to cnsure the safe caretaking and decommissioning of both Civilian and Defense "orphan" (no longer part of any currontly funded oporating program) surplus facilities. The inventory of the SFMP includes approximately 300 facilities requiring remedial action. The facilities include production and test reactors, chemical processing plants, waste treatment disposal systems, laboratories, and various support facilities. The remedial actions planned for these facilities range from the decontamination of facilities with the potential lor reuse, to the complete dismantlement of structures and site restoration to allow unrestricted use. This overview presentation is on the SFMP Defense Decontamination and Decommissioning (D\&D) Program, which includes only shutdown DOE-owned facilities used in national defense programs. Included in this presentation are descriptions of the seven Defense D\&D program sites, and descriptions of some of their activities.

\section{1}

Mincarini, M., Ente Nazionale per l'Energia Elettrica, Rome, Italy

Radiological Charactcrization of Nuclear Plants Under Decommissioning - Problems and Experiences

$$
\text { ENEA-RT-PAS-89-2; } 54 \text { pp. (1989) }
$$

In the present work, a description of major problems encountered in qualitative and quantitative radiological characterization of plants for decommissioning and decontamination purpose is presented. Reference to several nuclear plant classes activation and contamination processes, direct and indirect radiological analysis and some significant experiences are described.

\section{2}

Mogg, C.S., British Nuclear Fucls, Limited, Risley, United Kingdom

\section{An Overvicw of Radioactive Waste Management at Scllaficld}

CONF-880201; Waste Management '88: Waste Processing, Transportation, Storage and Disposal - Technical Programs and Public Education, Post, R.G. (cd.), Proceedings of a Conference, Tucson, AZ, February 26-March 3, 1988, Vol. 2, 1052 pp.; (pp. 281-287) (1988) 
This paper outlines the main as'nects of United Kingdom policy with regard to radioactive waste management. It defines the categories of waste arising at British Nuclear Fuels, Limited's (BNFL's) nuclear fuel reprocessing plant at Scllaficld in Cumbria and their main sources. It goes on to describe existing waste management arrangemeats at Sellafield as well as future plans for the further reduction of liquid effluent activity and the preparation of retained waste for disposal.

\section{3}

Morillon, C., J.F. Routier, and G. Pilot

\section{Thermal Techniques for Surface Concrete Decontamination}

CONF-891077; Decommissioning of Nuclear Installations, Proceedings of the 1989 International Symposium, Brusscls, Belgium, October 24-27, 1989. Commission of the European Community, Brussels, Belgium; (pp. 553-563) (1989)

When nuclear installations are decommissioned, particular attention should be paid to concrete surfaces which could be contaminated to varying depths. Based on economic considerations, different stripping and nonstripping methods could be selected depending on the depth penetration of contamination and on the types of areas. In this field, thermal techniques seem to be attractive: (1) ability of weakening the material with decp fissuration due to high temperature, (2) remove concrete by successive thin layers so as to minimize radioactive wastes, and (3) low levels of aerosol emissions. The aim of this paper is to present developments of two methods: (1) a rack-torch unit with a fast cooling system (tested by STMI), and (2) a plasma augmented burner (tested by BER'TIN in collaboration with the CEA Saclay).

184

Mosavi, R.K., Chromalloy American Corporation, Orangeburg, NY

\section{Comparing Laser and Watcrjet Cutting}

Lasers and Optronics 7:65-68 (1987, July)
This article is an enginecring and cost comparison showing how lasers stack up against waicrjet cutters in industrial applications. There are approximately the sume number of each (1000) being used for material cutting worldwide. An average growth rate of $20 \%$ per year is estimated for both systems. The author outlines the basics of both laser cutting and waterjet cutting, summarizes the costs of both systems, and concludes that laser systems are more versatile and trouble-free, while waterjet systems can cut thicker materials, do not produce hazardous gases and lumes, and interface more easily with current robotic systems.

185

Muvchan, S.V.

\section{Dismantling Operations During NPP Decommissioning}

Energeticheskoc Stroitel'stvo za Rubezhom 5:17-19 (1988, October)

Scientific, technical, technological and economical aspects of the problem of NPP decommissioning are described. The experts of International Atomic Energy Agency as well as United States, Federal Republic of Germany, and Japan estimate that NPP decommissioning costs with complete equiprnent dismantling equals and sometimes exceeds those of constructing a new NPP. The conclusion is made that considering complexity and work cost increase, it is advisable to analyze a possible prolongation of reactor service life 1.5-2 times by partial replacement of technological equipment and decontamination of structures.

\section{6}

Murav'ev, V.F., L.V. Gor'kov, and A.B. Ozolin, Gosudarstvennyj Komitet po Ispol'zovaniyu Atomnoj Ehnergii SSSR, Tsentral'nyj Nauchno-Issledovatel'skij Institut Informatsii $i$, Moscow, USSR

\section{Contact Arc Cutting of Worked-Out Equipment}

INIS-SU-95; (pp. 33-37) (1988) 
Possibility of using contact-arc (electrocontact) cutting for division worked-out equipment is considered. Installations, designated for cropping such equipment are described.

187

Napier, B.A, and W.E. Kennedy, Jr., Pacific Northwest Laboratory, Richland, WA

\section{Estimated Doses from Decommissioning} Activities at Commercial Nuclear Power Stations

Transactions of the American Nuclear Society 59:44-45 (1989)

The authors review generic population dose cstimates for decommissioning reference boiling water reactors (BWRs) and pressurized water reactors (PWRs) and provides extrapolated estimates of the total collective dose resulting from decommissioning commercial nuclear reactors operated in the United States. Decontamination and decommissioning of retired nuclear power reactors are a necessary part of the nuclear fucl cycle. During decommissioning of large facilities (500 to 1200 MWe), radioactivity will be encountered in activated reactor components and in contaminated piping, equipment, and building surfaces. Contaminated areas of the facility result from processing and leaks of primary coolant that contain activation products and fission products from the reactor core.

188

Niemczyk, S.J., Gull Associates, Washington, DC; Analysas Corporation, Oak Ridge, TN

Consequence Estimation for Decontaminated Sites and Facilities

CONF-881054 (Vol. 4); Proceedings of the 1988 Annual DOE Model Conference, Oak Ridge, TN, October 3-7, 1988; (pp. 1309-1320) (1988)

To aid the U.S. Environmental Protection Agency's (EPA's) sclection of decommissioning criteria for unrestricted release of cleaned up sites and facilities, a new approach has been developed for estimating the potential hazard from residual radioactivity. That apprnach, intended to provide conservatively realistic - thates of radiation doses to individual residents trom such radioactivity in the environment and in buildings, uses a comprehensive yet relatively simple set of pilysically based risk level environmental transport and exposure pathway models. Doses are estimated for up to 10,000 years. Radioactive decay and ingrowth are explicitly accounted for. Compared with some other approaches, the new approach has several outstanding features. First, some of its models are less conservative than the comparable models in other approaches. Second, the new approach includes models for estimating certain doses in multiroom buildings. Third, the approach's integrated set of transport and behavior models permits straightforward consideration of situations with significant movement of radioactivity within the environment and/or significant radioactive ingrwith. Fourth, the approach's efficient solution techniques, combined with its comprehensive set of transport and behavior models, make consideration of many situations practical. And fifth, the associated computer code runs on a personal computer. The new approach constitutes a significant first step toward a set of comprehensive relationships for providing dose and health risk estimates for residual radioactivity at a variety of sites and facilities.

\section{9}

Nuclear Energy Agency, Paris, France

\section{NEA International Co-Operative Projects}

INIS-XN-183; 38 pp. (1989)

This text is concentrated on the international co-operative projects of the OECD Nuclear Energy Agency (NEA) in the field of reartor safety (Halden reactor project, Loft project, studies on the damaged Three Mile Island Unit 2 reactor, inspection of reactor stecl components, and incident reporting system) and in the field of radioactive waste management (Stripa project, geochemical data bases. Alligator river project, seabed disposal of high-level radioactive waste, and decommissioning of nuclear facilities). 
190

Obst, H., Bundesministerium fuer Umwelt, Naturschutz und Reaktorsicherheit, Bonn, Federal Republic of Germany

\section{Mechanical Dismantling and Breakdown Methods}

CONF-8611297; Radiation Protection Principles for Management of Solid Radioactive Wastc, Proceedings of a Closed Meeting of the Strahlenschutzkommission, Gundremmingen, Federal Republic of Germany, November 6-7, 1986, Vol. 11, 223 pp.; (pp. 137-141) (1988)

The selection of mechanical dismantling and cutting methods instead of thermal cutting by grinding, for example, is a decision taken for reasons of radiological safety, in order to prevent entrainment of radioactivity. Radiological protection is one of the main reasons leading to application of mechanical methods for dismantling, as the thermal dismantling and thermal grinding methods produce dust and other debris that are a hazard to the personnel, not only due to the radioactivity. Mechanical dismantling work does not require protective means such as tents or hoods.

\section{1}

Ogata, Y., J. Ohuchi, E. Inada, and N. Tsunoda, Power Reactor and Nuclear Fuel Development Corporation, Tokai, Ibaraki, Japan

\section{Processing at the Plutonium-Contaminated} Waste Treatment Facility

Management of Low and Intermediate Level Wastes, Proceedings of an Intcrnational Symposium, Stockholm, Sweden, May 16- 20, 1988, Vol. 1, 457 pp.; (pp. 325-329) (1989)

The Power Reactor and Nuclear Fuel Development Corporation (PNC) completed the construction of the Plitonium-Contaminated Waste Treatment Facility (PWTF) at its Tokai Works in August 1987 and put it into hot operation. The purpose of the facility is to demonstrate techniques for volume reduction of the plutonium-contaminated solid wastes generated from the MOX fuel fabrication facilities. The plant is $68 \mathrm{~m} \mathrm{long,} 30 \mathrm{~m}$ wide, and 27 $\mathrm{m}$ high and has a total floor area of about $7200 \mathrm{sq} \mathrm{m}$. The plant consists of three floors above and one floor below ground. On the basis of PNC's R\&D results, the PWTF was designed to incorporate several unit processing operations in large glove boxes (total volume $700 \mathrm{sq} \mathrm{m}$ ), such as waste reception, sorting, incincration, acid digestion, metal melting, ash melting, and liquid waste treatment. The throughput is $2.5 \mathrm{sq} \mathrm{m} / \mathrm{d}$, or $450 \mathrm{sq} \mathrm{m} / \mathrm{d}$ based on 180 days of operation, and the total volume reduction factor is 20 .

192

Oh, W.Z., H.J. Won, H.P. Kim, C.H. Jung, S.Y. Park, J.B. Shim, C.H. Cho, and W.K. Choi, Korea Advanced Energy Research Institute, Darduk, Republic of Korea

\section{Decontamination and Decommissioning Technology Development of Nuclear Facilitics}

$$
\text { KAERI/RR-798/88; 200 pp. (1989, February) }
$$

Removal behavior o" an oxide which is similar in structure and composition to that on the internal system of a steam generator was investigated in a low concentration chemical decontamination process (KAERI process). In the AP solution (oxidative dissolution step), chromium dissolved very fast from the oxide in the early stage and then dissolved very slowly in the later stage. Dissolution bchaviors of iron from the oxides in the reductive dissolution process were similar to those of chromium in the oxidative dissolution process. Oxide dissolution bchavior in each process were discussed. In the twice-cyclic application of the oxidative and the reductive dissolution process (KAERI decontamination process), about $50 \%$ of the oxide was removed by chemical dissolution and about $40 \%$ by particulate detachment. The remaining $10 \%$ of the oxide could be completely removed by ultrasonic decontamination. A corrosion acceptance guideline was established for the decontamination of domestic PWRs' steam generator. In the KAERI decontamination process, gencral corrosion to an Inconel-600 and 304 stainless steel was about 2.4 and $1.0 \%$ of general corrosion limit, respectively. Localized corrosion was not observed. Those results indicated that the KAERI decontamination process assured integrity of KNUs' steam generator. To 
decommissioning of nuclear facilitics, general calculation methods of radioactive inventory, calculation and measurement of contact exposure rate, and confirmation of those results were reviewed. Feasibility for application of the above methods was examined by taking examples of radioactive inventory estimation in the Shippingport nuclear reactor vessel.

193

Oshima, H., H. Miyo, K. Kashiro, and T. Asano, Power Reactor and Nuclear Fuel Development Corporation, Tokai, Ibaraki, Japan; Japan Atomic Energy Research Institute, Tokai Research Establishment, Department of Japan Power Demonstration Reactor, Tokai, Ibaraki, Japan

Decommissioning of $\mathrm{Pu}$ Contaminated Glove Box System

Donen Giho 70:48-58 (1989, June)

The coconversion test units have been used for an engineering test of a coconversion process with a microwave direct denitration process since 1979. The important data and operational experience, which have been collected by the operation of the units during those 9 years, were very useful in the design and operation of the Plutonium Conversion Development Facility. Coconverted power ( 0.8 ton plutonium) had been fed as raw materials of "Joyo" and "Fugen" fuels. After 9 years of operation for these test units, the main process equipment and glove boxes are out of date. The test units were decommissioned from January 1988 to January 1989. Plutonium contamination in glove boxes was the highest and total volume of glove boxes was the largest compared with past experiences on the decommissioning of glove boxes. Many new and/or improved methods were applicd to this decommissioning. It was conipleted not only with a decrease of personal exposure and waste volume but also without any trouble.

194

Pachner, J., and S. Novak, Atomic Energy Control Board, Ottawa, Ontario, Canada;
International Atomic Energy Agency, Vienna, Austria

Proposed IAEA Programme on Safety Aspects of Nuclear Power Plant Aging and Life Extension

INFO-0284; CONF-880824; Nuclear Power Plant Aging, Proceedings of an International Symposium, Bethesda, MD, August 30-September 1, 1988; (5 pp.) (1988, October)

This paper provides information on the proposed International Atomic Energy Agency (IAEA) program on safety aspects of nuclear power plant (NPP) aging and NPP life extension, as recommended in June 1988 by the Advisory Group organized by the IAEA.

195

Pasqualetti, M.J.

Introducing the Geosocial Context of Nuclear Decommissioning - Policy Implications in the US and Great Britain

Geoforum 20(4):381-396 (1989)

Decommissioning is the inevitable final phase in the life of a nuclear power plant. Research and development to date have been largely technical in nature, despite the substantial past importance of geosucial issues such as emergency preparedness and transboundary pollution. Thus far public inputs have been minor and without measurable effect. Public recognition and the potential for public impact on decommissioning policy is increasing in both countries, although government agencies and utilities are taking little account of it. This article uses experience in the U.S. and in Great Britain to address the question of what the geosocial context of nuclear decommissioning is, and how this context will affect nuclear policy.

196

Pasqualetti, M.J.

Decommissioning at Ground Level - Sizewell and the Uncertainties of Faith

Land Use Policy (8801):45-61 (1988, January) 
The development of nuclear puwer is based on a faith which the public places in technology to solve all problems. Decommissioning of nuclear power plants will be the next leap the public is asked to make. This article uses evidence from the Sizewell Inquiry to identify generic and geosocial decommissioning uncertainties and discusses them within a policy and research framework. Six conclusions are advanced: (1) social uncertainties will not be resolved within a technical context alone; (2) decommissioning costs are underestimated; (3) most decommissioning decisions must be made on a case-by-case, not generic, basis; (4) decommissioning should be included routinely in local land planning decisions; (5) further nuclear development should await decommissioning experience; and (6) decommissioning should be included in all future nuclear policy decisions.

\section{7}

Passant, F.H., Central Electricity Generating Board, London, United Kingdom

\section{The Waste Management Implications of Decommissioning}

Decommissioning of Nuclear Facilities, Proceedings of an International Seminar, London, United Kingdom, July 6-7, 1988; (13 pp.)

Decommissioning policy can be framed in light of radioactive waste management policy. What can be done with the waste materials, how and when, will determine the overall decommissioning plans and costs. The waste management options and their costs are reviewed for the decommissioning of the Central Electricity Generating Board's civil nuclear power stations. The author concentrates on the decommissioning of Magnox stations, although comparative information on waste volumes and costs are given for the advanced gas-cooled reactor program and a typical pressurized water reactor.

\section{8}

Pater, L.L., Briggs Technology, Inc., Pittsburgh, PA
The Blowdown Water Cannon - A Novel Method for Powering the Cumulation Nozzle

Jet Cutting Technology, Proceedings of the Eighth International Symposium, Duram, England, September 9-11, 1986; (pp. 203-210) (1986)

The cumulation nozzle can produce a transient liquid jet that has extremely large peak velocity. Cumulation nozzle flow has been studied extensively by a number of investigators and is well understood. The following is a brief description. The term "cumulation" here means the redistribution of the kinetic energy of a discrete slug of liquid so that most of the kinetic energy is concentrated into a small portion of the mass of the slug. This occurs when an energetic slug of liquid enters the larger end of an initially empty converging nozzle passage. As the slug flows through the nozale passage, the forward portion of the slug speeds up while the rearward portion slows down because total kinetic energy is constant at best (actually some portion of the kinctic encrgy is converted to heat by friction). A suitably contoured nozile can yicld an extremely high peak exit velocity; the mass and duration of the high velocity portion of the jet will consequently be small since the total kinetic eneriy is limited. Such pulse jets have been demonstrated experimentally to be very effective in breaking hard strong targets such as rock and concrete.

199

Pavlik, O., International Atomic Encrgy Agency, Vienna, Austria

Decontamination of Nuclcar Facilitics by Electrochemical Methods

IAEA-TECDOC-511; (pp. 55-6.3) (1989, Junc)

Work was reported on electrochemical decontamination methods for maintenance of the Paks nuclear power plants in Hungary. For in situ decontamination of large components (c.g., main circulating pump, gate valves, and steam gencrator collectors), methods using remotely operated movable electrodes were implemented successfully. For the main circulating pump, the electrolyte contained phosphoric, sulfuric, and oxalic acids. The concentration of the radioactive isolopes and 
liters of liquid radioactive waste (together with rinsing water) was produced during the decontamination procedure. The duration of the decontamination was 6 to $8 \mathrm{~h}$. The procedure was carried out by 3 to 4 workers, their collective dose was 2 to $3 \mathrm{mSv}$. The decontamination was followed by chemical and radiometric analyses.

\section{0}

Pegg, I.L., W.P. Freeborn, and P.B. Macedo, Catholic University of America, Vitreous State Laboratory, Washington, DC

\section{A Process Model for West Valley Waste Vitrification}

CONF-880201; Waste Management '88: Waste Processing, Transportation, Storage and Disposal - Technical Programs and Public Education, Post, R.G. (ed.), Proceedings of a Conference, Tucson, AZ, February 26-March 3, 1988, Vol. 2, 1052 pp.; (pp. 797-804) (1988)

The authors show how, using reasonable assumptions, a simple model for the West Valley Demonstration Project (WVDP) vitrification process can be constructed. Well-developed statistical ideas are then used to determine the consequences, first in terms of glass product composition, and then in terms of glass properties, and of the expected variations in process control variables. The process region is defined and, by requiring that this lies entirely within the region of acceptable glasses, we arrive at the present WVDP reference composition, WVW-RG4. To the extent that the assumptions we have made are valid, a point that will be tested at WVDP, we concluded that WVDP, as presently characterized, can successfully produce glasses that are both processable and of acceptable durability.

201

Petrasch, P., and J. Roger

The Decommissioning Data Bank (DDB) Methodology and Applications

CONF-891077; Decommissioning of Nuclear
Installations, Proceedings of the 1989 International Symposium, Brussels, Belgium, October 24-27, 1989. Commission of the European Community, Brussels, Belgium; (pp. 75-84) (1989)

The objective of the work program is to develop a concept of data bank for evaluating decommissioning cost and radiation exposure on the basis of existing data. In the first step we have defined a methodology for extrapolating experience relating to cost and occupational radiation exposure, gained in the decommissioning of specific installations (e.g. pilot dismantling projects), to the future decommissioning of various installations. In the second step, there is collection of existing and available basic data. To date a host of results has been obtained and experience gathered under the research and development projects on the decommissioning of nuclear power plants initiated and funded by the European Community. Generally, this knowledge is passed via publications. However, handling this information and using the data, in this form, as a basis for projections and extrapolations is very time-consuming. Accessibility of the data can te considerably facilitated by establishing a database. This database enables the user to find answers to specific questions within a very short time or to get a general overview.

\section{2}

Pezzimenti, D.M., P.M. Vlad, and B. Landau, West Valley Nuclear Services Company, Inc., West Valley, NY

The Use of the Deep Kerfer for Thick, Stecl-Reinforced Concrete Cutting

DOE/NE/44139-58; 38 pp. (1989, August)

This paper describes the project at West Valley in which cutting operations were performed on thick, steel-reinforced concrete structures using the Deep Kerfer System. The project involved making modifications to the Equipment Decontamination Room, a cell in the former nuclear fuel reprocessing plant, as one phase of the Vitrification Facility Construction. 
203

Philbin, J.S., J.H. Saloio, and J. Rollstin, U.S. Nuclear Regulatory Commission, Division of Low-Level Waste Management and Decommissioning, Washington, DC; Sandia National Laboratories, Albuquerque, NM

Economic Risk of Contamination Cleanup Costs Resulting from Large Nonreactor Nuclear Material Licensee Operations

NUREG/CR-5381; SAND-89-1302; 176 pp. (1990, March)

Several potential incident scenarios involving the accidental release of radioactive material at five reference, nonreactor nuclear material licensees are analyzed in this report. The economic risk (dollars/licensee/year) of decontamination is evaluated for each reference licensee. Although most releases and cleanup costs are minor, some less-frequent incidents may result in very high cleanup costs that dominate the economic risk of decontamination of a particular licensec. The economic risk for the five plants ranged from a low of $\$ 14,000$ per licensee per year to a high of $\$ 104,000$ per licensee per year. This report is the second of two reports by Sandia National Laboratories on the economic risk of nonreactor nuclear material licerssee operations.

\section{4}

Pick, M.E., International Atomic Energy Agency, Vienna, Austria

Summary of Work on Characterization of the Radioactive Deposits on PWR Primary Circuit Surfaces

IAEA-TECDOC-511; (pp. 79-92) (1989, June)

In examining decommissioning strategies for LWRs and the possible role of decontamination, characterization of the radioactive deposits on circuit surfaces is required to provide information on the radioactive inventory and the type of oxide on the surface. Knowledge of the latter will determine which is the most appropriate decontamination process to use and its potential efficiency. Results from examinations performed on a number of
Inconel 600 steam generator and stainless steel PWR specimens and also a limited number of BWR and CANDU specimens are summarized. A varicty of techniques have been utilized including: gamma spectrometry, alpha spectrometry, scanning electron microscopy, and wet chemical analysis. In addition, preliminary studies using secondary ion mass spectrometry (SIMS) have been performed. The sources of the major radionuclides present on circuit surfaces are also considered.

\section{5}

Poiricr, J.C., P. Mulcey, P. Morel, and C Vavasseur, Commissariat a l'Encrgic Atomique, Paris, France

Installation Dismantling System, Working Process and Hood Utilizable in this System

French Patent FR 2619953/A; 24 pp. (1989, March 3)

The system for dismantling an installation under a controlled atmosphere is made by a tool polluting the atmosphere, a gas blanket creating a containment zone around the tool, an extractor removing polluted gas from the zone, a purifier for the extracted gas and a controller regulating the flow of gas in the blanket and keeping the installation at constant pressure.

\section{6}

Pratapagiri, G., International Atomic Energy Agency, Vienna, Austria

Final Report on Computer Codes for Estimating the Decommissioning Cost of Nuclear Power Plants

IAEA-TECDOC-511; (pp. 31-36) (1989, June)

Work is reported on the development and enhancement of a cost estimating program (called DECOM) using a microcomputer. The program is user-friendly, menu driven, and written in the dBase III format. With the help of this program, costs can be estimated for Stage 1, Stage 2, or Stage 3 decommissioning. The program is hased on the generally accepted concept of unit cost factors. The computer program is suitable as an aid in the 
selection and planning of a decommissioning alternative. Apart from its application in the Gentilly-1 decommissioning project, the program had been used in the preparation of cost estimates for both CANDU (Canada Deuterium Uranium) and light water reactors. In order to validate the code, samples of actual cost and manhour data from the Gentilly-1 project were processed through the DECOM code. It was observed that the total costs were accurate within $20 \%$, though the costs for individual activities in some instances varied significantly due to differing project parameters.

\section{7}

Present Status and Problems of Remote Systems Technology in Nuclear Industry

Nippon Genshiryoku Gakkaishi 31(2):239-254 (1989, February)

This reports the activities of a Special Committee on Remote Systems Technology, Atomic Energy Socicty of Japan, during the period from October 1984 to September 1988. The Committee studied and reviewed the present status and problems of remote operation and maintenance in various fields of nuclear industry. Reported items are: reactor operation, reprocessing, nuclear fusion and decommissioning. It also reviews robotics and remote systems technology applied to space and marine development.

\section{8}

Puchala, R.J., A.S. Lechem, and B.M. Hawrylewicz, Indescor Hydrodynamics, Inc., Concord, Ontario, Canada

\section{Mass Concrete Removal by High-Pressure Water Jet}

Jet Cutting Technology, Proceedings of the Eighth International Symposium, Duram, England, September 9-11, 1986; (pp. 219-229) (1986)

An automated water jet system has been developed to remove concrete form parking garage slabs and bridge decks. This was accomplished after an extensive research program using a single rotating water jet installed on an experimental machine. The paper describes the basic theoretical and experimental study of hydrodynamic and kinematic parameters of the cutting jet, and the mechanical configuration of the prototype machine used during the test. With water pressure ranging from 940 to $1450 \mathrm{bar}$, and a jet power of up to $176 \mathrm{~kW}$, the kinematics of the jet, cutting angles and traverse velocities were investigated. Analysis of these parameters yielded optimum productivity and cutting efficiency of the system. The refined system was employed in underground parking structures to remove both sound and delaminated concrete. Many reinforced concrete parking garages, bridges and highways in North America and Northern Europe require major repairs due to structural deterioration. The primaty cause of damage is salt laden water which attacks the concrete directly, and penetrates causing corrosion of reinforcing steel. The corroded steel subsequently delaminates the surface of the concrete. This leads to a loss of compressive strength because of reduced concrete area, and a loss of tensile strength due to corroded steel. Spalled concrete also effects the resistance of the structure to fire.

\section{9}

Reimus, M.A.H., G.F. Piepel, and G.B. Mellinger, Pacific Northwest Laboratory, Richland, WA

\section{West Valley Glass Product Qualification Durability Studies: Effects of Composition, Redox State, Heat Treatment, and Groundwater}

CONF-880201; Waste Management '88: Waste Processing, Transportation, Storage and Disposal - Technical Programs and Public Education, Post, R.G. (ed.), Proceedings of a Conference, Tucson, AZ, February 26-March 3, 1988, Vol. 2, 1052 pp.; (pp. 819-830) (1988)

PNL is examining the effects of composition, ferrous/ferric ratio (redox state), heat treatment, and groundwater on the chemical durability of a glass proposed for solidification of West Valley nuclear waste. Several experiments have been conducted, and preliminary results are given in this paper. The results of the experiments conducted to date indicate that waste glass is more durable in groundwater than in deionized water; also, durability is affected by 
isothermal and simulated canister cooling heat treatments. However, the durability of the waste glass is not strongly affected by the variation of glass redox state. Linear mixture models were fitted to the glass compositional variation data and validated. These models may be used to predict the effects of varying specific components on the reference glass durability within the defined composition region.

210

Remark, J.F., Applied Radiological Control, Inc., Marietta, GA

\section{A Review of Plant Decontamination Methods: 1988 Update}

EPRI-NP-6169; 48 pp. (1989, January)

This document updates state-of-the-art in decontamination technology since the publication of the previous review (EPRI NP-1128) in May 1981. A bricf description of the corrosion-film characteristics is presented as well as corrosion film differences between a BWR and PWR. The generation, transportation, activation, and deposition of the radioisotopes found throughout the reactor coolant system is also discussed. The Decontamination Planning and Preparation Section describes the technical planning steps as well as the methodology that should be followed in order to select the optimum decontamination technique for a specific application. A review of a number of the decontamination methods commercialized since 1980) is presented. The basic mechanism for each process is described as well as specific applications of the technology in the field. Where possible, results obtained in the field are presented. The information was obtained from industry vendors as well as personnel at the plant locations that have utilized the technology.

\section{1}

\section{Remote Plasma Cutting on TMI Core}

Modern Power Systems (8811):32-33 (1988, November)

To accomplish a major part of the final phase of defucling the damaged Three Mile Island Unit 2 (TMI-2) reactor, GPU Nuclear has developed a computerized, remotely operated plasma arc (PAC) cutting system. Remote underwater plasma cutting has been used in the nuclear industry for decommissioning and for modifications of operating reactors, such as the St. Lucie nuclear power plant in Florida. The method was also used to dismantle highly radioactive parts of the Elk River nuclear power plant in Minnesota and the Sodium Reactor Experiment in California. Power Cutting Incorporated were contracted to work on the automated cutting equipment system (ACES) at TMI-2 in August 1986. ACES is being used to dismantle the lower core support assembly (LCSA). Approximately 40.8 tons of core debris lie within and beneath the structure. Plasma arc is the only technique considered to be capable of cutting the LCSA in a reasonable time. Main operational objectives met by ACES were to: (1) precisely position a plasma cutting torch under 9 to $12 \mathrm{~m}$ of water in areas of restricted access; (2) perform vertical, horizontal, and contoured cuts upon stainless stecl structures from 25 to $64 \mathrm{~mm}$ thick; (3) operate in a radioactive environment in highly conductive borated torch coolant water; and (4) operate within the reactor containment without generating additional radioactive waste through plasma interaction with fucl debris.

\section{2}

Research Association for Nuclear Facility Decommissioning, Tokyo, Japan

\section{Journal of the RANDEC}

Journal of the RANDEC 1(1):1-61 (1989)

Accompanying this journal issue are an English translation of the table of contents and English-translated outlines of the five feature articles: (1) Development of the Clean Cut Removal System for Contaminated Concrete; (2) Decontamination Technology Development (I) at the Waste Dismantling Facility of PNC; (3) Decontamination Technology for Reactor Decommissioning; (4) Onc-Piece Removal of a JRR-3; (5) Removal of a Acid Recovery Evaporator (273E30) at the Tokai Reprocessing Facility. The translation and outlining were done by $\mathrm{Mr}$. Nakamura, a Japanese visitor at Argonne National Laboratory in Illinois. 
213

Robertson, D.E., U.S. Nuclear Regulatory Commission, Division of Engineering, Washington, DC

\section{Radionuclide Source Term Measurements for Decommissioning Assessments}

NUREG-0975 (Vol. 6); (pp. 389-401) (1988, June)

The objective of this project is to provide an up-to-date regulatory assessment of the radiological factors, criteria and problem arcas associated with the technology, safety, and costs pertaining to reactor decommissioning and related waste disposal. This is being accomplished through a measurements and appraisal program focused in the following key areas: radiological characterization during Shippingport Station decommissioring; radiological characterization of intermediate-level wastes (highly activated reactor internal materials greater than Class C); evaluation of the accuracy of predictive activation codes and methods; and assessment of decommissioning waste disposal options.

\section{4}

Robertson, D.E., C.W. Thomas, N.L. Wynhoff, and D.C. Hetzer, Pacific Northwest Laboratory, Richland, WA; U.S. Nuclear Regulatory Commission, Office of Nuclear Regulatory Research, Washington, DC; Brookhaven National Laboratory, Upton, NY

\section{Radionuclide Characterization of Reactor Decommissioning Waste and Spent Fucl Asscmbly Hardware}

NUREG/CP-0097 (Vol. 1); CONF-8810155 (Vol. 1); Proceedings of the 16th Water Reactor Safety Information Meeting, Gaithersburg, MD, October 24-27, 1988, 561 pp.; (pp. 73-118) (1989, March)

The U.S. Nuclear Regulatory Commission (NRC) has recently enacted rules setting forth technical, safety, and financial criteria for decommissioning of licensed nuclear facilities, including commercial nuclear power stations. These rules have addressed six major issues, including decommissioning alternatives, timing, planning, financial assurance, residual radioactivity, and environmental review. Also, the rules governing disposal of low-level radioactive wastes in commercial shallow land burial facilities will be applicable to most of the wastes generated during reactor decommissioning. This study has been implemented to provide the NRC and licensees with a more comprehensive and defensible database and regulatory assessment of the radiological factors associated with reactor derommissioning and disposal of wastes generated during these activities. The objectives of this study are being accomplished during a two-phase sampling, measurement, and appraisal program using: (1) the decommissioning of Shippingport Atomic Power Station, and (2) neutron-activated materials from commercial reactors. Radioactive materials obtained from Shippingport Station and from a number of commercial stations for comprehensive radionuclide and stable element analyses are being used to assess the following important aspects of reactor decommissioning and radioactive waste characterization: (a) radiological safety and technology assessment from an actual reactor decommissioning (Shippingport); (b) radiological characterization of intensely radioactive materials (greater than Class C) associated with the reactor pressure vessel and spent fuel assembly hardware from commercial nuclear power plants; (c) evaluation of the accuracy of computer codes for predicting radionuclide inventories in retired reactors and neutron activated components; and (d) assessment of waste disposal options associated with reactor decommissioning.

\section{5}

Robinson, K.S., C. Hamblin, and M.W. First, U.S. Nuclear Regulatory Commission, Office of Nuclear Regulatory Research, Washington, DC; Harvard University, Boston, MA

Measurement and Removal of Steel Flame Cutting Acrosols (0.01-1 um) in WAGR Decommissioning Cleaning Laboratory

NUREG/CP-0098 (Vol. 1); CONF-880815 (Vol. 1); Proceedings of the DOE/NRC Nuclear Air Cleaning Conference, Boston, MA, August 22-25, 1988; (pp. 248-258) (1989, May) 
This paper gives detalls of work undertaken in support of the Advanced Gas-Cooled Reactor (AGR) decommissioning program at Windscalc Nuclear Laboratories using full-scale inactive simulation of oxy/propane flame cutting operations. Cutting fume acrosol size distributions and concentrations were measured and tests were undertaken to establish the performance of an electrostatic precipitator and reverse pulse cleaned cartridge filter as prefilters for the main ventilation HEPA filters.

\section{6}

Schaller, K.H., Bundesministerium fuer Umwelt, Naturschute und Reaktorsicherheit, Bonı, Federal Republic of Germany

Radiological Protection Principles for the Decommissioning and Dismantling of Nuclear Power Plant - International Activitics

CONF-8611297; Radiation Protection Principles for Management of Solid Radioactive Waste, Proceedings of a Closed Meeting of the Strahlenschutzkommission, Gundremmingen, Federal Republic of Germany, November 6-7, 1986, Vol. 11, 22.3 pp.; (pp. 2(13-223) (1988)

The International Atomic Energy Agency (IAEA), Nuclear Energy Agency (NEA) of the Organization for Economic Cooperation and Development (OECD), and European Atomic Encrgy Community (EURATOM) are international organizations concerned with and cooperating on problems of waste management and radiological safety in relation to the decommissioning of nuclear installations. International activities currently are concerned with the methodology for evaluating radiological consequences of the management and treatment of very low-level solid waste from decommissioning, criteria for selling up a time schedule for decommissioning, dumping sites for disposal, and the institutions responsible for planning and surveillance of disposal of solid wastes from decommissioning in European Community member states.

\section{7}

Schenker, E., D. Buckley, H.P. Alder, W. Francioni, W. Hecss, and $A$. Conrath

\section{The VS-Decontamination Process}

Water System of Nuclear Rcactor Systems 5; 2 pp. (1989, October 23-27)

The new VS-Process was developed in order to reduce the treatment temperature. The process consists of an oxidizing treatment by a solution containing permanganic acid and chromic acid, followed by a solution containing mainly oxalic acid.

This process developed to decontaminate parts of pressurized water reactors (PWRs) may also be applicd with some modifications to boiling water reactors (BWRs) and other systems. In the past year, this process has been sucesssfully experienced in the decontamination of main coolant pumps of PWRs with a mean decon factor of 10 to 150), and also on the gas cleaning system of a high temperature gas-cooled reactor (THTR $3\left(K^{0}\right)$ ) with a mean decon factor of 30 to $4(K)$. In both cases no deleterious effects on the materials was found. The liquid radioactive waste will be treated for solidification suitable for long term storage.

\section{8}

Schmitt, R.C., H.W. Reno, K.J. Bentley, and D.E. Owens, EG\&G Idaho, Inc., Idaho Falls, ID

TMI-2: Lessons Iearned by the U.S. Department of Encrgy - A Programmatic Perspective

DOE/ID-10276; $108 \mathrm{pp}$. (199), March)

This report is a summary of the lessons learned by the U.S. Department of Encrgy during its decade-long participation in the rescarch and accident cleanup project at Three Mile Island Nuclear Power Station Unit 2. near Harrisburg, Pennsylvania. It is based on a review of a wide range of project documents and interviews with personncl from the many organizations involved. The lessons are organized into major subjects with a bricf background section to orient the reader to that subject. The subjects are divided into subtopics, each with a bricf discussion and a scries of lessons learned. The lessons are very brief and each is preceded with a keyword phrase to highlight its specific topic. References are given so that the details of the subject and the lesson can be further investigated. 
219

Schork, J.S., and B.A. Parfitt, GPU Nuclear Corporation, Middletown, PA

Heat Stress Control in the TMI-2 Defucling and Decontamination Activitics

Transactions of the Amcrican Nuclear Socinty 57:467-469; Nuclear Fission, Procecdings of the 1988 International Conference, Washington, DC, October 30-November 4, 1988 (1988)

During the initial stages of the Three Mile Island Unit 2 (TMI-2) defucling and decontamination activities for the reactor bullding, it was realized that the high levels of loose radioactive contamination would require the use of extensive protective clothing by entry personnel. While there was no doubt that layered protective clothing protects workers from becoming contaminated, it was recognized that these same layers of clothing would impose a very significant heat stress burden. To prevent the potentially serious consequences of a severe reaction to heat stress by workers in the hostile environment of the TMI-2 reactor building, and yet maintain the reasonable work productivity necessary to perform the recovery adequately, an effective program of controlling worker exposure to heat stress had to be developed.

220

Schwartzkopff, K., Bundesministerium fuer Umwelt, Naturschute und Reaktorsicherheit, Bonn, Federal Republic of Germany

Licensing and Surveillance of Activitics for Decommissioning and Dismantling of Nuclear Power Plant, Shown by the Niederaichbach Reactor as an Example

CONF-8611297; Radiation Protection Principles for Management of Solid Radioactive Waste, Proceedings of a Closed Mecting of the Strahlenschutzkommission, Gundremmingen, Federal Republic of Germany, November 6-7, 1986, Vol. 11, 223 pp.; (pp. 73-91) (1968)

The contribution gives an analysis of the term "decommissioning" and explains the stages and relevant work to be done from the legal point of view. The regulatory provisions relating to the participation of the public defines different requirements for the various decommissioning phases. The author discusses and explains some sclected aspects of the licensing procedure and the weighing of interests with regard to the various activitles involved, as well as the experience gained with the Niederaichbach reactor KKN, which was the first plant to be decommissioned in the Federal Republic of Germany.

\section{1}

Science and Technology Agency, Nuclear Safety Burcau, Tokyo, Japan

State of Dismantling Reactor Facilities (JPDR) in Tokai Rescarch Establishment, Japan Atomic Encrgy Rescarch Institute

Genshiryoku Anzen Iinkai Geppo 129:26 (1989, December)

This is a report on the state of dismantling at the Japan Power Demonstration Reactor. In fiscal year 1988 , the work of dismantling in-core structures was carried out, and the machinery and equipment in the fucl storage building were removed. The details of the work methods and processes were presented beforehand. The presence of the personnel of the Nuclear Safety Bureau confirmed that the dismantling work was carried out safely. The dismantling consists of: (1) the removal of the in-core structures in the reactor pressure vessel and in the spent fucl storage pool; (2) the removal of facilities, machinery and equipment in the fuel storage pool in the fucl storage building; (3) the installation of electrolytic decontamination equipment as the preparation for decontamination after removal; and (4) the refitting of the damp condenser building for the volume reduction of radioactive wastes. The radiation exposure of 251 workers who took part in the work was lower than the allowable dose. The wastes were 22 tons of metals and 1.6 tons of concrete.

222

Sciki, Y., and K. Takahashi, Japan Atomic Energy Rescarch Institute, Tokai Research 
Establishment, Department of Japan Power Demonstration Reactor, Tokai, Ibaraki, Japan

\section{Activatei Concrete Cutting Machine (Reactor Decommissioning)}

Robot 67:46-56 (1989, March)

The Japan Power Demonstration Reactor (JPDR) was the first nuclear power gencration plant in Japan. The JPDR decommissioning program was initiated in 1981 by the Japan Atomic Encrgy Rescarch Institute (JAERI) under contract from the Science and Technology Agency (STA). This program consists of the development of techniques not only for reactor dismantlement but also for the dismantlement of the JPDR plant. This paper describes the cutting machine that has been developed in this program. It can remove cut concrete blocks from the biological shicld wall, using a remote control system.

\section{3}

Sheil, A.E., British Nuclear Fucls, Limited, Sellafield, Cumbria, United Kingdom

\section{Decommissioning at Scllaficld}

Proceedings of the 1989 Annual DOE Model Conference, Oak Ridge, TN, October 3-6, 1989, 54 pp.; (p. 17) (1989, Octobcr 3-6)

British Nuclear Fucls Laboratory at its Sellaficld site is responsible for the decommissioning of a wide diversity of plant types utilized in the nuclear industry. On one compact site there are decommissioning requirements spanning the whole cycle from reactors through reprocessing to plutonium and uranium finishing and plutonium fucl manufacture. In addition there are the associated waste handling and storage facillites together with a number of miscellanecus plants. As part of its policy for managing redundant facilities the Decommissioning Unit is undertaking a substantial decommissioning program. The paper will describe some of the lead projects including a mixed oxide production facility, a fucl storage and decanting pond, contaminated pile cooling air discharge and filter chimneys some $420 \mathrm{ft}$ high and the retrieval of solid intermediate level waste from a dry storage silo. In particular the technically challenging aspects of the projects will be amplified such as development of remote handling, techniques to strictly confine alpha contamination during cutting and dismantling and onginecring operations in contaminated pond water. To support this practical decommissioning work a significant development program is required. The paper will outllne the scope of this program and indicate particular areas of interest such as decontamination and waste analysts and waste classification rechniques.

\section{4}

Skupinski, F., Commission of the European Communitics, Brusscls, Belgium

The European Community's Rescarch and Developınent Program on the Decommissioning of Nuclear Installations

Decommissioning of Nuclear Facilitics, Procecdings of an International Scminar, London, United Kingdom, July 6-7, 1988; (19 pp.) $(1988$, July 7)

The Commission of the European Communities (CEC) continues implementing a second rescarch program on the decommissioning of nuclear installations (1984-8), after having completed a first program on the decommissioning of nuclear power plants (1979-83). The program, implemented in about 70 rescarch contracts with organizations of private firms in the member states, includes the development and testing of advanced techniques, such as decontamination and dismantling, and the consideration of the radioactive waste arising therefrom. Work is done at laboratory scale or in the frame of large-scale decommissioning operations. The author glves an overvicw on the technical content and on some selected results.

\section{5}

Societe des Travaux en Milicu Ionisant, Paris, France

\section{EL-3 Dismantling of an Experimental Reactor}

Rayonnements Ionisants 18(1):35-45 (1989, April) 
The EL3 experimental reactor was definitively stopped in March 1979. Its decommissioning has been pronounced in the end of 1982 . This article is concentrated at decontamination and dismantling works necessitated by its passage at the dismantling level 2.

226

Soo, P., J.W. Adams, and C.R. Kempf, U.S. Nuclear Regulatory Commission, Division of Engineering, Washington, DC

The Impact of Light-Water Reactor Decontaminations on Solidification, Waste Disposal, and Associated Occupational Exposure

NUREG-0975 (Vol. 6); Compilation of Contract Research for the Materials Engineering Branch, Division of Enginecring - Annual Report for FY 1987; (pp. 358-374) (1988, Junc)

During light-water reactor operation, components in the primary system become radioactive because of the deposition of corrosion products which are transported from the core regions by the coolant. In order to minimize worker exposure to radiation during routine maintenance operations, industrial procedures have been developed to chemically remove the corrosion products and the activity that they contain. After the corrosion products have been removed by organic reagents, the waste stream is passed through mixed (anion/cation) resin beds which remove residual reagent and the radioactive and nonradioactive lons in solution. The resins are elther sealed in high-integrity containers or they may be solidified in cement, or some other matrix, in order to meet structural stability requirement specified in the U.S. Nuclear Regulatory Commission (NRC) Technical Position on Waste Form (NRC, 1983). The current program is an effort to evaluate the solidification processes that are being used in industry for decontamination waste, and to determinc how the wastes behave during on-site storage and subsequent disposal at a shallow-land burial site. Particularly important are the corrosion of container materials by spent resins, and resin degradation mechanisms which could lead to gas gencration and pressurization of sealed containers. Another important consideration invoives the potential for the cracking of cement-based decontamination waste forms by alternate freeze-thaw cycling. The frecze-thaw cycling effort is close to completion, the container corrosion work will continue for approximately one more year to obtain long-term performance data, and the resin degradation effort is currently being initiated.

\section{7}

Soo, P., C.R. Kempf, K. Brumfield, L.W. Milian, and J.W. Adams, Brookhaven National Laboratory, Upton, NY

The Impact of LWR Decontaminations on Solidification, Waste Disposal and Associated Occupational Exposure

NUREG/CR-3444; BNL-NUREG-51699 (Vol. 6); $80 \mathrm{pp}$. (1989, November)

Studies were carried out to investigate if simulated decontamination reagent/resin waste combinations in light water reactor systems could give rise to thermal excursions during dewatering events. The results of temperature measurements and visual observations are given. In addition the corrosion of various container materials in simulated decontamination resin waste was studies. In particular, the effects of gamma irradiation on the materials were quantified.

\section{8}

Standard Guide for Nuclear Facility Decommissioning Plans

ASTM Standards 1989, Section 12: Nuclear, Solar, and Geothermal Energy, 895 pp.; (pp. 817-821) (1989)

This guide applies to decommissioning plans for any nuclear facility whose operation is governed by U.S. Nuclear Regulatory Commission (NRC) or agreement state license, or under U.S. Department of Energy (DOE) orders. The guide applies to the preparation and content of the decommissioning plan document itself. This standard may involve hazardous materials, operations, and equipment. 
229

Standard Guide for Radioactive Pathway Methodology for Relcase of Sites Following Decommissioning

ASTM Standards 1989, Section 12: Nuclear, Solar, and Geothormal Energy, 895 pp.; (pp. 812-816) (1989)

The purpose of this guide is to provide guidance in determining site-specific conversion factors for translating between dose limits and residual radioactive contamination levels on equipment structures and land areas. This guide serves as an acceptable methodology for translating the yet to be determined dose limits into allowable levels of residual radioactive matcrials that can be left at a site following decommissioning.

\section{0)}

Stang, W., Bundesministerium fuer Umwelt, Naturschutz und Reaktorsicherheit, Bonn, Federal Republic of Germany

\section{Decommissioning of the Gundremmingen Nuclear Power Station, Unit A}

CONF-8611297; Radiation Protection Principles for Management of Solid Radioactive Waste, Proceedings of a Closed Meeting of the Strahlenschutzkommission, Gundremmingen, Federal Republic of Germany, November 6-7, 1986, Vol. 11, 223 pp.; (pp. 37-44) (1988)

The decontamination of the former solid waste store has brought significant experience with regard to building contamination that can be applied to other work as well. There were no problems encountered in the conventional dismantling work so far, and equipment dismantling is expected to be terminated in the early nincties, except for the reactor pressure vessel and the biological shicld. Conventional dismantling of the entire plant is expected to proceed till late in the nineties.

\section{1}

Steele, R., Jr., and J.G. Arendts, Jr., EG\&G Idaho, Inc., Idaho Falls, ID
Seismic Rescarch on an Aged United States Gate Valve and on a Piping System in the Decommissioned Hcissdampfreaktor (HDR): Summary

NUREG/CR-4977 (Vol. 1); EGG-2505 (Vol. 1); 55 pp. (1989, August)

The ldaho National Enginecring Laboratory (INEL) participated in an internationally sponsored scismic rescarch program conducted at a decommissioned experimental reactor facility, the HDR, located in the Federal Republic of Germany (FRG). The research program included the study of the effects of excitation, produced during a simulated scismic event, on 1)the operability and integrity of a naturally aged 8 inch motor-operated gate valve Installed in the Versuchskreislauf (VKL), an existing piping system in the HDR, 2) the dynamic response of the VKL and the operability of snubbers, and 3) the dynamic responses of various piping support systems installed on the VKL. INEL modifted the VKL by installing a mid-life gate valve from a U.S. nuclear power plant and by designing and installing a piping support system typical of U.S. commercial design.

\section{2}

Stcele, R., Jr., and J.G. Arendts, Jr., EG\& $\&$ G Idaho, Inc., Idaho Falls, ID

Scismic Rescarch on an Aged United States Gate Valve and on a Piping System in the Decommissioned Heissdamplicaktor (HDR): Appendices

NUREG/CR-4977 (Vol. 2); EGG-2505 (Vol. 2); $120 \mathrm{pp}$. (1989, August)

This report describes the investigation, results, and conclusions of the INEL effort to determine the cause of the reduced performance of a naturally aged Crane gate valve with a Limitorque motor operator. The motor-operated valve served 25 years in the Shippingport Atomic Power Station as a feedwater isolation valve before being refurbished and installed in a piping system in the Heissdampfreaktor (HDR), where valve operability in typical pressure and temperature environments and during simulated carthquakes was studied. During the test program it 
was disct ed that under some valve hydraulic loadings the motor operator failed to reach torque levels high enough to open the closing torque switch. Failure of the torque switch to open caused the motor to go into a stall. In normal plant service, stalling an operator can cause motor burnout and render the valve inoperable for subsequent safety functions. The investigation concluded that the poor performance of the valve was caused by heating of the motor winc" "s, and by external circuit esistance, both of wh: wented the motor from developing its raised toryu:. The investigation also identified torque spring aging as a problem.

\section{3}

Steiner, H., F.W. Bach, D. Windelberg, and B. Georgi, University of Hannover, Institut Werkstoffkunde, Welfengarten, Hannover, I.tkial Republic of Germany

\section{Acrosol Generation During Cutting of Various Matcrials with Plasma, Laser and Consumable Electrode \\ Journal of Acrosol Science 19(7):1381-1384 (1988)}

There is a large field of application for thermal cutting techniques in the industry. For materials which cannot be cut by conventional oxy-acetylene techniques some other procedures are used. The high concentration of power e.g. laser light or electric arc is the reason of an intensive aerosol generation during thermal cutting. The condensing metal vapor produces particles in a size range that may be dangerous for human beir ; especially in case of cutting high alloyed materials. It is necessary to know the mass and the size distributions of the generated arrosols as a database for installation of filters.

234

Stolz, J.F.

GPU Nuclear Corporation: Availability of Final Supplement 3 to the Programmatic Environmental Impact Statement Relp'ed to Decontamination and Disposal of Wastes írum March 28, $197 \bar{y}$ Áccident Three Milic İsiand Nuclear Station, Unit 2
Federal Register 54(183).39066 (1989, September 22)

The U.S. Nuclear Regulatory Commission has published its Final Report, Supplement 3, to the Programmatic Environmental Impact Statement (PEIS) related to decontamination and disposal of radioactive wastes resulting from the March 28, 1979 accident, Three Mile Island Nuclear Station, Unit 2. Supplement 3 to the PEIS addresses environmental impacts associated with GPU Nuclear Corporation's (GPUN) proposal for long term storage of the facility as well as a number of alternatives.

\section{5}

Surma, J.E., L.K. Holton, Jr., Y.B. Katayama, J.E. Gose, F.E. Haun, and R.D. Dierks, Pacific Northwest Laboratory, Richland, WA

Cleanout and Decontamination of Radiochemical Hot Cells

PNL-SA-17285; CONF-900210; Waste Management '90: Working Towards a Cleaner Environment - Waste Processing, Transportation, Storage and Disposal, Technical Programs and Public Education, Proceedings of a Conference, Tucson, AZ, February 25-March 1, 1990; (25 pp.) (1990, January)

The Pacific Northwest Laboratory (PNL) is developing and employing advanced remote and contact technologies in cleaning out and decontaminating six raciochemical hot cells at Hanford, Washington, under the U.S. Department of Energy's Surplus Facilities Management Program. The program uses a series of remote and contact decontamination technique to reduce costs and to significantly lower radiation doses to workers. Refurbishment of the cover blocks above the air lock trench reduced radiation exposure in the lock and cleanout, and decontamination of an anayytical cell achieved a reduction in radioactive contamination. Nuclear Regulatory Corsn ission-approved Type B burial boxes are also ${ }^{*}$ : used to reduce waste disposal costs and rad jes. PINL is currently decommissioning its $p$ : ... 'radioactive liquid-fed cerdmic melter. Special tools have been developed and are being used $1 .$. accomplist the worid's first such eff ort. 
236

Tachon, M., Commissariat a l'Energie Atomique, Etablissement de la Vallee du Rhone, Bagnols-sur-Ceze, France; Pacific Northwest Laboratory, Richland, WA

Dismantling of an Alpha Contaminated Hot Cell at the Marcoule Filot Plant

CEA-CONF-9889; CONF-8810305; Dismantling of Nuclear Plants, Wastes and Associated Problems of Radiation Protection, Proceeding of an Association pour les Techniques et les Sciences de Radioprotection Meeting, Grenoble, France, October 5-7, 1988; (15 pp.) (1988)

For the remodeling of Marcoule Pilot Plant, Cell 82 (old unit for plutonium solution purification by extraction) was dismantled. About 42 tons of wastes were evacuated. Some wastes were decontaminated by mechanical means while other wastes with higher residual activity were stored for subsequent processing. The operation shows that dismantling of a hot cell is possible even if incorporated in an operating plant.

\section{7}

Takeishi, H., T. Suzuki, S. Iso, N. Kohno, A. Hoshino, C. Yonezawa, M. Hatakeyama, and T. Komori, Japan Atomic Energy Research Institute, Tokai Research Establishment, Department of Japan Power Demonstration Reactor, Tokai, Ibaraki, Japan

Determination of the Long-Lived Nuclides in Biological Shielding Concrete, Ion Exchange Resin and Fuel Storage Pool Water of JPDR

JAERI-M-89-224; 54 pp. (1990, January)

In the planning and implementation of the decommissioning programs of nuclear facilities, field work programs, and treatment/disposal programs of radioactive wastes for the establishment of the reactor decommissioning technology, it is essential to obtain the basic data for estimating the radionuclide inventory of nuclear facilities. To estimate the radionuclide inventory, it is especially necessary to detern ine the Inng-lived nuclides, such as $\mathrm{C}-14, \mathrm{H}-3$, Co-60, Cs-134, Cr-137, Eu-152, Eu-154, and Pu-239, among the radionuclides generated the reactor material during reactor operation. Among these nuclides, gamma-ray emitting nucities can be measured by nondestructive analyses. On the other hanu, alpha- and beta-emitting nuclides must be measured by destructive analyses including individual chemical separation. At the Decommissioning Waste Management Division of JPDR, the destructive analyses for gamma-ray emitting nuclides were carried out for samples taken from the reactor materials of JPDR, but the analyses for alpha- and beta-emitting nuclides were not done because the methods for these nuclides had not yet been developed. Since the measurements of these alphaand beta-emitting nuclides are indispensable for the comprehensive estimation of radionuclide inventory, analytical methods for determining the amounts of these nuclides were developed at the Analytical Chemistry Laboratory. The methods were applied to the analysis of the real amount of the long-lived nuclides in the biological shielding concrete, the ion exchange resin for the purification of the cooling water, and the pool water for the storage of nuclear fucl. The procedures and the results are described in the report.

238

Tarasov, V.M.

JPDR NPP Decornmissioning

Energeticheskoe Stroitel'stvo za Rubezhom 4:\{\$-13 (1989, August)

The process of the Japan Power Demonstration Reactor (JPDR) unit decommissioning is described. The results of investigations carried out to develop a rational program for nuclear power plant dismantling and to determine the efficiency of the methods and hardware used are presented.

\section{9}

Tarcza, J.E., U.S. Nuclear Regulatory Commission, Division of Engincering, Washington, DC

Evaluation of Nuclear Facility Decommissioning Projects (ENFDI) Program 
NUREG-0975 (Vol. 6); Compilation of Contract Research for the Materials Engineering Branch, Division of Engineering - Annual Report for FY 1987; (pp. 347-357) (1988, June)

The objective of this program is to provide data to the U.S. Nuclear Regulatory Commission (NRC) staff which will allow an assessment of man-hours expended, radioactive wastes generated by type and volume, alternative methods of decommissioning, and occupational doses incurred during decommissioning activities. The data provided will also include available cost information to assist the NRC in determining the proper amount of funds which must be available to ensure timely and safe decommissioning of facilities. Additionally, detailed information on waste characterization from reactor decommissioning projects will provide support for regional waste compact guidance. The work effort for FY 1987 was divided into three categories for proper activity definition and cost accounting. Those categories are: program management, collection of data, and analysis and reporting of field data.

\section{0}

The Curious Accountancy of Decommissioning

Power Europe 66:9-10 (1990, February 1)

Financial provision for the decommissioning and waste maragement of the United Kingdom Magnox and Advanced Gas-Cooled Reactor (AGR) is discussed. In the last set of accounts prior to privatization, a decommissioning provision of 8.34 billion Pounds was indicated whereas previous figures had only shown 2.88 billion Pounds. It is suggested that the increase was only achieved on paper, without real financial provision. Estimates of decommissioning costs for the Magncx stations have increased greatly. Cost estimates for AGR decommissioning have still to be released, but it is expected that the post-privatization owners of the nuclear power industry, Nuclear Electric, will have to find 6-7 billion Pounds to dismantle its own reactors. Much of this it hopes to put off for over 100 years. The South of Scotland Electricity Board has made much more realistic provision for its nwn Magnox and two AGR stations. Reprocessing costs for AGR reactor fucl is uncertain, and high reprocessing and decommissioning costs will mean increases in the price of nuclear-generated electricity.

\section{1}

The Lawfulness of a Licence for the Dismantling of a Nuclear Power Plant

Recht der Elektrizitaetswirtschaft 50(12):306-311 (1989, December)

The action was for annulment of a license for the dismantling of the Niederaichbach nuclear power plant $(\mathrm{KKN})$. The action was brought by the local government of Landshut, the argument being that the dismantling work might bring about additional release of radiation affecting the land owned by the town. The local authority had agreed in a previous hearing to the dismantling and removal of the power plant subject to certain conditions and obligations, reserving the right to make further objections which, however, were not filed. The action was judged to be admissible, though without merits, as official dose assessments do not indicate a possible radiation release beyond the maximum permissible limits set by Section $\mathbf{4 5}$ of the Radiation Protection Ordinance. This section requires consideration of all radiation doses possibly emanating from normal operation, and incidents or accidents in a nuclear power plant at home or abroad. The preclusive effect does not extend to facts emerging after end of the period allowed for raising objections. Any new facts emerging after that period need not be introduced in the licensing procedure by way of a motion to restore the original status, but can be asserted by way of raising objections or bringing an action in court. This ruling was given in Regensburg Administrative Court, decision of 13 March 1989, RN 5 K 881274.

\section{2}

Theymann, W., Verein Deutscher Ingenieure (VDI) - Gesellschaft Energietechnik, Duesseldorf, Federal Republic of Germany

Investigations on Selected Components after Decommissioning

CONF-8905318; The AVR Reactor, Proceedings of a VDI Technical Meeting, Aachen, Federal 
Republic of Germany, May 17-19, 1989, Vol. 729, 322 pp.; (pp. 281-284) (1989)

The knowledge and experience gained from erection and operation of the AVR experimental nuclear power station is to be completed after its decommissioning by the examination of components which were subjected to the special conditions of the HTR. Components are to be dismantled for this purpose, which were not intended to be or could not be dismantled during operation. Special removal facilities are necessary for taking out samples or working parts, and there are designs available for these. The post-shutdown investigation program is mainly aimed at the inspection and measurement of removed parts, the measurement of material properties of worked out samples and determining the activity distribution on components and in the circuits. The results will be used for the further development and introduction of the HTR line to the market and also act for the transition of the AVR into a safe enclosure and its later final removal.

243

Thomas, P.J., and T. Boorman, United Kingdom Atomic Energy Authority, Northern Research Laboratories, Seascale, United Kingdom

\section{The Windscale Advanced Gas-Cooled Reactor Stage 3 Decommissioning Project}

Nuclear Technology 86(2):111-119 (1989, August)

The planning and the progress to date of the United Kingdom's first full-scale decommissioning project, which is dismantling the Windscale Advanced Gas-Cooled Reactor to stage 3 (the "greenfield" site concept) are described. The plant and the facilities that are being constructed to dismantle it are described. Methods used to separate and pack for disposal nonradioactive, low-level, and intermediate-level radicactive waste are summarized.

\section{4}

Tundo, D., R.F. Gessner, and R.E. Lawrence, West Valley Nuclear Services Company, Inc., West Valley, NY
Lessons Learned at West Valley During Facility Decontamination for Re-Use (1982 - 1988)

\section{DOE/NE/44139-54; 77 pp. (1988, November)}

The primary mission of the West Valley Demonstration Project (WVDP) is to solidify a large volume of high-level liquid waste $(2.3$ million liters/600,000 gallons) produced during reprocessing plant operations and stored in underground tanks. This is to be accomplished through the maximum use of existing facilities. This required a significant effort to remove existing equipment and to decontaminate areas for installation of liquid and cement processing systems in a safe environment while maintaining exposure to workers as low as reasonably achicvable. The reprocessing plant occupied a building of about $33,000 \mathrm{sq} \mathrm{m}(350,000) \mathrm{sq} \mathrm{ft})$. When the WVDP was initiated, approximately 6 percent of the plant area was in a noncontaminated condition where personnel could function without protective clothing or radiological controls. From 1982 to 1988, an additional 64 percent of the plant was cleaned up and much of this converted to low- and high-level waste processing areas. The high-level liquid and resulting low-level liquids are now being treated in these areas using an Integrated Radwaste Treatment System (IRTS). The Project has now focused attention on installation, qualification and operation of a vitrification system which will convert the remaining high-level waste into borosilicate glass logs. The stabilized waste will be sent to a Federal Repository for long-term storage. From 1982 to 1988, about 70 technical reports were dealing with specitic tasks and cleanup efforts. This report provides an overview of the decontamination and decommissioning work done in that period. The report emphasizes lessons learned during that effort. Significant advances were made in: remote and contact decontamination technology; personnel protection and training; planning and procedures; and radiological controls.

\section{5}

U.S. Department of Commerce, Maritime Administration, Washington, DC

Appendix A to Facility License No. NS-1 Technical Specifications and Bases (Issued as Change No. 10) for the N.S. Savannah Reactor 
Maritime Administration U.S. Department of Commerce, Amendment No. 7

DOCKET 50-238; 230 pp. (1970, November 9)

The Technical Specifications and Port Operation Criteria are incorporated in the license. The licensee shall operate the reactor in accordance with the Technical Specifications. No changes shall be made in the Technical Specifications unless authorized by the Commission as provided in Section 50.59 of 10 CFR Part 50.

\section{6}

U.S. Department of Encrgy, Division of Plans and Evaluation, Washington, DC

\section{Nuclear Reactors Built, Being Built, or Planned - 1989}

DOE/OSTI-8200-R53; 80 pp. (1990, June)

This report contains unclassified information about facilities built, being built or planned in the United States for domestic use or export as of December 31, 1989. The Office of Scientific and Technical Information of the U.S. Department of Energy (DOE) gathers information annually from the headquarters and field offices of DOE, from the Nuclear Regulatory Commission, U.S. reactor manufacturers, U.S. and foreign embassies, and from foreign governmental nuclear departments. The book is divided into three major sections: (1) a reactor locator map and reactor tables; (2) nuclear reactors operating, being built, or planned; and (3) reactors that have been shut down permanently or dismantled. Sections 2 and 3 contain thesc classifications of reactors: Civilian, Production, Military, Export, and Critic Assembly. Export reactors are foreign reactors for which the principal nuclear contractor is an American company. The various classes of reactors within these categories are: Central-Station Electric Power Plant, Dual-Purpose Plant, Experimental Power Reactor, Gencral Irradiation Test Reactor, High-Power Research and Test Reactor, Safety Research and Test Reactor, Research Reactor, and University Research and Teaching Reactor.
247

U.S. Nuclear Regulatory Commission, Division of Low-Level Waste Management and Decommissioning, Washington, DC

Standard Format and Content Guide for Financial Assurance Mechanisms Required for Decommissioning Under 10 CFR parts 30, 40, 70 , and 72 - Revision 1

NUREG-1336 (Rev. 1); 138 pp. (1989, August)

The Standard Format and Content Guide for Financial Assurance Mechanisms Required for Decommissioning under 10 CFR Parts 30, 40, 70, and 72 discusses the information to be provided in a license application a. establishes a uniform format for presenting the information required to meet the decommissioning licensing requirements. The use of the Standard Format and Content Guide will (1) help ensure that the license application contains the information required by the regulations, (2) aid the applicant in ensuring that the information is complete, (3) help persons reading the Standard Format and Content Guide to locate information, and (4) contribute to shortening the time required for the review process. The Standard Format and Content Guide ensures that the information required to perform the review is provided and is in a usable format.

\section{8}

U.S. Nuclear Regulatory Commission, Division of Low-Level Waste Management and Decommissioning, Washington, DC

Standard Review Plan for the Review of Financial Assurance Mechanisms for Dacommissioning Under 10 CFR Parts 30, 40, 70, and 72 - Revision 1

NUREG-1337 (Rev. 1); 44 pp. (1989, August)

A standard review plan (SRP) for the Review of Financial Assurance Mechanisms for Decommissioning under 10 CFR Parts 30, 40, 70 and 72 is prepared for the guidance of Nuclear Regulatory Commission staff reviewers in performing reviews of applications from material licensees affected by the decommissioning regulations 
established June 27, 1988 (53 FR 24018). The principal purpose of the SRP is to ensure the quality and uniformity of staff reviews and to presint a base from which to evaluate the firsenidid assurance aspects of the applications. The 8.7 idontifies who performs the review, the matters that dre reviewed, the basis for the review, how the review is performed, and the conclusions that are sought.

\section{9}

U.S. Nuclear Regulatory Commission, Office of Nuclear Regulatory Research, Washington, DC

Standard Format and Content for Decommissioning Plans for Licensees Under 10 CFR Parts 30, 40, and 70

REG/G-3.65; 13 pp. (1989, August)

This regulatory guide, developed in conjunction with the amendments to the regulations concerning decommissioning, would be applicable to certain licensees when they decide to permanently discontinue all licensed activities involving nuclear materials. The purpose of the guide is to identify the information needed by the U.S. Nuclear Regulatory Commission (NRC) staff for evaluations involving decommissioning. The guide also provides a format for submitting this information. Conformance with this guide is not required, but its use will facilitate preparation of a decommissioning plan by licensees and timely, uniform review by NRC staff. A different format will be acceptahle to the staff if it provides an adequate basis for approval of a decommissioning plan. The guidance is appropriate for use in license amendments to partially clean up a nuclear facility and release that part for unrestricted use at a time other than at the decommissioning of the facility as a whole (e.g., cleanup of separate buildings). The amended sections of the decommissioning rule, 30.36(b), 40.42(b), 70.38(b), require each licensee to notify NRC promptly, in writing, and request termination of license when the licensee decides to terminate all activities involving material authorized under the license.

\section{0}

U.S. Nuclear Regulatory Commission, Washington, DC
Compilation of Contract Rescarch for the Materials Engincering Branch, Division of Engincering - Annual Report for FY 1988

NUREG-0975 (Vol. 7); 363 pp. (1989, May)

This report is part of a compilation of annual reports by contractors to the Materials Engineering Branch of the NRC which concentrate on achicvements in safety research for the primary system of commercial light water power reactors, particularly with regard to reactor vessels, primary system piping, steam generators, nondestructive examination of primary components, and in safety research for decommissioning and decontamination, on-site storage and engineered safety features. This particular report consists of five main sections: (1) Vessel and Piping Fracture Mechanics, (2) Pressure Vessel Surveillance Dosimetry, (3) Steam Generators, Aging and Environmental Cracking, (4) Non-Destructive Examination, and (5) Decommissioning and Fuel Cycle. Under each section is a description of the programs being carried out at individual DOE facilities, the principal NRC contractors.

251

Varley, J.

End to Clcan-up Programme in Sight (TMI-2)

Nuclear Enginecring International34(416):27-31, 33 (1989, March)

The $\$ 1$ billion clean-up program at Three Mile Island Unit 2 has been underway for the last ten years, since the March 28, 1979 accident. The work is expected to be completed towards the end of 1990. This article gives a brief summary of the work completed and plans for completion.

252

Vollradt, J., W. Harbecke, G. Lukacs, and W. Stang, Vereinigte Elcktrizitaetswerke Westfalen AG, Dortmund, Federal Republic of Germany; Kraftwerk Emsland, Lingen, Federal Republic of Germany; Nuklear-Ingenicur Service GmbH, Hanau, Federal Republic of Germany; Kernkraftwerke Gundremmingen 
Betriebsgesellschaft GmbH, Gundremmingen, Federal Republic of Germany

Decommissioning of Nuclear Power Plants Operation Without Generation of Electricity

Kerntechnik 55(2):98-103 (1990, April)

Before any electricity is generated by a nuclear power plant, the feasibility of its decommissioning has to be demonstrated. And for many years after plant shutdown, various regulations have to be complied with until the site has reached such conditions that its use is no longer restricted by radiation protection laws. In the Federal Republic of Germany, for almost 20 years this subject was studied only theoretically. Recently, more and more practical experience has been acquired. This paper deals with the safe enclosure of the boiling-water reactor Lingen, the continuous dismantling of the nuclear power plant Gundremmingen A, the total dismantling of the nuclear power plant Niederaichbach, and briefly mentions experiences at other !lants. Generally, the work up to now has been callicu out according to expectations. But the final repository Konrad is still missing.

\section{3}

Wakui, H., O. Yamamoto, M. Matsui, and M. Kawakami, Chiyoda Chemical Engineering and Construction Company, Limited, Chiyoda, Japan Development of an Advanced Ofr-Gas Scrubber for an Incinerating Melter

CONF-880201; Waste Management '88: Waste Processing, Transportation, Storage and Disposal - Technical Programs and Public Education, Post, R.G. (ed.), Proceedings of a Conference, Tucson, AZ, February 26-March 3, 1988, Vol. 1, 1049 pp.; (pp. 537-542) (1988)

In the Chiyoda R\&D center, the pilot plant of a Multi-Purpose Incinerating Melter has been tested for two years. This system can treat a wide variety of waste, combustibles, and noncombustibles, and convert these into glass-like stable solids. The incincrating melter is a partly rotating rotary-kiln-type furnace where the wastes are burned, molten and vitrified. The off-gas scrubber is a wholly integrated system that uses the jet-bubbling technology developed by Chiyoda. The efficiency of the system is excessively beyond the level of conventional scrubbers.

\section{4}

\section{Waterjet Cutting: Systems Offer Versatility}

Robotics World 7(2):42-43 (1989, March-April)

Robot-controlled waterjet cutting of nonmetallic workpieces offers greater flexibility than press cutting and manual trimming, plus a high degree of precision in three dimensions. Design modifications of existing products, or the production of prototypes, is greatly simplified since no expensive special tooling is required. Waterjet cutting systems have demonstrated effectiveness in cutting a broad number of materials, hard and soft. The technology is dust free. The water stream is as thin as a human hair and carries a power of 20 to $150 \mathrm{hp}$. Its cutting ability can be enhanced by the use of abrasives. Systems from a number of suppliers are described.

255

Watzel, G.V.P., Bundesministerium fuer Umwelt, Naturschutz und Reaktorsicherheit, Bonn, Federal Republic of Germany

Experience Gained with the Decommissioning of Nuclear Power Plant Operated by the Federal German Electric Utilities

CONF-8611297; Radiation Protection Principles for Management of Solid Radioactive Waste, Proceedings of a Closed Meeting of the Strahlenschutzkommission, Gundremmingen, Federal Republic of Germany, November 6-7, 1986, Vol. 11, 223 pp.; (pp. 45-56) (1988)

During current decommissioning work for the installations RWE-Bayernwerk, unit A, Lingen reactor station, and VAK reactor station, basic questions have emerged that are discussed by the author and refer to the following: Licences for handling of radioactive substances, the definition of the term "nuclear installation," participation of the public in licenses for decommissioning, the determination and classification of material as noncontaminated material, the priority of recycling, 
the restrictive release value and its compatibility with internationally applied values, the practical value of proof of release limits, and the minimization of the radiation exposure.

\section{6}

Weick, J.M., and W. Stor', Trumpf GmbH, Ditzingen, Federal Republic of Germany

New Aspects in Cutting Metals with CO2 Lasers

$$
\text { Laser Optoelektron 20(2):48-51 (1988, April) }
$$

The development of cutting of metals using $\mathrm{CO}-2$ lasers is implemented as well by using the pulsed mode as by optimizing the gas flow and improving gas jets. Examples of these new aspects are discussed.

\section{7}

Weiss, A.J. (Comp.), U.S. Nuclear Regulatory Commission, Office of Nuclear Regulatory Research, Washington, DC; Brookhaven National Laboratory, Upton, NY

Decontamination and Decommissioning, License Renewal, Human Factors, Generic Issues, Risk Analysis/PRA Applications, Innovative Concepts for Increased Safety of Advanced Power Reaciors

NUREG/CP.0097 (Vol. 1); $561 \quad$ pp.; CONF-8810155 (Vol. 1); Proceedings of the 16 th Water Reactor Safety Information Mecting, Gaithersburg, MD, October 24-27, 1988, 561 pp. (1989, March)

This five-volume report contains 141 papers out of the 175 that were presented at the Sixteenth Water Reactor Safety Information Meeting held at the National Institute of Standards and Technology, Gaithersburg, Maryland, during the week of October 24-27, 1988. The papers are printed in the order of their presentation in each session and describe progress and results of programs in nuclear safety research conducted in this country and abroad. Foreign participation in the meeting included twenty different papers presented by researchers from Germany, Italy, Japan, Sweden, Switzerland, Taiwan and the United Kingdom. The titles of the papers and the names of the adthors have been updated and may differ from those that appeared in the final program of the meeting. This document, Volume 1, discusses Decontamination and Decommissioning; License Renewal; Human Factors; Generic Issues; Risk Analysis/PRA Applications; and Reactor Safety.

258

Wciss, S.H.

Environmental Assessment and Finding of No Significant Impact Regarding Proposed Order Authorizing Dismantling of the Reactor and Decomposition of Component Parts

Federal Register 54(174):37516-37517 (1989, September 11)

The Nuclear Regulatory Commission is considering issuance of an Order authorizing the University of California, Berkeley (UCB) to dismantle their TRIGA rescarch reactor facility located on the licensee's campus in Berkeley, California and to dispose of the reactor components in accordance with the application dated January 8, 1988, as supplemented on January 31, 1989 and April 14, 1989.

259

West, M.L., R.A. Hunt, and D. Paine, ECOTEK, Inc., Erwin, TN

Decontamination and Decommissioning of a Plutonium Fabrication Facility

Proceedings of the 1989 Annual DOE Model Conference, Oak Ridge, TN, October 3-6, 1989, 54 pp.; (p. 17) (1989, October 3-6)

The presentation describes an active project involving the decontamination and decommissioning of a plutonium fabrication facility at Nuclear Fucl Scrvices, Inc., in Erwin, Tennessee. Approximately 10,500 square feet of currently unused plutonium facilities are located in two separate buildings on the NFS-Erwin site. Waste processing strategy centers around decontamination and sectioning with a high-pressure water jet system incorporating a 
recirculated medium; volume reduction in a high capacity shear baler; and material control and accountability utilizing a state-of-the-art five station active-passive neutron NDA system. A stainless steel container has been constructed to house the sectioning and decontamination station. This container attaches directly to a shear baicr, which has been modified to totally encapsulate all surfaces subject to contamination. The NDA system consists of five stations: (1) pre-decontamination inventory station, (2) decontamination evaluation station, (3) criticality evaluation and monitoring, (4) bale and drum counter, and (5) bulk-MOX evaluation. The majority of waste consists of 136 gloveboxes containing process equipment. Additional sources are ventilation duct-work, piping, conduit, scrabbled concrete and soil.

\section{$26(0)$}

Williams, J., United Kingdom Atomic Energy Authority, Harwell Laboratory, Harwell, United Kingdom

Decommissioning in the United Kingdom Atomic Energy Authority

Decommissioning of Nuclear Facilities, Proceedings of an International Seminar, London, United Kingdom, July 6-7, 1988; (16 pp.) (1988, July 7)

The United Kingdom Atomic Energy Authority (AEA), which has been involved in the development of nuclear power for over 30 years, has constructed and operated a wide range of nuclear facilities, mostly as prototype or demonstration plants. Euch of these facilities needs to be decommissioned after it reaches the end of its working life. The anthor describes the AEA's policy on decommissioning and the research and development activities under way to allow the work to be done safely and efficiently.

\section{1}

Williams, M.S., and P. Waldron, University of Bristol, Bristol, United Kingdom

\section{Demolition of Structural Concrete Containing Unbonded Tendons}

Decommissioning Offshore, Onshore and Nuclear Works, Whyte, I.L. (ed.), Proceedings of the First International Conference, Manchester, United Kingdom, March 22-24, 1988. Thomas Telford Limited, London, United Kingdom, 338 pp.; (pp. 121-130) (1988, March 22-24)

This paper describes an investigation into the movement of unbonded pre-stressing tendons in greased plastic sheaths when cut during the demolition of structures. Results are presented from an extensive laboratory testing program in which unbonded tendons, cast in concrete beams $3 \mathrm{~m}$ and $6 \mathrm{~m}$ in length, were released under load. A series of subsidiary tests to examine individual parameters is also discussed. Tendon displacements were small, and varied lincarly with the load applied at release. The main parameters affecting tendon movement were the damping effect of the greased plastic casing the energy absorption of the cast-in end anchorage.

\section{2}

Wise, B.M., D.J. Veltkamp, B. Davis, N.L. Ricker, and B.R. Kowalski, University of Washington, Center for Process Analytical Chemistry, Seattle, WA

\section{Principal Components Analysis for Monitoring the West Valley Liquid Fed Ceramic Melter}

CONF-880201; Waste Management '88: Waste Processing, Transportation, Storage and Disposal - Technical Programs and Public Education, Post, R.G. (ed.), Proceedings of a Conference, Tucson, AZ, February 26-March 3, 1988, Vol. 2, 1052 pp.; (pp. 811-818)

Operating conditions in the West Valley Liquid Fed Ceramic Melter (LCFM) are monitored extensively. Principal components analysis (PCA) is a mathematical technique that can be used to identify the "normal modes" of a data matrix so that trends in the data can be easily identified. This paper discusses how PCA can be used on operating data from the LCFM to help identify process upsets, off-specification operating conditions, and failing process sensors. PCA has often been applied to pattern recognition and analytical classification problems. This work, however, represents a new 
application, in that PCA has not previously been applied to data from a dynamic system. The result of this work is a technique for monitoring multivariable processes as projections of the process data into lower dimensional spaces which are most descriptive for the process. PCA has been used previously with LFCM data to determine the conditions which trigger glass melt foaming, but this work represents a new application in that PCA has not previously been applied to dynamic data.

263

Woodard, L.D.

\section{A Look at Air-PAC Machines (Plasma Arc Cutting)}

Welding Design and Fabrication 62(5):25-28 (1989, May)

Accustomed to fast, clean plasma-arc cutting by machine, fabricators are catching on to the process for manual cutting, too. Portable air-plasma cutting units that run on standard line power are putting the plasma torch into the cutting operator's hand. These low-amperage machines, rated 15 to 15() A capacity, cut stecl up to 1- to 5-in. thick, leaving edges practically dross-free. These scaled-down versions require no special plasma or shiclding gas. Using clean, dry compressed air, many machines run on $110 / 220-\mathrm{V}$ line power, bringing the advantages of plasma cutting to every shop and even to field use. The author describes these portable plasma-arc cutting devices, types of output, types of hand torishes, and maintenance and repair applications.

\section{4}

Woods, P.B., and P.K. Basu

\section{Regulatory Procedures for the Decummissioning of Nuclcar Installations}

Derommissioning of Nuclear Facilitics, Proceedings of an Interuational Seminar, London, United Kingdom, July 6-7, 1988; (16 pp.)

The questions that the regulators have to address during the decommissioning phase of a nuclear installation are the same as those during the operational phase: (1) What are the potential radiological and conventional risks posed by the operation of the installation, are they within the limits, and has all that is reasonably practicable been done to minimize these risks? (2) What are the environmental impacts of operating the installation, are they within the limits, and have they been minimized?

\section{5}

Young, S.

Long Goodbye - Why it Will Take $1(x)$ Years to Demolish This (Berkeley) Nuclear Power Station

Telegraph Weckender Magazine (United Kingdom) (890218):24-28, 30 (1989, February 18)

The Berkeley nuclear power station in Gloucestershire will be the first commercial power station to be completely demolished in Britain. It will ccase to generate electricity on March 31, 1989 and will he dismantled by the Central Electricity Generating Board over the next 100 or so years. The first stage (about 5 years) will be the removal of the fuel rods to the Sellafield Reprocessing Plant. Over the next 5-7 years, everything except the reactor and immediate containment will be dismantled. Then an intermission of 100 years is proposed to allow the radiation levels to fall before the demolition of the reactor. Opponents of the scheme advocate defuelling and sealing the reactors permanently, They argue that demolition multiplies the amount of waste, the transportation of which increases the risk of accidents.

\section{6}

Zimmerman, G.P., Oak Ridge National Laboratory, Energy Division, Oak Ridge, TN

\section{Conceptual Design for a Land Decontamination} Robot

ORNL/TM-10416; 50 pp. (1989, November)

This study is the conceptual development of a machine to be used in the clcanup and treatment of land arcas contaminated by a nuclear accident: a system of hardware components which could remove 
radioactive, fallout-type contamination from rolling terrain. The concept described in the study is a remotely-operable mobile system constructed of commercially available parts referred to as a land decontamination rohot. Two versions are considered: a truck mounted vacuum loader unit; and a trailer mounted unit pulled by a bulldozer type crawler. The hardware costs of the truck mounted unit are around $\$ 450,000$, the trailer mounted unit about $10 \%$ more. Not included are the costs of integrating the hardware into an operating decontamination system, computer equipment, software, and programiming of the robot arm, which would at least equal the hardware cost.

\section{7}

30 Years of Experience with Arc Plasma Metal Cutting

Metallurgico Electricidad 2(599):91-96 (1988, April)

The experience gained during the last 30 years with the process of arc plasma metal cutting is summarized. The early methods of constricting the arc and their defects are reviewed followed by a discussion of modern developments, including the injection of protective gas, the Dual Flow system introduced in 1965, injection of oxygen, and finally water injection. The paper then deals with precautions in making the cut and with some economic questions. It refers particularly to the PAC500 water injection process of the ESAB Iberica SA company, which can be used for almost all metals in thicknesses from $1 / 8$ to $3 \mathrm{in}$. 
$87 / 88$

FORMERLY UTILIZED SITES REMEDIAL ACTION PROGRAM 
268

Argonne National Laboratory, Argenne, IL

Enginecring Evaluation/Cost Analysis for the Proposed Removal of Contaminated Matcrials from Pad 1 at the Elya Gate Sitc, Oak Ridge, Tennessece

DOE/OR/237()1-37.1; 36 pp. (1990), Junc)

This enginecring evaluation/cost analysis (EE/CA) has been prepared in support of the proposed removal action for clcanup of radioactively contaminated concrete and soll beneath a bullding on privately owned commercial property in Oak Ridge, Tennessec. The property, known as the Elza Gate sitc, became contaminated with uranium-238, radium-226, thorlum-232, thorium-23), and decay products as a result of the Manhattan Engineer District's storing uranium ore and ore processing residucs at the site in the carly 1940). The U.S. Department of Encigy (DOE) has responsibility for cleanup of the property under its Formerly Utilized Sites Remedial Action Program (FUSRAP). The DOE plans to remove the cracked and worn concrete pad and contaminated subsoil beneath the pad, after which the property owner/tenant will provide clean backfill and new concrete. Portions of the pad and suhsoil are contaminated and, if stored or disposed of improperly, may represent a potential threat 10 public health or welfare and the environment. The EE/CA report is the appropriate documentation for the proposed removal action, as identified in guidance from the US Environmental Protection Agency. The objective of the EE/CA report, in addition to identifying the planned removal action, is to document the selection of response activities that will mitigate the potential for release of contaminants from the property into the environment and minimize the related threats to public health or wellare and the environment.

269

Argonne National Lahoratory, Argonnc, IL: Bechel National, Inc., San Francisco, CA

Work Plan for the Remedial Investigation/Feasibility Study - Environmental
Impact Statement for the Maywoxd Sitc, Maywoxd, New Jersey

DOE/OR/20722-193.1 (Draft); 187 pp. (199), July)

This work plan has becn prepared to document the scoping and planning process performed by the U.S, Department of Encrgy (DOE) to support remedial action activities at the Maywood site located in northern New Jersey in the boroughs of Maywood and Lodi and the township of Rochelle Park. Remedial action at the Maywood site is being planned as part of DOE's Formerly Utilized Sites Remedial Action Program. The DOE is responsible for controlling the relcase of all contaminants from the site. Under the Comprehensive Environmental Response, Compensation, and Llability Act (CERCLA), a remedial investigation/feasibility study (Rl/FS) must be prepared to support the decision-making process for evaluating remedial action alternatives. This work plan contains a summary of information currently known about the Maywood site, presents a conceptual site model that identifies potential routes of human exposure to site contaminants, identifies data gaps, and summarizes the process and proposed studies that will be used to fill the data gaps. In addition, DOE activities must be conducted in compliance with the National Environmental Policy Act (NEPA), which requires consideration of the environmental consequences of a proposed action as part of its decision-making process. It is DOE policy to integrate the requirements of the CERCLA and NEPA processes for remedial actions at sites for which it has responsibility. This work plan also describes the approach that will he used to evaluate potential remedial action alternatives and includes a description of the organization, project controls, and lask schedules ihat will be employed to fulfill the requirements of hoth CERCLA and NEPA.

27()

Argonne National Laboratory, Argonne, IL; Bechlel National, Inc., San Francisco, CA

Work Plan for the Remedial Investigation/Fcasibility Study - Environmental 


\section{Assessment for the Colonic Site, Colonic, New York}

DOE/OR/20722-210.1; 159 pp. (1990, Junc)

This work plan has been prepared to document the scoping and planning process performed by the U.S. Department of Encrgy (DOE) to support remedial action activities at the Colonie site. The site is located in eastern New York State in the town of Colonie near the city of Albany. Remedial action at the Colonie site is being planned as part of DOE's Formerly Utilized Sites Remedial Action Program. The DOE is responsible for controlling the release of all radioactive and chemical contaminants from the site. Under the Comprehensive Environmental Response, Compensation, and Liability Act (CERCLA), a remedial investigation/feasibility study (RI/FS) must be prepared to support the decision-making process for evaluating remedial action alternatives. This work plan contains a summary of information known about the site as of January 1988, presents a conceptual site model that identifies poten ial routes of human exposure to site contaminants, i entifies data gaps, and summarizes the process and proposed studies that will be used to fill the data gaps. In addition, DOE activities must be conducted in compliance with the National Environmental Policy Act (NEPA), which requires consideration of the environmental consequences of a proposed action as part of its decision-making process. This work also describes the approach that will be used to evaluate potential remedial action alternatives and includes a description of the organization, project controls, and task schedules that will be emnloyed to fulfill the requirements of both CERCLA and NEPA.

\section{1}

Baublitz, J E.

Certification of the Radiological Condition of Thirty-Five Private Propertics Located in Colonic and Albany, NY

Federal Register 54(150):32.731-327.32 (1989, August 7)

The U.S. Department of Energy (DOE) has completed radiological surveys and taken remedial action to decontaminate 35 properties in Colonic and Albany, New York. The propertles were found to contain quantities of radioactive material from uranlum processing activities conducted at the former National Lead (NL) Industries Plant, DOE has also implemented a remedial action project in the Albany and Colonic, New York, areas as part of a specially authorized research and development project, The Energy and Water Appropriations Act for FY 1984. This program's objective is to ensure that any properties contaminated as a result of activities at the former NL Industries can be certified to be within applicable decontamination criteria and standards established for the project and consistent with current radiological guidelines for protection of the general public.

\section{2}

Cotten, P.R., Oak Ridge Associated Universities, Energy/Environment Systems Division, Oak Ridge, TN

\section{Verification of 1988 Remedial Actions, Vicinity Propertics, Colonic Interim Storage Site, Colonic, New York}

$$
\text { ORAU-89/H-120; } 39 \text { pp. (1989, Augi ) }
$$

During October 1988, the Environmental Survey and Site Assessment Program of ORAU conducted verification activities on remediated vicinity properties near the Colonie Interim Storage Site in Colonie, NY. The verification included document roviews and independent radiological measurements and sampling. Results of these activities indicated that remedial actions had been effective in reducing the contamination levels to within established guideline levels.

\section{3}

Cotten, P.R., Oak Ridge Associated Universitics, Encrgy/Environment Systems Division, Oak Ridge, TN

Verification Surveys of Non-Designated Vicinity Propertics, Colonic Interim Storage Site, Colonic, NY 
ORAU-89/H-91; 37 pp. (1989, August)

During September, 1988, the Environmental Survey and Site Assessment Program of the Oak Ridge Associated Universities (ORAU) conducted verification activities on eight nondesignated vicinity properties near the Colonie Interim Storage Site in Colonie, New York. These properties were selected by DOE from approximately 160 properties in the immediate vicinity of the site which had been previously surveyed and determined not to require remediation. The selected properties were those which had contained the highest below-guideline levels of uranium. They were selected for resurvey because small variations in measurcment and sampling results, possibly caused by a variety of procedural and site-specific factors, could have resulted in the levels exceeding the established guidelines. The purpose of the independent review was to verify that the designation process adequately identified the contamination sites, and that there was no potential risk for members of the general public to be exposed to levels of radiation that could cause them to receive doses of radiation even approaching the 100 mrem per year limit. Based on the survey findings, it is ORAU's opinion that the presence of two small areas found to have U-238 concentrations exceeding the authorized limits for the project does not indicate a deficiency in the ORNL surveys, and that the ORNL reports should be considered as adequately and accurately represciting the status of the properties at the time the surveys were conducted.

274

Cottrell, W.D., R.D. Foley, and C.A. Johnson, Oak Ridge National Laboratory, Oak Ridge, TN

Results of the Indoor Radiological Survey at the W.R. Grace Company, Curtis Bay Site, Baltimore, Maryland

C?NL/TM-10439; 33 pp. (1989, July)

The W.R. Grace Cumpany, Davison Chemical Division, conducted developmental research and extraction of thorium from monazite ore at its Curtis Bay fac:'ity in Baltimore, Maryland, during the 1950s under contract to the Atomic Energy Commissiois (AEC). Only one of the numerous buildings on the site was used for these operations. A 1979 aerial survey of the site for the Department of Energy (DOE) indicated that a comprehensive ground survey was required to determine whether or not any contamination renained from the AEC activities in that building. A radiological scoping survey performed later that year for DOE by a team from the Measurement Applications and Development Group of the Health and Safety Research Division, Oak Ridge National Laboratory (ORNL), disclosed surface contamination (alpha) levels in excess of DOE criteria on all five levels of the building. As a result of this finding, two additional surveys were performed in 1986 by ORNL at the request of DOE to evaluate any present or potential health risk. They are detailed in this report. The results of the 1986 surveys revealed several areas having elevated levels of radiation as a result of significant quantities of thorium on some building surfaces such as floors and ceiling beams. Most areas were small spots and in locations of low occupancy; thus, the poss:" 'lity for significant exposure to workers was judged to be low. To confirm this evaluation, annual radiation exposure estimates for workers frequenting the few, larger contaminated areas on the site were derived using ORNL survey data and occupancy factors provided by the W.R. Grace Company. Estimates ranged from 27 to $41 \mathrm{mrem} / \mathrm{yr}$ or a maximum of $41 \%$ of the basic dose limit of $100 \mathrm{mrem} / \mathrm{yr}$ for members of the general public.

\section{5}

Devgun, J.S., and N.J. Beskid, Argonne National Laboratory, Argonne, IL

The Environmental Compliance Process at New York FUSRAP (Formerly Utilized Sites Remedial Action Program) Sites

CONF-9004181; Proceedings of the U.S. Departrent of Energy Remedial Action Program Mecting, Albuquerque, NM, April 16-19, 1990; (16 pp.) (1990)

Five sites in New York are undergoing remedial action planning under the Department of Energy's (DOE) Formerly Utilized Sites Remedial Action Program (FUSRAP). The Colonic site is located in the town of Colonie, about 4 miles northwest of 
downtown Albany. The other four sites (Ashland 1, Ashland 2, Seaway, and Linde) are located in the town of Tonawanda, just north of Buffalo, and are collectively known as the Tonawanda site. None of the New York FUSRAP sites are on the National Priorities List (NPL). The Tonawanda sites were included in FUSRAP between 1980 and 1984 because the radioactive material at these sites originated from activities performed for the Manhattan Engineer District (MED) in the 1940s. The Colonie site was assigned to DOE by the U.S. Congress as part of a decontamination research and development project under the 1984 Energy and Water Appropriations Act. DOE is proposing to conduct remedial action planning and remedial action activities at these sites following an integrated approach to comply with the requirements of both the Comprehensive Environmental Response, Compensation, and Liability Act (CERCLA) and the National Environmental Policy Act (NEPA).

276

Devgun, J.S., N.J. Beskid, R.C. Robertson, and R.G. Atkın, Argonne National Laboratory, Argonne, IL

Implementation of an Integrated CERCLA-NEPA Environmental Process at a FUSRAP Site

CONF-890207; Waste Management '89, Proceedings of the 15th International Waste Conference, Tucson, AZ, February 26-March 2, 1989; (11 pp.) (1989)

The Comprehensive Environmental Response, Compensation, and Liability Act (CERCLA) of 1980 and its amendment in 1986 through the Superfund Amendments and Reauthorization Act (SARA) have significantly affected the environmental compliance process. Remedial actions a contaminated sites now must satisfy the requirements of not only the National Environmental Policy Act (NEPA) but also CERCLA, as amended. For planning and conducting remedial actions under the Formerly Utilized Sites Remedial Action Program (FUSRAP), the U.S. Department of Energy has developed and implemented an integrated process aimed at satisfying the requirements of both NEPA and
CERCLA, as amended. The integrated approach involves a single, comprehensive environmental process that resvits in a single set of documentation. The process is stieamlined, efficient, and cost effective and it rinimizes confusion to the public. This paper discusses the need for, and the elements of, the integrated process as applied to FUSRAP sites. The implementation of the process is illustrated through a case study of FUSRAP sites in Tonawanda, New York.

\section{7}

Foley, R.D., and J.W. Crutcher, Oak Ridge National Laboratory, Health and Safety Research Division, Oak Ridge, TN

Results of the Preliminary Radiological Survey at the Former Diamond Magnesium Company Site, Luckcy, Ohio (DMLO01)

ORNL/TM-11182; 32 pp. (1990, February)

As part of the Formerly Utilized Sites Remedial Action Program (FUSRAP), the U.S. Department of Energy (DOE) is implementing a radiological survey program to determine the radiological survey program to determine the radiological conditions at sites that were used by the department's predecessur agencies. One such site is the former Diamond Magnesium Company Facility in Luckey, Ohio. The preliminary radiological survey discussed in this report was conducted at the request of DOE by members of the Measure Applications and Development group of Oak Ridge National Laboratory in December, 1988. The site was used as a magnesium reduction plant during World War II. It was closed in 1945 and reopened in 1949 as a beryllium production facility, operated by Brush Wellman for the U.S. Atomic Energy Commission. The preliminary radiological survey included (1) a surface gamma scan of part of the property outdoors, (2) collection of surface and subsurface soil samples, and (3) collection of water samples. Laboratory analysis of s $\wedge$ il samples showed concentrations of radium-226 in excess of DOE guidelines. A follow-up detailed study is recommended. 
278

Folcy, R.D., and L.M. Floyd, Oak Ridge National Laboratory, Oak Ridge, TN

Results of the Radiological Survey at 90 C Avenue, Lodi, New Jersey (LJ079)

ORNL/RASA-88/67; 11 pp. (1989, June)

Maywood Chemical Works (MCW) of Maywood, New Jersey, generated process wastes and residues associated with the production and refining of thorium and thorium compounds from monazite ores from 1916 to 1956. MCW supplied rare earth metals and thorium compounds to the Atomic Energy Commission and various other government agencies from the late 1940 s to the mid-1950s. Area residents used the sandlike waste from this thorium extraction process mixed with tea and cocoa leaves as mulch in their yards. Some of these contaminated wastes were also eroded from the site into Lodi Brook. At the request of the U.S. Department of Energy (DOE), a group from Oak Ridge National Laboratory conducted an investigative radiological survey during 1988 at 90 C Avenue, Lodi, New Jersey (LJ079), one of the properties in the vicinity of the MCW site. The survey included a gamma radiation scan of the surface and at one meter above the surface, as well as radionuclide sampling of surface and subsurface soil. The survey objective was tu determine whether this site was contaminated with radioactive residues derived from MCW, principally Th-232. Results of the survey demonstrated radionuclide concentrations in excess of DOE remedial action criteria, primarily from the Th-232 decay chain, with some contamination from $\mathrm{Ra}-226$. The radionuclide distributions are typical of the type of material originating from the MCW site.

\section{9}

Foley, R.D., and L.M. Floyd, Oak Ridge National Laboratory, Oak Ridge, TN

Results of the Radiological Survey at 113 Avenue E, Lodi, New Jersey (LJ081)

ORNL/RASA-88/69; 15 pp. (1989, June)

Maywood Chemical Works (MCW) of Maywood, New Jersey, generated process wastes and residues associated with the production and refining of thorium and thorium compounds from monazite ores from 1916 to 1956. IMCW supplied rare earth metals and thorium compounds to the Atomic Energy Commission and various other government agencies from the late 1940s to the mid-1950s. Area residents used the sandlike waste from this thorium extraction process mixed with tea and cocoa leaves as mulch in their yards. Some of these contaminated wastes were also eroded from the site into Lodi Brook. At the request of the U.S. Department of Energy (DOE), a group from Oak Ridge National Laboratory conducts investigative radiological surveys of properties in the vicinity of $\mathrm{MCW}$ to determine whether a property is contaminated with radioactive residues, principally Th-232, derived from the MCW site. The survey typically includes direct measurement of gamma radiation levels and soil sampling for radionuclide analyses. The survey of this site, 113 Avenue E, Lodi, New Jersey (LJ081), was conducted during 1988. Results of the survey demonstrated radionuclide concentrations in excess of the DOE Formerly Utilized Sites Remedial Action Program criteria. The radionuclide distributions are typical of the type of material originating from the MCW site.

280

Foley, R.D., and L.M. Floyd, Oak Ridge National Laboratory, Oak Ridge, TN

\section{Results of the Radiological Survey at 79 Avenue B, Lodi, New Jersey (IJ091)}

\section{ORNL/RASA-88/79; 15 pp. (1989, June)}

Maywood Chemical Works (MCW) of Maywood, New Jersey, generated process wastes and residues associated with the production and refining of thorium and thorium compounds from monazite ores from 1916 to 1956. MCW supplied rare earth metals and thorium compounds to the Atomic Energy Commission and various other government agencies from the late 194(k to the mid-1950s. Area residents used the sandlike waste from this thorium extraction process mixed with tea and cocoa leaves as mulch in their yards. Some of these contaminated wastes were also croded from the site into Lodi Brook. At the request of the U.S. Department of Energy (DOE), a group from Oak Ridge National Laboratory conducts 
investigative rarinlogical surveys of properties in the vicinity of $\mathrm{MCW}$ to cetermine whether a property is contaninated with radioactive residues, principally Th-232, derived from the MCW site. The survey typically includes direct measurement of gamma radiation levels and soil sampling for radionuclide analyses. The survey of this site, 108 Avenue E, Lodi, New Jersey (LJ084), was conducted during 1988. Results of the survey demonstrated radionuclide concentrations in excess of the DOE Formerly Utilized Sites Remedial Action Program criteria. The radionuclide distributions are typical of the type of material originating from the MCW site.

\section{1}

Foley, R.D., L.M. Floyd, R.F. Carrier, and J.W. Crutcher, Oak Ridge National Laboratory, Oak Ridge, TN

\section{Results of the Radiological Survey at 160 Essex Street, Lodi, New Jersey (LJ072)}

ORNL/RASA-88/49; 17 pp.

Maywood Chemical Works (MCW) of Maywood, New Jersey, generated process wastes and residues associated with the production and refining of thorium and thorium compounds from monazite ores from 1916 to 1956. MCW supplied rare earth metals and thorium compounds to the Atomic Energy Commission and various other government agencies from the late 1940s to the mid-1950s. Area residents used the sandlike waste from this thorium extraction process mixed with tea and cocoa leaves as mulch in their yards. Some of these contaminated wastes were also eroded from the site into Lodi Brook. At the request of the U.S. Department of Energy (DOE), a group from Oak Ridge National Laboratory conducts investigative radiological surveys of properties in the vicinity of MCW to determine whether a property is contaminated with radioactive residues, principally Th-232, derived from the MCW site. The survey typically includes direct measurement of gamma radiation levels and soil sampling for radionuclide analyses. The survey of this site, 160 Essex Street, Lodi, New Jersey (LJ072), was conducted during 1987. Results of the survey demonstrated radionuclide concentrations in excess of the DOE Formerly Utilized Sites Remedial Action Program criteria. The radionuclide distributions are typical of the type of material originating from the $\mathrm{MCW}$ site.

\section{2}

Foley, R.D., L.M. Floyd, R.F. Carrier, and J.W. Crutcher, Oak Ridge National Laboratory, Oak Ridge, TN

\section{Results of the Radiological Survey at 174 Essex Street, Lodi, New Jersey (LJ073)}

ORNL/RASA-88/50; 11 pp. (1989, June)

Maywood Chernical Works (MCW) of Maywood, New Jersey, generated process wastes and residues associated with the production and refining of thoriun and thorium compounds from monazite ores from 1916 to 1956 . MCW supplied rare earth metals and thorium compounds to the Atomic Energy Commission and various other government agencies from the late 1940 s to the mid-1950s. Area residents used the sandlike waste from this thorium extraction process mixed with tea and cocoa leaves as mulch in their yards. Some of these contaminated wastes were also eroded from the site into Lodi Brook. At the request of the U.S. Department of Energy (DOE), a group from Oak Ridge $\mathrm{Na}$ 'ional Laboratory conducts investigative radiological surveys of properties in the vicinity of $\mathrm{MCW}$ to determine whether a property is contaminated with radioactive residues, principally Th-232, derived from the MCW site. The survey typically includes direct measurement of gamma radiation levels and soil sampling for radionuclide analyses. The survey of this site, 174 Essex Street, Lodi, New Jersey (LJ073), was conducted during 1987. Results of the survey demonstrated radionuclide concentrations in excess of the DOE Formerly Utilized Sites Remedial Action Program criteria. The radionuclide distributions are typical of the type of material originating from the MCW site.

\section{3}

Foley, R.D., L.M. Floyd, R.F. Carrier, and J.W. Crutcher, Oak Ridge National Laboratory, Oak Ridge, TN

Results of the Radiological Survey at 6 Hancock Street, Lodi, New Jersey (LJ033) 
ORNL/RASA-88/53; 28 pp. (1989, Junc)

Maywood Chemical Works (MCW) of Maywood, New Jersey, generated process wastes and residues associated with the production and refining of thorium and thorium compounds from monazite ores from 1916 to 1956. MCW supplied rare earth, earth metals and thorium compounds to the Atomic Energy Commission and various other government agencies from the late 1940s to the mid-1950s. Area residents used the sandlike waste from this thorium extraction process mixed with tea and cocoa leaves as mulch in their yards. Some of these contaminated wastes were also eroded from the site into Lodi Brook. At the request of the U.S. Department of Energy (DOE), a group from Oak Ridge National Laboratory conducts investigative radiological surveys of properties in the vicinity of MCW to determine whether a property is contaminated with radioactive residues, principally $\mathrm{Th}-232$, derived from the $\mathrm{MCW}$ site. The survey typically includes direct measurement of gamma radiation levels and soil sampling for radionuclide analyses. The survey of this site, 6 Hancock Street, Lodi, New Jersey (LJ033), was conducted during 1985 and 1986. Results of the survey demonstrated radionuclide concentrations in excess of the DOE Formerly Utilized Remedial Action Program criteria. The radionuclide distributions are typical of the type of material originating from the $\mathrm{MCW}$ site.

\section{4}

Gerety, M., J. Nyhan, and R. Oliver, Los Alamos National Laboratory, Los Alamos, NM

History and Geophysical Description of Hazardous Waste Disposal Arca A Technical Arca 21

$$
\text { LA-11591-MS; 90 pp. (1989, October) }
$$

Los Alamos National Laboratory has been disposing of a varicty of radioactive and hazardous wastes in pits and trenches around Los Alamos since 1944. The Area A sice history and enginecring drawings presented in this report, along with the geophysical results, demonstrate that much of the historical information merely indicates what was originally planned for the site and does not represent the final distribution of neaterial. This report demonstrates that geophysical remote sensing can determine pit and trench geometry, accurately locate material, and determine the physical propertie: of sites and buried material. The geophysical techniques illustrated in this report are magnetics, electromagnetics, resistivity, radar, and self-potential. Each of the techniques has its own merit; combining the techniques is the only way to obtain an accurate image of the site and its properties. At Area A, geophysical measurements were definitive in locating and characterizing all known targets as well as liscovering several undocumented ones. With these data, we can safely perform necessary remedial activities such as monitoring, drilling, and relocating material without the fear of breaching an unknown or misplaced storage facility. Furthermore, these data are obtained remotely and without disrupting the ground surface.

\section{5}

Gilbert, T.L., C. Yu, Y.C. Yuan, A.J. Zielen, M.J. Jusko, and A. Wallo, Argonne National Laboratory, Argonne, IL

\section{A Manual for Implementing Residual Radioactive Matcrial Guidelines}

ANL/ES-160; 203 pp. (1989, June)

This manual presents information for implementing U.S. Department of Energy (DOE) guidelines for residual radioactive material at sites identified by the Formerly Utilized Sites Remedial Action Program (FUSRAP) and the Surplus Facilities Management Program (SFMP). It describes the analysis and models used to derive site-specific guidelines for allowable residual concentrations of radionuclides in soil and the design and use of the RESRAD computer code for calculating guideline values. It also describes procedures for implementing DOE policy for reducing residual radioactivity to levels that are as low as reasonably achievable.

\section{6}

Golchert, N.W., Argonne National Laboratory, Argonne, IL 
Surveillance of Site A and Plot $M$ in the Palos Park Forest Preserve - 1989

ANL-90/7; 46 pp. (1990, April)

The results of the environmental monitoring program conducted at Site $\mathrm{A} / \mathrm{Plot} \mathrm{M}$ in the Palos Park Forest Preserve area for CY 1989 are presented. The monitoring program is the ongoing remedial action that resulted from the 1976-1978 radiological characterization of the site. That study had determined that very low levels of hydrogen-3 (as tritiated water) migrated from the burial ground and was present in two nearby hand-pumped picnic wells. The current program consists of sample collection and analysis of air, surface and subsurface water, and bottom sediment. The results of the analyses are used to: (1) determine the migration pathway of water from the burial ground (Plot $M$ ) to the hand-pumped picnic wells, (2) establish if buried radionuclides other than hydrogen-3 have migrated, and (3) generally characterize the radiological environment of the area. Hydrogen-3 in the Red Gate Woods picnic wells was still detected, but the magnitude of the maximum concentration was significantly less than in earlier years. A replacement well was installed in July 1988 in the Red Gate Woods area to provide a source of water for public use that is free of tritium and trace metals. Tritiated water continues to be detected in a number of wells, borcholes, dolomite holes, and a surface stream. For many years it was the only radionuclide found to have migrated in measurable quantities. Recent analyses indicated the presence of strontium-90) in water from a number of boreholes next to Plot $\mathrm{M}$. The available data do not allow a firm conclusion as to whether the presence of this nuclide represents recent migration or rather movement that may have occurred before Plot $M$ was capped. The results of the monitoring program continue to indicate that the radioactivity remaining at Site $\mathrm{A} / \mathrm{Plot} M$ does not endanger the health or safety of the public visiting the site or those living in the vicinity.

\section{7}

Landis, M.R., Oak Ridge Associated Universities, Manpower Education, Research, and Training Division, Oak Ridge, TN
Verification of Remedial Action on Ventilation Systems, Jones Chemical Laboratory, University of Chicago, Chicago, Illinois

ORAU-89/A-42 (1989, January)

Between 1942 and 1953, facilities at the University of Chicago were used by the Manhattan Enginecring District and the AEC for development of separation and verification techniques involving uranium and plutonium. A search of records during the 1970's indicated that the documentation of decontamination efforts conducted after 1952, when the Chicago operations were moved to Argonne National Laboratories (ANL), was inadequate. ANL performed additional radiological evaluations of the facilities in 1976 and 1977, which identified limited areas of the facilitics as having residual contamination in excess of mid-1970's guidelines. ANL performed further remedial actions, completed in 1984, reducing ail areas of residual contamination to guideline levels, except within the exhaust ventilation ductwork in Jones Chemical Laboratory. Beginning in 1987, Bechtel National, Inc. conducted characterization surveys and performed remedial action where necessary in the laboratory to assure that residual contamination in the ductwork satisfied present radiological protection criteria. ORAU's Radiological Site Assessment Program was designated by DOE to perform an independent verification of the effectiveness of these remedial actions. During the period of September 22, 1987 to October 9, 1987, ORAU activities included document reviews, independent direct measurements, and sample analyses. Based on the results and findings of these activities, it is ORAU's opinion that the remedial actions on the ventilation systems at the laboratory have been effective in satisfying established DOE guidelines.

\section{8}

McNamee, E.M., Bechtel National, Inc., Oak Ridge, TN

Reducing Characterization Costs by 30 Percent Through the Use of an Innovative Drilling Strategy

Report; 10 pp. (1989) 
Balancing the cost of thorough sitc characterization against the uncertainties encourrtered during remedial action has always been a primary goal of the U.S. Department of Energy's Formerly Utilized Sites Remedial Action Program (FUSRAP). This goal has been achieved through the development of an iferative sampling for the characterization of radioactively contaminated sites covering large areas. The process utilizes historical information to make preliminary predictions of the horizontal boundaries of contamination. Once the preliminary boundary has been established, a systematic sampling program is conducted around the boundary. If the boundary sampling program fails to establish the horizontal boundaries of the waste, the systematic boundary search is extended in an interative manner. After the boundaries have been established, sampling intervals within the boundaries are reduced and additional samples are collected to determine the depth of the contamination and the consistency of the waste. Biased samples may also be taken to examine any unique features or anomalies identified at any point during the characterization. This itcrative sampling process was implemented at the Ashland 2 FUSRAP site in Tonawanda, Now York, resulting in a cost savings of 30 percent of the total cost of the radiological characterization. This cost savings is based on a comparison between the standard systematic sampling approach typically used on FUSRAP, and the itcrative sampling approach.

\section{9}

Nocy, K.C., and C.M. Sekula, Bechtel National, Inc., Oak Ridge, TN

Radiological Charactcrization Report for FUSRAP Propertics in the St. Louis, Missouri, Arca - Volume I

DOE/OR/20722-203 (Vol. I); 308 pp. (1990, March)

Radiological surveys to support a RI/FS were conducted on properties in Hazelwood, Berkelcy, and St. Louis, Missouri, as part of Formerly Used Sites Remedial Action Program. All these St. Louis area sites are included on the National Priorities List (Superfund). The propertics contain wastes generated by a St. Louis plant between 1942 and the late 195()'s, under contracts with AEC and its predecessor, the Manhattan Engineer District. The goal was (1) identify radionuclides above guideline concentrations present on the properties and to determine depths and areal limits of the contamination. Bechtel National, Inc. conducted the surveys from 1986 through 1939. The results are presented in this report. Survey results indicate that radioactive contamination exceeding current $\mathrm{DOE}$ guidelines is present on some of the properties. The principal contaminant is thorium-230, with some elevaled levels of uranium-238 and radium-226. Given the current use of the properties, there are no immediate health risks to people in the vicinity. There are some properties identified here for which the precise boundaries of contamination have not yet been determined; additional soil samples will be required, and data from them provided in an addendum. Volume I of the Radiological Characterization Report includes: (1.0) survey objectives; the location, description, and history of the sites; and previous radiological surveys; (2.0) survey grid system, methods, sample collection and analysis, characterization results, and background measurements; and (3.0 - 7.0) characterization results for each of the properties surveyed. Volume II and Volume III are the complete data tables for downhole gamma logging, radionuclide and thorium-230 concentrations in soil, and gamma radiation exposure rates for each site.

\section{0}

Nocy, K.C., and C.M. Sckula, Bechtel National, Inc., Oak Ridge, TN

Radiological Charactcrization Report for FUSRAP Propertics in the St. Louis, Missouri, Arca - Volume II: Data Tables

DOE/OR/20722-203 (Vol. II); 243 pp. (1990, March)

Radiological surveys to support a RI/FS were conducted on propertics in Hazelwood, Berkeley, and St. Louis, Missouri, as part of Formerly Used Sites Remedial Action Program. All these St. Louis area sites are included on the National Priorities List (Superfund). The properties contain wastes generated by a St. Lo'ilis plant between 1942 and the 
late 1950's, under contracts with $\mathrm{AEC}$ and its predecessor, the Manhattan Engineer District. The goal was to identify radionuclides above guideline concentrations present on the properties and to determine depths and areal limits of the contamination. Bechtel National, Inc. conducted the surveys from 1986 through 1989. The results are presented in this report. Survey results indicate that radioactive contamination exceeding current DOE guidelines is present on some of the properties. The principal contaminant is thorium-230, with some elevated levels of uranium-238 and radium-226. Given the current use of the properties, there are no immediate health risks tc people in the vicinity. There are some properties identified here for which the precise boundaries of contamination have not yet been determined; additional soil samples will be required, and data from them provided in an addendum. Volume I of the Radiological Characterization Report includes: (1.0) survey objectives; the location, description, and history of the sites; and previous radiological surveys; (2.0) survey grid system, methods, sample collection and analysis, characterization results, and background measurements; and $(3.0-7.0)$ characterization results for each of the properties surveyed. Volume II and Volume III are the complete data tables for downhole gamma logging, radionuclide and thorium-230 concentrations in soil, and gamma radiation exposure rates for each site.

\section{1}

Noey, K.C., and C.M. Sekula, Bechtel National, Inc., Oak Ridge, TN

Radiological Characterization Report for FUSRAP Propertics in the St. Louis, Missouri, Area - Volume III: Data 'Tables (continued)

DOE/OR/20722-203 (Vol. III); 295 pp. (1990, March)

Radiological surveys to support a RI/FS were conducted on properties in Hazelwood, Berkeley, and St. Louis, Missouri, as part of Formerly Used Sites Remediai Action Program. All these St. Louis area sites are included on the National Priorities List (Superfund). The properties contain wastes generated by a St. Louis plant between 1942 and the late 1950's, undef contracts with AEC and its predecessor, the Nanhattan Engineer District. The goal was to identlfy radionuclides above guideline concentrations present on the properties and to determine depths and areal limits of the contamination. Bechtel National, Inc. conducted the surveys from 1986 through 1989. The results are presented in this report. Survey results indicate that radioactive contamination exceeding current DOE guidelines is present on some of the properties. The principal contaninant is thorium-230, with some elevated levels of uranium-238 and radium-226. Given the current use of the properties, there are no immediate health risks to people in the vicinity. There are some properties identified here for which the precise boundaries of contamination have not yet been determined; additional soil samples will be required, and data from them provided in an addendum. Volume I of the Radiological Characterization Report includes: (1.0) survey objectives; the location, description, and history of the sites; and previous radiological surveys; (2.0) survey grid system, methods, sample collection and analysis, characterization results, and background measurements; and $(3.0-7.0)$ characterization results for each of the properties surveyed. Volume II and Volume III are the complete data tables for downhole gamma logging, radionuclide and thorium-230 concentrations in soil, and gamma radiation exposure rates for each site.

292

Vinikour, W.S., and S.C.J. Yin, Argonne National Laboratory, Argonne, IL

Determination of Ecologically Vital Groundwaters at Selected Sites in the Formerly Utilized Sites Remedial Action Program

ANL/EES-TM-377; 48 pp. (1989, August)

The U.S. Department of Energy is classifying groundwaters at sites in its Formerly Utilized Sites Remedial Action Program (FUSRAP'). Of particular concern is the potential presence of groundwaters that are highly vulnerable to contamination and that are either (1) irreplaceable sources of drinking water or (2) ecologically vital. Conditions at nine FUSRAP sites were evaluated to determine if 
Seaway Industrial Park, Colonie Interim Storage Site, and Niagara Falls Storage Site in New York; and the St. Louis Airport Sitc and Hazelwood Intcrim Storage Sitc in Missouri. The analyses indicated that groundwaters are vulncrable to contamination at all but two of the sites - the Ashland 2 and Seaway Industrial Park sites in New York. Groundwater discharge points were identified within a 2-mile radius (i.c., the classification review area) of all of the sites. No ecologically vital groundwater areas exist in the vicinities of any of the nine FUSRAP sites cvaluated.

\section{3}

Williams, M.J., and M.E. Redmon, Bechtel National, Inc., Oak Ridge, TN

\section{Conversion of Mixed Waste to LSA Waste: A} Case Study

Proceedings of the 1989 Annual DOE Model Conference, Oak Ridge, TN, October 3-6, 1989. 54 pp.; (p. 16) (1989, October 3-6)

This paper describes a treatment process that was successfully employed at the National Guard Armory in Chicago, Illinois, to convert sludge classificd as hazardous chemical/radioactive mixed waste to low specific activity (LSA) radioactive waste. The sludge, which was generated during remedial action conducted by the U.S. Department of Energy under the Formerly Utilized Sites Remedial Action Program, was classificd as mixed waste because it contained uranium in concentrations as great as $14,000 \mathrm{pCi} / \mathrm{g}$, as well as sufficient quantities of volatile organic compounds to cause the material to demonstrate the Resource Conservation and Recovery Act characteristic of ignitability. Because the sludge was classified as a mixed waste, no commercial or federal facility was able to accept it for disposal. Consequently, various alternatives were evaluated to either eliminate the chemical constituents that contributed to the ignitability characteristic, or to separate the hazardous waste constituents from the radioactive constituents. A two-phased thermal treatment process was selected to eliminate the ignitability characteristic. A ventilation system was utilized in both phases to prevent the release of radioactive and heavy metal particulates and volatile organic compounds into the environment. Post-treatment analytical results verified that the treatment substantially reduced the concentrations of volatiles and semi-volatiles and eliminated the ignitability characteristic. Disposal of the treated sludge as radioactive LSA waste was approved by the disposal site in February 1989. 
$101 / 102$

\section{FACILITIES CONTAMINATED WITH NATURAL RADIOACTIVITY}


294

Bettencourt, A.O., M.M.J.R. Teixeira, M.J. Madruga, and M.C. Faisca, LNETI, Department de Proteccao e Seguranca Radiology, Sacavem, Portugal

\section{Dispersion of Radium-226 in a Contaminated Environment}

Radiation Protection Dosimetry 24(1-4):101-108; CONF-871208; The Natural Radiation Environment, Proceedings of the Fourth International Symposium, Lisbon, Portugal, December 7-11, 1987; (pp. 101-108) (1988)

A radium salts extraction factory was established in Portugal in 1908 in the northeastern part of the country. It was abandoned in the 1940s and is now in ruins. Wastes (mainly sands; highly contaminated with Ra-226 were left near these ruins. Measurements were performed to evaluate the extent of the contamination duc to the dispersion of radium around this site, using portable Geiger lube equipment as well as gamma spectrometry analyses of soil samples. Vertical profiles of soil were taken to a depth of about $40 \mathrm{~cm}$, and $5-\mathrm{cm}$ sections were analyzed by gamma spectrometry to evaluate the vertical distribution of Ra-226 and $\mathrm{Pb}-210$. Some soil characteristics, such as $\mathrm{pH}$, organic matter, and exchangeable calcium and radium were also analyzed. The dispersion of radium seems to be mostly due to the removal of contaminated wastes by mechanical means, although some leaching may have occurred. Laboratory experiments were also conducted on sandy and agricultural soils to study the leaching of Ra-226 and Pb-210 with rainwater and to help explain the results obtained in the field study. The observed influence of different parameters on this leaching are briefly discussed. Vegetables grown on these soils (mainly cabbage) were analyzed for their content of Ra-226 and $\mathrm{Pb}-210$ in order to calculate concentration factors. For Ra-226, these range from about 7 X 10(E-3) to 7 X 10(E-2). For Pb-210, they range from about $2 \times 10(\mathrm{E}-3)$ to $2 \times 10(\mathrm{E}-2)$.

\section{5}

Cliff, K.D., D.W. Dixon, J.R. Britten, P.H. Gardner, and P.A.T. Richardson, National Radiological Protection Board, Chilton, United
Kingdom; Building Research Establishment, Watford, United Kingdom; Health and Safety Exccutive, London, United Kingdom

Radon Control and Remedies in Buildings Cornwall County Council, County Architects Department, Truro, United Kingdom

Radiation Protection Dosimetry 24(1-4):531-535; CONF-871208; The Natural Radiation Environment, Proceedings of the Fourth International Symposium, Lisbon, Portugal, December 7-11, 1987; (pp. 531-535) (1988)

The Government of the United Kingdom (UK) has decided that remedial action to red ice exposure from radon daughters in existing hous s should be taken where the annual effective dose equivalent exceeds an Action Level of $20 \mathrm{mSv}$. Future houses should be designed so that the annual dose from radon daughters does not exceed an Upper Bound of 5 Msv. The Ionising Radiations Regulations 1985 impose statutory control on exposure to radon daughters in the workplace. Ficld and laboratory studies of effective methods to reciuce radon concentrations in buildings in the UK are in progress. An account of this work is presented.

\section{6}

Ericson, S.O., I. Nilsson, and H. Schmied, Swedish Courcil for Building Research, Stockholm, Sweden

\section{Radon I Dwellings - Testing and Evaluation of Constructional and Buildings Services Engincering Measures}

BFR-R-88-1988; 187 pp. (1988)

This report sets out the results of projects on remedial measures against radon. Previous and present results have been collated to provide a guide to the source and entry paths of radon. Account has been taken of the effect of external factors on the cmission of radon by building materials and of the paths taken by radon in both the soil and buildings. Within the project, different measures taken in existing and newly constructed buildings to reduce the radon conterit have been tested and evaluated. 
The radon/radon daughter content has been measured before and after remedial measure ir. existing buildings and after the construction of new buildings. The buildings included in this survey have high radon daughter contents or are situated on soil with high radon levels. The durability of the measures has been checked 1-5 years after application. The durability of the measures has been mostly satisfactory.

\section{7}

Robinet, M.J., and G.D. Mosho, Argonne National Laboratory, Argonne, IL

Volume Estimate of Radium-Contaminated Soil in a Section of Barrows Field Park, Glen Ridge; New Jersey, November-December 1989

$$
\text { ANL/ESH/TS-90/103; } 76 \text { pp. (1990, April) }
$$

The objective of this project was to estimate the in-place volume of radium-contaminated soil in an area of Barrows Field Park, Glen Ridge, New Jersey. The information was necessary to determine whether or not there was sufficient soil with the proper radium concentration to test a new method of soil decontamination. The steps used by Argonne National Laboratory personnel to obtain the required data for estimating the volume of contaminated soil was to measure the contamination-depth profile at 118 locations in a 60 -ft by 150 -ft area in the park, plot the contours of depths to the specified concentration, and measure the area of the closed depth contours.

\section{8}

Vandergaast, G., D. Moffett, and B.E. Lawrence, Eldorado Resources, Limited, Ottawa, Ontario, Canada

\section{Cleanup Around an Old Waste Site - A Success Story}

Proceedings of the Ninth Annual Canadian Nuclear Society Conference, Winnipeg, Manitoba, Canada, June 13-15, 1988, 487 pp.; (pp. 151-156) (1988, June 15)

A total of $42,500 \mathrm{cu} \mathrm{m}$ of contaminated soil was removed from off-site areas around an old, low-level radioactive waste site near Port Hope, Ontario. The cleanup was done by means of conventional excavation equipment to criteria developed by Eldorado specific to the land use around the company's waste management facility. These cleanup criteria were based on exposure analyses carried out for critical receptors in two different scenarios. The excavated soils, involving eight different landowners, were placed on the original burial area of the waste management facility. Measures were also undertaken to stabilize the soils brought on-site and to ensure that there would be no subsequent recontamination of the off-site areas. 


\section{$105 / 106$}

\section{URAINIUM MILL TAILINGS REMEDIAL ACTION PROGRAM}


299

Baublitz, J.E., U.S. Department of Energy, Washington, DC

\section{Uranium Mill Tailings: Annotation of Land Records}

Federal Register 54(134):29732-29734 (1989, July 14)

Tha U.S. Department of Energy (DOE) is issuing a proposed rule under section 109 of the Uranium Mill Tailings Radiation Control Act of 1978 for the purpose of clarifying the obligation of certain States to annotate local land records so as to ensure that the future purchases of remediated properties will be notified of the extent of work performed on their properties.

\section{0}

Caldwell, J.A., and A. Robertson, Jacobs Engineering Group, Inc., Albuquerque, NIM

Geotechnical Stability Considerations in the Design and Reclamation of Tailings Impoundments

Geotechnical Stability in Surface Mining, Proceedings of the International Symposium, Calgary, Alberta, Canada, November 6-7, 1986; (pp. 255-258) (1986)

Mine tailings impoundments are primarily geotechnical structures. By description of three case histories, the effects of geotechnical factors on the stability of tailings impoundments are discussed. When designing a new impoundment it is possible to incorporate proper consideration of appropriate reclamation procedures. Exuinples are good sites, durable materials, embankment layouts that blend with surrounding topography, and provision for final reclamation surface shapes and, where appropriate, covers. With impoundments that were completed many years ago to what are now inappropriatc standards, extensive remedial actions may be necessary to provide for long-term stabiity; work required may include relocating the pilc, reshaping the pile, and providing expensive crosion control facilities.
301

Coleman, J.A.

Uranium Mill Tailings: Annotation of Land Records

Federal Register 54(210):46072 (1989, November 1)

On July 14, 1989, the U.S. Department of Energy (DOE) issued a proposed rule to clarify the obligations of certain states to annotate the local land records of certain properties at which DOE performed remedial action to remove uranium mill tailings. In response to comments received by DOE's Uranium Mill Tailings Remedial Action Projects Office in Albuquerque, New Mexico, DOE decided to change the late and location of the public hearing and extend the comment period on the proposed rule. This action is intended to provide a more convenient opportunity for interested persons to attend the puiblic hearing and express their views.

302

Deutsch, W.J., J.W. Thackston, and D.L. Muller, Jacobs Enginecring Group, Inc., Albuquerque, NM

The Migration of Ground-Water Contaminants from Uranium Mill Tailings Piles

CONF-8609465; Geochemical Aspects of Radioactive Waste Disposal, Proceedings of a Symposium, Anaheim, CA, September 7-12, 1986; (pp. 41-42, 44) (1986)

Milling of uranium ore by acid or alkaline leaching methods produces high solution ccncentrations of both radioactive and nonradioactive species in the mill tailings piles. Seepage of solution from these tailing piles may contaminate local groundwater supplies. As part of the U.S. Department of Energy (DOE)-sponsored Uranium Mill Tailings Remedial Action Project, the movement of contaminants from the tailing piles at inactive mill tailings sites is being characterized. Study to date has shown that many of the potential contaminants, including radium and thorium, are reduced to very low solution levels as a result of water/rock interactions. However, uranium, 
sulfate, and nitrate have been found at contaminant levels in the groundwater at several sites. Spatie: distributions of contaminant concentration are used to estimate values of dispersivity and distribution coefficients by calibrating contaminant transport models to site-specific hydrologic conditions. This paper describes the existing contamination at representative sites and discusses the physical and geochemical processes that affect contaminant migiation.

\section{3}

Trikson, R.L., C.J. Hostetler, and M.L. Kemner, Pacific Northwest Laboratory, Richland, WA

Mobilization and Transport of Uranium and Uraniuisu Mill Tailings Disposal Sitcs

NUREG/CR-5169; PNL-7154; 113 pp. (1990, January)

The geochemical process of aqueous specification, precipitation, dissolution, and adsorption influence the transport of uranium at uranium mill tailings disposal sites. Traditional transport models involve the use of a single parameter, the retardation factor, to simulate the effects of these geochemical processes. Single parameter models are most applicat 12 to field situations exhibiting no changes in major element chemistry along the flow path. Recause of the changes in major slement chemistry thai occur when acidic leachaie contacts a neu ralizing soil, $:$ single parameter transport model cannot accurately capture the details of uranium migration at a number of disposal sites. We have used a chemical transport model to qualitatively describe the effects of geochemical mechanisms on uranium transport. The result is a generalized conceptual model that can reproduce the features observed at a number of uranium mill tailings disposal sites.

304

Glover, W.A., and D.N. Leske, Roy F. Weston, Inc., Albuquerque, NM; Martin Marictta Energy Systems, Inc., Oak Ridge, TN; Analysas Corporation, Oak Ridge, TN

\section{The Rules Changed}

CONF-881054 (Vol. 5); Procaedings of the 1988 Annual DOE Model Conference, Oak Ridge, TN, October 3-7, 1988; (pp. 1609-1617) (1988)

This paper presents a case study of the impact of a major mid-course change in regulatory requirements on the National Environmental Policy Act (NEPA) process at the uranium mill tailings site at Green River, Utah. When the Department of Energy's (DOE) Uranium Mill Tailings Remedial Action Project Office (UMTRA PO) began work on the Environmental Assessment (EA) for remedial action at the uranium mill tailings site at Green River, Utah, groundwater standards applicable to this activity had been remanded by the Tenth Circuit Court of Appeals. The U.S. Environmental Protection Agency (EPA) was then in the process of developing the groundwater protection standards while the draft EA was being produced. Shortly after the preliminary final EA had been sent to DOE headquarters for final review and approval, EPA published its revised groundwater protection standards (40 CFR 192). The new rules made the UMTRA project subject to a groundwater protection scheme similar to RCRA (Resource Conservation and Recovery $A c i$; requirements. It was determined that since the proposed rule was published before the preliminary final EA was approved, the EA should be updated to address how the proposed remedial action would comply. The standards set forth in the revisioni: to 40 CFR 192 were much more stringent than earlies reguirements. Before the EA could be modified, the UN.TRA PO had to devise an entirely new compliance strategy. The NEPA process was delayed, and the project buriget was impacted by the additional work. This paper will detail the iterative process by which UMTRA PO developed a satisfactory compliance strategy and met its NEPA obligations.

\section{5}

Gonzales, D.E., J.B. Millard, R. Beethe, and R.O. Murphy, Jacobs Engineering Group, Inc., Albuquerque, NM; Chem-Nuclear Environmental Services, Inc., Albuquerque, NM 


\section{Radiological Surveillances and Hcalth and Safety Audits at UMTRA Sites}

CONF-9004181; Proceedings of the U.S. Department of Energy Remedial Action Program Meeting, Albuquerque, NM, April 16-19, 1990; (3 pp.) (1990, April)

Uranium Mill Tailings Remedial Action (UMTRA) radiological surveillances and health and safety audits ensure that remedial action construction complies with all applicable regulations and requirements for the occupational, public, and environmental radiological protection and for construction safety and health. The surveillances and audits also verify that the remedial action plans and U.S. Environmental Protection Agency (EPA) cleanup standards are met. In addition, they serve to identify and resolve unanticipated procedural and design problems that otherwise could adversely impact health and safety, costs, and remedial action schedules. Specific criteria in these areas are set forth in the U.S. Department of Energy's (DOE's) UMTRA Environmental, Health and Safety Plan. The surveillances and audits of each site are conducted at least once per construction season or more frequently if the schedule is of short duration. Special situations, such as accidents, unanticipated cleanup problems, or problems which may affect the planned temedial action, trigger an immediate audit. The audit usually begins with a meeting and site orientation, followed by a comprehensive review and analyses of all radiological, health, and safety data and documentation. The auditors collect soil samples from previously verified areas for off-site analysis and provide known samples for on-site laboratory analysis to assess the accuracy of the on-site lab. The auditors' observations are discussed with site personnel during the audit. A preliminary report is prepared and discussed at the audit close-out meeting. Post-surveillance/audit activitics in Albuquerque consist of presentation and discussion of the audit results within the Environmental, Health and Safety Committee composed of senior technical assistance contractor (TAC), remedial action contractor (RAC), and DOE representatives and the auditors. A notable benefit of the internal audit/surveillance program is the improvement in project safety and radiological protection. The audit process has also contributed to reduced requirements for remediating thorium-230 contamination at processing sites and reducing requirements for remediating both thorium-230 and radium-226 at vicinity properties when these radionuclides are encountered in saturated soil. As a consequence of these reduced requirements, a proposal for not remediating radium-226 in saturated soil has been developed and changes to the EPA cleanup standards are being considered.

\section{6}

Hampill, H.G., U.S. Department of Energy, Assisiant Secretary for Nuclear Energy, Office of Remedial Action and Waste Technology, Washington, DC

\section{Hazardous and Mixed Waste Management at UMTRA Sites}

CONF-8810239; Proceedings of the U.S. Department of Energy Remedial Action Program Annual Mceting, Gaithersburg, MD, October 18-20, 1988, 555 pp.; (pp. 5.111-5.139) (1988)

During the early stages of the Uranium Mill Tailings Remedial Action (UMTRA) Project, there were some serious questions regarding the ownership of and consequently the responsibility for disposal of hazardous wastes at UMTRA sites. In addition to state and Indian Tribe waste disposal regulations, UMTRA must also conform to guidelines established by the U.S. Nuclear Regulatory Commission (NRC), Occupational Safety and Health Administration (OSHA), U.S. Environmental Protection Agency (EPA), and U.S. Department of Transportation (DOT). Because of the differing regulatory thrusts of these agencies, UMTRA has to be vigilant in order to ensure that the disposal of each pareel of waste material is in compliance with all regulations. Mixed-waste disposal presents a particularly difficult problem. No single agency is willing to lay claim to the regulation of mixed wastes, and no convertional waste disposal facility is willing to accept it. Consequently, the disposal of each lot of mixed waste at UMTRA sites must be handled on a case by case hasis. A recently published position paper which spells out UMTRA policy on waste materials indicates that wastes folnd at UMTRA sites are 
either residual radioactive wastes, or mixed wastes, or for the disposal of hazardous waste is determined by the time the original material arrived. If it arrived prior to the termination of the U.S. Atomic Energy Commission (AEC) uranium supply contract, its disposal is the responsibility of UMTRA. If it arrived after the end of the contract, the responsibility for disposal lies with the former operator.

\section{7}

Hoopes, J.R., and W.A. Glover, Jacobs Enginecring Group, Inc., Albuquerque, NM

Public Participation in the NEPA Process: Lessons Learned on the UMTRA Project

CONF-880201; Waste Management '88: Waste Processing, Transportation, Storage and Disposal - Technical Programs and Public Education, Post, R.G. (ed.), Proceedings of a Conference, Tucson, AZ, February 26-March 3, 1988, Vol. 2, 1052 pp.; (pp. 431-436) (1988)

This paper examines interactions between the U.S. Department of Energy (DOE) and the public in communities at or near Uranium Mill Tailings Remedial Action (UMTRA) Project sites where the NEPA process has been conducted. Case studies are presented illustrating public issues which have arisen resulting in impacts on the National Environmental Policy Act (NEPA) process and overall project planning. Analyses of lessons learned are offered to assist in the management of future similar efforts.

\section{8}

Ibrahim, S.A., F.W. Whicker, and S.L. Simon, Colorado State University, Department of Radiology and Radiation Biology, Fort Collins, $\mathrm{CO}$

Ground Distribution Patterns of Sclected Radioactive, Chemical, and Physical Contaminants from Dispersion of Uranium Mill Tailings

Health Physics 58(3):321-328 (1990, March)
Ground concentrations of radium-226 and total alpha activity as a function of soil depth and distance from an acidic uranium mill tailings pile were measured, as well as soil $\mathrm{pH}$, sulfate, chloride, and conductivity. Contamination decreased with increasing soil depth anil distance from the source. Most of the measured parameters were indistinguishable from background after i distance of $3.3 \mathrm{~km}$ from the tailings impoundment. The highest concentrations of all contaminants were contained in the particles less than $0.045 \mathrm{~mm}$ in diameter at the soil surface $(0-0.6$ $\mathrm{cm})$. This fraction represents only $4 \%$ to $10 \%$ of the total soil mass. Surface soil particles greater than 2 $\mathrm{mm}$ contained higher concentrations of all contaminants than the intermediate-size fraction. Aggregate formation of the greater than $2 \mathrm{~mm}$ fraction from small particles or preferential erosion and transport of the tailings sand fractions were proposed as possible explanations. The significant correlation between measurements were soil radium-226 versus total alpha activity, sulfate concentration, and conductivity. The latter two parameters are indicative of sulfuric acid leached tailings. The sulfate concentration appeared to be a sensitive and easily measured indicator of tailings contamination and migration into the soil profile. Furthermore, sulfate may be used to delineate acidic uranium tailings from other sources of contamination in the environment.

\section{9}

Jacobs Engineering Group, Inc., Albuquerque, NM

Radiological Surveillance of Remedial Action Activitics at the Processing Site - Durango, Colorado, May 16-18, 1989

Radiological Surveillance of Remedial Action Activities at the Processing Site - Durango, Colorado, May 16-18, 1989; 12 pp. (1989, May 16-18)

The Uranium Mill Tailings Remedial Action (UMTRA) Project technical assistance contractor (TAC) performed a radiological surveillance of the remedial action contractors (RACs), MK-Ferguson and Chem-Nuclear Systems, Inc., at the processing site in Durango, Colorado. This surveillance was 
conducted by Douglas E. Gonzales and Robert Murphy on May 16-19, 1989. Nine observations are presented in this report, none of which impacts the ability of the RAC to ensure compliance with the U.S. Environmental Protection Agency standards. The overall conclusion from the radiological surveillance is that health physics aspects of the Durango remedial action program are effectively performed according to written procedures and documentation requirements. No findings were made.

\section{0}

Jacobs Engineering Group, Inc., Albuquerque, NM

\section{Guidelines for Conducting Radiological Surveillances of Rernedial Action Activitics at UMTRA Processing Sites}

Report; 11 pp. (1988, May)

This document contains U.S. Department of Energy (DOE) guidelines for conducting radiological surveillances of contractors' remedial activities at uranium mill tailings sites. Radiological surveillances of the remedial action contractor's (RAC's) construction activities at DOE's Uranium Mill Tailings Remedial Action (UMTRA) processing sites are performed by the technical assistance contractor (TAC). The surveillance will specifically entail, but not be limited to: (1) review of written procedures; (2) radiological instrument calibration and documentation; (3) collection, analysis, and ultimate use of quality assurance information; (4) blind, known soils samples provided by TAC and analyzed by RAC; (5) collection of soil samples by TAC, split and analyzed independently by both TAC and RAC; and (6) a detailed, stepwise tracing of all the documentation and analysis. All observations will be discussed with RAC during the course of the surveillance and summarized in a preliminary surveillance report to be discussed at the audit closing.

\section{1}

Jacobs Engineering Group, Inc., Albuquerque, NM

\section{Durango Hcalth and Safety Audit}

Report; 5 pp. (1989, May 16-19)

The performance of the contractors and subcontractors responsible for remedial action work at the former uranium ore processing site in Durango, Colorado, was reviewed during an environmental, health, and safety audit conducted May 16-19, 1989. Occupational health and safety and environmental monitoring programs were examined by J. Millard and R. Beethe. MK-Ferguson Company is the remedial action contractor (RAC) responsible for enginecring and construction management at Durango. Chem-Nuclcar Systems, Inc., provides radiological and health physics support for the project. This was the third audit of the remedial action at the Durango site since start-up in 1986. Scveral detail items of noncompliance were identificd during the audit, resulting in eight findings and recommendations, which are listed in this report.

\section{2}

Jacobs Engincering Group, Inc., Albuquerque, NM

UMTRA Project Environmental, Health and Safety Audit Checklist

UMTRA-ESHA-2; 27 pp. (1989)

This is a blank Environmental, Health and Safety Audit Checklist form for audits of remedial action at Uranium Mill Tailings Remedial Action (UMTRA) Project remedial action sites. The audits and radiological surveillance in which this form is used are described in the other UMTRA documents accompanying it.

\section{3}

Johnson, K.O., Morrison-Knudsen Engineers, Inc., Boisc, ID

Gcochemical Aspects of Secpage from Mill Tailings

Procecdings of the 1988 Annual Socicty of Mining Engineers Meeting, Phoenix, AZ, January 25-28, 1988; (pp. 1-6) (1988) 
The large geochemical differences between tailings and groundwater create a disequilibrium in the groundwater with respect to the soils when seepage from tailings enters the groundwater. Precipitation and dissolution reactions, involving the major chemistry, occur to return the pertirbed system to chemical equilibrium between grourdw/ater and minerals. Retardation of trace elements depends upon the chemical character of the groundwater and the adsorption substrates. In the case of uranium mill tailings, the mobility of contaminants is controlled primarily by precipitation/dissolution reactions which neutralize the $\mathrm{pH}$, modify the Eh (redox potential), and produce highly adsorptive substrate for retardation of trace elements.

\section{4}

Keshian, B., Jr., and R.E. Rager, Roy F. Weston, Inc., Albuquerque, NM

\section{Geotechnical Properties of Hydraulically Placed Uranium Mill Tailings}

Geotechnical Special Publication No. 21; Hydraulic Fill Structures, Proceedings of a Symposium, Fort Collins, CO, August 15-18, 1988; (pp. 227-254) (1988)

The reclamation of 24 uranium mill tailinos piles under the U.S. Department of Energy Uranium Mill Tailings Remedial Action (UMTRA) program has provided an opportunity to compare the material properties of uranium tailings from different processing operations and different mineral belts. These results have shown that although the tailings have had different grinding processes and have come from different parts of the country, the material properties fit into a very close band of results. This paper presents the compilation and comparison of data from uranium mill tailing piles data collected as part of the UMTRA program.

\section{5}

Little, C.A., M.L. Espegren, and B.A. Berven, Oak. Ridge National Laboratory, Health and Safety Research Division, Grand Junction, CO; Oak Ridge National Laboratory, Health and Safety Research Division, Oak Ridge, TN
Progress on the UMTRA Project: The Role of the Inclusion Survey Contractor

CONF-880201; Waste Management '88: Waste Processing, Transportation, Storage and Disposal - Technical Programs and Public Education, Post, R.G. (ed.), Proceedings of a Conference, Tucson, AZ, February 26-March 3, 1988, Vol. 1, 1049 pp.; (pp. 381-386) (1988)

Oak Ridge National Laboratory serves as the Inclusion Survey Contractor (ISC) for the Department of Energy's Uranium Mill Tailings Remedial Action Project (UMTRAP). The role of the ISC is to assess whether or not each of the estimated 10,000-plus vicinity properties associated with UMTRAP is contaminated in excess of applicable standards. To date, the ISC has made recommendations on more than 8500 properties. This paper describes the flow of information through the inclusion process, the role of the ISC, and the inclusion progress to date.

\section{6}

Longley, J., J. Herrington, and M.C. Daily, Chem-Nuclear Environmental Services, Inc., Albuquerque, NM

\section{Graphical Quality Assurance and Data Management on the UMTRA Project}

Graphical Quality Assurance and Data Management on the UMTRA Project; $18 \mathrm{pp}$.

The Uranium Mill Tailings Remedial Action (UMTRA) Program was mandated by congress to remediate inactive uranium mill tailings sites primarily in th western United States. Twenty four sites in nine states were slated for remedial action. Of these states, remedial action is complete at eight, underway at five, and has not commenced at ten. Uranium mill tailings are hazardous to man because they contain elevated concentrations of radium-226, thorium-230, and other uranium decay chain nuclides. The primary exposure pathway for humans is inhalation of radon-222 which is emitted from the tailings impoundments. On the UMTRA Project, the Remedial Action Contractor (RAC) monitors for environmental radon-222, and for airborne 
radioactive particles to ensure health protection for the general public and to demonstrate compliance with DOE Order 5400.5. Because of the geographic separation of the sites and the fact that multiple actions are performed concurrently, environmental data management is of critical importance. Therefore, the Remedial Action Contractor has developed a comprehensive computer database management system for management of environmental monitoring, personnel monitoring, and soil verification data. One of the cornerstones of this database system is graphical presentation of data.

\section{7}

Metzler, D.R., K.A. Bostick, D.P. Hammermeister, and L.M. Coons, MK-Environmental Services, Inc., Grand Junction, CO

A Hydrogeologic Field Investigation of the Uranium Mill Tailings Remedial Action Project at the Cheney Tailings Disposal Site, Grand Junction, Colorado

Report; 3 pp.

Compliance with the U.S. Environmental Protection Agency (EPA) groundwater standards requires a hydrogeologic characterization of the proposed disposal site. 'This characterization is the basis for developing a water resource protection strategy that will demonstrate that the EPA groundwater standards will be met at the point of compliance. The Cheney tailings disposal site is in the Colorado plateau, in west central Colorado between the Uncompahgre uplift and Piceance basin. Located 3.5 miles from the former uranium processing mill, the Durango Colorado, UMTRA disposal cell will contain over 2.3 million cubic yards of low level radioactive material. In the fall of 1988 , a line of seepage emerged along the eastern slope of the disposal cell. Construction water and precipitation were viewed as the source of an estimated 16-20 million gallons of drainable water. By June of 1989 evaporite crystals covered an extended area of the seepage. The saturated soils and secpage prevented the placement of cover material on the eastern face. The engineered fill contained fine grained sands from the uranium milling process During relocation of the tailings over $96 \%$ compaction of the sandy material was achieved.

\section{8}

Morris, R.C., and L. Fraley, Jr., Colorado State University, Department of Radiology and Radiation Biology, Fort Collins, CO

\section{Environmental Effects on Rn-222 Fluence Rate} from Reclaimed Uranium Tailings

Bulletin of the Ecological Society of America 68(3):372 (1987, July)

The authors measured $\mathrm{Rn}-222$ fluency rate from covered uranium mill tailings with and without a clay cap and with and without vegetation. Scveral environmental variables were measured as well. Fluency rates ranged form 0.0017 to $2.0 \mathrm{~Bq} / \mathrm{sq} \mathrm{m} / \mathrm{s}$. Fluency rate was inversely related to topsoil moisture but the strongest effect was that of an interaction between vegetation and clay cap which enhanced fluency rate at least 1 order of magnitude over vegetated plots without a clay cap and bare plots with a clay cap. Vegetated, clay-capped plots commonly produced fluency rates over the EPA maximum of $740 \mathrm{mBq} / \mathrm{sq} \mathrm{m} / \mathrm{s}(20 \mathrm{pCi} / \mathrm{sq} \mathrm{m} / \mathrm{s})$.

\section{9}

Mukhopadhyay, B., and J. Fritts, Chem-Nuclear Environmental Services, Inc., Albuquerque, NM

Hazardous Organic Constituents at the UMTRA Title I Sites

Report; 8 pp.

The U.S. Department of Energy (DOE) is conducting a complete characterization of the tailings and the associated groundwaters at the Uranium Mill Tailings Remedial Action (UMTRA) sites in order io establish which of the hazardous constituents listed in the U.S. Environmental Protection Agency's Draft Final 40 CFR 192 (groundwater standards for the UMTRA sites) exceed the regulated concentrations at these sites, and pose potential risks to human health and the environment. This characterization is essential for demonstrating 
compliance with the Subpart A of 40 CFR 192 (Tailings Disposal) and for establishing the foundation for ccinpliance with subpart B (Groundwater Remcdiation). This paper deals with the results of a screening for the hazardous organic constituents (HOC) at the above UMTRA sites in order to determine whether detailed HOC investigations are needed at any of these sites. The HOC were screened using the EPA suggested analytical methods (40 CFR 264) and in accordance with the EPA quality assurance program. The results are shown in the table attached to this document. The results show that a small amount of toluene appears present in the groundwater beneath the tailings pile of the New Rifle site (RFN).

320

U.S. Department of Energy, Albuquerque Operations Office, Uranium Mill Tailings Remedial Action Project Office, Albuquerque, NM

Environmental Assessment of Remedial Action at the Monument Valley Uranium Mill Tailings Site, Monument Valley, Arizona

DOE/EA-0368; 149 pp. (1989, June)

This document assesses the environmental impacts of the excavation and transport of the Monument Valley contaminated materials and borrow materials to the Mexican Hat, Utah, disposal site. In addition, impacts that would be changed at the Mexican Hat site as a result of moving the Monument Valley contaminated materials to the Mexican Hat site are reanalyzed in this document. The Monument Valley site consists of two tailings piles and other contaminated areas, such as an evaporation pond, heap leach pads, ore storage areas, a batch leach yard, and areas contaminated by windblown tailings. From 119 acres of disturbed land, a total of 983,000 cubic yards of contaminated material would be moved to Mexican Hat. An additional 152 acres would be disturbed during excavations at the borrow sites and in widening the haul road between the sites. Attached to the EA is a Finding of No Significant Impact by DOE dated May 31, 1989, signed by P.N. Brush, Acting Assistant Secretary, Environment, Safety, and Health.
321

U.S. Department of Energy, Albuquerque Operations Office, Uranium Mill Tailings Remedial Action Project Office, Albuquerque, NM

\section{Remedial Actions at the Former Union Carbide Corporation Uranium Mill Sites, Rifle, Garfield County, Colorado - Final Environmental Impact Statement, Volume I: Text}

DOE/EIS-0132-F (Vol. I); 408 pp. (1990, March)

The final environmental impart statement (EIS) is given for proposed remedial actions, the cleanup of contaminated materials at the mill sites and associated vicinity properties at Rifle, Colorado, designated by the Uranium Mill Tailings Radiation Control Act (UMTRA) of 1978. This statement evaluates and compares the environmental impacts associated with the remedial actions for the residual radioactive materials remaining at the inactive uranium processing sites at Rifle. The Rifle sites consist of the separate Old and New Rifle tailings sites, which cover 164 acres of private land and contain approximately 4,135,000 cubic yards of tailings and associated contaminated soils. The tailings were produced by the Union Carbide Corporation when in processed vanadium and uranium ores from 1924 to 1932 and from 1942 to 1973. The U.S. Atomic Energy Commission purchased uranium from the sites from 1949 to 1971; additional uranium and all the vanadium were sold to commercial buyers. This statement evaluates interim actions at both processing sites for all four alternatives and three action alternatives for the stabilization and disposal of the tailings and other contaminated materials. The alternatives are: (1) No remedial action; (2) Stabilization at the New Rifle site; (3) Disposal at the Estes Gulf site; and (4) Disposal at the Lucas Mesa site. Alternative (3) is the DOE's preferred alternative. Issues in this final EIS include areas of controversy raised during the public comment period and issues to be resolved. The final EIS also contains several changes from the draft EIS of May, 1987. 
322

U.S. Department of Energy, Albuquerque Operations Office, Uranium Mill Tailings Remedial Action Project Office, Albuquerque, NM

\section{Remedial Actions at the Former Union Carbide Corporation Uranium Mill Sites, Rifle, Garfield County, Colorado - Final Environmental Impact Statement, Volume II: Appendices}

DOE/EIS-0132-F (Vol. II); 524 pp. (1990, March)

These are the appendices of the final environmental impact statement (EIS) for proposed remedial actions, the cleanup of contaminated materials at the mill sites and associated vicinity propertics at Rifle, Colorado, designated by the Uranium Mill Tailings Radiation Control Act (UMTRA) of 1978. Appendices $\mathrm{C}, \mathrm{H}, \mathrm{I}, \mathrm{J}$ and $\mathrm{K}$ were printed in the Draft EIS of May, 1987, and since no substantive changes were made in them, they are incorporated by reference only in this Final EIS. Appendix A (Conceptual Designs) provides the information needed to understand the conceptual designs for the remedial action alternatives addressed in this EIS. It is intended to provide sufficient details for the r"ader to evaluate the feasibility and assess the impacts of each remedial action alternative. It is not intended to provide the detailed engineering necessary to implement the alternatives. The alternatives are: (1) No remedial action; (2) Stabilization at the New Rifle site; (3) Disposal at the Estes Gulf site; and (4) Disposal at the Lucas Mesa site. Alternative (3) is the DOE's preferred alternative. Details of the preferred remedial action will be presented in the remedial action plan. Appendix B describes the detailed process of selecting the altcrnate disposal sites used by DOE and the state of Colorado. Appendix $D$ is a characterization of soils, geology, and seismicity for the sites, while Appendix $\mathrm{E}$ is a hydrological evaluation of the study area and sites. Appendix $F$ describes the impacts of the alternatives on the floor olains and wetlands of the Colorado River adjacent to the Rifle sites. Appendix $G$ describes the vegetation, fish, and wildlife baseline at the various sites, including threatened, endangered, and sensitive species.
323

U.S. Department of Energy, Assistant Secretary for Nuclear Encrgy, Office of Remedial Action and Waste Technology, Washington, DC

\section{Annual Status Report on the Uranium Mill Tailings Remedial Action Program}

\section{DOE/NE-0025/4; 62 pp. (1987, December)}

This ninth Annual Status Report summarizes activities of the Uranium Mill Tailings Remedial Action (UMTRA) Project undertaken during fiscal year (FY) 1987 by the U.S. Department of Energy (DOE) and other agencies. Project goals for FY 1988 are also presented. An annual report of this type was a statutory requirement through January 1 , 1986, pursuant to the Uranium Mill Tailings Radiation Control Act (UMTRCA) of 1987, Public Law (PL) 95-6()4. DOE will continue to submit this report through project completion in order to fully inform the public of yearly project status.

\section{4}

U.S. Department of Energy, Office of Remedial Action and Waste Technology, Washington, DC

Annual Status Report on the Uranium Mill Tailings Remedial Action Program

DOE/NE-()025/4 (88); $32 \mathrm{pp.}$

This tenth Annual Status Report summarizes activitics of the Uranium Mill Tailing: Remedial Action (UMTRA) Project undertaken during FY 1988 by the U.S. Department of Energy (DOE) and other agencies. Project goals for FY 1989 are presented. Assessment and remedial action to control uranium mill tailings and other residual radioactive matcrials at 22 . designated inactive uranium processing sites and vicinity properties are summarized. UMTRA completed the following processing site remedial actions: $92 \%$ of Lakeview, Oregon; $60 \%$ of Durango, Colorado; $65 \%$ of Tuba City, Colorado; $40 \%$ of Riverton, Wyoming; and $7 \%$ of Ambrosia Lake, New Mexico. Remedial action was initiated at Rifle, Colorado, Green River, Utah, and Mexican Hat, Utăh. Remedial action contracts were initiated on 895 vicinity propertics for eight designaled siles, and inclusion decision activities 
were completed on 425 vicinity propertics. Significant progress was made on completion of remedial action of complex commercial properties in Durango, Colorado, Findings of No Significant Impacts (FONSIs) were issued for Green River, Utah, and Mexican Hat, Utah. Final Environmental Impact Statement (EIS) and Record of Decision (ROD) were issued for Grand Junction, Colorado. Final Environmental Assessment (EA) was issued for Green River, Utah; draft EAs were issued for
Belfield and Bowman, North Dakota, Falls City, Texas, and Spook, Wyoming. Remedial Action Plans (RAP) were completed for Green River and Mexican Hat, UT, and Ambrosia Lake, New Mexico. Draft RAPs were prepared for Belfield and Bowman, North Dakota, and Monument Valley, Arizona. Appendices to the report include program funding, figures and tables, coinments from i affected states, and 12 photographs of remedial actions. 


\section{URANIUM MILL TAILINGS \\ MANAGEMENT}


325

Bejarano, J.D., F.V. Tome, A.M. Sanchez, and A.R. Sanchez, Extremadura University, Departmento de Fisica, Badajoz, Spain

Contamination in Surface Waters Around Uranium Mincs in the Guadiana Basin

Radiation Protection Dosimetry 24(1-4):149-153; CONF-871208; ['he Natural Radiation Environment, Proceedings of the Fourth International Symposiurn, Lisbon, Portugal, December 7-11, 1987; (pp. 149-153) (1988)

In a study of contamination by uranium mines in the River Guadiana basin, the authors have found the natural higher concentration of uranium in samples collected near the mines and the expected decreases with distance in samples farther away. In spite of this expected result, there is another interesting fact: a nalural isotopic separation is observed. Measurements were by alpha spectrometry with a silicon surface barricr detector. The study was completed with total gamma activity at the same sites as for alphas, using an NaI(TI) detector.

\section{6}

Constable, T.W., and W.J. Snodgrass, Environment Canada, Environmental Protection Service, Ottawa, Ontario, Canada

\section{Leachability of Radioactive Constitucnts from Uranium Mine Tailings}

EPS-3/MM/2 (1987)

A scries of long-term studies were conducted both to examine the leacnability of major constituents (acidity, TDS) and radioisotopes from uranium mining/milling tailings and settling pond sludges, and to asiess the effect of two trearment methods (solidification and vegetation) on leachate characteristics. Four bench-scale experiments were conducted to examine the leachability of: (1) old tailings and those containing a large portion of (Ba,Ra)SO4 sludges, (2) untreated and solidified (Ba,Ra)SO4 sludges located at the bottom of settling ponds, (3) new tailings that had been vegetated or solidified, and (4) new tailings suhject to varying flow rates. A fifth study was conducted to examine the microbiology of Experiments 2 and 3.

\section{7}

Eidson, A.F., Inhalation Toxicology Research Institute, Albuquerque, NM; U.S. Nuclear Regulatory Commission, Washington, DC

\section{Biological Characterization of Radiation Fixposure and Dose Estimates for Inhaled Uranium Milling Eflluents}

NUREG/CR-5489; LMF-124; 85 pp. (1990, June)

The problems addressed are the protection of uranium mill workers from occupational exposure to uranium through routine bioassay programs and the assessricent of accidental worker exposures. Comparisons of chemical properties and the biologica! behavior of refined uranium ore (ycllowcake) are made to identify important properties that influence uranium distribution patterns among organs. These studies will facilitate calculations of organ doses for specific exposures and associated health risk estimates and will identify important bioassay procedures to improve evaluations of human exposures. Samples of airborne uranium from operating mills and deposition models were used to predict appreciable deposition rates in the upper respiratory tract of workers, if respiratory protection were not used. A biokinetic model of retention and excretion of yellowsake inhaled by Beagle dogs was developed. Comparison of the results with available data from human exposures showed that organ burdens in an exposed worker can be estimated from urinary bioassay results and in vivo counting, if the chemical composition, or soluble fraction, of the inhaled yellowcake is known.

\section{8}

Fernande:, F., C.F. Figueroa, J.M.C. Gomez, and J.C. Lozano, Salamancia University, Laboratoric de Radiactividad Ambiental, Salamacia, Spain 
Impact of Uranium Mining on the Radioactive Contamination of the Agueda River

Radiation Protection Dosimetry 24(1-4):155-158; CONF-871208; The Natural Radiation Environment; Proceedings of the Fourth International Symposium, Lisbon, Portugal, December 7-11, 1987; (pp. 155-158) (1988)

Gross alpha activity was measured in water from the Agueda River, which flows through the most important uranium mine in Spain near the Portuguese border. The study covers the period from October 1984 to April 1985 and a stretch of 45 $\mathrm{km}$, with the mine situated in the middle. The water was evaporated to dryness and counted in a planchet under a zinc sulphide scintillation counter. The average alpha activity was found to be less than 0.01 $\mathrm{Bq} / \mathrm{l}$ upstream from the mine; it increases suddenly in front of the effluent discharge from the mine, and then decreases rapidly and becomes roughly stable at around $0.06 \mathrm{~Bq} / \mathrm{l}$. The technique for planchet preparation is also discussed and the efficiency factor as a function of dry residue is shown to be accurately described with a theoretical formula based on exponential absorption, but also including geometrical effects.

329

Gulson, B.L., K.J. Mizon, M.J. Korsch, B.N. Noller, I.K. Dibobes, A.G. Trusov, V.A. Ryabov, and R.M. Aleksakhin, CSIRO, North Ryde, Australia

\section{Lead Isotopes as Seepage Indicators Around a Uranium Tailings Dam}

\section{Environmental Science and Technology} 23(3):290-294 (1989)

Lead isotope ratios and lead concentrations have been measured in water from 26 bores around the Ranger uranium tailings dam, Northern Territory, Australia, and from the dam itself to determine possible migration of lead derived from the radioactive decay of uranium. Lead isotope compositions have also been measured for the particulates retained on selected filters. The concentration of lead in the bore waters is extremely low (usually less than $1 \mathrm{ppb}$ ). The $\mathrm{Pb}-206 / \mathrm{Pb}-204$ ratio measured in the bore waters differs hy more than a factor of 100 from that in the tailings dam and shows no evidence of lead derived from a significant uranium accumulation. It may br possible to distinguish between lead from the tailings dam and that derived from a nearby uranium ore body.

\section{0}

Hendry, L., Ayrshire Radiation Monitoring, Fairlie, United Kingdom; Cowal Monitoring Group, Dunoon, United Kingdom

\section{Health Effects of Jranium Mining}

CONF-8806409; Low-Level Radiation and Health, Proceedings of a Standing Conference, Stirling, United Kingdom, June 25-26, 1988; (pp. 62-62) (1988)

This outline sketch mentions cause for concern in the Orkney corridor, deep, and open-cast mines in Australia, New Mexico (where radioactive mill tailings have been used in construction work); the Navajo, Indian Lands; and Namibia. "Partizans" activities are mentioned in relation to Rio Tinto Zinc.

\section{1}

Jeffery, J.J., G. Sinclair, and R.T. Lowson, Australian Nuclear Science and Technology Organization, Lucas Heights, Australia

\section{Radium and Heavy Metal Transport Bencath an Abandoned Uranium Tailings Dam}

ANSTO/E-675; 17 pp. (1988, September)

An abandoned uranium tailings dam at Moline in the Northern Territory of Australia was the site of a study to assess the movement of potentially toxic elements irom tailings into subsoil. The tailings at Moline were first laid down in 1959 and have since been leached by prevailing rainfall. Sixteen sampling sites were selected to give a good representation of the dam. At each site, a trench was excavated through the tailings and into the subsoil; then samples of subsoil were taken at $10-\mathrm{cm}$ intervals 
down to a depth of $50 \mathrm{~cm}$. A sample of the tailings overlying the tailings-subsoil interface was also taken. Samples were analyzed for radium, uranium, copper, zinc, and lead. At most sites there was only minor accumulation of these elements in the $0-$ to $10-\mathrm{cm}$ subsoil layer immediately below the interface, with concentrations typically orie or two orders of magnitude less than the concentrations in overlying tailings. Below $10 \mathrm{~cm}$, the concentrations were typically at or close to background concentrations.

332

Mahdy, M.A., Egyptian Society of Nuclear Sciences and Applications, Cairo, Egypt

Extraction of Uranium, Thorium and Radium from an Elliot Lake Radioactive Ore by Chlorine-Assisted Leaching

CONF-8803238; Nuclear Sciences and Applications, Proceedings of a Conference, Cairo, Egyp., March 6-10, 1988, 429 pp.; (1 p.) (1988)

Present commercial uranium leaching technology by sulfuric acid causes at lot of environmental problems including dissolution of neavy metal nuclides like Co, $\mathrm{Cu}, \mathrm{Ni}$, and $\mathrm{Mo}$ and highly toxic radionuclides like Th-230, Ra-22f, and Pb-210. A new trend has heen adopted in Canada and elsewhere for achieving new uranium extraction techniques avoiding such environmental problems. This work is orientcd to study the factors controlling the chlorine-assisted leaching and to investigate the suitability of this technique to meet this trend. In bench-scale experiments, chlorine-assisted leaching has been proved to be efficient to extract $97 \%$ of uranium and $87 \%$ of thorium using $0.5 \mathrm{~g} \mathrm{Cl} 2 / \mathrm{G}$ Elliot Lake radioactive ore after $4 \mathrm{~h}$ agitation at $90 \mathrm{C}$ with a solid liquid ratio of 1:1. However, extractions of radium and rare earth elements using the same factors were inadequate.

333

Mahdy, M.A., Egyptian Society of Nuclear Sciences and Applications, Cairo, Egypt

\section{Hydrochloric Acid Leaching of Uranium, Thorium, Radium and Rare-Earth Elements, from an Elliot Lake Radioactive Ore}

CONF-8803238; Nuclear Sciences and Applications, Proceedings of a Conference, Cairo, Egypt, March 6-10, 1988, 429 pp.; (1 p.) (1988)

Extraction of uranium by commercial methods using sulfuric acid developed a lot of environmental problems. To avoid such problems, other uranium extraction techniques have been adopted including fluorination, chlorination, chlorine assisted leaching, hydrochloric acid leaching, etc. This work is oriented towards the study of the factors controlling the hydrochloric acid leaching. The target of the study is to extract the total amount of uranium, thorium, Ra-226, and rare earth elements. By using a suitable combination of the leaching factors, it was possible to achieve the designed target.

\section{4}

Mathur, A.K., and K.K. Dwivedy, Department of Atomic Energy, Atomic Minerals Division, Hyderabad, India

Biogenic Approach to the Treatment of Uranium Mill Effluents

Uranium (Netherlands) 4(4):385-394 (1988, September)

A biogenic method for the treatment of uranium mill effluents containing toxic amounts of $\mathrm{Mn}(+2)$ and Ra-226 is described. The acidic tailings from the uranium mills are generally neutralized with lime and the overflow waters from tailing ponds at the discharge point, consisting of $\mathrm{Mn}(+2) /$ (greater than $10 \mathrm{mg} /$ ) and $\mathrm{Ra}-226$ (greater than $3.0 \mathrm{pCi} /$ ), need further treatment before disposing off to the public utility. Arthrobacter sp. has been used for precipitating $\mathrm{Mn}(+2)$ as hydrous oxide of manganese (MnO2 complexed with $\mathrm{H} 2 \mathrm{O}$ ) and along with Ra-226 also gets precipitated. The effluent after bacterial treatment consisted of $\mathrm{Mn}(+2)$ and $\mathrm{Ra}-226$ within the range of allowed concentrations as per the International Committee of Radiological Protection 
(ICRP) and maximum permissible concentration (MPC).

335

Morris, R.C., and L. Fraley, Jr., Colorado State University, Fort Collins, $\mathrm{CO}$

Effects of Vegetation, A. Clay Cap and Environmental Variables on Rn-222 Fluence Rate from Reclaimed Uranium Mill Tailings

Health Physics 56(4):431-440 (1989, April)

We measured Rn-222 fluency rate and several environmental variables on two plots with uranium mill tailings buried beneath $30 \mathrm{~cm}$ oi overbur den and $20 \mathrm{~cm}$ of topsoil. An additional $30 \mathrm{~cm}$ of clay covered the tailings on one plot ard each plot was subdivided into bare soil and vegetated subplots. We used linear correlation, two-way ANOVA and stepwise multiple regression to analyze the effects of the plot characteristics and the environmental variables on $R n-222$ fluency rate. The most important effect on $\mathrm{Rn}-222$ fluency rates from these plots was the combination of a clay cap and a vegetaied surface. The mean annual fluency rate from the plot having both of these characteristics $(520+/-370 \mathrm{mBq} / \mathrm{sq} \mathrm{m} / \mathrm{s})$ was over three times that of the vegetated plot without a clay cap $(170+/-130$ $\mathrm{mBq} / \mathrm{sq} \mathrm{m} / \mathrm{s}$ ) and 18 times that of the bare plot with a clay cap $(29+/-13 \mathrm{mBq} / \mathrm{sq} \mathrm{m} / \mathrm{s})$. The interaction effect may have been due to the growth of roots in the moist clay and active transport of dissolved $\mathrm{Rn}-222$ to the surface in water. This speculation is supported by the observation that on vegetated plots with a clay cap, moisture in the clay enhanced the fluency rate.

336

Pickup, G., R.J. Wasson, R.F. Warner, D. Tongway, and R.L. Clark, Commonwealth Scientific and Incustrial Research Organisation, Division of Water Resources Rescarch, Canberra, Australia

Feasibility Study of Geomorphic Rescarch for the Long Term Management of Uranium Mill Tailings
Commonwealth Scientific and Industrial Research Organisution (CSIRO), Publisher, Canberra, Australia (1987)

This report provides a plan for geomorphic research needed for proper long-term management of mill tailings from the Ranger uranium mine in the Northern Territory of Australia. The proposed research will provide information about both the risk of above-grade disposal of the tailings and the implications of the escape of tailings from containment structure. The proposed research includes the description of, documentation of behavior of, and the identification of controlling external forces on, the geomorphic system both at the mine site and in a much larger area likely to be affected by escaped tailings. While designed for the Ranger site, the principles embodied in this report are applicable to many problems of mine waste disposal.

\section{7}

Radtke, S.A.

White King/Luck Lass Mine Remedial Action Project, Frecmont National Forest, Lake County, OR

Federal Register 54(153):32837-32838 (1989, August 10)

The Forest Service will prepare an environmental impact statement (EIS) for assessment and remedial action of the White King and Luck Lass abandoned uranium mines on the Lakeview Ranger District, Freemont National Forest, Lake County, Oregon. Th. : EIS will tier to the Freemont National Forest Land and Resource Management Plan of May 12, 1989, which provides overall guidance in achieving the desired future condition for the area. The agency invites written comments and suggestions on the scope of the analysis. In addition, the agency gives notice of the full environmental analysis and decision-making process that will occur on the proposal so that interested and affected individuals and organizations are aware of how they may participate and contribute to the final decision. 
338

U.S. Congress, House of Representatives, Committee on Ways and Means, Washington, DC

\section{Uranium Enrichment and Mill Tailings Reclamation Legislation}

U.S. Congress, House of Representatives, Committee on Ways and Means, Washington, DC, One Hundredth Congress, Second Session, August 10, 1988, Serial 100-79:90-968. U.S. Government Printing Office, Washington, DC, $1988 ; 120$ pp. (1988, August 10)

The House Committce on Ways and Means scheduled a hearing on August 10, 1988, on bills rela:ing to promotion of domestic uranium mining and financing of uranium enrichment and uranium mill tailing reclamation. The bills include H.R. 4489 (Richardson, et al.), H.R. 4934 (Richardson and Hubbard), and H.R. 4975 (Niclson, et ai.). These bills would establish a Federal fund to assist in financing of reclamation and other remedial action at currently active uranium and thorium processing sites, and would establish a wholly owned government corporation to operate the federal uranium enrichment program as a continuing, commercial enterprise. They would promote the domestic uranium mining industry, either by imposing a charge on foreign uranium contained in nuclear reactor fuel assemblies or by authorizing funds for the purchase of domestic uranium by the federal government. This document provides background and a summary description of the bills and related issues before the Committee on Ways and Means.

Uranium Mill Facilities: Availability and Request for Public Comment on Draft Technical Position on Design of Erosion Protection Covers

Federal Register 54(154):33101 (1989, August 11)
The Nuclear Regulatory Commission (NRC) is announcing the availability of and is requesting public comment on a draft Staft Technical Position entitled "Design of Erosion Protection Covers for Stabilization of Uranium Mill 'Tailings Sites." The position provides guidance on acceptable methods for meeting the long-term stability requirements established in $10 \mathrm{CFR}$ Part 40, Appendix $A$ and in 40 CFR Part 192, with regard to the design of erosion protection covers. NRC is requesting public comment on the draft Technical Position before it is finalized.

\section{0}

Wand, U., and G. Strauch, Akademie der 'Wissenschaften der DDR, Zentralinstitut fuer lsotopen- und Strahlenforschung, Leipzig, German Democratic Republic

\section{Influence of Mining Activity on Distribution of Radium in the Natural Environment}

CONF-8609332; Isotopes in Nature, Proceedings of a Working Mecting, Leipzig, German Democratic Republic, September 22-26, 1986; (pp. 423-428, 688) (1987)

Recent investigations indicated that not only uranium mining but also other mining activities cause radioactive pollution of the natural environment. This has also been found in coal mining areas of West Germany and Poland. In the Upper Silesian Coal Basin, radium bearing waters with Ra-226 concentration reaching $270 \mathrm{kBq} / \mathrm{cu} \mathrm{m}$ are observed. The water pumped out of mines increases radium concentration in brooks and rivers. Since it often contains $\mathrm{Ba} 2+$ ions, radioactive precipitates are formed and deposited throughout river beds. Concentration of $\mathrm{Ra}-226$ in the deposits is sometimes as high as $130 \mathrm{kBq} / \mathrm{kg}$. High radium content in soil and in plants was also observed.

\section{1}

Whitehead, W., Atomic Energy Control Board, Ottawa, Ontario, Canada

Decommissioning of Uranium Mines and Mills Canadian Regulatory Approach and Experience 
INFO-0219; CONF-8609486; Radioactive Waste Management, Proceedings of a Canadian Nuclear Society International Conference, Winnipeg, Ontario, Canada, September 7-11, 1986; (33 pp.) (1986, September)

At the time of the recent closures of the Agnew Laka. Beaverlodge, and Madawaska Mines Limited uranium mining and milling facilities, several relevant regulatory initiatives, including the developmest of decommissioning criteria, were under way, or contemplated. In the absence of precedents, the regulatory agencies and companies involved adopted approaches to the decommissioning of these facilities that reflected site specific circumstances, federal and provincial regulatory requirements, and generally accepted principles of good engineering practice and environmental protection. This paper summarizes related historical and current regulatory policies, requirements, and guidelines, including those implemented at the three decommissioned sites. 
$125 / 126$

TECHNICAL MEASUREMENT CENTER 
342

Pearson, M.D., UNC Geotech, Inc., Grand Junction, $\mathrm{CO}$

\section{Calibration of Alpha-Track Monitors for Measurements of Thoron}

DOE/ID/12584-61; UNC/GJ-51(TMC); 26 pp. (1990, March)

Several types of commercial alpha-track monitors are supplied in a standard configuration with filters that are permeable to both radon ( $\mathrm{Rn}-222)$ and thoron (Rn-220). Thesu monitors can be modified to exclude thoron oy the choice of a diffusion barricr such that the diffusion time across the barrier takes much longer than the half life of thoron $(55.6 \mathrm{sec})$. Devices with and without thoron diffusion barriers can be simultaneously exposed to determine the thoron exposure once an aplropriate calibration factor for thoron has been determined. Filtered alpha-track devices are available for average-integrated measurements of radon. The devices contain plastic detector material that registers damage tracks when exposed to alpha particles from the decay of radon and its progeny. The detector material is sensitive to any alpha particle, however, and will also register damage tracks due to alpha particles from the decay of thoron and its progeny when thoron is present in the atmosphere that is sampled.

\section{3}

Rangel, M.J., D.E. Martz, and G.H. Langner, Jr., UNC Geotech, Inc., Technical Measurements Center, Grand Junction, CO

\section{Gamma and Beta Logging of Underground Sewer and Process Lines}

DOE/ID/12584-45; 17 pp. (1989, November)

The UNC Geotech Radon Laboratory was assigned the task of developing a gamma-sensitive field instrument that would be capable of detecting the presence of uranium mill tailings used as backfill in sewer line trenches on commercial and residential properties in the Grand Junction area. A waterproof gamma detector mounted on a sewer snake, inserted into the clean-out access port, and pushed down the sewer line 45 to $90 \mathrm{fect}$, represented a promising field assessment tool for this purpose. A small sodium iodide gamma detector was expected to be capable of detecting the presence of tailings in the backfill without relying on extensive surveying and drilling. The instrument designed for this purpose was termed the GammaSnake. The original concept of the GammaSnake was extended to include a beta-sensitive detector that could be inserted into underground process lines for determining the presence and location of residual beta emitting isotopes at formerly utilized DOE facilities. The instrument developed for this purpose was termed the BetaSnake.

\section{4}

Rood, A.S., J.L. George, and G.H. Langner, Jr., UNC Geotech, Inc., Technical Measurements Center, Grand Junction, CO

Variation in the Annual Ave age Radon Concentration Measured in Homes in Mesa County, Colorado

DOE/ID/12584-57; UNC/GJ-50(TMC); 29 pp. (1990, April)

The Technical Measurements Center (TMC) has measured annual average indoor radon concentrations at 49 sampling stations in 33 residential structures over a 5-year period for the purpose of determining the year-to-year variation in the annual average radon concentration in homes in Mesa County, CO. One to three Terradex Track Etch Type SF radon monitors were deployed for 1-year periods at each sampling location. The structures used in the study were representative of middle income families. Thirty of the 49 sampling stations had complete data for the 5-ycar study period. These data were used to determine the variation in the annual average radon concentration. Variation in the annual average radon measurement at each sampling station was expressed in terms of the coefficient of variation (standard deviation/mean). The range of radon concentrations measured in the 30 sampling stations with 5 ycars of data was between $7.4 \mathrm{~Bq} / \mathrm{cu} \mathrm{m}$ and $444 \mathrm{~Bq} / \mathrm{cu} \mathrm{m}$. The variability inherent in the radon measurement was factored out of the observed measured variability to 
obtain the variability in the annual average radon concentration. This variation was $22 \%$. Basement radon concentrations were higher than ground-level

or first floor radon concentrations in all cases. This is a continuing study, and this report presents the data that have been collected and processed to date. 
$129 / 130$

REMEDIAL ACTION PROGRAM 
345

Bresec, J.C., S.P. Cowan, and J.E. Baublitz

Integrated Data Base for 1989 - Spent Fucl and Radioactive Waste Inventories, Projections, and Characteristics

DOE/RW-(0)()6 (Rev. 5); 216 pp. (1989, November)

The Integrated Data Base (IDB) Program has compiled current data on inventorics and characteristics of commercial spent fucl and both commercial and U.S. government-owned radioactive wastes through December 31, 1988. These data are based on the most reliable information available from government sources, the open literature, technical reports, and direct contacts. The current projections of future wastes and spent fucl to be generated through the year 2020 and characteristics of these materials are also presented. The information forecasted is consistent with the latest U.S. Department of Energy/Encrgy Information Administration (DOE/EIA) projections of U.S. commercial nuclear power growth and the expected defense-related and private industrial and institutional (1/I) activitics. The radioactive materials considered, on a chapter-by-chapter basis, are spent fuel, high-level waste, transuranic waste, low-level waste, commercial uranium mill tailings, remedial action waste, commercial reactor and fucl cycle facility decommissioning waste, and mixed (hazardous and radioactive) low-level waste. For most of these categories, current and projected inventories are given through the year 2020, and the radioactivity and thermal power are calculated based on reported or estimated isotopic compositions. In addition, characteristics and current inventories are reported for miscellaneous, highly radioactive materials that may require geologic disposal.

\section{6}

Chen, S.Y., and Y.C. Yuan, Argonne National Laboratory, Argonne, IL

Effectiveness of Clcanup Criteria Relative to an Accident Nuclcar Release
Transactions of the American Nuclear Socicty 57:167-169); Nuclear Fission, Proceedings of the 1988 International Conference, Washington, DC, October 30-November 4, 1988 (1988)

In the event of an accidental nuclear release, the associated long-term radiological risks would result primary from ground contamination pathways. Cleanup of the contaminated ground surfaces is a necessary step toward reducing the radiological risk to the gencral population. Ideally, the radiological risk decreases as the level of cleanup effort increases; however, as the cleanup criterion (i.e., the required contaminant concentration after cleanup) becomes more stringent, the cleanup effort may become prohibitively costly. The authors examine several factors that are important in determining the effectiveness of the cleanup criteria for selected radionuclides: (a) annual individual dose commitment (mrem/yr), (b) total population cnvironmental dose commitment (person-rem), and (c) total area (sq $\mathrm{km}$ ) requiring cleanup following an accident.

347

Davis, J.P., General Physics Corporation, Columbia, MD

\section{The Future of the de Minimis Concept}

Health Physics 55(2):379-382; Radiation Protection - A Look to the Future, Procecdings of the 25th Hanford Life Sciences Symposium, Richland, WA, October 21-23, 1986; (4 pp.) (1988, August)

How low is low cnough? Is "close to zcro" equivalent to zero? Does detectability define importance? These and similar questions are addressed in this paper, which considers the concept of a "practical zero" or "de minimis" level of radiation and the future applications of that concept. After defining the concept and some widely used terms and summarizing the current status of the de minimis approach, this article surveys the activities of standards-setting and regulatory bodics throughout the world and their possible future approaches to applying the de minimis concept. Applications 
include conventional disposal of very low-level wastes, ocean dumping, decontamination and decommissioning guidelines, and truncation of as low as reasonably achievable and collective dose calculations. Implications in areas beyond low-level radiation control are also addressed. These areas include nuclear accident risks and the risks associated with use of hazardous materials. The application of the de minimis concept to risks of all types is discussed, with a particular emphasis on the risks of carcinogenesis. The paper also presents a summary of methods for quantitatively setting actual levels that are deemed de minimis in specific cases. Finally, the problems inherent in a de minimis approach are discussed and an attempt is made to predict future developments

\section{8}

Green, S., Jacobs Engineering Group, Inc., St. Charles, MO

A Field Study Designed to Select the In-Situ Instrumen' Most Useful for Estimating Uraniurn Contamination in Soil

CONF-880201; Waste Management '88: Waste Processing, Transportation, Storage and Disposal - Technical Programs and Public Education, Post, R.G. (ed.), Proceedings of a Conference, Tucson, AZ, February 26-March 3, 1988, Vol. 1, 1049 pp.; (pp. 695-702) (1988)

A requirement for any remedial action involving a site contaminated with radionuclides from the natural series is a field instrument capable of quickly estimating land areas which exceed cleanup guidelines. Much work has been done on uranium mill tailings sites in which a major contaminant was Ra-226. Considering the high energy gamma radiation emitted by $\mathrm{Ra}-226$ daughter products, it is not surprising that detector configurations using a NaI scintillometer operating in a gross count mode have proven quite useful. Remedial actions are now underway on sites primarily contaminated with uranium not in secular equilibrium with its daughter products (limited Ra-226). In this situation, the choice of the proper field instrument becomes le is clear. This paper presents the results of a ficld study designed to select the instrument most appropriate for detecting uranium in excess of remedial guidelines. The instruments tested were a shielded pancake Geiger-Mueller detector, a field instrument for detecting low energy radiation (FIDLER) operated in the gross count mode and the single channel mode, and an unshielded $2 \times 2$-inch $\mathrm{NaI}$ scintillometer.

\section{9}

Kocher, D.C., Oak Ridge National Laboratory, Oak Ridge, TN

\section{Classification and Disposal of Radioactive Wastes: History and Legal and Regulatory Requirements}

CONF-900679; Proceedings of the 1990 Annual Health Physics Society Meeting, Anaheim, CA, June 24-28, 1990; (88 pp.) (1990)

This document discusses the laws and regulations in the United States addressing classification of radioactive wastes and the requirements for disposal of different waste classes. This review emphasizes the relationship between waste classification and the requirements for permanent disposal.

350

Owen, P.T., Oak Ridgye National Laboratory, Oak Ridge, TN

An Overview of Remedial Action Technical Information Support Activities Funded by the U.S. Department of Energy's Office of Environmental Restoration

CONF-9004181; Proceedings of the U.S. Department of Energy Remedial Action Program Mecting, Albuquerque, NM, April 16-19, 1990; (6 pp.) (1990, April)

In 1979 the U.S. Department of Energy (DOE) established the Remedial Action Program Information Center (RAPIC) at the Oak Ridge National Laboratory (ORNL) to provide technical information support to DOE's remedial action 
programs, which comprise: (1) Formerly Utilized Sites Remedial Action Program (FUSRAP), (2) Surplus Facilities Management Program (SFMP), and (3) Uranium Mill Tailings Remedial Action Program (UMTRAP). Specific information activities that RAPIC performs to support DOE's programs include: (a) maintaining a computerized bibliographic database containing approximately 700 ) annotated references relevant to remediation work at radioactively contaminated sites; (b) publishing an annual bibliography, Nuclear Facility Decommissioning and Site Remedial Actions, A Selected Bibliography, ORNL/EIS-154; (c) maintaining a document repository and providing copies of requested publications; and (d) performing manual and computerized searches of the technical literature. The most important RAPIC function is serving as a focal point for remedial action information. With these extensive resources at its command, RAi IC is in a unique position to provide a comprehensive information base to the remedial action and environmental restoration community.

351

Yu, C., Argonne National Laboratory, Argonne, IL

\section{Analysis of Radiological Survey Data to} Determine Contaminated Waste Volumes

Proceedings of the 29th Annual INMM Meet g, Las Vegas, NV, June 26- 29, 1988, Nuclear Materials Management, 959 pp.; (pp. 828-833) (1988)

A procedure was developed to analyze radiological survey data from a contaminated site to determine the volume of contaminated material that has to be cleaned up or removed before the site can be released for unrestricted use. This procedure was coded in a FORTRAN computer program, RADVOL. The survey data are analyzed statistically by averaging over an area of $10(0 \mathrm{sq} \mathrm{m}$ and a depth of $0.15 \mathrm{~m}$; the $\mathrm{K}$ sigma crror is used to calculate the net count rate, where $\mathrm{K}$ depends on the confidenec level required. The net count rates are converted to radionuclide concentrations and compared with the residual radioactive material guidelines to determine if the block (100 sq $\mathrm{m} \mathrm{X} 0.15 \mathrm{sq} \mathrm{m}$ volume) is contaminated above guidelines.

\section{2}

Yu, C., Y.C. Yuan, A.J. Zielen, and A. Wallo, Argonne National Laboratory, Argonne, IL; U.S. Department of Energy, Washing on, DC

\section{Residual Radioactive Material Guidelines: Methodology and Applications}

Report; 10 pp. (1989)

A methodology to calculate residual radioactive material guidelines was developed for the U.S. Department of Energy (DOE). This methodology is coded in a menu-driven computer program, R.ESRAD, which can be run on IBM or IBM-compatible microcomputers. Seven pathways of exposure are considered: external radiation, inhalation, and ingestion of plant foods, meat, milk, aquatic foods, and water. The RESRAD code has been applied to several DOE sites to calculate soil cleanup guidelines. This experience has shown that the computer code is easy to use and very user-friendly.

\section{3}

Ziegler, G.J., W.C. Services, Inc., Woodbury, NJ

\section{Remediation Through Groundwater Recovery Treatment}

Pollution Enginecring 21(7):75-79 (1989)

The costs associated with site cleanup activitics continuc to escalate. In most cases, these increases can be traced back to regulatory requirements pertaining to land disposal of materials. The following article proposes methods to collect the additional data necessary to sufficiently quantify and qualify the needs of the site remediation plan. Various metheds of site remediation are discussed with specific emphasis on the use of groundwater as a remediation technique. 


\section{$135 / 136$}

ENVIRONMENTAL RESTORATION PROGRAM 
354

Baes, C.F., and G. Marland, Oak Ridge National Laboratory, Oak Ridge, TN

Evaluation of Cleanup Levels for Remedial Action at CERCLA Sitcs Bascd on a Revicw of EPA Records of Decision

ORNL-6479; 51 pp. (1989, January)

The review revealed that the Record of Decision (ROD) is an imperfect instrument for examining the issue of how clean is clean. The expectation of finding clcanup goals in cach ROD was not fulfilled for at least four reasons. First, many sites are cleaned up in discrete steps or operable units; hence, a ROD may not cover the full remedy. Second, the technical feasibility of clcaning up a site is often unknown. In such cases, cleanup levels are defined after implementation of the remedy and not before. Third, the EPA often designs flexibility into the remedy selection process. In such cases, the ROD does not make a decision on waste treatment technology and, hence, the cleanup goal. Finally, some RODs are simply deficient, lacking clarity, pertinent text, or substantive information. This review makes it clear that most Superfund cleanup goals fall short of returning sites to a pristine condition. However, the EPA has been consistent in its remedy selection. Details may vary, but the gross features of remedies are largely consistent and predictable. Uniform standards are not achicved in each cleanup because most sites present complex and often unique cleanup problems. Remedies to reduce the toxicity, volume, or mobility of hazardous wastes without land disposal are expensive, technically difficult, and sometimes unavailable. As a result, the EPA opts for practical solutions and defends its actions with carefully crafted narratives intended to minimize regulatory, legal, and bureaucratic entanglements. Hence, "clean" becomes whatever can be done at a reasonable cost with the technology available, and which will be accepted by the public.

\section{5}

Burgher, B., M. Culpepper, and W. Zeiger, JRB Associates, McLean, VA

\section{Remedial Action Costing Procedures Manual}

EPA/60)/8-87/049; 56 pp. (1987, October)

This manual provides specific procedures for the cost estimating and economic analysis steps required for preparing engineering cost estimates for selecting remedial action alternatives in response to the requirements of the Comprehensive Environmental Response, Compensation, and Liability Act (CERCLA) and the National Contingency Plan (40 CFR 300). This manual is designed to be used in conjunction with EPA's manual entitled Guidance on Feasibility Studies Under CERCLA (1985). The audience for this manual includes EPA Regional Project Officers, remedial investigation/feasibility study contractors, and state and local remedial action personnel and other Federal agencies. Detailed procedures are provided for generating estimated capital and annual operating costs, calculating annual costs and present worth for each remedial action alternative, and performing sensitivity analyses of the cost estimates to determine the impact of changes to various cost input parameters. Worksheets are provided to assist the user in developing the feasibility cost analyses. An example cost analysis is provided to illustrate these procedures.

\section{6}

Conner, C.R., J. Yeasted, and M. Wilson, Westinghouse Materials Company of Ohio, Cincinnati, $\mathrm{OH}$

\section{CERCLA Removal Actions at DOE Facilities}

Proceedings of the 1989 Annual DOE Model Conference, Oak Ridge, TN, October 3-6, 1989, 54 pp.; (p. 13) (1989, October 3-6)

Removal Actions are being preformed at the Feed Materials Production Center near Fernald, Ohio. They are being initiated consistent with the "removal action" guidelines provided in the December 21, 1989, proposed revision to the National Oil and Hazardous Substances Pollution Contingency Plan (NCP). Pcrsonnel at the FMPC site are initiating substantial environmental cleanup activities as early as site data and information make it possible to do so. The initiation of a nontime critical removal action requires the preparation of an Enginecring Evaluation/Cost Analysis. This document provides a vehicle to obtain public input and, in the case of 
federal facilities, to obtain EPA concurrence for the proposed cleanup action. To help the reader to better understand the process being used, two types of removal actions are traced from their start to the present.

357

Coutant, C.C., and C.L. Heckman, Oak Ridge National Laboratory, Oak Ridge, TN

A Review of State Regulations that Exceed Those of the Federal Resource Conservation and Recovery Act (RCRA)

DOE/HWP-40; 187 pp. (1988, April)

This report identifies and provides information on state hazardous waste management programs and regulations in states where the US Department of Energy (DOE) has facilities. The objective is to describe for the DOE defense program and its contractors how state requirements are more stringent than the federal regulations under the Resource Conservation and Recovery Act (RCRA). DOE defense programs are located in 13 of the 50 states. Most of these states have regulations that are essentially equivalent to the federal RCRA requirements as they existed prior to the 1984 amendments, but their regulations are, in most instances, more stringment than the federal requirements. Differences are both substantive and procedural, and they are summarized and tabulated herein. All but three of these 13 states have been granted Final Authorization from the U.S. Environmental Protection Agency (EPA) to operate their own hazardous waste management program in accord with the federal RCRA program prior to the 1984 amendments; two of the three others have some stage of Interim Authorization. EPA currently administers all of the provisions of the 1984 amendments, including requirements for corrective action under Section 3004(u). Two states, Colorado and Tennessee, have been granted revisions to their Final Authorizations delegating responsibility for the hazardous wastes. Responsible state agencies (with appropriate telephone numbers) are indicated, as are the relevant laws and current regulatory statutes.

\section{8}

Cudworth, J.A., and J.D. Bauer, NUS Corporation, Aiken, SC; Analysas Corporation, Oak Ridge, TN

EPA (Environmental Protection Agency) and State Authority Over DOE (Department of Energy) Groundwater Radionuclides

CONF-881054 (Vol. 5); Proceedings of the 1988 Annual DOE Model Conference, Oak Ridge, TN, October 3-7, 1988, Vol. 5; (pp. 1563-1574) (1988)

This paper summarizes the extent of U.S. Environmental Protectioin Agency (EPA) and State authority to regulate radionuclides in the groundwater beneath U.s. Department of Energy (DOE) facilities. Radioactively contaminated groundwater is a potential problem for many DOE facilities, but the EPA and the States must establish legal authority before requiring remedial action or regulating discharges. While regulatory authority with respect to nonradioactive constituents has been clearly established, the same is not true for radioactive constituents. The question of facility radionuclide regulation entails issues such as sover ign immunity, Atomic Energy Act authority, the definition of federally permitted release, and the general lack of a Federal groundwater protection program. This paper addresses these issues through a review of statutes, court opinions, Congressional activities, EPA and State authority (for each state having a DOE operations office within its jurisdiction), and DOE field office experience. Experience at the DOE Savannah River Operations Office, Aiken, South Carolina, is highlighted.

359

Geffen, C.A., B.A. Garrett, C.E. Cowan, M.R. Siegel, and J.F. Keller, Pacific Northwest Laboratory, Richland, WA

Remediation of Hazardous Waste Sites: Planning and Integration Requirements

PNL-6972; 27 pp. (1989, Scptember)

Successful accomplishment of DOE environmental resioration program objectives will require 
consideration of regulatory and institutional constraints as well as technical issues. This report provides background information on the regulatory and institutional issues associated with the site characterization and assessment process, describes the site characterization and assessment activities that must be conducted before remediation can take place, indicates the magnitude of DOE's information management problem, identifies the nature of the information and data management problem associated with site cles?up, and recommends an approach for dealing with this issue. By establishing a technically credible information management system and applying it consistently across all sites, DOE could avoid many of the problems that have been encountered by EPA. Through advance planning, the expense of attempting to effect a uniform information management system after numerous, diverse systems have been put into place at the individual sites and by individual contractors within sites could be avoided.

\section{0}

Geffen, C.A., B.A. Garrett, and M.B. Walter, Pacific Northwest Laboratory, Richland, WA

Information Manag zment Systems for Integrating the Technical Data and Regulatory Requirements of Environmental Restoration Activitics

PNL-SA-17283; CONF-900210; Waste Managemerit '90: Working Towards a Cleaner Environment - Waste Processing, Transportation, Storage and Disposal, Technical Programs and Public Education, Proceedings of a Conference, Tucson, AZ, February 25-March 1, 1990; (11 pp.) (1990, March)

Current environmental regulations require that comprehensive planning be conducted before remediating a hazardous waste site to characterize the nature and extent of site contamination, calculate the risk to the public, and assess the effectiveness of various remediation technologies. Remediation of Department of Energy (DOE) sites contaminated with hazardous or mixed wastes will require the effective integration of scientific and engineering data with regulatory ani institutional requirements. The information management challenge presented by waste site cleanup activities goes beyond merely dealing with the large quantity of data that will be generated. The information must be stored, managed, and presented in a way that provides some consistency in approach across sites, avoids duplication of effort, and facilitates responses to requests for information from the regulators and the public. This paper provides background information on the regulatory requirements for data gathering and analysis for environmental restoration activities, and outlines the data and information management requirements for completing the preremediation phases of an environmental restoration project. Information management systems for integrating the regulatory and institutional requirements of the environmental restoration process with the technical data and analysis requirements are also described.

\section{1}

George, C.H. U.S. Department of Energy, Washington, DC

\section{The Department of Energy Program for Environmental Restoration}

CONF-880201; Waste Management '88: Waste Processing, Transportation, Storage and Disposal - Technical Programs and Public Education, Post, R.G. (ed.), Proceedings of a Conference, Tucson, AZ, February 26-March 3, 1988, Vol. 2, 1052 pp.; (pp. 149-151) (1988)

For more than forty years the U.S. Department of Energy (DOE) and its predecessor agencies have operated a vast industrial enterprise to produce nuclear materials and nuciear weapons for the national defense. Like other heavy industry world-wide, this industrial activity has managed and disposed of its wastes according to accepted practices that have later come to be questioned. Environmental laws and regulations have tightened the standards for hazardous substance control to reflect socicty's growing awareness of the persistence of many toxic substances in the environment and the need to protect land and environment for future use. As in the private industrial sector, DOE inherits a legacy of contaminated sites from its historical operations that must, under current law, at least be 
examined and considered for remedial action. The problem of cleaning up contamination at Defense Program sites has been described as a $\$ 20$ billion dollar effort spanning decades; while the real cost is unknown, the challenge is truly staggering. DOE's management burden will be increased by the large number of component tasks and milestones, by the stress of limited resources and noncompliance threats, by the intrusive oversight from multiple regulators, and by the need to constantly justify the program's demands to an infrastructure affiliated around weapons production.

\section{2}

Jump, R., U.S. Department of Energy, Oak Ridge Operations Office, Environmental Restoration Program, Oak Ridge, TN

Maraging the Startup of the Oak Ridge Operations Environmental Restoration Program

Proceedings of the 1989 Annual DOE Model Conference, Oak Ridge, TN, October 3-6, 1989, 54 pp.; (p. 25) (1989, October 3-6)

Between 1987 and 1989, the U.S. Department of Energy (DOE), Oak Ridge Operations Office (ORO) was developing programs to comply with RCRA requirements, the proposed DOE "CERCLA Order" and potential inclusion of ORO sites on the National Priority List (NPL), while assembling the organizational structure to manage their environmental restoration program. Budgets for this program have doubled every year from FY 1988 through FY 1990. Countless items such as the Interagency Agreement, Five-Year Plan, monthly reports, management plans, technology demonstrations, RCRA closures, Program Optimization System, and environmental audits were required. The environmental program at Oak Ridge cuts across a number of line organizations and is funded by several sponsors in DOE Headquarters which creates a matrix like a three dimensional chess board. This paper describes the management structure that was developed for both ORO and its contractors to manage this complex program. It also summarizes program activities planned for FY 1990-1995.
363

Keller, J.F., and C.A. Geffen, Pacific Northwest Laboratory, Richland, WA

Strategies for Environmental Restoration in an Evolving Regulatory Environment

PNL-SA-17282; CONF-900210; Waste Management '90: Working Towards a Cleaner Environment - Waste Processing, Transportation, Storage and Disposal, Technical Programs and Public Education, Proceedings of a Conference, Tucson, AZ, February 25-March 1, 1990; (11 pp.) (1990, March)

The U.S. Department of Energy (DOE) is faced with the immense challenge of effectively implementing a program to mitigate and manage the environmental impacts created by past and current operations at its facilities. Such a program must be developed and administered in accordance with the Comprehensive Environmental Response, Compensation and Liability Act, and the Resource Conservation and Recovery Act. These regulations are extremely complex, burdening the environmental restoration process with a number of planning and public interaction requirements that must be met before remediation of a site may begin. Existing regulatory and institutional requirements ior environmental restoration dictate that extensive planning, characterization, and assessment activities be conducted. An important part of the process is the involvement of regulators and the public in the site characterization and assessment activities and in developing reasonable solutions for cleanup. This paper identifies the regulatory requirements and highlights implementation strategies for key aspects of the environmental restoration process for DOE. Trends in legislation and policy relevant to the DOE environmental restoration process are highlighted, with strategies identified for dealing with the evolution of the regulations while maintaining continuity in the technical activities required for cleaning up the DOE hazardous and mixed waste sites.

364

Keller, J.F., and M.G. Woodruff, Pacific Northwest Laboratory, Richland, WA 
Applicable or Relevant and Appropriate Requirements (ARARs) for Radioactive Mixed Wastc

PNL-SA-16826; 14 pp.; CONF-891072; Multilevel Rescarch - Molecules To Man, Procecdings of the 27th Hanford Health and the Environment Symposium, Richland, WA, October 18-20, 1989 (1989, October)

Radioactive mixed waste (RMW) refers to waste containing both chemicals and radionuclides. Sites that contain such wastes are subject to a complex regulatory framework. Currently, no single statute or regulation addresses all aspects of RMW management and cleanup. This paper reviews the federal environmental pollution control and radioactive waste management statutes and regulations that may contain applicable or relevant and appropriate requirements (ARARs) as defined under the Comprehensive Environmental Response, Compensation, and Liability Act (CERCLA). Potential ARARs for the air, groundwater, surface water, soil, and overall exposure pathways are identified. Additional regulatory documents that contain potential standards are also identified. These requirements can be used in determining appropriate cleanup levels (or targets) for an RMW site.

\section{5}

Krueger, J.W., Los Alamos National Laboratory, Los Alamos, NM

Establishing a Regulatory Framework for a RCRA (Resource, Conservation, and Recovery Act) Corrective Action Program

LA-UR-89-643; CONF-890207; Waste Management '89, Proceedings of the 15th International Waste Conference, Tucson, AZ, February 26-March 2, 1989; (13 pp.) (1989)

Recently, the environmental community has become kecnly aware of problems associated with integration of the demanding regulations that apply to environmental restoration activities. One can not attend an EPA-sponsored conference on Superfund without distracting questions concerning the Resource, Conservation, and Recovery Act (RCRA) and the applicability of the National Contingency Plan (NCP) to sites that do not qualify for the National Priorities List (NPL). In particular, the U.S. Department of Energy (DOE) has been greatly criticized for its inability to define a comprehensive approach for cleaning up its hazardous waste sites. This article presents two decision flowcharts designed to resolve some of this confusion for DOE. The RCRA/CERCLA Integration Diagram can help the environmental manager determine which law applies and under what conditions, and the RCRA Corrective Action Decision Flowchart can guide the manager in detcrmining which specific sections of RCRA apply to a RCRA-lead environmental restoration program.

\section{6}

Kuo and Associates, McLean, VA

The Role of Sub-Surface Contaminant Fate and Transport Models for RCRA Land Ban Regulations

DOE/FE/60972-T1; 36 pp. (1988)

This report includes an overview of the requirements and complexity of ground water and solute fate and transport models, and considers the predictive value of existing models for both aquifers and unsaturated soils. The material is presented so as to be of practical value to OFE in understanding and commenting on models used by EPA in its rulcmakings and regulatory activities. Of specific interest is the EPACML model, which will be proposed later this year in the Federal Register. EPACML is EPA's new "back calculation model" (replacing EPASMOD) that will be used in the promulgation of RCRA land disposal regulations. The recommendations and conclusions are specifically intended to facilitate DOE comments in response to upcoming Federal Register announcements concerning EPACML and other relevant topics. The most important recommendations concern the need for EPACML to be employed on a site specific basis, and for EPA to demonstraic that the model has been field validated for a range of aquifer and solute types and conditions. 
367

Kurstedt, H.A., Jr., Virginia Polytechnic Institute and State University, Management Systems Laboratory, Blacksburg, VA

Programmatic Issues Affecting the Implementation of the DOE Five-Year Plan

CONF-900210; Waste Management '90: Working Towards a Cleaner Environment Waste Processing, Transportation, Storage and Disposal, Technical Programs and Public Education, Proceedings of a Conference, Tucson, AZ, February 25-March 1, 1990; (9 pp.) (1990)

Programmatic challenges the U.S. Department of Energy's Office of Environmental Restoration and Waste Management (EM) faces in the implementation of its five-year plan are identified and discussed. These challenges are characterized in the form of propositions and written specific challenges for these propositions. EM's situation in dealing with the propositions and related challenges is summarized. Specific make-or-break situations for EM are identified.

\section{8}

Lehr, J.C., Martin Marietta Energy Systems, Inc., Oak Ridge, TN; Analysas Corporation, Oak Ridge, TN

An Overview of the Department of Energy Defense Programs Environmental Restoration Program

CONF-881054 (Vol. 2); Proceedings of the 1988 Annual DOE Model Conference, Oak Ridge, TN, October 3-7, 1988; (pp. 369-373) (1988)

The U.S. Department of Energy (DOE) established the Environmental Restoration (ER) Program in 1987 to coordinate the remediation of Defense Programs (DP) inactive hazardous waste sites and to take corrective actions for any releases of hazardous wastes from any waste managemient unit meeting the definition of past disposal site. There are currently 16 DOE-DP installations involved in the ER program. Within these facilities more than 3500 release sites have been identified. The final draft of the ER Program Managemert Plan (PMP) was prepared in early 1988. The PMP develops the systems and procedures for management draft of the ER and Implementation Plan (PIP). A Program Optimization System (POS) has been developed to assist in making value judgments for allocation of programmatic funds beginning FY 1990. In the coming fiscal year, the PIP and PMP will be updated, with the emphasis on documentation requirements and the implementation of DOE Order 4700.1. While the program has made progress, it has not yet sufficiently matured to provide credible long-term cost estimates or schedule baselines.

\section{9}

Lehr, J.C., L.D. Eyman, and W.W. Jr. Thompson, Oak Ridge National Laboratory, Oak Ridge, TN

\section{Department of Energy Defense Programs Environmental Restoration Program Update}

CONF-890207; Waste Management '89, Proceedings of the 15th International Waste Conference, Tucson, AZ, February 26-March 2, 1989; (7 pp.) (1989)

Federal facilities are under increasing pressure to remediate inactive hazardous waste sites and associated off-site areas. The Superfund Amendments and Reauthorization Act federal facilities provision requires that the Environmental Protection Agency establish a public docket to list all federal sites contaminated by hazardous wastes or substances and to monitor the progress of investigations and cleanups against an established schedule. In addition, the Resource Conservation and Recovery Act requires that operating permits for hazardous waste treatment, storage, and disposal facilities be issued only upon binding agreements that identify specific schedules for corrective action for all hazardous waste releases that have or are occurring at the facility. Defense Programs (DP) must make remedial actions integral to its mission. Environmental cleanups are given increased emphasis with the new regulations/laws providing the right to private citizens and the states to sue to enforce these. statutes and schedule commitments. 
370

Middleman, L.I., U.S. Department of Energy, Washington, DC

\section{Environmental Restoration and Waste Management: Five-Year Plan, Fiscal Years 1992-1996}

DOE/S-0078P; 612 pp. (1990, June)

This document reflects the U.S. Department of Energy's (DOE's) fulfillment of a major commitment of the Environmental Restoration and Waste Management Five-Year Plan: reorganization to create an Office of Environmental Restoration and Waste Management (EM) responsible for the consolidated environmental management of nuclear-related facilities and sites formerly under the Assistant Secretaries for Defense Programs and Nuclear Energy and the Director of the Office of Encrgy Research. The purposes of this Plan for FY 1992-1996 are to measure progress in meeting DOE's compliance, cleanup, and waste management agenda; to incorporate a revised and condensed version of the Draft Research Development, Demonstration, Testing, and Evaluation (RDDT\&E) Plan (November 1989) to describe DOE's process for developing the new technologies critically needed to solve its environmental problems; to show DOE's current strategy and planned activities through FY 1996, including reasons for changes required to meet compliance and cleanup commitments; and 10 increase the involvement of other agencies and the public in DOE's planning.

371

Oak Ridge National Laboratory, Oak Ridge, TN

Proceedings of the Remedial Investigation/Fcasibility Study Workshop

DOE/HWP-72; ORNL/M-665; 2.34 pp.; CONF-8808110-Summ.; Procecedings of a HAZWRAP Workshop, Salt Lake City, UT, August 9, 1988 (1988)

The objective of this workshop was to familiarize U.S. Department of Energy (DOE) personnel and contractors with all aspects of developing, managing, and conducting a RI/FS, based on HAZWRAP SCO experience in similar activities as part of the Installation Restoration Program (IRP). The HAZWRAP SCO participation in U.S. Department of Defense (DOD) restoration activities provides an opportunity to develop capability and experience which are transferable to DOE activities. Paul Franco, Program Manager for the IRP, provided an overview of the IRP experience in conducting a RI/FS "or a National Priorities List (NPL) site and a noniNPL site. A nonNPL site does not require a RI/FS by regulation; however, the RI/FS process can be used to determine whether to proceed with a feasibility study or terminate the uction with a decision document. Al Porell, Program Manager for IRP, discussed the use of decision documents to remove nonNPL sites from regulatory consideration. DOF-Idaho has used similar documentation to remove numerous sites from their list of potential remedial action sites. Mr. Porell also discussed the use of the Technical Review Committee (TRC), which is established to coordinate activities during the RI/FS process. The TRC includes state, local, and federal authorities, and Air Force installation personncl.

\section{2}

Oak Ridge National Laboratory, Oak Ridge, TN

Proceedings of the U.S. Department of Energy Office of Environmental Restoration and Waste Management Waste Reduction Workshop

DCE/HWP-99; CONF-9002121; Proceedings of an U.S. Department of Energy, Office of Environmental Restoration and Waste Management Waste Reduction Workshop, Tampa, FL, February ö-7, 1990; (29 pp.) (1990), March)

The fourth of a series of waste minimization/reduction workshops was held at the Sheraton Grand Hotel in Tampa, Florida, on February 6-7, 1990. The workshops are held under the auspices of the Department of Energy's (DOE's) Office of Environmental Restoration and Waste Management. This workshop provided a forum for waste minimization/reduction planning, including waste minimization assessments. The workshops assist DOE waste-generating sites in implementing 
waste minimization/reduction programs, plans, and activities, thus providing for optimal waste reduction within the DOE complex. All wastes are considered within this discipline: liquid, solid, and airborne, within the categories of high-level (HLW), transuranic (TRU), low-level (LLW), hazardous, and mixed. Topics of discussion within workshops encompassed a wide range of subjects. Subjects included any method or technical activity from waste generation to disposal, such as process design or improvement, substitution of materials, waste segregation and recycling/reuse, waste treatment and processing, and administrative controls (procurement and waste awareness training). Consideration was also given to activities for remedial action and for decontamination and disposal.

373

Paducah Gaseous Diffusion Plant, Paducah, KY

Environmental Restoration and Waste Management Site Specific Plan for Oak Ridge Operation Office Paducah Gaseous Diffusion Plant

KY/H-104 (Rev. 1); 83 pp. (1990, July 18)

The Paducah Gaseous Diffusion Plant (PGDP) occupies 748 security-fenced acres located on a 3400-acre tract in McCracken County, Kentucky; it was previously part of the Kentucky Ordnance Works. The principle objective on-site process at PGDP is the separation of uranium isotopes through gaseous diffusion. The process produces enriched uranium, which is used for nuclear fuel in commercial power plants and for military purposes. This document provides an overview of the major environmental and waste management concerns at PGDP, requirements for implementation, organization/management, corrective activities, environmental restoration, waste management options, compliance with National Environmental Policy Act (NEPA), reporting and data management, quality assurance and federal, state, and local interactions.

\section{4}

Peach, J.D., U.S. General Accounting Office, Washington, DC

GAO's Views on DOE's Environmental Restoration and Waste Management Five-Year Plan

GAO/T-RCED-90-16; 12 pp. (1989, November 14)

This is the testimony of the Assistant Comptroller General for Resources, Community, and Economic Development of General Accounting Office (GAO) before the Committee on Governmental Affairs of the U.S. Senate. Mr. Peach's summary of his views: During the past year, the Congress has had the opportunity to view numerous plans to deal with U.S. Department of Energy's (DOE's) problems. The candid discussion of these plans is necessary if we, as a nation, are going to reach a consensus on an overall strategy and detailed implementation plan for correcting DOE's problems. The national consensus as well as DOE's plans are still developing. The five-year plan adds to the national debate. I believe its good points are the 30-year goal for achieving cleanup and a companion research and development plan for new technologies. However, I want to stress that DOE's problems are long-term and their resolution is far beyond the five-year projections contained in the plan. Further, while new technologies offer the promise of cost reductions, the technologies are not mature enough to be implemented now on a wide-scale basis to substantially reduce costs and ensure resolution of the problems. Today, we have a better inderstanding of the environmental problems facing the complex. However, DOE is still, to a large degree, in the study phase, and is continuing to develop information on the extent of these problems and their possible solutions. Although environmental solutions will be costly and difficult, specific long-range plans are important so that the Congress can judge the pace and direction of DOE's cleanup program.

\section{5}

Portsmouth Gaseous Diffusion Plant, Piketon, $\mathrm{OH}$ 
Long-Range Environmental and Waste Management Plan, Fiscal Years 1989-1995

POEF-2006; 423 pp. (1989, September)

This report, The Portsmouth Long-Range Environmental and Waste Management Plan, is the annual update in a scries begun at this installation in fiscal year 1985. The primary purpose of this report is to provide a thorough and systematic planning document to reflect the continuing process of site assessment, strategy development and planning for the current and long-term control of environmental issues, waste management practices, and remedial action requirements. The document also provides an estimate of the resources required to implement the current plan. This document is not intended to be a budget document but a tool to provide guidance to both Energy Systems and Department of Encrgy as to the order of magnitude of the resources (primarily funding requirements) and the time frame required to execute the strategy in the present revision of the plan. As with any document of this nature, the near-term (one to three years) part of the plan is a realistic assessment of the current program and ongoing capital projects and reflects the efforts perceived to be necessary to comply with all current state and federal regulations and DOE Orders. It also should be in generally good agreement with current budget (funding) requests and obligations for these immediate years. Beyond the immediate time frame, the document reflects the strategy and the project and funding estimates as a snapshot at the time of publication.

\section{6}

Richardson, B.S., S.M. Killough, M.D. Emery, J.N. Herndon, W.R. Hamel, and B.L. Burks, Oak Ridge National Laboratory, Oak Ridge, TN

Remote Site Survey and Characterization for the National Environmental Restoration and Waste Management (ERWM) Program Using the SRIP (Solider Robot Interface Project) Vehicle

CONF-900608; Procecdings of the 1990 Annual Amcrican Nuclear Society Mecting, Nashville, TN, June 10-14, 1990; (5 pp.) (1990)
A significant number of U.S. Department of Energy (DOE) production and research sites will require remediation of buried waste sites during the coming years. An important first step in cleanup, restoration, and decontamination activities is burial site characterization. An early field demonstration of buried waste site survey and characterization will be conducted using a remotely operated vehicle equipped with sensors, a manipulator system, and a vision system. This demonstration will be conducted in. July 1990.

\section{7}

Siegel, M.R., R.E. Gephart, P.L. Hendrickson, J.F. Keller, and W.K. Waller, Pacific Northwest Laboratory, Richland, WA

Comparative Revicw of U.S. Department of Energy CERCLA Federal Facility Agreements

PNL-7195; 42 pp. (1989, December)

The purpose of this report is to present a comparison of the three Federal Facility Agreements (FFAs) executed by the U.S. Department of Energy (DOE) and the U.S. Environmental Protection Agency (EPA). The report is intended to serve as a convenient reference guide for those responsible for drafting or reviewing future FFAs being considered by DOE. In addition, this report can provide the framework for the future analysis of completed FFAs and aid in the assessment of the relative merits of approaches and provisions used for different sites.

378

Taimi, K.I., U.S. Department of Energy, Assistant Secretary for Nuclear Energy, Office of Remedial Action and Waste Technology, Washington, DC

\section{Model Provisions for DOE Federal Facility Agreements}

CONF-8810239; Proceedings of the U.S. Department of Energy Remedial Action Plogram Annual Meeting, Gaithersburg, MD, October 18-20, 1988, 555 pp.; (pp. 1.7-1.20) (1988) 
Section 120 (e) of the Superfund Amendments and Reauthorization Act (SARA) requires that interagency agreements (IAG) be developed between the U.S. Environmental Protection Agency (EPA) and federal agencies that are the lead agencies in CERCLA cleanup actions. Over the past several years, the U.S. Department of Energy (DOE) has been negotiating with EPA and states to develop IAGs at various sites. The results of these negotiations have been consolidated in a model federal facility agreement (FFA), which goes beyond the SARA requirements. The model FFA addresses DOE cleanup actions from the investigation phase through remedial activities. It provides for state involvement in the decision-making process, integrates RCRA and CERCLA requirements, provides for stipulated penalties, and is enforceable. Negotiation of FFAs allows DOE, EPA, and the states to perform their roles in the remedial action process in an efficient and timely manner.

\section{9}

Turi, G.P., U.S. Department of Energy, Assistant Secretary for Nuclear Energy, Office of Remedial Action and Waste Technology, W'ashington, DC

\section{Status Report for the Working Group on Hazantous and Mixed Waste}

CONF-8810239; Proceedings of the U.S. Department of Energy Remedial Action Program Annual Meeting, Gaithersburg, MD, October 18-20, 1988, 555 pp.; (pp. 3.35-3.42) (1988)

The Hazardous and Mixed Waste Management Working Group was formed in December 1986 to provide for an increased exchange of experiences and issues among the U.S. Department of Energy (DOE) Nuclear Energy Remedial Action and Waste Technology Projects. The following focus was proposed for the Group: review hazardous and mixed waste requirements, standards, disposal options, experiences, problems/issues, solutions, liability insurance issues, RCRA/CERCLA compliance, reporting requirements, permitting requirements, etc. The working group has provided a forum for representatives from the remedial action projects to exchange information on hazardous and mixed waste management. Also, the representatives have gained a better understanding of the waste issues associated with each of the projects. The working group has fostered the transfer of information and experience for projects regulated under different programs and at different stages of development. This transfer provides a wider array of options with which individual projects may address future environmental compliance requirements.

\section{0}

U.S. Department of Energy, Office of Energy Research, Washington, DC

Site-Directed Subsurface Environmental Initiative: Five Year Summary and Plan for Fundamental Research in Subsoils and in Groundwater, FY 1989-FY 1993

$$
\text { DOE/ER-0364; } 54 \text { pp. (1988, April) }
$$

The initiative represents a commitment on the part of the Office of Energy Research to use national laboratory resources and specific university expertise to markedly advance the scientific and technological knowledge required to resolve critical environmental concerns. The mixed nuclear and chemical wastes generated by DOE operations contain chemicals common to wastes from most U.S. industries. Furthermore, the wastes share the potential for contamination of major US aquifers. This initiative will, therefore, provide information needed to resolve issues associated with waste disposal at the national level. The overall goal of this research initiative is to develop the necessary scientific basis for resolution of key technical obstacles to defining and remediating contamination at DOE and other waste sites. To accomplish this goal, the resources the national laboratories, universities, and DOE sites will be fully utilized to develop and demonstrate improved, cost-effective, and environmentally acceptable techniques for pre licting the behavior of contaminants and reducing their concentrations in groundwater. The document that follows is a preliminary plan to set general research directions for a program extending into the 199(s; detailed plans and priorities will come later. 


\section{1}

U.S. Department of Energy, Office of Energy Rescarch, Washington, DC

\section{Evaluation of Mid-to-Long Term Basic Rescarch for Environmental Restoration}

DOE/ER-0419; 68 pp. (1989, September)

This document describes a long-term basic research program for the U.S. Department of Encrgy (DOE) that complements departmental initiatives in waste management and site cleanup. The most important problems faced by DOE are environmental restoration of waste sites and cleanup of inactive facilities. Environmental restoration is defined in this report as characterization, assessment, remediation, and post-closure verification within the waste/environmental system at DOE sites. Remediation of inactive, contaminated waste-disposal sites is the largest and most expensive task lacing DOE. Immobilization, isolation, scparation, and destruction of waste, either above ground or in situ, are difficult and costly tasks. Technologies for these tasks are primitive or do not exist. Departmental problems in the long term are being analyzed scientifically and research needs are being identified. Basic research within DOE is directed toward fundamental knowledge leading to the discovery of new scientific or enginecring concepts and principals that may not have immediate specific technological applications.

\section{2}

U.S. Department of Energy, Office of Inspector General, Washington, DC

\section{Management Information Systems for Environmental Compliance Activities}

DOE/lG-()284; 20 pp. (1990), April 23)

The U.S. Department of Encrgy (DOE) is subject to federal and state laws designed to protect against threats to public health and the environment. The purpose of this audit was to determine whether DOE had developed adequate information systems for tracking and reporting on the status of its compliance with these laws. Systems used for prioritizing and budgeting for environmental activities are being addressed in a separate review.

\section{3}

U.S. Department of Energy, Richland Operations Office, Richland, WA

\section{The Hanford Reservation Environmental Restoration and Waste Management Five-Year Plan Activity Data Sheets}

DOE/RL-89-17; 495 pp. (1989, August)

During the preparation of a national 5-year plan covering environmental restoration and waste management activities for the Department of Energy (DOE) defense complex, detailed activity data sheets (ADSs) were prepared as field office input to DOE-Headquarters (DOE-HQ) for their use in developing the plan. This national plan is scheduled to be issued in August 1989. Before its issuance, a small group of key state and Indian nation representatives were involved in a review of the plan. At that time, the ficld office ADSs were available for a limited review. These ADSs, which present work scope and cost projections, are based on anticipated "needs" and are not considered a formal budget submittal. The sheets are broken into three categories: (1) waste management (WM), (2) environmental restoration (ER), and (3) corrective activities (CA). In turn, each of these categories is divided into four priority levels. The instructions following this introduction describe these four priority levels. Each field office is preparing a 5-ycar implementation plan in support of the DOE-HQ 5-year plan. Each of these implementation plans will be updated annually. These implementation plans will be developed with the benefit of reviews by affected states, Indian nations, and regulatory agencies.

\section{4}

U.S. Department of Energy, Richland Operations Office, Richland, WA; Westinghouse Hanford Company, Richland, WA

\section{Environmental Restoration Ficld Office Management Plan}




\section{DOE/RL-89-29; 83 pp. (1989, September)}

The primary purpose of the Hanford Reservation Environmental Restoration Remedial Actions (ERRA) Program is to support the U.S. Department of Energy, Richland Operations Office (DOE-RL) in bringing all known inactive hazardous sites (inactive after March 1, 1987) on the :-Tanford Reservation into compliance with applicable fr teral, state, and local environmental laws and regulations.

385

U.S. Department of Energy, Washington, DC

Environment, Salety, and Health Needs of the U.S. Department of Energy - Volume 2: Site Summaries

DOE/EH-0079 (Vol. 2); 297 pp. (1988)

This volume presents projections of environment, safety, and health activities and associated resources needed at individual U.S. Department of Energy (DOE) sites to maintain or, where required, to achieve compliance with applicable environmental, safety, and health requirements or to meet DOE objectives. The projections were developed from information provided by DOE Operations Offices, based on Environment, Safety, and Health Long-Range Plans developed by the sites in accordance with guidance from DOE Headquarters. This volume also contains projections of resource needs and activities for programs for which Headquarters has direct operational responsibility.

\section{6}

U.S. Department of Energy, Washington, DC

Environment, Safety and Health Report for the Department of Energy Defense Complex: Executive Summary

DOE/EH-8013171; 7 pp. (1988, July 1)

This environment, safety, and health (ESH) report for the U.S. Department of Energy's (DOE) defense complex provides a summary of current and projected activities and the associated resources that will be necessary to clean up environment contamination and to achicve and maintain compliance with ESH requirements. It reflects the best information estimates available as part of DOE's continuing process to address current requirements and problems.

387

U.S. Department of Energy, Washington, DC

Environment, Safety and Health Report for the Department of Energy Defense Complex

DOE/EH-8013172; 152 pp. (1988, July 1)

This environment, safety, and health (ESH) report highlights the policy, planning, and program activities that contribute to achieving and maintaining compliance with current ESH requirements. The report focuses on the U.S. Department of Energy (DOE) Defense Programs sites and their efforts to clean up environmental contamination and to assure and maintain compliance with ESH standards. Each DOE headquarters program office (Defense Progra:ns, Energy Research, Nuclear Energy, Fossil Energy, and Conservation and Renewable Energy being the major offices) is responsible for assuring that sites under their purview meet all Departmental requirements, including ESH standards. A DOE report will be issued in December 1988.

\section{8}

U.S. Department of Energy, Washington, DC

Environmental Restoration and Waste Managcinent - Five-Year Plan

DOE/S-0070; 447 pp. (1990)

This Plan covers the period through FY 1995. Its purpose is to establish a Department-wide agenda for cleanup and compliance against which overall progress can be measured. It encompasses three discretc compliance-related activity areas: (1) Corrective Activities, denoting activities necessary to bring active and standby facilities into compliance with local, state, and federal regulations; (2) Environmental Restoration, including the assessment and cleanup of surplus facilities and inactive sites; 
and (3) Waste Management Operations, concerned with the treatment, storage, and disposal of wastes generated as a result of ongoing operations at active facilitics. The Plan is structured in five sections. Section 1 is an Executive Summary setting DOE's agenda and establishing the course of action, including goals, planning premises, and new initiatives, plus a summary of proposed actions. Sections 2-4 provide information on planned activities in the three compliance-related areas, with specific information for each Operations Office and installation collected in the Attachments. Section 5 summarizes program-related Applied Research and Development, both planning initiatives and ongoing activities. The actions proposed in this plan constitute a sharp departure from DOE's traditional, unconsolidated approach to environmental restoration and waste management.

\section{9}

U.S. Department of Encrgy, Washington, DC

Applied Rescarch, Development, Demonstration, Testing and Evaluation Plan for Environmental Restoration and Waste Management

DOE/S-90010604 (Draft); 309 pp. (1989,
November) Nember)

This draft Department of Energy (DOE) Environmental Restoration and Waste Management Research, Development, Demonstration, Testing, and Evaluation (RDDT\&E) plan is the first of many annual documents to delineate the current state of restoration and minimization technologies and to set milestones for research to fulfill DOE's objectives of reduced risk to human health and the environment, decreased cost, and a 30-year restoration goal. This plan describes the initial makcup of the RDDT\&E program. The RDDT\&E program is necessary as part of the DOE commitment to (1) restore sites that have been impacted by mission activities related to weapons and encrgy research and (2) upgrade future DOE waste management operations. To illustrate the typical logic of the RDDT\&E program, remediation of the Hanford single-shell tanks (SST) is summarized and linked to elements of the Plan.
390

Walker, J.A., and L.I. Middleman, Virginia P. slytechnic Institute, Blacksburg, VA

Institutional Factors Affecting DOE Waste Management and Environmental Restoration Planning

CONF-900210; Waste Management '90: Working Towards a Cleaner Environment Waste Processing, Transportation, Storage and Disposal, Technical Programs and Public Education, Proceedings of a Conference, Tucson, AZ, February 25-March 1, 1990; (6 pp.) (1990)

The magnitude and impact of the U.S. Department of Energy's (DOE) environmental restoration and waste management program requires a drastic change in DOE's culture to include the participation of all levels of government, public forum representatives, and the public. Early in the process of developing a new, comprehensive 5-year plan for environmental restoration and waste management, Secretary Watkins invited affected states, Indian nations, and organizations of elected officials to form the State and Tribal Government Working Group to comment on two formulative drafts of the plan. Management Systems Laboratories of Virginia Tech was asked to help plan and facilitate two review sessions in the spring and summer of 1989 , based on perception of impartiality, experience with similar groups, and active affiliations with state governments. A third session in the fall was devoted to reviewing the draft applied $R \& D$ plan and guiding institutional factors affecting DOE's future: the need for ongoing, pervasive culture change; the need to display this change through truly cooperative planning; and the need to involve the regulatory community in the process of technology development so innovative solutions can be applied with the least possible delay.

391

Westinghouse Hanford Company, Richland, WA

Environmental Restoration Remedial Actions Program Ficld Oflice Work Plan 


\section{DOE/RL-88-40; 214 pp. (1989, February)}

The Environmental Restoration Remedial Actions (ERRA) Program was established by the U.S. Department of Energy, Defense Programs (DP) to comply with regulations for characterization and cleanup of inactive waste sites. The program specifically includes inactive site identification and characterization, technology development and demonstration, remedial design and cleanup action, and postclosure activities of inactive radioactive, chemically hazardous, and mixed waste sites. It does not include facility decontamination and decommissioning activities; these are included in a parallel program, Environmental Restoration Decontamination and Decommissioning (ERD\&D), also managed by DP. The ERRA program was formally established in FY 1988 at the Hanford Reservation to characterize and remediate inactive waste sites at Hanford. The objectives, planned implementation activities, and management planning for the ERRA program are contained in several planning documents. These documents include planning for the national program and for the Hanford program. This summary describes the major documents and the role and purpose of this field office work plan (FOWP) within the overall hierarchy of planning documents.

\section{2}

Westinghouse Hanford Company, Richland, WA

Fiscal Year 1989 Defense Waste Management and Enviroumental Program Plan

WHC-SP-0428; 200 pp. (1988, November)

The fiscal year (FY) 1989 Defense Waste Management and Environmental Program Plan provides a summary baseline for end function schedules, major milestones, budgets, and Work Breakdown Structure through FY-1995. The formal scope of this program has been revised to focus on key program elements. All schedule and budget information has been summarized in a fashion to help the reader better understand the program activitics, goals, and integration points. Detailed building block charts have been deleted to climinate confusion on program priorities. In addition to the baseline information, the Defense Waste
Management and Environmental Program's missions, objectives, strategies, and near-term work activities are described.

\section{3}

Whelan, G., K.E. Hartz, and N.D. Hilliard, Pacific Northwest Laboratory, Richland, WA; Beck and Associates, Seattle, WA

Remedial Action Assessment System (RAAS): Evaluation of Selected Feasibility Studies of CERCLA (Comprehensive Environmental Response, Compensation, and Liability Act) Hazardous Waste Sites

PNL-7229; 139 pp. (1990, April)

Congress and the public have mandated much closer scrutiny of the management of chemically hazardous and radioactive mixed wastes. Legislative language, regulatory intent, and prudent technical judgment call for using scientifically based studies to assess current conditions and to evaluate and select cost effective strategies for mitigating unacceptable situations. The NCP requires that a remedial investigation (RI) and a feasibility study (FS) be conducted at each site targeted for remedial response action. The goal of the RI is to obtain the site data needed so that the potential impacts on public health or welfare or on the environment can be evaluated and so that the remedial alternatives can be identified and selected. The goal of the FS is to identify and evaluate alternative remedial actions (including a no-action alternative) in terms of their cost, effectiveness, and engineering feasibility. The NCP also requires the analysis of impacts on public health and welfare and on the environment; this analysis is the endangerment assessment (EA). In summary, the RI, EA, and FS processes require assessment of the contamination at a site, of the potential impacts in public health or the environment from that contamination, and of alternative RAs that could address potential impacts to the environment.

394

White, A., and T. McKinley, Oak Ridge National Laboratory, Oak Ridge, TN 
Transferring Generic SARAVOSHA Training to U.S. Department of Energy Facilities

CONF-890470; Training of Nuclear Facility Personnel, Proceedings of a Symposium, Gutlinburg, TN, April 23, 1989; (pp. IV.B.5.1-IV.B.5.12) (1989, April)

The Tichnical Resources and Training Section staff at Oak Ridge National Laboratory (ORNL) have developed three extensive training programs for hazardous waste treatment, storage, and disposal facility workers as required by SARA/OSHA, 29 CFR 1910.120. The ORNL program is widely recognized as one of the best in the U.S, Department of Energy (DOE) system. ORNL and the Oak Ridge Associated Universities, who manages the Training Resources and Data Exchange (TRADE) network for DOE, entered into a cooperative relationship to respond to the many requests for DOE contractors for copies of the ORNL training materials. This discussion describes the ORNL program and the process of turning it into a series of generic tools which can be used by additional DOE facilities to meet the training requirements established by SARA/OSHA, 29 CFR 1910.120. The speakers describes how the materials are being used by DOE facilities as well as plans for additional resources to be developed through TRADE. 
$153 / 154$

AUTHOR INDEX 
Abe, T. 156

Adams, J.W. 226, 227

Adcl-Hadadi, M.A. 60

Adiga, R. 60

Afanas'ev, S.D. 50

Akimoto, H. 136

Alder, H.P. 217

Alder, J. 52

Alcksakhin, R.M. 329

Allen R.P. 1

Andersen, C.B. 53

Anderson, A.W. 54

Anttila, M. 55

Arendts, J.G. $\quad 231,232$

Arndt, H. 159

Asano, T. 193

Astall, M. 56

Atkin, R.G. 276

Austin, W.E 175

Bach, F.W. $\quad$ 57, 128, 233

Baes, C.F. 354

Bagryanskii, V.M. 160

Bailey, G. 58

Baliko, R. 59
Barkatt, A. 60,112

Barnes, S.M. 61

Basu, P.K 264

Bathcelor, A.J. 115

Baublitz, J.E 271, 299, 345

Bauer, J.D. 358

Becker, D.L 4

Beethe, R. 305

Bejarano, J.D. 325

Bejder, B.D. 62

Bell, M.J. 63

Benge, M.M. 5

Bentlcy, K.J. 218

Bergman, C. 64

Berven, B.A. 315

Beskid, NJ. 275, 276

Bettencourt, A.O. 294

Bishop, A. 65

Bixby, W.W. 176

Bizyacv, Y.S. 66

Blanke, J.A. 5

Boing, L.E 6,7

Boorman, T. 67,243

Borchardt, D. 59 
Borisch, R.R. 68

Bosnak, R. 69

Bostick, KA. 317

Bowen, W.W. 4

Bradbury, D. 70

Bramlitt, ET. 71

Brant, A.W. 72

Bresee, J.C. 345

Brighenti, G. 73

Britten, J.R. 295

Brosey, B. 92

Broughton, J.M. 96

Brown, G.A. 74

Brumfield, K $\quad 227$

Buck, S. 75

Buckley, D. 217

Budakov, A.A. 62

Bumpus, S.E 8

Burgess, D.M. 4

Burgher, B. 355

Burks, B.L 376

Butts, D. 151

Caldwell, J.A. 300

Camiscioni, B. 73
Capozzi, C. 151

Carl, D.E 68

Carricr, R.F. 281-283

Chapman, C.C. 61

Chapuis, A.M. 76,77

Charamathicu, M.A. 78

Chen, S.Y. 346

Chessa, G. 73

Cho, C.H. 192

Choi, W.K. 192

Chopra, O.K $\quad 9,36,38$

Chou, C.K. 49

Chung, H.M. 38, 79

Clark, R.L 336

Cliff, K.D. 295

Clifton, J.R. 80

Coleman, J.A. 301

Colquhoun, A. $\quad 75,81$

Conn, A.F. 84

Conner, C.R. 356

Conrath, A. 217

Constable, T.W. 326

Coons, L.M. 317

Coste, G. 10 
Cotten, P.R. 272, 273

Cotter, B.P. 85

Cottrell, W.D. 274

Coutant, C.C. 357

Cowan, C.E. 359

Cowan, S.P. 345

Crutcher, J.W. $\quad 277$, 281-283

Cudworth, J.A. 358

Culpepper, M. 355

Daily, M.C. 316

Dalzicl, S.P.C. 86

Damerow, M.W. 87

Danchenko, M.E. 88

Davis, B. 262

Davis, C.M. 177

Davis, J.P. 347

De Santis, A. 161

Delene, J.G. 90

Deutsch, WJ. 302

Devgun, J.S. 275,276

Dibobes, I.K 329

Dicrcks, D.R. 91

Dierks, R.D. 235

Dicwald, H. 135
Distenfeld, C.H. 92

Dixon, D.W. 295

Draulans, J. 93

Duerr, D. 11

Dwivedy, K.K. 334

Ebeling, W. 94, 95

Eidam, G.R. 96

Eidson, A.F. 327

Eisenstatt, LR. 97

Emery, M.D. 376

Enda, M. 117-119

Eremias, B. 100

Ericson, S.O. 296

Erikson, R.L. 303

Erramuspe, H.J. 101

Espegren, M.L. 315

Eyman, LD. 369

Faisca, M.C. 294

Feizollahi, F. 102-111

Feng, $\mathbf{X} \quad 60,112$

Fcraday, M.A. 113

Fernandez, F. 328

Figueroa, C.F. 328

Finger, S.M. $\quad 60,112$ 
Fingleton, D.J. 13

First, M.W. 166, 215

Fleischer, C.C. 114

Floyd, L.M. 278-283

Foley, R.D. 274, 277-283

Forde, M.C 115

Fraley, L. 318,335

Francioni, W. 217

Frecborn, W.P. 112,200

Fresl, M. 100

Freund, H.U. 114

Fritts, J. 319

Frost, C.R. 116

Fujita, R. 117-119

Fukuzawa, R. 120

Fultz, K.O. 121

Galecki, G. 174

Gardner, D.L 12

Gardner, P.H. 295

Garrett, B.A. $\quad 359,360$

Gee, E.F. 122

Geffen, C.A. $359,360,363$

Genova, M. 123

George, C.H. 361
Gcorge, J.L $\quad 344$

Georgi, B. 233

Gephart, R.E 377

Gerety, M. 284

Gerhard, M.A. 8

Gessner, R.F. 244

Gilbert, T.L. 285

Glover, W.A. $\quad 304,307$

Gocrty, R. 124

Golchert, N.W. 286

Goldmann, L.H. 4

Gomez, J.M.C. 328

Gonzales, D.E $\quad 305$

Gor'kov, L.V. 186

Gorai, T. 154

Gorup, F.F. 7

Gose, J.E. 235

Gouvras, G. 76

Grasso, C. 161

Green, S. 348

Gregory, A.R. 125

Grennhalgh, G. 126

Grinkevich, R.N. 50

Grobe, K. 128 
Guassardo, G. 127

Gulson, B.L. 329

Haferkamp, H. 128,129

Hagen, EW. 127

Haghighat, A. 130

Hamblin, C. 215

Hamel, W.R. 376

Hammermcister, D.P. 317

Hampill, H.G. 306

Harbecke, W. 252

Haroun, LA 13,14

Hartz, K.E 393

Hashish, M. 131, 132

Hatakeyama, M. 237

Haun, F.E 235

Hawrylewicz, B.M. 208

Hayle, J.C. 133

Hayward, D. 134

Heckman, C.L. 357

Heess, w. 217

Heine, W.F. 15,180

Hendrickson, P.L. 377

Hendry, L $\quad 330$

Henley, D.R. 7
Herndon, J.N. 376

Herrington, J. 316

Hess, W. 135

Hetzer, D.C. 214

Higuchi, S. 136

Hildebrand, J.E. 137

Hilliard, N.D. 393

Hirabayashi, T. 173

Hiraga, T. 120

Hlohowoskyj, I. 14

Hoffman, W.D. 138

Hoffmann, R. 139

Holahan, G.M. 140, 141

Holmes, R.G.G. 56

Holton, LK $\quad 153,235$

Hoopes, J.R. 307

Horan, J.T. 177

Horiguchi, J. 142

Hoshino, A. 237

Hostetler, C.J. 303

Hovingh, J. 8

Howard, C.G. 145

Huber, B. 146

Hudson, C.R. 90 
Hunt, R.A. 259

Ibrahim, S.A. 308

Igarashi, H. 92

Inada, E 191

Ishikawa, M. 149

Iso, S. 237

Jackson, G. 15

Jeffery, J.J. 331

Jenne, C. 150

Johnson, A.B. 1

Johnson, C.A. 274

Johnson, K.O. 313

Jolliffe, C.B. 145

Joseph, I. 151

Joya, I.E 21

Jump, R. 362

Jung, C.H. 192

Jusko, MJ. 285

Kamat, G.R. 152

Kamiyama, Y. 120

Kashiro, K. 193

Katayama, Y.B. $\quad 153,235$

Kawakami, M. 253

Kawasaki, M. 154
Kawasato, T. 120

Keefer, D.G. 177

Keller, J.F. $\quad 359,363,364,377$

Kemner, M.L 303

Kempf, C.R. 226, 227

Kennedy, W.E $\quad 155,187$

Keshian, B. 314

Killough, S.M. 376

Kim, H.P. 192

Kinzel, A. 128

Klockner, J. 59

Knab, L.I. 80

Knctl, G.J. 175

Kocher, D.C. 349

Kohno, N. 237

Kohout, R. 102-111

Kokaji, C. 156

Komatsu, F. 157

Komori, T. 237

Kondo, N. 120

Koop, W.N. 158

Korsch, M.J. 329

Kowalski, B.R. 262

Krauss, J.E 176 
Krohn, H. 59

Krueger, J.W. 365

Kruger, F.W. 159

Kuboschek, M. 128

Kurnosov, V.A. 160

Kurstedt, H.A. 367

LaGuardia, T.S. 16

Lambert, I. 161

Landau, B. 202

Landis, M.R. 17, 18, 287

Langner, G.H. $\quad 343,344$

Large, J.H. 162

Lasch, M. 163

Laverie, M. 164

Lawrence, B.E 298

Lawrence, R.E. 244

Lazo, E.N. 165

Le Duigou, A 161

Le Garreres, I. 166

Leap, D.R. $\quad$ 68, 176

Lechem, A.S. 208

Lec, D.J. 145

Lehr, J.C. $\quad 368,369$

Leidenberger, B. 139
Leigh, D.W. 167

Leske, D.N. 304

Levine, M.B. 40

Little, C.A. 315

Lo, T.Y. 19

Loercher, G. 168

Loeschhorn, U. 169-171

Longley, J. 316

Lorin, C. 172

Louie, R.L 20

Louis, H. 129

Lowson, R.T. 331

Lozano, J.C. 328

Luer, J. 59

Lukacs, G. 252

Luykx, F. 76, 77

MacDonnell, M.M. $\quad 13,14,21$

Macedo, P.B. 112,200

Mack, N. 128

Madruga, M.J. 294

Mahdy, M.A. $\quad 332,333$

Mantega, F. 123

Marland, G. 354

Martz, D.E. 343 
Masaki, N.M. 173

Mathur, A. 151

Mathur, A.K 334

Matsui, M. 253

Maxcy, M.L. 21

Mazarovich, E.O. 50

Mazurkiewicz, M. 174

McCardell, R.K. 96

McCusker, T.K 22

McGough, M.S. 175

McIntosh, T.W. 176

McIsaac, C.V. 177

McKinley, T. 394

McNamee, E.M. 288

McPherson, D. 151

Meier, G. 129

Meier, J.A. 23

Mellinger, G.B. 209

Metzler, D.R. 317

Michaille, P. 161

Middleman, LI. $\quad 370,390$

Milian, L.W. 227

Millard, J.B. 305

Miller, C.I. 178-180
Mincarini, M. 181

Miyo, H. 193

Mizon, K.J. 329

Moffett, D. 298

Mogg, C.S. 182

Moiscev, I.K. 160

Morcl, P. 205

Morillon, C. 183

Morisuc, T. $\quad 117-119$

Morris, R.C. 318,335

Mosavi, R.K 184

Mosho, G.D. 297

Movchan, S.V. 185

Wukhopadhyay, B. 319

Mulccy, P. 205

Muller, D.L. $3(02$

Murav'cv, V.F. 186

Murphy, R.O. 305

Napier, B.A. 187

Neider, R. 124

Nicmczyk, S.J. 188

Nilsson, I. 296

Nocy, K.C. 289-291

Noller, B.N. 329 
Novak, S. 194

Nyhan, J. 284

Obst, H. 190

Ogata, Y. 191

Oh, W.Z 192

Ohuchi, J. 191

Oliver, R. 284

Onuma, T. 136

Oshima, H. 193

Oura, S. 156

Owen, P.T. 350

Owens, D.E. 218

Ozolin, A.B. 186

Pachner, J. 194

Paine, D. 259

Parfitt, B.A. 219

Park, S.Y. 192

Pasqualetti, M.J. 195,196

Passant, F.H. 197

Pater, L.L. 198

Paustenbach, D.J. 34

Pavlik, O. 199

Peach, J.D. 374

Pearson, M.D. 342
Pegg, I.L. 112, 200

Peloquin, R.A. 155

Peterson, J.M. 13, 14, 21

Petrasch, P. 201

Petzhold, G. 135

Pezcimenti, D.M. 202

Philbin, J.S. 203

Pick, M.E. 204

Pickup, G. 336

Piepel, G.F. 209

Pilot, G. 57, 166, 172, 183

Poirier, J.C. 205

Pope, J.M. 61

Poupard, M. 161

Pourprix, M. 166

Pratapagiri, G. 206

Puchala, R.J. 208

Pye, L.D. 151

Rabold, H. 159

Radtke, S.A. 337

Rager, R.E 314

Rangel, M.J. 343

Redmon, M.E 293

Rcimus, M.A.H. 209 
Remark, J.F. 210

Reno, H.W. 218

Richardson, B.S. 376

Richardson, P.A.T. 295

Ricker, N.L. 262

Robertson, A. 300

Robertson, D.E $\quad 213,214$

Robertson, R.C. 276

Robinet, MJ. 297

Robinson, K.S. 215

Roger, J. 201

Rollstin, J. 203

Rood, A.S. 344

Rose, KW. 94, 95

Rosinski, S.T. $\quad 35,36$

Routier, J.F. 183

Routt, K.R. 97

Rouviere, R. 172

Rozhnov, V.S. 62

Ryabov, V.A. 329

Saad, EE 112

Sacki, M. 173

Saloio, J.H. 203

Sanchez, A.M. 325
Sanchez, A.R. 325

Sassoon, R.E. 112

Sato, M. 156

Schaller, K.H. 216

Schenker, E $\quad 135,217$

Schmied, H. 296

Schmitt, R.C. 218

Schork, J.S. 219

Schrciber, J.J. 37

Schwartzkopff, K $\quad 220$

Sehgal, J. 151

Sciki, Y. 222

Sckula, C.M. $\quad 289-291$

Shack, W.J. 9, 35, 36, 38

Shcil, A.E. 223

Shevchuk, I.M. 62

Shim, J.B. 192

Shulman, B. 39

Sicgcl, M.R. $\quad 359,377$

Sigmon, C.F. 40

Simon, S.L. 308

Sinclair, G. 331

Skupinski, F. 224

Snodgrass, W.J. 326 
Soo, P. 226, 227

Sousanpour, W. 60

Speer, D.R. 20

Stang, W. , 230, 252

Stanley, W.F. 5

Stcele, R. 231, 232

Steiner, H. 57, 233

Sterch, F. 59

Stolz, J.F. 234

Storz, W. 256

Stratton, W.R. 96

Strauch, G. 340

Surma, J.E. 235

Suwa, T. 154

Suzuki, A. 102-111

Suzuki, T. 237

Tachikawa, E 154

Tachon, M. 236

Taimi, K.I. 378

Takahashi, K. 222

Takeishi, H. 237

Tarasov, V.M. 66,238

Tarcza, J.E. 239

Tcixcira, M.M.G.R. 294
Thackston, J.W. 302

Theymann, W. 242

Thomas, C.W. 214

Thomas, P.J. 243

Thompson, W.W. 369

Tkachev, M.V. 62

Tolman, E.L. 96

Tome, F.V. 325

Tongway, D. 336

Trummer, DJ. 8

Trusov, A.G. 329

Tsubahara, T. 142

Tsunoda, N. 191

Tundo, D. 244

Turi, G.P. 379

Vandergaast, G. 298

Varley, J. 251

Vavasscur, C 205

Vcltkamp, D.J. 262

Vendel, J. 166

Vieno, T. 55

Vinikour, W.S. 292

Vinke, T. 128

Viticllo, T. 12.3 
Vlad, P.M. 202

Vollradt, J. 252

Wakui, H. 253

Waldron, P. 261

Walker, J.A. $\quad 390$

Waller, W.K. 377

Wallo, A. 285,352

Walter, M.B. 360

Wand, U. 340

Warner, R.F. 336

Wasastjerna, F. 55

Wasson, R.J. 336

Watzel, G.V.P. 255

Weick, J.M. 256

Wciss, A.J. 257

Wciss, S.H. 258

West, M.L. 259

Whelan, G. 393

Whicker, F.W. 308

Whitc, A. 394

White, J. 174

Whitehcad, W. 341
Williams, J. 260)

Williams, M.J. 293

Williams, M.S. 261

Wilson, M. 356

Windelberg, D. 233

Wirtu, K. 171

Wisc, B.M. 262

Witte, M.C. 8,49

Won, H.J. 192

Woodard, L.D. 263

Woodruff, M.G. 364

Woods, P.B. 264

Wynhoff, N.I_ 214

Yamada, Y. 142

Yamamoto, O. 253

Yanagihara, S. 149

Yasunaka, H. 154

Yeasted, J، 356

Yin, S.C.L. 292

Yonczawa, C. 237

Young, S. 265

Yu, C. $285,351,352$ 
$167 / 168$

Author Index

Yuan, Y.C. $285,346,352$

Zeiger, W. 355

Zicgler, G.J. 353
Ziclen, AJ. 285, 352

Zimmerman, G.P. 266 
CORPORATE AFFILIATION INDEX 
Akademie der Wissenschaften der DDR, Zentralinstitut fuer Isotopen- und Strahlenforschung, Leipzig, German Democratic Republic 340

Alfred University, New York State College of Ceramics, Alfred, NY 151

Analysas Corporation, Oak Ridge, TN 188, $304,358,368$

Ansaldo S.p.A., Genoa, Italy 127

Applied Radiological Control, Inc., Marietta, GA 210

Argonne National Laboratory, Argonne, IL $6,7,9,13,21,79,268-270,275,276,285$, $286,292,297,346,351,352$

Argonne National Laboratory, Environmental Assessment and Information Sciences Division, Argonne, IL 2, 3, 14

Argonne National Laboratory, Materials and Components Technology Division, Argonne, IL 91

Army Toxic and Hazardous Materials Agency, Aberdeen, MD 54

Atomic Energy Control Board, Ottawa, Ontario, Canada 194, 341

Australian Nuctear Science and Technology Organization, Lucas Heights, Australia 331

Ayrshire Radiation Monitoring, Fairlic, United Kingdom. 330

Bechtel Eastern Power Corporation, Three ilile: Island Nuclear Station, Middletown, PA 96

Bechtel National, Inc., Middletown, PA 92
Bechtel National, Inc., Oak Ridge, TN 5, 288-291, 293

Bechtel National, Inc., San Francisco, CA 269,2

Beck and Associates, Seattle, WA 393

Bhabha Atomic Research Centre, Bombay, India 152

Bradtec, Pencot, and Tresham, Wotton-Under-Edge, United Kingdom 70

Brenk Systemplanung, Aachen, Federal Republic of Germany 124

Briggs Technology, Inc., Pittsburgh, PA 198

British Broadcasting Corporation, London, United Kingdom 86

British Nuclear Fuels, Limited, Risley, United Kingdom 182

British Nuclcar Fuels, Limited, Scllafield, Cumbria, United Kingdom 56, 81, 223

Brookhaven National Laboratory, Upton, NY $165,214,227,257$

Building Research Establishment, Watford, United Kingdom 295

Bundesanstalt fuer Materialforschung und Prufung, Berlin, Federal Republic of Germany 124

Bundesministerium fuer Umwelt, Naturschutz und Reaktorsicherheit, Bonn, Federal Republic of Germany $163,168,169,190$, $216,220,230,255$

Catholic University of America, Vitreous State Laboratory, Washington, DC 60, 112, 200 
Central Electricity Generating Board, London, United Kingdom 74, 125, 197

Central Technical Rescarch Institute, Sato Kogyo Company, Limited, Japan 156

Centro Informazioni Studi Esperienze, Milan, Italy 123

Chem-Nuclear Environmental Services, Inc., Albuquerque, NM 305, 316, 319

Chiyoda Chemical Enginecring and Construction Company, Limited, Chiyoda, Japan 253

Chromalloy American Corporation, Orangeburg, NY 184

Colorado State University, Department of Radiology and Radiation Biology, Fort Collins, CO 308,318

Colorado State University, Fort Collins, CO 335

Comision Nacional de Energia Atomica, Buenos Aires, Argentina 101

Commissariat a l'Energic Atomique, Centre d'Etudes Nucleaires de Fontenay-aux.Roses, Institute de Protection et de Surete Nucleaire, Fontenay-aux-Roses, France 10, 76

Commissariat a l'Energic Atomique, Etablissement de la Vallec du Rhone, Bagnols-sur-Ceze, France 236

Commissariat a l'Energic Atomique, Paris, France 205

Commission of the European Communities, Brussels, Belgium 146, 224
Commission of the European Communities, Joint Development Center, Brussels, Belgium 82

Commission of the European Communities, Luxembourg, Luxembourg 83, 94, 95

Commonwealth Scientific and Industrial Rescarch Organisation, Division of Watcr Resourcas Rescarch, Canberra, Australia 336

Coopers and Lybrand, London, United Kingdom 150)

Cowal Monitoring Group, Dunoon, United Kingdom 330

CSIRO, North Ryde, Australia 329

Defense Nuclear Agency, Kirtland Air Force Bas:, NM 71

Department of Atomic Energy, Atomic Mincrals Division, Hyderabad, India 3.34

E.O. Paton Welding Institute, Kicv, Ukrainian SSR, USSR 88

ECOTEK, Inc., Erwin, TN 259

EG\&G Idaho, Inc., Idaho Falls, ID 22, 177, $218,231,232$

Egyptian Socicty of Nuclear Sciences and Applications, Cairo, Egypt 332, 333

Eldorado Resources, Limited, Ottawa, Ontario, Canada 298

Electrical Power Research Institute, Palo Alto, CA 98

Ente Nazionale per l'Energia Elettrica, Rome, Italy $73,123,181$ 
Environment Canada, Environmental Protcetion Service, Ottawa, Ontario, Canada 326

Extremadura University, Departmento de Fisica, Badajoz, Spain 325

Flow Industries, Inc., Kent, WA 131, 132

Gencral Electric Company, Hanford Atomic Products Operation, Richland, WA 158

General Physics Corporation, Columbia, MD 347

Gosudarstvennyj Komitet po Ispol'zovaniyu Atomnoj Ehnergii SSSR, Tsentral'nyj Nauchno-Issledovatel'skijInstitut Informatsii i, Moscow, USSR 62, 186

GPU Nuclcar Corporation, Middletown, PA 122,219

GPU Nuclear Corporation, Parsippany, NJ 137,175

Gull Associates, Washington, DC 188

Harvard University, Boston, MA 166, 215

Health and Safety Executive, London, United Kingdom 295

Hitachi Plant Enginecring and Construction Company Limited, Tokyo, Japan 136

House of Commons Energy Committee, London, England, United Kingdom 143, 144

Indescor Hydrodynamics, Inc., Concord, Ontario, Canada 208

Inhalation Toxicology Rescarch Institute, Albuquerque, NM 327
Institut de Protection et de Surete Nucleaire, Gif-Sur-Yvette, France 166

Intcrnational Atomic Energy Agency, Vienna, Austria 113, 147, 154, 194, 199, 204, 206

Jacobs Engincering Group, Inc., Albuquerque, NM $300,302,305,307,309-312$

Jacobs Engineering Group, Inc., St. Charles, MO 23-33, 348

Japan Atomic Energy Research Institute, Tokai Research Establishment, Department of Japan Power Demonstration Reactor, Tokai, Ibaraki, Japan 149, 173, 193, 222, 237

JRB Associales, McLcan, VA 355

Kernforschungzentrum Karlsruhe, Karlsruhe, Federal Republic of Germany 170, 171

Kernkraftwerke Cundremmingen Betriebsgesellschaft GmbH, Gundremmingen, Federal Republic of Germany 252

Kobe Stecl Limited, Kobe, Japan 157

Korca Advanced Encrgy Research Institute, Dacduk, Republic of Korea 192

Kraftwerk Emsland, Lingen, Federal Republic of Germany 252

Kuo and Associates, McLean, VA 366

Lawrence Livermore National Laboratory, Livermore, CA 8, 19, 49

LNETI, Department de Proteccao e Seguranca Radiology, Sacavem, Portugal 294

Los Alamos National Laboratory, Los Alamos, NM 284, 365 
Martin Marietta Energy Systems, Inc., Oak Ridge, TN 304,368

MK-Environmental Services, Inc., Grand Junction, CD 317

MK-Ferguson Company, St. Charles, MO 24-33

Morrison-Knudsen Engineers, Inc., Boise, ID 313

National Board for Atomic Safety and Radiation Protection, Berlin, German Democratic Republic 159

National Cooperative for the Storage of Radioactive Waste, Baden, Switzerland 52

National Institute of Radiation Protection, Stockholm, Sweden 64

National Institute of Standards and Technology, Gaithersburg, MD 80

National Radiological Protection Board, Chilton, United Kingdom 295

Nuclear Encrgy Agency, Paris, France 189

Nuklear-Ingenicur Service GmbH, Hanau, Federal Republic of Germany 252

NUS Corporation, Aiken, SC 358

Oak Ridge Associated Universities, Energy/Environment Systems Division, Oak Ridge, TN 272, 273

Oak Ridge Associated Universities, Manpower Education, Research, and Training Division, Oak Ridge, TN 17, 287

Oak Ridge Associated Universitics, Oak Ridge, TN 18
Oak Ridge National Laboratory, Energy Division, Oak Ridge, TN 266

Oak Ridge National Laboratory, Health and Safety Research Division, Grand Junction, CO 315

Oak Ridge National Laboratory, Health and Safety Rescarch Division, Oak Ridge, TN 277, 315

Oak Ridge National Laboratory, Oak Ridge, TN 40, 90, 274, 278-283, 349, 350, 354, $357,369,371,372,376,394$

Ontario Hydro, Toronto, Ontario, Canada 116

Pacific Northwest Laboratory, Richland, WA $1,61,153,155,187,209,214,235,236,303$, $359,360,363,364,377,393$

Paducah Gascous Diffusion Plant, Paducah, KY 373

PCI Energy Services, Lake Bluff, IL 175

Pennsylvania State University, University Park, PA 130

Portsmouth Gascous Diffusion Plant, Pikcton, OH 375

Power Reactor and Nuclear Fuel Development Corporation, Tokai, Ibaraki, Japan 191, 193

Research Association for Nuclcar Facility Decommissioning, Tokyo, Japan 212

Roy F. Weston, Inc., Albuquerque, NM 3(1)4, 314

Salamancia University, Laboratoric de Radiactividad Ambicntal, Salamacia, Spain 328 
Sandia National Laboratories, Albuquerque, NM 35, 36, 203

Science and Technology Agency, Nuclear Safety Bureau, Tokyo, Japan 221

Siemens AG, Offenbach, Federal Republic of Germany 59

Societe des Travaux en Milieu Ionisant, Gif-sur-Yvette, France 78

Societe des Travaux en Milicu Ionisant, Paris, France 225

Societe Francaise d'Encrgic Nucleairc, Paris, France 161

Statni Vyzkumny Ustav Ochrany Matcrialu G.V. Akimova, Praha, Czechoslovakia 100

Stuttgart University, Staatliche Materialpruefungsanstalt, Stuttgart, Federal Republic of Germany 9

Swedish Council for Building Rescarch, Stockholm, Sweden 296

Toda Construction Company Limited, Toda, Japan 120

Tokyo Electric Power Company, Tokyo, Japan 142

Toshiba Corporation, Kawasaki, Japan 118, 119

Toshiba Corporation, Nuclcar Engincering Laboratory, Kawasaki, Japan 117

Tracor Hydronautics, Inc., Laurcl, MD 84

Trumpf GmbH, Ditzingen, Federal Republic of Germany 256
U.S. Congress, House of Representatives, Committee on Ways and Means, Washington, DC 338

U.S. Department of Commerce, Maritime Administration, Washington, DC 245

U.S. Department of Energy, Albuquerque Operations Office, Uranium Mill Tailings Remedial Action Project Office, Albuquerque, NM $320-322$

U.S. Department of Energy, Assistant Sccretary for Nuclear Energy, Office of Remedial Action and Waste Technology, Washington, DC $54,306,323,378,379$

U.S. Department of Energy, Chicago Operations Office, Argonne, IL 7

U.S. Department of Energy, Division of Plans and Evaluation, Washington, DC 246

U.S. Department of Energy, Oak Ridge Operations Office, Environmental Restoration Program, Oak Ridge, TN 362

U.S. Department of Energy, Office of Energy Rescarch, Washington, DC 380, 381

U.S. Department of Energy, Office of Inspector General, Washington, DC 382

U.S. Department of Energy, Office of Remedial Action and Waste Technology, Washington, DC 324

U.S. Department of Energy, Richland Operations Office, Richland, WA 180, 383, 384

U.S. Department of Encrgy, Shippingport Station Decommissioning Project Office, Shippingport, PA 37

U.S. Department of Energy, Washington, DC $176,299,352,361,370,385-389$ 
U.S. Department of Encrgy, Weldon Spring Site Remedial Action Project Office, St. Charles, MO 41

U.S. Department of Energy, West Valley Demonstration Project Office, West Valley, NY 176

U.S. Environmental Protection Agency, Office of Emergency and Remedial Response, Washington, DC 42

U.S. General Accounting Office; Resources, Community, and Fconomic Development Division, Washington, DC 121

U.S. General Accounting Office, Washington, DC 374

U.S. Nuclear Regulatory Commission, Division of Enginecring, Washington, DC 38, 213, 226, 239

U.S. Nuclear Regulatory Commission, Division of Low-Level Waste Management and Decommissioning, Washington, DC 203, 247, 248

U.S. Nuclear Regulatory Commission, Oflice of Nuclear Regulatory Research, Washington, DC 166,214, 215, 249, 257

U.S. Nuclear Regulatory Commission, Washington, DC 250, 327

UNC Geotech, Inc., Grand Junction, CO 342

UNC Geotech, Inc., Technical Measurements Center, Grand Junction, CO 343, 344

United Kingdom Atomic Energy Authority, Atomic Energy Establishment, Chemistry Division, Winfrith, United Kingdom 145

United Kingdom Atomic Energy Authority, Harwell Laboratory, Harwell, United Kingdom $58,67,260$
United Kingdom Atomic Energy Authority, Northern Rescarch Laboratorics, Scascalc, United Kingdom 243

University of Bristol, Bristol, United Kingdom 261

University of Edinburgh, Edinburgh, Scotland 115

University of Hannover, Institut Werkstoffkunde, Welfengarten, Hannover, Federal Republic of Germany 233

University of Missouri at Rolla, Rolla, MO 174

University of Washington, Center for Process Analytical Chcmistry, Scattle, WA 262

Verein Deutscher Ingenicure (VDI) Gescllschaft Energictechnik, Duesseldorf Federal Republic of Germany 242

Vereinigte Elektrizitactswerke Westfalen AG, Dortmund, Federal Republic of Germany 252

Virginia Polytechnic Institute and State University, Management Systems Laboratory, Blacksburg, VA 367

Virginia Polytechnic Institute, Blacksburg, VA 390

Voimayhtiociden Ydinjactetoimikunta, Hclsinki, Finland 55

W.C. Services, Inc., Woxdbury, NJ 353

Wastechem, Bramhall, United Kingdom 72

West Valley Nuclear Services Company, Inc., West Valkey, NY $61,68,87,97,138,176$, 202, 244 
Westinghouse Hanford Company, Richland, WA $4,12,15,20,180,384,391,392$

Westinghouse Hanford Company, Shippingport Station Decommissioning Project Office, Shippingport, PA 44-48
Westinghouse Materials Company of Ohio, Cincinnati, OH 356 
$179 / 180$

TITLE WORD INDEX 


\section{Abandoned}

Radionuclides in an Abandoned Reactor Facility 158

Abrasive

Radium and Heavy Metal Transport Beneath an Abandoned Uranium Tailings Dam 331

Submerged Cutting of Steel by Abrasive Water Jets 129

Cutting with Abrasive Waterjets 131

Abrasives

Cutting with Abrasive Waterjets 132 Accident

Adaption of High-Pressure Water Jets and Abrasives to Dismantle Nuclear Installations 172

GPU Nuclear Corporation: Availability oi Final Supplement 3 to the Programmatic

Environmental Impact Statement Related to Decontamination and Disposal of Wastes from March 28, 1979 Accident Three Mile Island Nuclear Station, Unit 2234

\section{Accountancy}

Effectiveness of Cleanup Criteria Relative to an Accident Nuclear Release 346

Acid

The Curious Accountancy of Decommissioning 240

Hydrochloric Acid Leaching of Uranium, Thorium, Radium and Rare-Earth Elements, from an Elliot Lake Radioactive Ore 333

Act

A Review of State Regulations that Exceed Those of the Federal Resource Conservation and Recovery Act (RCRA) 357

Establishing a Regulatory Framework for a RCRA (Resource, Conservation, and Recovery Act) Corrective Action Program 365

Remedial Action Assessment System (RAAS): Evaluation of Selected Feasibility Studies of CERCLA (Comprehensive Environmental Response, Compensation, and Liability Act)

Activated Hazardous Waste Sites 393

Activity Inventory of the Activated Decommissioning Waste of the Loviisa Nucle 6 Power Plant 55

Adaption

Activated Concrete Cutting Machine (Reactor Decommissioning) 222

Administration

Adaption of High-Pressure Water Jets and Abrasives to Dismantle Nuclear Installations 172

Appendix A to Facility License No. NS-1 Technical Specifications and Bases (Issued as Change No. 10) for the N.S. Savannah Reactor Maritime Administration U.S. Department of Commerce, Amendment No. 7245

Advisory Acrosol

Meeting of the Advisory Panel for the Three Mile Island, Unit 2133

Aerosol Generation During Cutting of Various Materials with Plasma, Laser and Consumable Electrode 233

\section{Acrosols}

Ventilation and Filtration Techniques for Handling Aerosols Produced by Thermal Cutting Operations 65

Study and Optimization of Filter Systems for Separating Dusts and Acrosols Produced in Layers Concrete Decontamination 95

Measurement and Removal of Steel Flame Cutting Acrosols (0.01-1 um) in WAGR Decommissioning Cleaning Laboratory 215 
Aged

Seismic Research on an Aged United States Gate Valve and on a Piping System in the Decommissioned Heissdampfreaktor (HDR): Summary 231

Seismic Research on an Aged United States Gate Valve and on a Piping System in the Decommissioned Heissdampfreaktor (HDR): Appendices 232

Agency

International Atomic Energy Agency's Program on Decontamination and Decommissioning 113

EPA (Environmental Protection Agency) and State Authority Over DOE (Department of Energy) Groundwater Radionuclides 358

Aging

Shippingport Station Aging Evaluation 1

Aging Studies on Materials from the Shippingport Reactor 38

Thermal Aging of Some Decommissioned Keactor Components and Methodology for Life Prediction 79

Effect of Decontamination on Aging Processes and Considerations for Life Extension 91

Proposed IAEA Programme on Safety Aspects of Nuclear Power Plant Aging and Life Extension 194

\section{Apreements}

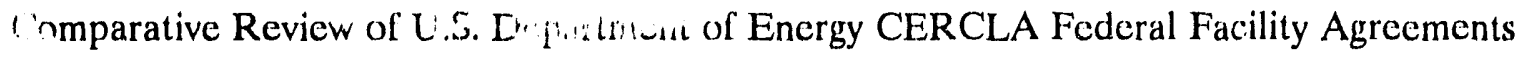
377

AGRs

Model Provisions for DOE Federal Facility Agreements 378

Agueda

AliRs - The Reckoning 51

Linpact of Uranium Mining on the Radioactive Contamination of the Agueda River 328

Air

Installation for Semiautomatic Air-Plasma Metal Cutting Up to $6 \mathrm{~mm}$ Thickness 62

A Look at Air-PAC Machines (Plasma Arc Cutting) 263

Albany

Certification of the Radiological Condition of Thirty-Five Private Properties Located in Colonie and Albany, NY 271

Alloys

Mechanism of Corrosion in Decontaminating Solutions of Stainless Steel and Highly Wear Resistant Hardfacing Alloys for a Liquid Metal Fast Breeder Reactor 100

Alpha

Experience in the Decontamination and Dismantling of Alpha Facilities 78

Dismantling of an Alpha Contaminated Hot Cell at the Marcoule Pilot Plant 236

\section{Analysis}

Calibration of Alpha-Track Monitors for Measurements of Thoron 342

Model Testing Conducted to Benchmark the Shippingport Reactor Pressure Vessel/Neutron

Shield Tank Safety Analysis Report for Packaging 4

Benchmarking of the Computer Code and the Thirty-Foot Side Drop Analysis for the Shippingport RPV/NST Package 8

Engineering Evaluation/Cost Analysis for the Proposed Management of Contaminated Water Impounded at the Weldon Spring Chemical Plant Area 21

Shippingport Neutron Shield Tank Sampling and Analysis Program 35 
Analysis

Analysis of Results Obtained with Different Cutting Techniques and Associated Filtration Systems for the Dismantling of Radioactive Metallic Components 57

Decontamination and Decommissioning, License Renewal, Human Factors, Generic Issues,

Risk Analysis/PRA Applications, Innovative Concepts for Increased Safety of Advanced Power Reactors 257

Principal Components Analysis for Monitoring the West Valley Liquid Fed Ceramic Melter 262

Enginecring Evaluation/Cost Analysis for the Proposed Removal of Contaminated Materials from Pad 1 at the Elza Gate Site, Oak Ridge, Tennessec 268

Analysis of Radiological Survey Data to Determine Contaminated Waste Volumes 351

Annotation

Uranium Mill Tailings: Annotation of Land Records 299

Uranium Mill Tailings: Annotation of Land Records 301

Applicabilitics

Study Into the Applicabilities of Lasers for the Dismantling of Decommissioned Nuclear Power Plant 128

Applicable

Applicable or Relevant and Appropriate Requirements (ARARs) for Radioactive Mixed Waste 364

Approaches

Main Approaches to NPP Decommissioning and to the Radioactive Waste Problem to be Solved in France 66

ARARs

Applicable or Relevant and Appropriate Requirements (ARARs) for Radioactive Mixed Waste 364

Arc

Underwater Arc Cutting with a Cored Electrode 88

Dismantling of JPDR Internals Gets Under Way Using Plasma Arc Cutting 149

Underwater Plasma Arc Cutting in Three Mile Island's Reactor 175

Contact Arc Cutting of Worked-Out Equipment 186

A Look at Air-PAC Machines (Plasma Arc Cutting) 263

30 Years of Experience with Arc Plasma Metal Cutting 267

Architects

Radon Control and Remedies in Buildings Cornwall County Council, County Architects Department, Truro, United Kingdom 295

Argonne

Project Plan for the Decontamination and Decommissioning of the Argonne National Laboratory Experimental Boiling Water Reactor 6

Arizona

Environmental Assessment of Remedial Action at the Monument Valley Uranium Mill Tailings Site, Monument Valley, Arizona 320

Army

Department of the Army Installation Restoration Program 54

Ash

Assessment of Ash Pond Isolation Project Effectiveness 33 
Asscmbly

Radionuclide Characterization of Reactor Decommissioning Waste and Spent Fuel Assembly Hardware 214

Assessment

Multimedia Assessment of Health Risks for the Weldon Spring Site Remedial Action Project 13

Phase 2 Groundwater Quality Assessment for the Weldon Spring Site, Chemical Plant, Raffinate Pits and Surrounding Vicinity Properties 28

Assessment of Ash Pond Isolation Project Effectiveness 33

The Risk Assessment of Environmental and Human Hazards 34

Environmental Compliance Assessment Findings for Weldon Spring Site Remedial Action Program 40

Envirormental Assessment and Finding of No Significant Impact Regarding Proposed Order Authorizing Dismantling of the Reactor and Decomposition of Component Parts: Michigan State University 178

Environmental Assessment and Finding of No Significant Impact Regarding Proposed Order Authorizing Phase 2 Dismantling of the Reactor and Disposition of Component Parts: The University of California at Los Angeles 179

Environmental Assessment and Finding of No Significant Impact Regarding Proposed Order Authorizing Dismantling of the Reactor and Decomposition of Component Parts 258

Work Plan for the Remedial Investigation/Feasibility Study - Environmental Assessment for the Colonie Site, Colonie, New York 270

Environmental Assessment of Remedial Action at the Monument Valley Uranium Mill Tailings Site, Monument Valley, Arizona 320

Remedial Action Assessment System (RAAS): Evaluation of Sclected Feasibility Studies of CERCLA (Comprehensive Environmental Response, Compensation, and Liability Act) Hazardous Waste Sites 393

\section{Assessments} Assurance

Radionuclide Source Term Measurements for Decommissioning Assessments 213

Materials Licensee Financial Assurance Guidance Related to Decommissioning: Availability 63

Standard Format and Content Guide for Financial Assurance Mechanisms Required for Decommissioning Under 10 CFR parts 30, 40, 70, and 72 - Revision 1247

Standard Review Plan for the Review of Financial Assurance Mechanisms for

Decommissioning Under 10 CFR Parts 30, 40, 70, and 72 - Revision 1248

Audits

Graphical Quality Assurance and Data Management on the UMTRA Project 316

Authority

Radiological Surveillances and Health and Safety Audits at UMTRA Sites 305

Decommissioning Nuclear Power Plants: Authority and Policy Issues 64

Licensing Authority Experience and Policy for Decommissioning of Nuclear Installations 164

Decommissioning in the United Kingdom Atomic Energy Authority 260

EPA (Environmental Protection Agency) and State Authority Over DOE (Department of Energy) Groundwater Radionuclides 358 
Authorizing

Michigan State University TRIGA Nuclear Reactor: Order Authorizing Dismantlement of Facility and Disposition of Component Parts 140

The University of California, Berkeley: Order Authorizing Dismantling of Facility and Disposition of Component Parts 141

Environmental Assessment and Finding of No Significant Impact Regarding Proposed Order Authorizing Dismantling of the Reactor and Decomposition of Component Parts: Michigan State University 178

Environrnental Assessment and Finding of No Significant Impact Regarding Proposed Order Authorizing Phase 2 Dismantling of the Reactor and Disposition of Component Parts: The University of California at Los Arigeles . 179

Environmental Assessment and Finding of No Significant Impact Regarding Proposed Order Authorizing Dismantling of the Reactor and Decomposition of Component Parts 258

Average

Variation in the Annual Average Radon Concentration Measured in Homes in Mesa County, Colorado 344

\section{Bagless}

Development of Bagless Transfer Systems at British Nuclear Fuels Limited (BNFL) 56

\section{Baltimore}

Results of the Indoor Radiological Survey at the W.R. Grace Company, Curtis Bay Site, Baltimore, Maryland 274

Ban

The Role of Sub-Surface Contaminant Fate and Transport Models for RCRA Land Ban Regulations 366

Bank

The Decommissioning Data Bank (DDB) - Methodology and Applications 201

Barrows

Volume Estimate of Radium-Contaminated Soil in a Section of Barrows Field Park, Glen

Bascline Ridge, New Jersey, November-December 1989297

Baseline Risk Evaluation for Exposure to Bulk Wastes at the Weldon Spring Quarry, Weldon Spring, Missouri 14

Bases

Appendix A to Facility License No. NS-1 Technical Specifications and Bases (Issued as Change No. 10) for the N.S. Savannah Reactor Maritime Administration U.S. Department of Commerce, Amendment No. 7245

Bed Bchavior

Development of Rock Bed Boring Machine Using Ultra-High Pressure Water 142

Crystallization Behavior of a Fully Simulated West Valley Borosilicate Glass 151

Benchmark

Model Testing Conducted to Benchmark the Shippingport Reactor Pressure Vessel/Neutron Benchmarking

Shicld Tank Safety Analysis Report for Packaging 4

Benchmarking of the Computer Code and the Thirty-Foot Side Drop Analysis for the Shippingport RPV/NST Package 8 
BER

Berkeley

BER II - Dismantling and Conditioning 59

Starting to Dismantle Berkeley (Reactor Decommissioning) $\mathbf{7 4}$

The University of California, Berkeley: Order Authorizing Dismantling of Facility and Disposition of Component Parts 141

Long Goodbye - Why it Will Take 100 Years to Demolish This (Berkeley) Nuclear Power Station 265

Beta

Biogenic

Gamma and Beta Logging of Underground Sewer and Process Lines 343

Biological

Biogenic Approach to the Treatment of Uranium Mill Effluents 334

Research and Development of a Machine for the Removing System of Biological Shield Wall of a Nuclear Reactor 120

Determination of the Long-Lived Nuclides in Biological Shiclding Concrete, Ion Exchange Resin and Fuel Storage Pool Water of JPDR 237

Biological Characterization of Radiation Exposure and Dose Estimates for Inhaled Uranium

\section{Blowdown} Milling Effluents 327

BNFL

The Blowdown Water Cannon - A Novel Method for Powering the Cumulation Nozzle 198

Boiling

Development of Bagless Transfer Systems at British Nuclear Fuels Limited (BNFL) 56

Project Plan for the Decontamination and Decommissioning of the Argonne National Laboratory Experimental Boiling Water Reactor 6

Status of the Decontamination and Decommissioning of the Experimental Boiling Water

Boring Reactor (EBWR) 7

Borosilicate

Development of Rock Bed Boring Machine Using Ultra-High Pressure Water 142

Crystallization Behavior of a Fully Simulated West Valley Borosilicate Glass 151

Box

The Decommissioning of Large and Complex Glove Box Structures in a Mixed Oxide Fuel

Fabrication Plant 93

Branch

Decommissioning of Pu Contaminated Glove Box System 193

Compilation of Contract Research for the Materials Enginecring Branch, Division of

\section{Breakdown} Engineering 250

\section{Breeder}

Mechanical Dismantling and Breakdown Methods 190

Mechanism of Corrosion in Decontaminating Solutions of Stainless Steel and Highly Wear Bricks

Resistant Hardfacing Alloys for a Liquid Metal Fast Breeder Reactor 100

Conditioning of Graphite Bricks from Dismantled Gas Cooled Reactors for Disposal 109 


\section{Britain}

Introducing the Geosocial Context of Nuclear Decommissioning - Policy Implications in the US and Great Britain 195

British

Development of Bagless Transfer Systems at British Nuclear Fuels Limited (BNFL) 56

Decommissioning in British Nuclear Fuels PLC 81

\section{Building}

Sampling Plan for the Unconditional Release of Building Materials and Similar Large

ir monents Encountered a Decommissioning 12

Ev: un of Contamination on Concrete of JPDR Building 103

324 aks 325 Building Hot Cell Cleanout Program - Decontamination of C-Cell 153

The TMI-2 (Three Mile Island Unit 2) Reactor Building Gross Decontamination Experiment - Effects on Loose-Surface Contamination Levels 165

Btrildings

Buildings Radiological Characterization Report for the Weldon Spring Site Remedial Action Project, Weldon Spring, Missouri 31

Radin Control and Remedies in Buildings Cornwall County Council, County Architects Department, Truro, United Kingdom 295

Radon I Dwellings - Testing and Evaluation of Constructional and Buildings Services Engineering Measures 296

Built

\section{Calibration}

Nuclear Reactors 3uilt, Being Built, or Planned - 1989246

\section{California}

Calibration of Alpha-Track Monitors for Measurements of Thoron 342

The University of California, Berkeley: Order Authorizing Dismantling of Facility and Disposition of Component Parts 141

Environmental Assessment and Finding of No Significant Impact Regarding Proposed Order Authorizing Phase 2 Dismantling of the Reactor and Disposition of Component Parts:

Canada The University of California at Los Angeles 179

Canadian

Decommissioning Waste Management in Canada 106

Decommissioning of uranium Mines and Mills - Canadian Regulatory Approach and Experience 341

Cannon

The Blowdown Water Cannon - A Novel Method for Powering the Cumulation Nozzle 198 Cap

Effects of Vegetation, A Clar Cap and Environmental Variables on Rn-222 Flu ce Rate from Reclaimed Uranium Mill Tailings 335

Carbide

Remedial Actions at the Forriver Union Carbide Corporation U ium Mill Sites, Rifle, Garfield County, Colorado - Final Environmental Impact? "ent, Volume I: Text 321

Remedial Actions at the Form : Union Carbide Corporation Uranium Mill Sites, Rifle, Garficld County, Colorado - Final Environmental Impact Statement, Volıme II: Appendices 322 


\section{Cavisating \\ Rapid Cutting of Pavement with Cavitating Water Jets 84}

Cell

324 and 325 Building Hot Cell Cleanout Program - Decontamination of C-Cell 153

Dismantling of an Alpha Contaminated Hot C.dl at the Marcoule Pilot Plant 236

Cells

Cement

Cleanout and Decontamination of Radiochemical Hot Cells 235

Immobilization in Cernent of Ion Exchange Resins Arising from the Purification of Reagents Used for the Decontamination of Reactor Circuits - Fifth Semestrial Report July-December 1988145

Ceramic

Principal Components Analysis for Monitoring the West Valley Liquid Fed Ceramic Melter 262

CERCLA

Implementation of an Integrated CERCLA-NEPA Environmental Process at a FUSRAP Site 276

Evaluation of Cleanup Levels for Remedial Action at CERCLA Sites Based on a Review of EPA Records of Decision 354

CERCLA Removal Actions at DOE Facilities 356

Comparative Review of U.S. Department of Energy CERCLA Federal Facility Agreements 377

Remedial Action Assessment System (RAAS): Evaluation of Selected Feasibility Studies of CERCLA (Comprehensive Environmental Response, Compensation, and Liability Act)

Certification Hazardous Waste Sites 393

Certification of the Radiological Condition of Thirty-Five Private Properties Located in Colonie and Albany, NY 271

CFR

Radionuclide Correlations at TMI-2 for 10 CFR 61 Compliance 98

Standard Format and Content Guide for Financial Assurance Mechanisms Required for Decommissioning Under 10 CFR parts 3C, 40, 70, and 72 - Revision 1247

Standard Review Plan for the Review of Financial Assurance Mechanisms for Decommissioning Under 10 CFR Parts 30, 40, 70, and 72 - Revision 1248

Standard Format and Content for Decommissioning Plans for Licensees Under 10 CFR Parts 30,40 , and 70249

\section{Chairman}

Nuclear Regulation: NRC's Decommissioning Procedures and Criteria Need to Bc Strengthened - Report to the Chairman, Environment, inergy, and Natural Resources

Chambers Subcommittee, Committee on Government Operations, House of Representatives 121

Snippingport Station Decommissioning Project: Removal of Structures and Containment Changed Chambers - Topical Report $\mathbf{4 6}$

The Rules Changed 304

Characterization

Characterization of Preferred Groundwater Migration Pathways Weldon Spring Site 23 


\section{Characterization}

Radiological and Chemical Characterization Report for the Planned Quarry Construction Staging Area and Water Treatment Plant: Revision 125

Temporary Storage Area Characterization Report 26

Buildings Radiological Characterization Report for the Weldon Spring Site Remedial Action Project, Weldon Spring, Missouri 31

Radiological Characterization of Nuclear Plants Under Decommissioning - Problems and Experiences 181

Summary of Work on Characterization of the Radioactive Deposits on PWR Primary Circuit Surfaces 204

Radionuclide Characterization of Reactor Decommissioning Waste and Spent Fuel Assembly Hardware 214

Reducing Characterization Costs by 30 Percent Through the Use of an Innovative Drilling Strategy 288

Radiological Characterization Report for FUSRAP Properties in the St. Louis, Missouri, Area - Volume I 289

Radiological Characterization Report for FUSRAP Properties in the St. Louis, Missouri, Area - Volume II: Data Tables 290

Radiological Characterization Report for FUSRAP Properties in the St. Louis, Missouri, Area - Volume III: Data Tables (continued) 291

Biological Characterization of Radiation Exposure and Dose Estimates for Inhaled Uranium Milling Eftluents 327

Remote Site Survey and Characterization for the National Environmental Restoration and Waste Management (ERWM) Program Using the SRIP (Solider Robot Interface Project) Vehicle 376

Cheap Checklist

When a Nuclear Reactor Dies, \$98 Million is a Cheap Funeral 39 Chemical

UMTK\& Project Environmental, Health and Safety Audit Checklist 312

Engineering Evaluation/Cost Analysis for the Proposed Management of Contaminated Water Impounded at the Weldon Spring Chemical Plant Area 21

Radiological and Chemical Characterization Report for the Planned Quarry Construction Staging Area and Water Treatment Plant: Revision 125

Phase 2 Groundwater Quality Assessment for the Weldon Spring Site, Chemical Plant, Raffinate Pits and Surrounding Vicinity Properties 28

Weldon Spring Chemical Plant Water Treatment Plan 41

Composition Models for the Viscosity and Chemical Durability of West Valley Related Nuclear Waste Glasses 112

Chemical Decontamination Method for Stainless Steel 136

Verification of Remedial Action on Ventilation Systems, Jones Chemical Laboratory, University of Chicago, Chicago, Illinois 287

Ground Distribution Patterns of Selected Radioactive, Chemical, and Physical Contaminants from Dispersion of Uranium Mill Tailings 308

Cheney

A Hydrogeologic Field Investigation of the Uranium Mill Tailings Remedial Action Project at the Cheney Tailings Disposal Site. Grand Junction, C lorado 317 


\section{Chernobyl}

Chernobyl: Recovery Operations and the Entombment of Reactor $4 \mathbf{8 6}$ Chicago

Entombment of Chernobyl Unit $4 \quad 160$

Verification of Remedial Action on Ventilation Systems, Jones Chemical Laboratory, University of Chicago, Chicago, Illinois 287

\section{Chlorine}

Extraction of Uranium, Thorium and Radium from an Elliot Lake Radioactive Ore by Chlorine-Assisted Leaching 332

\section{Circuit}

Summary of Work on Characterization of the Radioactive Deposits on PWR Primary Circuit Surfaces 204

Circuits

Immobilization in Cement of Ion Exchange Resins Arising from the Purification of Reagents Used for the Decontamination of Reactor Circuits - Fifth Semestrial Report

Classification July-December 1988145

Classification and Disposal of Radioactive Wastes: History and Legal and Regulatory Requirements 349

Clay

Effects of Vegetation, A Clay Cap and Environmental Variables on Rn-222 Fluence Rate from Reclaimed Uranium Mill Tailings 335

Clean

End to Clean-up Programme in Sight (TMI-2) 251

Cleaning

Improvements of Decommissioning Gaseous Waste Handling by Cleaning Devices Cleaning Laboratory 166

Measurement and Removal of Steel Flame Cutting Aerosols (0.01-1 um) in WAGR Decommissioning Cleaning Laboratory 215

Cicanout

324 and 325 Building Hot Cell Cleanout Program - Decontamination of C-Cell 153

Cleanout and Decontamination of Radiochemical Hot Cells 235

\section{Cleanup}

Plutonium Mining for Cleanup 71

Fersonnel Contamination Protection Techniques Applied During the TMI-2 Cleanup 137 Economic Risk of Contamination Cleanup Costs Resulting from Large Nonreactor Nuclear Material Licensee Operations 203

Cleanup Around an Old Waste Site - A Success Story 298

Effectiveness of Cleanup Criteria Relative to an Accident Nuclear Release 346

Evaluation of Cleanup Levels for Remedial Action at CERCLA Sites Based on a Review of EPA Records of Decision 354

Code

Benchmarking of the Computer Code and the Thirty-Foot Side Drop Analysis for the Shippingport RPV/NST Package 8

Codes

Final Report on Computer Codes for Estimating the Decommissioning Cost of Nuclear Power Plants 206 
Cold Colonic

Construction and Cold Testing of the West Valley Supernatant Treatment System 68

Work Plan for the Remedial Investigation/Feasibility Study - Environmental Assessment for the Colonie Site, Colonic, New York 270

Certification of the Radiological Condition of Thirty-Five Private Properties Located in Colonie and Albany, NY 271

Verification of 1988 Remedial Actions, Vicinity Properties, Colonie Interim Storage Site, Colonie, New York 272

Verification Surveys of Non-Designated Vicinity Properties, Colonie Interim Storage Site, Colonie, NY 273

Colorado

Radiological Surveillance of Remcdial Action Activities at the Processing Site - Durango, Colorado, May 16-18, 1989309

A Hydrogeologic Field Investigation of the Uranium Mill Tailinas Remedial Action Project at the Cheney Tailings Disposal Site, Grand Junction, Colorado 317

Remedial Actions at the Former Union Carbide Corporation Uranium Mill Sites, Rifle, Garfield County, Colorado - Final Environmental Impact Statement, Volume I: Text 321

Remedial Actions at the Former Union Carbide Corporation Uranium Mill Sites, Rifle, Garfield County, Colorado - Final Environmental Impact Statement, Volume II: Appendices 322

Variation in the Annual Average Radon Concentration Measured in Homes in Mesa County, Colorado 344

Commerce

Appendix A to Facility License No. NS-1 Technical Specifications and Bases (Issued as Change No. 10) for the N.S. Savannah Reactor Maritime Administration U.S. Department of Commerce, Amendment No. 7245

\section{Commercial}

Estimated Doses from Decommissioning Activities at Commercial Nuclear Power Stations 187

\section{Committee}

Nuclear Regulation: NRC's Decommissioning Procedures and Criteria Need to Be Strengthened - Report to the Chairman, Environment, Energy, and Natural Resources Subcommittee, Committee on Government Operations, House of Representatives 121

Government Observations on the Second Report from the Committee (Session 1986-87) on

Standpipe Distortion at Hinkley Point 'A' Power Station and the Cost of Decommissioning Magnox Reactors and on the Third Report (Session 1986-87) on the Comparative Effect of Oil and Gas Prices on Activity in the North Sea 144

Comparative Review of U.S. Department of Energy CERCLA Federal Facility Agreements 377

\section{Comparing}

Comparing Laser and Waterjet Cutting 184 


\section{Compensation}

Remedial Action Assessment System (RAAS): Evaluation of Selected Feasibility Studies of CERCLA (Comprehensiye Environmental Response, Compensation, and Liability Act)

\section{Compilation} Hazardous Waste ititas 393

\section{Completion}

Compilation of Contract Research for the Materials Engineering Branch, Division of Engineering 250

Compliance

Completion of Shippingport Reactor Decommissioning 37

Environmental Compliance Assessment Findings for Weldon Spring Site Remedial Action Program 40

Radionuclide Correlations at TMI-2 for 10 CFR 61 Compliance 98

The Environmental Compliance Process at New York FUSRAP (Formerly Utilized Sites Remedial Action Program) Sites 275

\section{Component}

Management Information Systems for Environmental Compliance Activitics 382

Michigan State University TRIGA Nuclear Reactor: Order Authorizing Dismantlement of Facility and Disposition of Component Parts 140

The University of California, Berkeley: Order Authorizing Dismantling of Facility and Disposition of Component Parts 141

Environmental Assessment and Finding of No Significant Impact Regarding Proposed Order Authorizing Dismartling of the Reactor and Decomposition of Component Parts: Michigan State University 178

Environmental Assessment and Finding of No Significant Impact Regarding Proposed Order Authorizing Phase 2 Dismantling of the Reactor and Disposition of Component Parts: The University of California at Los Angeles 179

Environmental Assessment and Finding of No Significant Impact Regarding Proposed Order Authorizing Dismantling of the Reactor and Decomposition of Component Parts 258

\section{Components}

Sampling Plan for the Unconditional Release of Building Materials and Similar Large Components Encountered in Decommissioning 12

Shippingport Station Decommissioning Project: Removal of Piping and Equipment and Removal of Primary System Components - Topical Report $\mathbf{4 4}$

Analysis of Results Obtained with Different Cutting Techniques and Asssociated Filtration Systems for the Dismantling of Radioactive Metallic Compongnts $5 \%$

Thermal Aging of Some Decommissioned Reactor Components and Mcthodology for Life Prediction 79

Investigations on Selected Components after Decommissic aing 242

Principal Components Analysis for Monitoring the West Valley Liquid Fed Ceramic Melter 262

\section{Composition}

Composition Models for the Viscosity and Chemical Durability of West Valley Related Nuclear Waste Glasses 112

West Valley Glass Product Qualification Durability Studies: Effects of Composition, Redox State, Heat Treatment, and Groundwater 209 
Computer

Benchmarking of the Computer Code and the Thirty-Foot Side Drop Analysis for the Shippingport RPV/NST Package 8

Final Report on Computer Codes for Estimating the Decommissioning Cost of Nuclear Power Plants 206

\section{Concentration}

Variation in the Annual Average Radon Concentration Measured in Homes in Mesa County, Colorado 344

\section{Concrete}

Service Life of Concrete $\mathbf{8 0}$

Optimization of Filtering Systems for Various Concrete Decontamination Techniques 94

Study and Optimization of Filter Systems for Separating Dusts and Aerosols Produced in Layers Concrete Decontamination 95

Evaluation of Contamination on Concrete of JPDR Building 103

Explosive Techniques for the Dismantling of Radioactive Concrete Structures 114

Experiment on Water Jet Method Used for Cutting Concrete Which Covers Piping 156

Thermal Techniques for Surface Concrete Decontamination 183

The Use of the Deep Kerfer for Thick, Steel-Reinforced Concrete Cutting 202

Mass Concrete Removal by High-Pressure Water Jet 208

Activated Concrete Cutting Machine (Reactor Decommissioning) 222

Determination of the Long-Lived Nuclides in Biological Shielding Concrete, Ion Exchange

Resin and Fuel Storage Pool Water of IPDR 237

Conditioning

Demolition of Structural Concrete Containing Unbonded Tendons 261

BER II - Dismantling and Conditioning 59

Conducting

Conditioning of Graphite Bricks from Dismantled Gas Cooled Reactors for Disposal 109

Guidelines for Conducting Radiological Surveillances of Remedial Action Activities at

UMTRA Processing Sites 310

\section{Consequence}

Consequence Estimation for Decontaminated Sites and Facilities 188

\section{Conservation}

A Review of State Regulations that Exceed Those of the Federal Resource Conservation and Recovery Act (RCRA) 357

Establishing a Regulatory Framework for a RCRA (Resource, Conservation, and Recovery

\section{Constitucnts}

Act) Corrective Action Program 365

Hazardous Organic Constituents at the UMTRA Title I Sites 319

Leachability of Radioactive Constituents from Uranium Mine Tailings 326

Construction

Radiological and Chemical Characterization Report for the Planned Quarry Construrtion

Staging Area and Water Treatment Plant: Revision 125

Construction and Cold Testing of the West Valley Supernatant Treatment System 68

Constructional

Construction Times and the Decommissioning of Nuclear Power Plants 101

Radon I Dwellings - Testing and Evaluation of Constructional and Buildings Services

Enginecring Measures 296 


\section{Consumable}

Aerosol Generation During Cutting of Various Materials with Plasına, Laser and Consumable Electrode 233

\section{Containment}

Performance Monitoring Report for the Niagara Falls Storage Site Waste Containment Structure, Lewiston, New York, July-December, 1988 and Calendar Year 19895

Shippingport Station Decommissioning Project: Removal of Structures and Containment Contaminant Chambers - Topical Report 46

The Role of Sub-Surface Contaminant Fate and Transport Models for RCRA Land Ban

\section{Contaminants} Regulations 366

The Migration of Ground-Water Contaminants from Uranium Mill Tailings Piles $\mathbf{3 0 2}$

Ground Distribution Patterns of Selected Radioactive, Chemical, and Physical Contaminants

\section{Contaminated} from Dispersion of Uranium Mill Tailings 308

Engineering Evaluation/Cost Analysis for the Proposed Management of Contaminated Water Impounded at the Weldon Spring Chemical Plant Area 21

Experience on Melting of Contaminated Steel Scrap and Treatment of Large Quantities of Low-Level Contaminated Steel for Unrestricted Release 105

Policy and Criteria for the Recycle and Reuse of Very Low Level Contaminated Materials from Maintenance, Refurbishment and Decommissioning of Nuclear Facilities in the Federal Republic of Germany 124

Processing at the Plutonium-Contaminated Waste Treatment Facility 191

Decommissioning of Pu Contaminated Glove Box System 193

Dismantling of an Alpha Contaminated Hot Cell at the Marcoule Pilot Plant 236

Enginecring Evaluation/Cost Analysis for the Proposed Removal of Contaminated Materials from Pad 1 at the Elza Gate Site, Oak Ridge, Tennessee 268

Dispersion of Radium-226 in a Contaminated Environment 294

Volume Estimate of Radium-Contaminated Soil in a Section of Barrows Field Park, Glen Ridge, New Jersey, November-December 1989297

Analysis of Radiological Survey Data to Determine Contaminated Waste Volumes 351

\section{Contamination}

Evaluation of Contamination on Concrete of JPDR Building 103

Personnel Contamination Protection Techniques Applied During the TMI-2 Cleanup 137

Residual Radioactive Contamination from Decommissioning - Technical Basis for Translating Contamination Levels to Actual Dose - Draft Report for Comment 155

The TMI-2 (Three Mile Island Unit 2) P actor Building Gross Decontamination Experiment - Effects on Loose-Surface Contamination Levels 16?

Economic Risk of Contamination Cleanup Costs Resulting from Large Nonreactor Nuclear Material Licensee Operations 203

Contamination in Surface Waters Around Uranium Mines in the Guadiana Basin 325

Impact of Uranium Mining on the Radioactive Contamination of the Agueda River 328

A Field Study Designed to Select the In-Situ Instrument Most Useful for Estimating Uranium Contamination in Soil 348 


\section{Context}

Introducing the Geosocial Context of Nuclear Decommissioning - Policy Implications in the US and Great Britain 195

Radiological Characterization Report for FUSRAP Properties in the St. Louis, Missouri, Area - Volume III: Data Tables (continued) 291

Control

Evaluation of Radon Emissions and Potential Control Requirements 29

Investigation of the Control Rod Material Presence in the TMI-2 Lower Head 130

Pitting and its Control During Electropolishing of Stainless Steel 152

Heat Stress Control in the TMI-2 Defucling and Decontamination Activities 219

Radon Control and Remedics in Buildings Cornwall County Council, County Architects Conversion Department, Truro, United Kingdom 295

Cooled

Conversion of Mixed Waste to LSA Waste: A Case Study 293

Conditioning of Graphite Bricks from Dismantled Gas Cooled Reactors for Disposal 109 Coordination

The Windscale Advanced Gas-Cooled Reactor Stage 3 Decommissioning Project 243

Decontamination and Decommissioning of Nuclear Facilities - Final Report of Three Rescarch Coordination Meetings Held Between 1984 and 1987147

Coping

Coping with the Biggest Dismantling Project in the World - Reactor Decommissioning 15

Core

\section{Cored}

Remote Plasma Cutting on TMI Core 211

Cornwall

Underwater Arc Cutting with a Cored Electrode 88

Radon Control and Remedies in Buildings Cornwall County Council, County Architects Corrective Department, Truro, United Kingdom 295

Establishing a Regulatory Framework for a RCRA (Resource, Conservation, and Recovery Corrclations Act) Corrective Action Program 365 Corrosion

Radionuclide Correlations at TMI- 2 for 10 CFR 61 Compliance 98

Mechanism of Corrosion in Decontaminating Solutions of Stainless Steel and Highly Wear Resistant Hardfacing Alloys for a Liquid Metal Fast Breeder Reactor 100

Cost

Enginecring Evaluation/Cost Analysis for the Proposed Management of Contaminated Water Impounded at the Weldon Spring Chemical Plant Area 21

The Community's Research and Deyelopment Program on Radioactive Waste Management anci Storage, Shared Cost Action - Nuclear Science and Technology Series: Annual Progress Report 83

Cost Estimate Guidelines for Advanced Nuclear Power Technologies 90

Standpipe Distortion at Hinkley Point 'A' Power Station and the Cost of Decommissioning Magnox Reactors 143 
Cost

Government Observations on the Second Report from the Committee (Szssion 1986-87) on Standpipe Distortion at Hinkley Point 'A' Power Station and the Cost of Decommissioning Magnox Reactors and on the Third Report (Session 1986-87) on the Effect of Oil and Gas Prices on Activity in the North Sea 144

Good Plant Practices: A Prelude to Cost Effective Decommissioning 167

Final Report on Computer Codes for Estimating the Decommissioning Cost of Nuclear Power Plants 206

Engineering Evaluation/Cost Analysis for the Proposed Removal of Contaminated Materials from Pad 1 at the Elza Gate Site, Oak Ridge, Tennessec 268

\section{Costing}

Remedial Action Costing Procedures Manual 355

Costs

Economic Risk of Contamination Cleanup Costs Resulting from Large Nonreactor Nuclear Material Licensee Operations 203

Reducing Characterization Costs by 30 Percent Through the Use of an Innovative Drilling Strategy 288

\section{Covers}

Experiment on Water Jet Method Used for Cutting Concrete Which Covers Piping 156

Uranium Mill Facilities: Availability and Request for Public Comment on Draft Technical Position on Design of Erosion Protection Covers 339

$\mathrm{CO} 2$

Crack

New Aspects in Cutting Metals with CO2 Lasers 256

A Model Study of the Water Pressure Distribution in a Crack When Impacted by a High Pressure Water Jet 174

Criteria

Radiological Protection Criteria for the Recycling of Materials from the Dismantling of Nuclear Installations Communities, Luxembourg (Luxembourg) $\mathbf{7 6}$

Radiological Criteria for Unrestricted Release of Materials from Nuclear Installations 77

Nuclear Regulation: NRC's Decommissioning Procedures and Criteria Need to Be Strengthened - Report to the Chairman, Environment, Energy, and Natural Resources Subcommittee, Committee on Government Operations, House of Representatives 121

Policy and Criteria for the Recycle and Reuse of Very Low Level Contaminated Materials from Maintenance, Refurbishment and Decommissioning of Nuclear Facilities in the Federa! Republic of Germany 124

Crystallization

Effectiveness of Cleanup Criteria Relative to an Accident Nuclear Release 346

Cumulation

Crystallization Behavior of a Fully Simulated West Valley Borosilicate Glass 151

Curtis

The Blowdown Water Cannon - A Novel Method for Powering the Cumulation Nozzle 198

Results of the Indoor Radiological Survey at the W.R. Grace Company, Curtis Bay Site, Baltimore, Maryland 274

\section{Cutting}

Comparison Between Laser, Plasma, Waterjet, Oxygen Cutting and Other Mechanical Cutting Processes for Low Thickness (0.5 Un to $5 \mathrm{MM}$ ) 53 


\section{Cutting}

Analysis of Results Obtained with Different Cutting Techniques and Associated Filtration Systems for the Dismantling of Radioactive Metallic Components. 57

Installation for Semiautomatic Air-Plasma Metal Cutting Up to $6 \mathrm{~mm}$ Thickness $\mathbf{6 2}$

Ventilation and Filtration Techniques for Handling Aerosols Produced by Thermal Cutting Operations 65

Rapid Cutting of Pavement with Cavitating Water Jets 84

Underwater Arc Cutting with a Cored Electrode 88

Submerged Cutting of Steel by Abrasive Water Jets 129

Cutting with Abrasive Waterjets 131

Cutting with Abrasive Waterjets 132

Dismantling of JPDR Internals Gets Under Way Using Plasma Arc Cutting 149

Experiment on Water Jet Method Used for Cutting Concrete Which Covers Piping 156

Underwater Plasma Arc Cutting in Three Mile Island's Reactor 175

Comparing Laser and Waterjet Cutting 184

Contact Arc Cutting of Worked-Out Equipment 186

The Use of the Deep Kerfer for Thick, Steel-Reinforced Concrete Cutting 202

Remote Plasma Cutting on TMI Core 211

Measurement and Removal of Steel Flame Cutting Acrosols (0.01-1 um) in WAGR Decommissioning Cleaning Laboratory 215

Activated Concrete Cutting Machine (Reactor Decommissioning) 222

Aerosol Generation During Cutting of Various Materials with Plasma, Laser and Consumable Electrode 233

Waterjet Cutting: Systems Offer Versatility 254

New Asf*: is in Cutting Metals with CO2 Lasers 256

A Look at Air-PAC Machines (Plasma Arc Cutting) 263

30 Years of Experience with Arc Plasma Metal Cutting 267

Dam

Lead Isotopes as Seepage Indicators Around a Uranium Tailings Dam 329

Radium and Heavy Metal Transport Beneath an Abandoned Uranium Tailings Dam 331

DDB

The Decommissioning Data Bank (DDB) - Methodology and Applications 201

Decommissioned

Thermal Aging of Some Decommissioned Reactor Components and Methodology for Life Prediction 79

Study Into the Applicabilities of Lasers for the Dismantling of Decommissioned Nuclear Power Plant 128

Radioactivity Inventories in the Decommissioned Nuclear Power Plant 168

Review of Nuclear Power Plants That Have Been or Will Be Decommissioned Decommissioning Work Carried Out for KKN, FR-2, and MZFR 169

Seismic Research on an Aged United States Gate Valve and on a Piping System in the Decommissioned Heissdampfreaktor (HDR): Summary 231

Seismic Research on an Aged United States Gate Valve and on a Piping System in the Decommissioned Heissdampfreaktor (HDR): Appendices 232 


\section{Decomposition}

Environmental Assessment and Finding of No Significant Impact Regarding Proposed Order Authorizing Dismantling of the Reactor and Decomposition of Component Parts: Michigan State University 178

Environmental Assessment and Finding of No Signilicant Impact Regarding Proposed Order Authorizing Dismantling of the Reactor and Decomposition of Component Parts 258

\section{Decontaminated}

Consequence Estimation for Decontaminated Sites and Facilities 188

\section{Decontaminating}

Mechanism of Corrosion in Decontaminating Solutions of Stainless Stecl and Highly Wear Resistant Hardfacing Alloys for a Liquid Metal Fast Brecder Reactor 1(X)

\section{Decontaminations}

Method of Decontaminating Surface of Radioactive Metal Waste 157

The Impact of Light-Water Reactor Decontaminations on Solidification, Waste Disposal, and Associated Occupational Exposure 226

The Impact of LWR Decontaminations on Solidification, Waste Disposal and Associated

\section{Defense} Occupational Exposure 227

Defense Decontamination and Decommissioning Program 180)

An Overview of the Department of Energy Defense Programs Environmental Restoration Program 368

Department of Energy Defense Programs Environmental Restoration Program Update 369

Environment, Safety and Health Report for the Department of Energy Def'ense Complex: Executive Summary 386

Environment, Safety and Health Report for the Department of Encrgy Defense Complex 387

\section{Defucling}

Fiscal Year 1989 Defense Waste Managemunt and Environmental Program Plan 392

\section{Defuelling}

Heat Stress Control in the TMI-2 Defueling and Decontamination Activitics 219

\section{Democratic}

TMI-2 Defuelling Conditions and Summary of Research Findings 96

Particulars of Regulatory Practice for Nuclear Power Plants in the German Democratic

\section{Demolish} Republic 159

Long Goodbye - Why it Will Take 100 Years to Demolish This (Berkeley) Nuclear Power Station 265

\section{Demolition}

Demolition of E.ructural Corcrete Containing Unbonded Tendons 261

\section{Demonstration}

Three Year's Progress of the West Valley Demonstration Project Vitrification System 61

West Valley Demonstration Project Community Relations Plan FY 1990/91 8?

Public Attitudes Near a Nuclear Waste Site: Survey Trends from the West Valley Demonstration Project 138

An Overview of Waste Management Systems at the West Valley Demonstration Project 176 A.pplied Research, Develnpment, Demonstration, Testing and Evaluation Plan for Environmental Restoration and Waste Management 389 


\section{Department}

Department of the Army Installation Restoration Program 54

TMI-2: Lessons Learned by the U.S. Department of Energy - A Programmatic Perspective 218

A ppendix A to Facility License No. NS-1 Technical Specifications and Bases (Issued as Change No. 10) for the N.S. Savannah Reactor Maritime Administration U.S. Department of Commerce, Amendment No. 7245

Radon Control and Remedics in Buildings Cornwall County Council, County Architects Department, Truro, United Kingdom 295

An Overvicw of Remedial Action Technical Information Support Activities Funded by the U.S. Department of Energy's Office of Environmental Restoration 350

EPA (Environmental Protection Agency) and State Authority Over DOE (Department of Energy) Groundwater Radionuclides 358

The Department of Energy Program for Environmental Restoration 361

An Overview of the Department of Energy Defense Programs Environmental Restoration Program 368

Department of Energy Defense Programs Environmental Restoration Program Update 369

Procecedings of the U.S. Department of Energy Office of Environmental Restoration and Waste Management Waste Reduction Workshop 372

Comparative Review of U.S. Department of Energy CERCLA Federal Facility Agreements 377

Environment, Safety, and Health Needs of the U.S. Department of Energy - Volume 2: Site Summaries 385

Environment, Safety and Health Report for the Department of Energy Defense Complex: Executive Summary 386

Environment, Safety and Health Report for the Department of Energy Defense Complex 387

Deposits

Transferring Generic SARA/OSHA Training to U.S. Department of Energy Facilities 394

Summary of Work on Characterization of the Radioactive Deposits on PWR Primary Circuit Surfaces 204

Design

Conceptual Design for a Land Decontamination Robot 266

Geotechnical Stability Considerations in the Design and Reclamation of Tailings Impoundments 300

Uranium Mill Facilitics: Availability and Request for Public Comment on Draft Techinical Position on Design of Erosion Protection Covers 339

Designed

A Field Study Designed to Select the In-Situ Instrument Most Useful for Estimating Uranium Contamination in Soil 348

Determine

A Fast-Sorting Measurement Technique to Determine Decontamination Priority 92 Diamond

Analysis of Radiological Survey Data to Determine Cuntaminated Waste Volumes 351

Results of the Preliminary Radiological Survey at the Former Diamond Magnesium Company Site, Luckey, Ohio (DML001) 277 


\section{Diffusion}

Environmental Restoration and Waste Management. Site Specific Plan for Oak Ridge Dismantle Operation Office Paducah Gaseous Diffusion Plant 373

Starting to Dismantlu Berkeley (Reactor Decommissioning) 74

Adaption of High-Pressure Water Jets and Abrasives to Dismantle Nuclear Installations 172 Dismantlod

Conditioning of Graphite Bricks from Dismantled Gas Cooled Reactors for Disposal $\mathbf{1 0 9}$ Dismantlement

Michigan State University TRIGA Nuclear Reactor: Order Authorizing Dismantlement of Dismantling Facility and Disposition of Component Parts 140

Strategy for Dismantling $\mathbf{1 0}$

Coping with the Biggest Dismantling Project in the World - Reactor Decommissioning 15

Analysis of Results Obtained with Different Cutting Techniques and Associated Filtration Systems for the Dismantling of Radioactive Metallic Components 57

BER II - Dismantling and Conditioning 59

Dismantling the RB-2 Research Reactor: An Application of a Radiation Protection Approach Relevant to Italy's Decommissioning Methodology 73

Radiological Protection Criteria for the Recycling of Materials from the Dismantling of Nuclear Installations Communities, Luxembourg (Luxembourg) 76

Experience in the Decontamination and Dismantling of Alpha Facilitics 78

Explosir e Techniques for the Dismantling of Radioactive Concrete Structures 114

Study I to the Applicabilities of Lasers for the Dismantling of Decommissioned Nuclear Power Plant 128

The University of California, Berkeley: Order Authorizing Dismantling of Facility and Disposition of Component Parts 141

Dismantling of JPDR Internals Gets Under Way Using Plasma Arc Cutting 149

Environmental Assessment and Finding of No Significant Impact Regarding Proposed Order Authorizing Dismantling of the Reactor and Decomposition of Component Parts: Michigan State University 178

Environmental Assessment and Finding of No Significant Impact Regarding Proposed Order Authorizing Phase 2 Dismantling of the Reactor and Disposition of Component Parts: The University of California at Los Angeles 179

Dismantling Operations During NPP Decommissioning 185

Mechanical Dismantling and Breakdown Methods 190

Installation Dismantling System, Working Process and Hood Utilizable in this System 205

Radiological Protection Principles for the Decommissioning and Dismantling of Nuclear Power Plant - International Activities 216

Licensing and Surveillance of Activities for Decommissioning and Dismantling of Nuclear Power Plant, Shown by the Niederaichbach Reactor as an Example 220

State of Dismantling Reactor Facilities (JPDR) in Tokai Rescarch Establishment, Japan Atomic Energy Research Institute 221

EL-3 Dismantling of an Experimental Reactor 225

Dismantling of an Alpha Contaminated Hot Cell at the Marcoule Pilot Plant 236

The Lawfulness of a Licence for the Dismantling of a Nuclear Power Plant 241 
Dismantling

Environmental Assessment and Finding of No Significant Impact Regarding Proposed Order Dispersion

Authorizing Dismantling of the Reactor and Decomposition of Component Parts 258

Dispersion of Radium-226 in a Contaminated Environment 294

Ground Distribution Patterns of Selected Radioactive, Chemical, and Physical Contaminants

Disposition from Dispersion of Uranium Mill Tailings 308

Michigan State University TRIGA Nuclear Reactor: Order Authorizing Dismantlement of Facility and Disposition of Component Parts 140

The University of California, Berkeley: Order Authorizing Dismantling of Facility and Disposition of Component Parts 141

Environmental Assessment and Finding of No Significant Impact Regarding Proposed Order Authorizing Phase 2 Dismantling of the Reactor and Disposition of Component Parts: Dissolutive The University of California at Los Angeles 179

REDOX Decontamination Technique Development I - Selection for Dissolutive and Distortion Regenerative Conditions 118

Standpipe Distortion at Hinkley Point 'A' Power Station and the Cost of Decommissioning Magnox Reactors 143

Government Observations on the Second Report from the Committee (Session 1986-87) on Standpipe Distortion at Hinkley Point 'A' Power Station and the Cost of Decommissioning Magnox Reactors and on the Third Report (Session 1986-87) on the Distribution Effect of Oil and Gas Prices on Activity in the North Sea 144

A Model Study of the Water Pressure Distribution in a Crack When Impacted by a High Pressure Water Jet 174

Ground Distribution Patterns of Selected Radioactive, Chemical, and Physical Contaminants from Dispersion of Uranium Mill Tailings 308

DMLO01

Influence of Mining Activity on Distribution of Radium in the Natural Environment $\mathbf{3 4 0}$

Results of the Preliminary Radiological Survey at the Former Diamond Magnesium Company Site, Luckey, Ohio (DML001) 277

Dase

Residual Radioactive Contamination from Decommissioning - Technical Basis for Translating Contamination Levels to Actual Dose - Draft Report for Comment 155

Biological Characterization of Radiation Exposure and Dose Estimates for Inhaled Uranium Milling Effluents 327

Doses

Estimated Doses from Decommissioning Activities at Commercial Nuclear Power Stations 187

Drilling

Reducir:g Characterization Costs by 39 Percent Through the Use of an Innovative Drilling Strategy $\mathbf{2 8 8}$ 


\section{Drop}

Benchmarking of the Computer Code and the Thirty-Foot Side Drop Analysis for the Durability Shippingport RPV/NST Package 8

Composition Models for the Viscosity and Chemical Durability of West Valley Related Nuclear Waste Glasses 112

West Valley Glass Product Qualification Durability Studies: Effects of Composition, Redcx Durango State, Heat Treatment, and Groundwater 209

Radiological Surveillance of Remedial Action Activities at the Processing Site - Durango, Colorado, May 16-18, 1989309

Durango Health and Safety Audit 311

\section{Dusts}

Study and Optimization of Filter Systems for Separating Dusts and Acrosols Produced in Dwellings Layers Concrete Decontamination 95

Radon I Dwellings - Testing and Evaluation of Constructional and Buildings Services

D1206 Engineering Measures 296

Earth

The Refurbishment of the D1206 Fuel Reprocessing Plant 58

Hydrochloric Acid Leaching of Uranium, Thorium, Radium and Rare-Earth Elements, from EBWP. an Elliot Lake Radioactive Ore 333

S'atus of the Decontamination and Decommissioning of the Experimental Boiling Water Reactor (EBWR) 7

EC

EC Starts New Research Programme 146

Ecologically

Determination of Ecologically Vital Groundwaters at Selected Sites in the Formerly Utilized

Economic Sites Remedial Action Program 292

Economic Aspects of Decommissioning 150

Economic Risk of Contamination Cleanup Costs Resulting from Large Nonreactor Nuclear Effluents Material Licensee Operations 203

Biological Characterization of Radiation Exposure and Dose Estimates for Inhaled Uranium Milling Effluents 327

Biogenic Approach to the Treatment of Uranium Mill Effluents 334

EL

EL-3 Dismantling of an Experimental Reactor 225

\section{Electric}

Experience Gained with the Decommissioning of Nuclear Power Plant Operated by the Electricity Federal German Electric Utilities 255

Decommissioning of Nuclear Power Plants - Operation Without Generation of Electricity 252 
Electro

Electrochemical

Decontamination of Nuclear Facilities by Electrochemical Methods 199

Electrode

Underwater Arc Cutting with a Cored Electrode $\mathbf{8 8}$

Acrosol Gencration During Cutting of Various Materials with Plasma, Laser and Consumable Electrode 233

\section{Elcctropolishing}

Electropolishing Reduces Exposure Levels 99

Elliot

Pitting and its Control During Electropolishing of Stainless Steel 152

Extraction of Uranium, Thorium and Radium from an Elliot Lake Radioactive Ore by Chlorine-Assisted Leaching 332

Hydrochloric Acid Lcaching of Uranium, Thorium, Radium and Rare-Earth Elements, from an Elliot Lake Radioactive Ore $\mathbf{3 3 3}$

Elza

Enginecring Evaluation/Cost Analysis for the Proposed Removal of Contaminated Materials from Pad 1 at the Elza Gate Site, Oak Ridge, Tennessee 268

\section{Embrittlement}

Irradiation Embrittlement of the Shippingport Neutron Shield Tank 9

Irradiation Embrittlement Investigation of the Shippingport Station Neutron Shield Tank 36

Emissions

Evaluation of Radon Emissions and Potential Control Requirements 29

Plan for Monitoring Radionuclide Emissions Other than Radon at Weldon Spring Site Critical Receptors 32

\section{Encountered}

Sampling Plan for the Unconditional Release of Building Materials and Similar Large

\section{ENFDP} Components Encountered in Decommissioning 12

\section{Enrichment}

Evaluation of Nuclcar Facility Decommissioning Projects (ENFDP) Program 239

\section{Entombment}

Uranium Enrichment and Mill Tailings Reclamation Legislation 338

Chernobyl: Recovery Operations and the Entombment of Reactor 486

\section{Environment}

Entombment of Chernobyl Unit $4 \mathbf{1 6 0}$

Nuclear Regulation: NRC's Decommissioning Procedures and Criteria Need to Be Strengthened - Report to the Chairman, Environment, Energy, and Natural Resources Subcommittee, Committee on Government Operations, House of Representatives 121 Dispersion of Radium-226 in a Contaminated Environment 294

Influence of Mining Activity on Distribution of Radium in the Natural Environment 340 Strategies for Environmental Restoration in an Evolving Regulatory Environment 363

Environment, Satety, and Health Needs of the U.S. Department of Encrgy - Volume 2: Site Summaries $\mathbf{3 8 5}$ 


\section{Environment}

Environment, Safety and Health Report for the Department of Energy Defense Complex: Executive Summary 386

Environment, Safety and Health Report for the Department of Energy Defense Complex 387

EPA

Superfund Record of Decision (EPA Region 8): Monticello Vicinity Properties, Utah (First Remedial Action), September 1989 - Final Report 42

Evaluation of Cleanup Levels for Remedial Action at CERCLA Sites Based on a Review of EPA Records of Decision 354

EPA (Environmental Protection Agency) and State Authority Over DOE (Department of Equipment Energy) Groundwater Radionuclides 358

Shippingport Station Decommissioning Project: Removal of Piping and Equipment and Removal of Primary System Components - Topical Report $\mathbf{4 4}$

Erosion

Contact Arc Cutting of Worked-Out Equipment 186

Uranium Mill Facilities: Availability and Request for Public Comment on Draft Technical

\section{ERWM} Position on Design of Erosion Protection Covers 339

Remote Site Survey and Characterization for the National Environmental Restoration and Waste Management (ERWM) Program Using the SRIP (Solider Robot Interface Project)

Essex Vehicle 376

Results of the Radiological Survey at 160 Essex Street, Lodi, New Jersey (LJ072) 281

Results of the Radiological Survey at 174 Essex Street, Lodi, New Jersey (LJ073) 282

Establishment

State of Dismantling Reactor Facilities (JPDR) in Tokai Research Establishment, Japan

Estimated

Atomic Energy Research Institute 221

Estimated Doses from Decommissioning Activities at Commercial Nuclear Power Stations 187

Estimates

Biological Characterization of Radiation Exposure and Dose Estimates for Inhaled Uranium

Estimating Milling Effluents 327

Final Report on Computer Codes for Estimating the Decommissioning Cost of Nuclear Power Plants 206

A Field Study Designed to Select the In-Situ Instrument Most Useful for Estimating Estimation Uranium Contamination in Soil 348

\section{Eurochemic}

Consequence Estimation for Decontaminated Sites and Facilities 188

The Radioactive Waste Management Program Associated with the Decommissioning of the Former Eurochemic Reprocessing Plant 111 


\section{European}

The European Community's Research and Development Program on the Decommissioning of Nuclear Installations 224

\section{Evolving}

Strategies for Environmental Restoration in an Evolving Regulatory Environment 363

\section{Executive}

Environment, Safety and Health Report for the Department of Energy Defense Complex:

\section{Exhaust}

Executive Summary $\mathbf{3 8 6}$

\section{Experience}

Decommissioning a 60-M-Tall Exhaust Stack 20

Experience in the Decontamination and Dismantling of Alpha Facilities 78

Experience on Melting of Contaminated Steel Scrap and Treatment of Large Quantities of Low-Level Contaminated Steel for Unrestricted Release 105

Licensing Authority Experience and Policy for Decommissioning of Nuclear Installations 164

Experience Gained with the Decommissioning of Nuclear Power Plant Operated by the Federal German Electric Utilities 255

30 Years of Experience with Arc Plasma Metal Cutting 267

Decommissioning of Uranium Mines and Mills - Canadian Regulatory Approach and Experiences Experience 341

Radiological Characterization of Nuclear Plants Under Decommissioning - Problems and Explosive Experiences 181 Exposure

Explosive Techniques for the Dismantling of Radioactive Concrete Structures 114

Baseline Risk Evaluation for Exposure to Bulk Wastes at the Weldon Spring Quarry, Weldon Spring, Missouri 14

Electropolishing Reduces Exposure Levels 99

The Impact of Light-Water Reactor Decontaminations on Solidification, Waste Disposal, and Associated Occupational Exposure 226

The Impact of LWR Decontaminations on Solidification, Waste Disposal and Associated Occupational Exposure 227

Biological Characterization of Radiation Exposure and Dose Estimates for Inhaled Uranium Extraction Milling Effluents 327

Extraction of Uranium, Thorium and Radium from an Elliot Lake Radioactive Ore by Fabricating

Chlorine-Assisted Leaching 332

Fabrication

Decommissioning of a Mixed Oxide Fuel Fabricating Facility 75

The Decommissioning of Large and Complex Glove Box Structures in a Mixed Oxide Fuel Fabrication Plant 93 Facing

Decontamination and Decommissioning of a Plutonium Fabrication Facility 259

Facing the Next Hurdle: Dealing with Decommissioning Wastes (Decontamination) 70 
Faith

Fate

Decommissioning at Ground Level - Sizewell and the Uncertaintics of Faith 196

The Role of Sub-Surface Contaminant Fate and Transport Models for RCRA Land Ban Regulations 366

Federal

Policy and Criteria for the Recycle and Reuse of Very Low Level Contaminatec Materials from Maintenance, Refurbishment and Decommissioning of Nuclear Facilities in the Federal Republic of Germany 124

Decommissioning Plans and Programs in the Federal Republic of Germany 170

Experience Gained with the Decommissioning of Nuclear Power Plant Operated by the Federal German Electric Utilities 255

A Review of State Regulations that Exceed Those of the Federal Resource Conservation and Recovery Act (RCRA) 357

Comparative Review of U.S. Department of Energy CERCLA Federal Facility Agreements 377

Fifth

Model Provisions for DOE Federal Facility Agreements 378

Immobilization in Cement of Ion Exchange Resins Arising from the Purification of Reagents Used for the Decontamination of Reactor Circuits - Fifth Semestrial Report July-December 1988145

Filter

Study and Optimization of Filter Systems for Separating Dusts and Aerosols Produced in Layers Concrete Decontamination 95

Filtering

Optimization of Filtering Systems for Various Concrete Decontamination Techniques 94

Filtration

Analysis of Results Obtained with Different Cutting Techniques and Associated Filtration Systems for the Dismantling of Radioactive Metallic Components 57

Ventilation and Filtration Techniques for Handling Aerosols Produced by Thermal Cutting Operations 65

Financial

Materials Licensee Financial Assurance Guidance Related to Decommissioning: Availability 63

Standard Format and Content Guide for Financial Assurance Mechanisms Required for Decommissioning Under 10 CFR parts 30, 40, 70, and 72 - Revision 1247

Standard Review Plan for the Review of Financial Assurance Mechanisms for Decommissioning Under 10 CFR Parts 30, 40, 70, and 72 - Revision 1248

Flame

Measurement and Removal of Steel Flame Cutting Aerosols (0.01-1 um) in WAGR Decommissioning Clcaning Laboratory 215

Fluence

Environmental Effects on Rn-222 Fluence Rate from Reclaimed Uranium Tailings 318

Effects of Vegetation, A Clay Cap and Environmental Variables on Rn-222 Fluence Rate from Reclaimed Uranium Mill Tailings 335

Focus

Radioactive Waste Focus 82 
Follics

The End of the Nuclear Follies 134

Foot

Forest

Benchmarking of the Computer Code and the Thirty-Foot Side Drop Analysis for the Shippingport RPV/NST Package 8

Surveillance of Site A and Plot M in the Palos Park Forest Preserve - 1989286

White King/Luck Lass Mine Remedial Action Project, Freemont National Forest, Lake County, OR. 337

FR

Review of Nuclear Power Plants That Have Been or Will Be Decommissioned Decommissioning Work Carricd Out for KKN, FR-2, and MZFR 159

France

Main Approaches to NPP Decommissioning and to the Radioactive Waste Problem to be Solved in France $\mathbf{6 6}$

Frecmont

White King/Luck Lass Mine Remedial Action Project, Freemont National Forest, Lake County, OR 337

Fucl

The Refurbishment of the D1206 Fuel Reprocessing Plant 58

Decommissioning of a Mixed Oxide Fucl Fabricating Facility 75

The Decommissioning of Large and Complex Glove Box Structures in a Mixed Oxide Fuel Fabrication Plant 93

Decommissioning of Nuclear Fuel Facilities 107

Radionuclide Characterization of Reactor Decommissioning Waste and Spent Fuel Assembly Hardware 214

Determination of the Long-Lived Nuclides in Biological Shielding Concrete, Ion Exchange Resin and Fuel Storage Pool Water of JPDR 237

Integrated Data Base for 1989 - Spent Fuel and Radioactive Waste Inventories, Projections, and Characteristics 345

Fucls

Development of Bagless Transfer Systems at British Nuclear Fucls Limited (BNFL) 56

Decommissioning in British Nuclear Fucls PLC 81

Fundamental

Site-Directed Subsurface Environmental Initiative: Five Year Summary and Plan for FUSRAP

Fundamental Research in Subsoils and in Groundwater, FY 1989-FY 1993380

The Environmental Compliance Process at New York FUSRAP (Formerly Utilized Sites Remedial Action Program) Sius 275

Implementation of an Integrated CERCLA-NEPA Environmental Process at a FUSRAP Site 276

Radiological Characterization Report for FUSRAP Properties in the St. Louis, Missouri, Area - Volume I 289

Radiological Characterization Report for FUSRAP Properties in the St. Louis, Missouri, Area - Volume II: Data Tables 290

Radiological Characterization Report for FUSRAP Properties in the St. Louis, Missouri, Area - Volume III: Data Tables (continued) 291 


\section{Gamma}

GAO

Gamma and Beta Logging of Underground Sewer and Process Lines 343

GAO's Views on DOE's Environmental Restoration and Waste Management Five-Year Plan 374

\section{Garficld}

Remedial Actions at the Former Union Carbide Corporation Uranium Mill Sites, Rifle, Garfield County, Colorado - Final Environmental Impact Statement, Volume I: Text 321

Remedial Actions at the Former Union Carbide Corporation Uranium Mill Sites, Rifle, Garfield County, Colorado - Final Environmental Impact Statement, Volume II: Appendices 322

\section{Garigliano}

Decommissioning of Garigliano Nuclear Power Station 123

Gas

Conditioning of Graphite Bricks from Dismantlea Gas Cooled Reactors for Disposal 109

Government Observations on the Second Report from the Committee (Session 1986-87) on

Standpipe Distortion at Hinkley Point 'A' Power Station and the Cost of Decommissioning Magnox Reactors and on the Third Report (Session 1986-87) on the Effect of Oil and Gas Prices on Activity in the North Sea 144

The Windscale Advanced Gas-Cooled Reactor Stage 3 Decommissioning Project 243

\section{Gaseous}

Development of an Advanced Off-Gas Scrubber for an Incinerating Melter 253

Improvements of Decommissioning Gaseous Waste Handling by Cleaning Devices Cleaning Laboratory 166

Environmental Restoration and Waste Management Site Specific Plan for Oak Ridge Operation Office Paducah Gaseous Diffusion Plant 373

Gate

Seismic Research on an Aged United States Gate Valve and on a Piping System in the Decommissioned Heissdampfreaktor (HDR): Summary 231

Seismic Research on an Aged United States Gate Valve and on a Piping System in the Decommissioned Heissdampfreaktor (HDR): Appendices 232

Engineering Evaluation/Cost Analysis for the Proposed Removal of Contaminated Materials Geochemical from Pad 1 at the Elza Gate Site, Oak Ridge, Tennessee 268

Geochemical Aspects of Seepage from Mill Tailings 313

Geomorphic

Feasibility Study of Geomorphic Research for the Long Term Management of Uranium Mill Geophysical Tailings 336

History and Geophysical Description of Hazardous Waste Disposal Area A Technical Area Geosocial 21284

Introducing the Geosocial Context of Nuclear Decommissioning - Policy Implications in the US and Great Britain 195 


\section{Geotechnical}

Geotechnical Stability Considerations in the Design and Reclamation of Tailings Impoundments $\mathbf{3 0 0}$

\section{German}

Geotechnical Properties of Hydraulically Placed Uranium Mill Tailings 314

Particulars of Regulatory Practice for Nuclear Power Plants in the German Democratic Republic 159

Experience Gained with the Decommissioning of Nuclear Power Plant Operated by the Federal German Electric Utilities 255

\section{Germany}

Pulicy and Criteria for the Recycle and Reuse of Very Low Level Contaminated Materials from Maintenance, Refurbishment and Decommissioning of Nuclear Facilities in the Federal Republic of Germany 124

Decommissioning Plans and Programs in the Federal Republic of Germany 170

Glass

Crystallization Behavior of a Fully Simulated West Valley Borosilicate Glass 151

West Valley Glass Product Qualification Durability Studies: Effects of Composition, Redox State, Heat Treatment, and Groundwater 209

Glasses

Development of QC and Predictive Leach Tests for West Valley Glasses 60

Composition Models for the Viscosity and Chemical Durability of West Valley Related Nuclear Waste Glasses 112

Glen

Volume Estimate of Radium-Contaminated Soil in a Section of Barrows Field Park, Glen Ridge, New Jersey, November-December 1989297

Glove

The Dr commissioning of Large and Complex Glove Box Structures in a Mixed Oxide Fuel Fäbrication Plant 93

GPU

Decommissioning of Pu Contaminated Glove Box System 193

GPU Nuclear Corporation: Availability of Final Supplement 3 to the Programmatic Environmental Impact Statement Related to Decontamination and Disposal of Wastes from March 28, 1979 Accident Three Mile Island Nuclear Station, Unit 2234

Grace

Results of the Indoor Radiological Survey at the W.R. Grace Company, Curtis Bay Site, Baltimore, Maryland 274

Grand

A Hydrogeologic Ficld Investigation of the Uranium Mill Tailings Remedial Action Project at the Chency Tailings Disposal Site, Grand Junction, Colorado 317

Graphical

Graphical Quality Assurance and Data Management on the UMTRA Project 316 Graphitc

Conditioning of Graphite Bricks from Dismantled Gas Cooled Reactors for Disposal 109

Gross

The TMI-2 (Threc Mile Island Unit 2) Reactor Building Gross Decontamination Experiment

- Effects on Loosc-Surface Contamination Levels 165 


\section{Ground}

Decommissioning at Ground Level - Sizewell and the Uncertainties of Faith 196 The Migration of Ground-Water Contaminants from Uranium Mill Tailings Piles 302

Ground Distribution Patterns of Selected Radioactive, Chemical, and Physical Contaminants

\section{Groundwater}

from Dispersion of Uranium Mill Tailings 308

Characierization of Preferred Groundwater Migration Pathways Weldon Spring Site 23

Phase 2 Groundwater Quality Assessment for the Weldon Spring Site, Chemical Plant, Raffinate Pits and Surrounding Vicinity Properties 28

West Valley Ǵlass Product Qualification Durability Studies: Effects of Composition, Redox

State, Heat Treatment, and Groundwater 209

Remediation Through Groundwater Recovery Treatment 353

EPA (Environmental Protection Agency) and State Authority Over DOE (Department of Energy) Groundwater Radionuclides 358

Site-Directed Subsurface Environmental Initiative: Five Year Summary and Plan for Groundwaters

Fundamental Research in Subsoils and in Groundwater, FY 1989-FY 1993380

Determination of Ecologically Vital Groundwaters at Selected Sites in the Formerly Utilized Guadiana

Sites Remedial Action Program 292

\section{Guidelines}

Contamination in Surface Waters Around Uranium Mines in the Guadiana Basin 325

Cost Estimate Guidelines for Advanced Nuclear Power Technologies 90

A Manual for Implementing Residual Radioactive Material Guidelines 285

Guidelines for Conducting Radiological Surveillances of Remedial Action Activities at UMTRA Processing Sites $\mathbf{3 1 0}$

Guides

Residual Radioactive Material Guidelines: Methodology and Applications 352

\section{Gundremmingen}

Draft Regulatory Guides: Issuance and Availability 69

Radiological Safety Aspects of Decontamination Methods - Decontamination Method

Applied in the Decommissioning of the Gundremmingen Nuclear Power Station 163

\section{Hancock}

Decommissioning of the Gundremmingen Nuclear Power Station, Unit A 230 Hanford

Results of the Radiological Survey at 6 Hancock Street, Lodi, New Jersey (LJ033) 283

The Hanford Reservation Environmental Restoration and Waste Management Five-Year Hardfacing

Plan Activity Data Sheets 383

Mechanism of Corrosion in Decontaminating Solutions of Stainless Stcel and Highly Wear Hardware

Resistant Hardfacing Alloys for a Liquid Metal Fast Brecder Reactor 100

Radionuclide Characterization of Reactor Decommissioning Waste and Spent Fucl Assembly Hardware 214

Hazardous

History and Geophysical Description of Hazardous Waste Disposal Area A Technical Area 21284 


\section{Hazardous}

Hazardous and Mixed Waste Managurnent at UMTRA Sites $\mathbf{3 0 6}$

Hazardous Organic Constituents at the UMTRA Title I Sites 319

Remediation of Hazardous Waste Sites: Planning and Integration Requirements 359

Status Report for the Working Group on Hazardous and Mixed Waste 379

Remedial Action Assessment System (RAAS): Evaluation of Selected Feasibility Studies of CERCLA (Comprehensive Environmental Response, Compensation, and Liability Act) Hazardous Waste Sites 393

Hazards

The Risk Assessment of Environmental and Human Hazards 34

HDR

Seismic Research on an Aged United States Gate Valve and on a Piping System in the Decommissioned Heissdampfreaktor (HDR): Summary 231

Seismic Research on an Aged United States Gate Valve and on a Piping System in the Decommissioned Heissdampfreaktor (HDR): Appendices 232

Health

Multimedia Assessment of Health Risks for the Weldon Spring Site Remi tial Action Project 13

Radiological Surveillances and Health and Safety Audits at UMTRA Sites 305

Durango Health and Safety Audit 311

UMTRA Project Environmental, Health and Safety Audit Checklist 312

Health Effects of Uranium Mining 330

Environment, Safety, and Health Needs of the U.S. Department of Energy - Volume 2: Site Summaries 385

Environment, Safety and Health Report for the Department of Energy Defense Complex: Executive Summary 386

Environment, Safety and Health Report for the Department of Energy Defense Complex 387

Heat

Final Report: Decontamination and Decommissioning of Heat Transfer Reactor Experiment Test Assemblics HTRE-2 and HTRE-3 22

West Valley Glass Product Qualification Durability Studies: Effects of Composition, Redox State, Heat Treatment, and Groundwater 209

Heat Stress Control in the TMI-2 Defueling and Decontamination Activities 219

Heavy

Radium and Heavy Metal Transport Beneath an Abandoned Uranium Tailings Dam 331 Heissdampfreaktor

Seismic Research on an Aged Uniied States Gate Valve and on a Piping System in the Decommissioned Heissdampfreaktor (HDR): Summary 231

Seismic Research on an Aged United States Gate Valve and on a Piping System in the Hinkley Decommissioned Heissdampfreaktor (HDR): Appendices 232

Standpipe Distortion at Hinkley Point 'A' Power Station and the Cost of Decommissioning Magnox Reactors 143 
Hinkley

Government Observations on the Second Report from the Committee (Session 1986-87) on Standpipe Distortion at Hinkley Point 'A' Power Station and the Cost of Decommissioning Magnox Reactors and on the Third Report (Session 1986-87) on the Effect of Oil and Gas Prices on Activity in the North Sea 144

History

History and Geophysical Description of Hazardous Waste Disposal Area A Technical Area 21284

Classification and Disposal of Radioactive Wastes: History and Legal and Regulatory Requirements 349

Homes

Variation in the Annual Average Radon Concentration Measured in Homes in Mesa County, Colorado 344

Honing

Hood

Development of Electro-Honing Decontamination Technique 104

Hot

Installation Dismantling System, Working Process and Hood Utilizable in this System 205

324 and 325 Building Hot Cell Cleanout Program - Decontamination of C-Cell 153

Cleanout and Decontamination of Radiochemical Hot Cells 235

House

Dismantling of an Alpha Contaminated Hot Cell at the Marcoule Pilot Plant 236

Nuclear Regulation: NRC's Decommissioning Procedures and Criteria Need to Be Strengthened - Report to the Chairman, Environment, Energy, and Natural Resources

HTRE Subcommittee, Committee on Government Operations, House of Representatives 121

Final Report: Decontamination and Decommissioning of Heat Transfer Reactor Experiment Test Assemblies HTRE-2 and HTRE-3 22

\section{Human}

The Risk Assessment of Environmental and Human Hazards 34

Decontamination and Decommissioning, License Renewal, Human Factors, Generic Issues,

Risk Analysis/PRA Applications; Innovative Concepts for Increased Safety of Advanced

Hurdle Power Reactors 257

Hydraulically

Facing the Next Hurdle: Dealing with Decommissioning Wastes (Decontamination) 70

Hydro

Geotechnical Properties of Hydraulically Placed Uranium Mill Tailings 314

Proposed Safeguards and Security During Future Decommissioning of Ontario Hydio's Reactors 116

Hydrochloric

Hydrochloric Acid Leaching of Uranium, Thorium, Radium and Rare-Earth Elements, from Hydrogeologic an Elliot Lake Radioactive Ore $\mathbf{3 3 3}$

A Hydrogeologic Field Investigation of the Uranium Mill Tailings Remedial Action Project at the Cheney Tailings Disposal Site, Grand Junction, Colorado 317 
IAEA

Proposed IAEA Programme on Safety Aspects of Nwclear Power Plant Aging and Life Extension 194

Illinois

Verification of Remedia: Action on Ventilation Systems, Jones Chemical Laboratory, University of Chicago, Chicago, Illinois 287

\section{Immobilization}

Immobilization in Cement of Ion Exchange Resins Arising from the Purification of Reagents Used for the Decontamination of Reactor Circuits - Fifth St nestrial Report July-December 1988145

Impact

A Structurat Evcluation of the Shippingport Reactor Pressure Vessel for Transport Impact Conditions 49

Environmental Assessment and Finding of No Significani Impact Regarding Proposed Order Authorizing Dismantling of the Reactor and Decomposition of Component Parts: Michigan State University 178

Environmental Assessment and Finding of No Signifi:ant Impact Regarding Proposed Order Authorizing Phase 2 Dismantling of the Reactor and Disposition of Component Parts: The University of California at Los Angeles 179

The Impact of Light-Water Reactor Decontaminations on Solidification, Waste Disnosal, and Associated Occupational Exposure 226

The Impact of LWR Decontaminations on Solidification, Waste Disposal and Associated Occupational Exposure 227

GPU Nuclear Corporation: Availability of Final Supplement 3 to the Programmatic Environmental Impact Statement Related to Decontamination and Disposal of Wastes from March 28, 1979 Accident Three Mile Island Nuclear Station, Unit 2234

Environmental. Assessment and Finding of No Significant Impact Regarding Proposed Oider Authorizing Dismantling of the Reactor and Decomposition of Component Parts 258

Work Plan for the Remedial Investigation/Feasibility Study - Environmental Impact Statement for the Maywood Site, Maywood, New Jersey 269

Remedial Actions at the Former Union Carbide Corporation Uranium Mill Sites, Rifle, Garfield County, Colorado - Final Environmental Impact Statement, Volume I: Text 321

Remedial Actions at the Former Union Carbide Corporation Uranium Mill Sites, Rifle, Garficld County, Colorado - Final Environmental Impact Statement, Volume II: Appendices 322

Impounded

Impact of Uranium Mining on the Radioactive Contamination of the Agueda $\Gamma$ :ver 328

Enginecring Evaluation/Cost Analysis for the Proposed Management of Contaminated Water Impoundments Impounded at the Weldon Spring Chemical Plant Area 21

Geotechnical Stability Considerations in the Design and Reclamation of Tailings Incinerating Impoundments 300

\section{Indicators}

Development of an Advanced Off-Gas Scrubber for an Incinerating Melter 253

Lead Isotopes as Secpage Indicators Around a Uranivm Tailings Dam 329 


\section{Indoor}

R.esults of the Indoor Radiological Survey at the W.R. Grace Company, Curtis Bay Site, Baltimore, Maryland 274

Industry

Measurement and Sorting Techniques Qualified for Unrestricted Release of Metals from the Nuclear Industry 102

Information

Present Status and Problems of Remote Systems Technology in Nuclear Industry 207

An Information System for the Management of Decommissioning Wastes 110

An Overview of Remedial Action Technical Information Support Activities Funded by the U.S. Department of Energy's Office of Environmental Restoration 350

Information Management Systems for Integrating the Technical Data and Regulatory Requirements of Environmental Restoration Activities 360

Inhaled

Mrnagement Information Systems for Environmental Compliance Activities 382

Biological Characterization of Radiation Exposure and Dose Estimates for Inhaled Uraniun. Milling Effluents 327

Initiative

Site-Directed Subsurface Environmental Initiative: Five Year Summary and Plan for Fundamental Research in Subsoils and in Groundwater, FY 1989-FY 1993380

Innovative

Decontamination and Decommissioning, License Renewal, Human Factors, Generic Issues, Risk Analysis/PRA Applications, Innovative Concepts for Increased Safety of Advanced Power Reactors 25\%

Reducing Characterization Costs by 30 Percent Through the Use of an Innovative Drilling Institute Strategy 288

State of Dismantling Reactor Facilities (JPDR) in Tokai Research Establishment, Japan Institutional Atomic Energy Research Institute 221

Institutional Factors. Affecting DOE Waste Management and Environmental Restoration Instrument Planning 390

A Field Study Designed to Select the In-Situ Instrument Most Useful for Estimating Uranium Contamination in Soil 348

\section{Integration} Interface

Remediation of Hazardous Waste Sites: Planning and Integration Requirements 359

Remote Site Survey and Characterization for the National Environmental Restoration and Waste Management (ERWM) Program Using the SRIP (Solider Robot Interface Project)

\section{Internals} Vehicle 376

\section{Inventories}

Dismantling of JPDR Internals Gets Under Way Using Plasma Arc Cutting 149

Kadioactivity Inventories in the Decommissioned Nuclear Power Plant 168

Integrated Data Base for 1989 - Spent Fuel and Radioactive Waste Inventories, Projections, and Characteristics 345 
Inventory

Activity Inventory of the Activated Decommissioning Waste of the Loviisa Nuclear Power Plant 55

Ion

Immobilization in Cement of Ion Exchange Resins Arising from the Purification of Reagents Used for the Decontamination of Reactor Circuits - Fifth Semestrial Report July-December 1988145

Determination of the Long-Lived Nuclides in Biological Shielding Concrete, Ion Exchange Resin and Fuel Storage Pool Water of JPDR 237

Irradiation

Irradiation Embrittlement of the Shippingport Neutron Shield Tank 9

Irradiation Embrittlement Investigation of the Shippingport Station Neutron Shield Tank 36

Isolation

Assessment of Ash Pond Isolation Project Effectiveness 33

Isotopes

Lead Isotopes as Seepage Indicators Around a Uranium Tailings Dam 329

Isstad

Appendix A to Facility License No. NS-1 Technical Specifications and Bases (Issued as Change No. 10) for the N.S. Savannah Reactor Maritime Administration U.S. Department of Commerce, Amendment No. 7245

Italy

JAERI

Dismantling the RB-2 Research Reactor: An Application of a Radiation Protection Approach Relevant to Italy's Decommissioning Methodology 73

Research Program of Decommissioning Material Reuse in JAERI 108

Japan

State of Dismantling Reactor Facilities (JPDR) in Tol:ai Research Establishment, Japan Atomic Energy Research Institute 221

Jersey

Work Plan for the Remedial Investigation/Feasibility Study - Environmental Impact Statement for the Maywood Site, Maywood, New Jersey 269

Resul's of the Radiological Survey at 90 C Avenue, Lodi, New Jarsey (LJ079) 278

Results of the Radiological Survey at 113 Avenue E, Lodi, New Jersey (LJ081) 279

Results of the Radiological Survey at 79 Avenue B, Lodi, New Jersey (LJ091) 280

T.Kesults of the Radiological Survey at 160 Essex Street, Lodi, New Jersey (LJ072) 281

Results of the Radiological Survey at 174 Essex Street, Lodi, New Jersey (LJ073) 282

Results of the Radiological Survey at 6 Hancock Street, Lodi, New Jersey (LJ033) 283

Volume Estimate of Radium-Contaminated Soil in a Section of Barrows Field Park, Glen Ridge, New Jersey, November-December 1989297

Jet

Experiment on Water Jet Method Used for Cutting Concrete Which Covers Piping 156 A Model Study of the Water Pressure Distribution in a Crack When Impacted by a High Pressure Water Jet 174

Mass Concrete Removal by High-Pressure Water Jet 208

Jets

Rapid Cutting of Pavement with Cavitating Water Jets 84 
Jets

Submerged Cutting of Steel by Abrasive Water Jets 129

Journal

Adaption of High-Pressure $W$ ater Jets and Abrasives to Dismantle Nuclear Installations 172

JPDR

Journal of the RANDEC 212

Evaluation of Contamination on Concrete of JPDR Building 103

Dismantling of JPDR Internals Gets Under Way Using Plasma Arc Cutting 149

State of Dismantling Reactor Facilities (JPDR) in Tokai Research Establishment, Japan Atomic Energy Research Institute 221

Determination of the Long-Lived Nuclides in Biological Shielding Concrete, Ion Exchange Resin and Fuel Storage Pool Water of IPDR 237

Kerfer

JPDR NPP Decommissioning 238

King

The Use of the Deep Kerfer for Thick, Steel-Reinforced Concrete Cutting 202

White King/Luck Lass Mine Remedial Action Project, Freemont National Forest, Lake County, OR 337

Laser

Comparison Between Laser, Plasma, Waterjet, Oxygen Cutting and Other Mechanical Cutting Processes for Low Thickness (0.5 Up to $5 \mathrm{MM}) 53$

Comparing Laser and Waterjet Cutting 184

Aerosol Generation During Cutting of Various Materials with Plasma, Laser and Consumable Electrode 233

Lasers

Study Into the Applicabilities of Lasers for the Dismantling of Decommissioned Nuclear Power Plant 128

New Aspects in Cutting Metals with CO2 Lasers 256

Lass

White King/Luck Lass Mine Remedial Action Project, Freemont National Forest, Lake County, OR 337

Latina

Operator Action Model in the Probabilistic Safety Study of Latina MAGNOX Nuclear Power Plant 127

\section{Lawfulness}

Layers

The Lawfulness of a Licence for the Dismantling of a Nuclear Power Plant. 241

Study and Optimization of Filter Systems for Separating Dusts and Aerosols Produced in Layers Concrete Decontamination 95

Leach

Development of QC and Predictive Leach Tests for West Valley Glasses 60 Leachability Leaching

Leachability of Radioactive Constituents from Uranium Mine Tailings 326

Extraction of Uranium, Thorium and Radium from an Elliot Like Radioactive Ore by Chlorine-Assisted Leaching $\mathbf{3 3 2}$ 
Leaching

Hydrochloric Acid Leaching of Uranium, Thorium, Radium and Rare-Earth Elements, from an Elliot Lake Radioactive Ore 333

Lead

Lead Isotopes as Seepage Indicators Around a Uranium Tailings Dam 329

Legal

Classification and Disposal of Radioactive Wastes: History and Legal and Regulatory Requirements 349

\section{Legislation}

Uranium Enrichment and Mill Tailings Reclamation Legislation 338

\section{Lewiston}

Performance Monitoring Report for the Niagara Falls Storage Site Waste Containment

Liability

Structure, Lewiston, New York, July-December, 1988 and Calendar Year 19895

Remedial Action Assessment System (RAAS): Evaluation of Selected Feasibility Studies of CERCLA (Comprehensive Environmental Response, Compensation, and Liability Act) Hazardous Waste Sites 393

Licence

The Lawfulness of a Licence for the Dismantling of a Nuclear Power Plant 241 License

Appendix A to Facility License No. NS-1 Technical Specifications and Bases (Issued as Change No. 10) for the N.S. Savannah Reactor Maritime Administration U.S. Department of Commerce, Amendment No. 7245

Decontamination and Decommissioning, License Renewal, Human Factors, Generic Issues, Risk Analysis/PRA Applications, Innovative Concepts for Increased Safety of Advanced Licensee Power Reactors 257

Materials Licensee Financial Assurance Guidance Related to Decommissioning: Availability 63

Economic Risk of Contamination Cleanup Costs Resulting from Large Nonreactor Nuclear Material Licensee Operations 203

Licensees

Standard Format and Content for Decommissioning Plans for Licensees Under 10 CFR Parts Licensing 30,40 , and 70249

Licensing Authority Experience and Policy for Decommissioning of Nuclear Installations 164

Licensing and Surveillance of Activities for Decommissioning and Dismantling of Nuclear Power Plant, Shown by the Niederaichbach Reactor as an Example 220

Lift

Light

Lift of Shippingport Reactor Pressure Vessel 11

The Impact of Light-Water Reactor Decontaminations on Solidification, Waste Disposal, and Associated Occupational Exposure 226

Liquid

Mechanism of Corrosion in Decontaminating Solutions of Stainless Steel and Highly Wear Resistant Hardfacing Alloys for a Liquid Metal Fast Breeder Reactor 100 


\section{Liquid}

Principal Components Analysis for Monitoring the West Valley Liquid Fed Ceramic Melter 262

Lodi

Results of the Radiological Survey at 90 C Avenue, Lodi, New Jersey (LJ079) 278

Results of the Radiological Survey at 113 Avenue E, Lodi, New Jersey (LJ081) 279

Results of the Radiological Survey at 79 Avenue B, Lodi, New Jersey (LJ091) 280)

Results of the Radiological Survey at 160 Essex Street, Lodi, New Jersey (LJ072) 281

Results of the Radiological Survey at 174 Essex Street, Lodi, New Jersey (LJ073) 282.

\section{Logging}

Results of the Radiological Survey at 6 Hancock Strect, Lodi, New Jersey (LJ033) 283

Loose

Gamma and Beta Logging of Underground Sewer and Process Lines 343

The TMI-2 (Three Mile Island Unit 2) Reactor Building Gross Decontamination Experiment - Effects on Loose-Surface Contamination Levels 165

\section{Louis}

Radiological Characterization Report for FUSRAP Properties in the St. Louis, Missouri, Area - Volume I 289

Radiological Characterization Report for FUSRAP Propertics in the St. Louis, Missouri, Area - Volume II: Data Tables 290

Radiological Characterization Report for FUSRAP Properties in the St. Louis, Missouri, Area - Volume III: Da!a Tables (continued) 291

\section{Loviisa}

Activity Inventory of the Activated Decommissioning Waste of the Loviisa Nuclear Power Plant 55

LSA

Conversion of Mixed Waste to LSA Waste: A Case Study 293

Luck

White King/Luck Lass Mine Remedial Action Project, Freemont National Forest, Lake County, OR 337

Luckey

Results of the Preliminary Radiological Survey at the Former Diamond Magnesium Company

Site, Luckey, Ohio (DML001) 277

Luxembourg

Radiological Protection Criteria for the Recycling of Materials from the Dismantling of Nuclear Installations Communities, Luxembourg (L,uxembourg) 76

LWR

Research and Development of LWR System Decontamination - Mechanochemical and Redox Decontamination Methods 154

The Impact of LWR Decontaminations on Solidification, Waste Disposal and Associated Occupational Exposure 227

Machine

Research and Development of a Machine for the Removing System of Biological Shield Wall of a Nuclear Reactor 120

Development of Rock Bed Boring Machine Using Ultra-High Pressure Water 142

Activated Concrete Cutting Machine (Reactor Decommissioning) 222 


\section{Machines}

A Look at Air-PAC Machines (Plasma Arc Cutting) 263 Magnesium

Results of the Preliminary Radiological Survey at the Former Diamond Magnesium Company Magnox Site, Luckey, Ohio (DMLO01) 277

Operator Action Model in the Probabilistic Safety Study of Latina MAGNOX Nuclear Power n'ant 127

Standpipe Distortion at Hinkley Point 'A' Power Station and the Cost of Decommissioning Magnox Reactors 143

Government Observations on the Second Report from the Committee (Session 1986-87) on Standpipe Distortion at 'Hinkley Point 'A' Power Station and the Cost of Decommissioning Magnox Reactors and on the Third Report (Session 1986-87) on the Effect of Oil and Gas Prices on Activity in the North Sea 144

Factors Influencing the Decommissioning of Large-Scale Nuclear Plants: Magnox Nuclear Power Stations 162

Maintenance

Policy and Criteria for the Recycle and Reuse of Very Low Level Contaminated Materials from Maintenance, Refurbishment and Decommissioning of Nuclear Facilities in the

\section{Managing} Federal Republic of Germany 124

Managing the Startup of the Oak Ridge Operations Environmental Restoration Program 362

Manual

A Manual for Implementing Residual Radioactive Material Guidelines 285 Marcoule

Remedial Action Costing Procedures Manual 355 Maritime

Dismantling of an Alpha Contaminated Hot Cell at the Marcoule Pilot Plant 236

Appendix A to Facility License No. NS-1 Technical Specifications and Bases (Issued as Change No. 10) for the N.S. Savannah Reactor Maritime Administration U.S. Maryland Department of Commerce, Amendment No. 7245

Results of the Indoor Radiological Survey at the W.R. Grace Company, Curtis Bay Site, Baltimore, Maryland 274

Mass

Mass Concrete Removal by High-Pressure Water Jet 208

Material

Research Program of Decommissioning Material Reuse in JAERI 108

Investigation of the Control Rod Material Presence in the TMI-2 Lower Head 130

Optimization of Measurement Techniques for Very Low Level Radioactive Waste Material 139

Study on Sorption of Tritium on Various Material Surfaces and Its Application to Decontamination of Tritium-Sorbing Materials 173

Economic Risk of Contamination Cleanup Costs Resulting from Large Nonreactor Nucle ir Material Licensee Operations 203

A Manual for Implementing Residual Radioactive Material Guidelines 285 


\section{Material}

\section{Materials}

Residual Radioactive Material Guidelines: Methodology and Applications 352

Sampling Plan for the Unconditional Release of Building Materials and Similar Large Components Encountered in Decommissioning 12

Aging Studies on Materials from the Shippingport Reactor 38

Materials Licensee Financial Assurance Guidance Related to Decommissioning: Availability 63

Radiological Protection Criteria for the Recycling of Materials from the Dismantling of Nuclear Installations Communities, Luxembourg (Luxembourg) 76

Radiological Criteria for Unrestricted Release of Materials from Nuclear Installations 77

Policy and Criteria for the Recycle and Reuse of Very Low Level Contaminated Materials from Maintenance, Refurbishment and Decommissioning of Nuclear Facilities in the Federal Republic of Germany 124

Study on Sorption of Tritium on Various Material Surfaces and Its Application to Decontamination of Tritium-Sorbing Materials 173

Aerosol Generation During Cutting of Various Materials with Plasma, Laser and Consumable Electrode 233

Compilation of Contract Research for the Materials Engineering Branch, Division of Engineering 250

Engineering Evaluation/Cost Analysis for the Proposed Removal of Contaminated Materials from Pad 1 at the Elza Gate Site, Oak Ridge, Tennessee 268

Maywood

Work Plan for the Remedial Investigation/Feasibility Study - Environmental Impact Statement for the Maywood Site, Maywood, New Jersey 269

\section{Measured}

Variation in the Annual Average Radon Concentration Measured in Homes in Mesa County, Colorado 344

\section{Measurement}

A Fast-Sorting Measurement Technique to Determine Decontamination Priority 92

Measurement and Sorting Techniques Qualified for Unrestricted Release of Metals from the Nuclear Industry 102

Optimization of Measurement Techniques for Very Low Level Radioactive Waste Material 139

Measurement and Removal of Steel Flame Cutting Aerosols (0.01-1 um) in WAGR Measurements Decommissioning Cleaning Laboratory 215

Results of Surface Activity and Radiation Field Measurements Made During Surface Decontamination Experiments Conducted at TMI-2 177

Radionuclide Source Term Measurements for Decommissioning Assessments 213 Measures

Calibration of Alpha-Track Monitors for Measurements of Thoron 342

Radon I Dwellings - Testing and Evaluation of Constructional and Buildings Services Mechanical Engineering Measures 296

Comparison Between Laser, Plasma, Waterjet, Oxygen Cutting and Other Mechanical Cutting Processes for Low Thickness (0.5 Up to $5 \mathrm{MM}) 53$ 


\section{Mechnaical}

Mechanism

Mechanical Dismantling and Breakdown Methods 190

Mechanis $n$ of Corrosion in Decontaminating Solutions of Stainless Steel and Highly Wear

Mechanisms

Resistant Hardfacing Alloys for a Liquid Metal Fast Breeder Reactor $\mathbf{1 0 0}$

Standard Format and Content Guide for Financial Assurance Mechanisms Required for Decommissioning Under 10 CFR parts 30, 40, 70, and 72 - Revision 1247

Standard Review Plan for the Review of Financial Assurance Mechanisms for Mechanochemical

Decommissioning Under 10 CFR Parts 30, 40, 70, and 72 - Revision 1248

Research and Development of LWR System Decontamination - Mechar.ochemical and

Mectings

Redox Decontamination Methods 154

Decontamination and Decommissioning of Nuclear Facilities - Final Report of Three

Mclter

Research Coordination Meetings Held Between 1984 and 1987147

Development of an Advanced Off-Gas Scrubber for an Incinerating Melter 253

Principal Components Analysis for Monitoring the West Valley Liquid Fed Ceramic Melter 262

Melting

Experience on Melting of Contaminated Steel Scrap and Treatment of Large Quantities of Low-Level Contaminated Steel for Unrestricted Release 105

Mesa

Variation in the Annual Average Radon Concentration Measured in Homes in Mesa County, Colorado 344

Mctal

Installation for Semiautomatic Air-Plasma Metal Cutting Up to $6 \mathrm{~mm}$ Thickness 62

Mechanism of Corrosion in Decontaminating Solutions of Stainless Steel and Highly Wear

Resistant Hardfacing Alloys for a Liquid Metal Fast Breeder Reactor 100

Method of Decontaminating Surface of Radioactive Metal Waste 157

30 Years of Experience with Arc Plasma Metal Cutting 267

Radium and Heavy Metal Transport Beneath an Abandoned Uranium Tailings Dam 331

Metallic

Analysis of Results Obtained with Different Cutting Techniques and Associated Filtration Systems for the Dismantling of Radioactive Metallic Components 57

Metals

Measurement and Sorting Techniques Qualified for Unrestricted Release of Metals from the Nuclear Industry 102

New Aspects in Cutting Mctals with CO2 Lasers 256

\section{Michigan}

Michigan State University TRIGA Nuclear Reactor: Order Authorizing Dismantlement of Facility and Disposition of Component Parts 140

Environmental Assessment and Finding of No Significant Impact Regarding Proposed Order

Authorizing Dismantling of the Reactor and Decomposition of Component Parts:

Michigan State University 178 


\section{Migration}

Characterization of Preferred Groundwater Migration Pathways Weldon Spring Site 23

The Migration of Grourid-Water Contaminants from Uranium Mill Tailings Piles $\mathbf{3 0 2}$

Mile

Meeting of the Advisory Panel for the Three Mile Island, Unit 2133

The TMI-2 (Three Mile Island Unit 2) Reactor Building Gross Decontamination Experiment

- Effects on Loose-Surface Contamination Levels 165

Underwater Plasma Arc Cutting in Three Mile Island's Reactor 175

GPU Nuclear Corporation: Availability of Final Supplement 3 to the Programmatic Environmental Impact Statement Related to Decontamination and Disposal of Wastes from March 28, 1979 Accident Three Mile Island Nuclear Station, Unit 2234

Milling

Biological Characterization of Radiation Exposure and Dose Estimates for Inhaled Uranium Miiling Effluents 327

Mills

Decommissioning of Uranium Mines and Mills - Canadian Regulatory Approach and Experience 341

Mine

Leachability of Radioactive Constituents from Uranium Mine Tailings 326

White King/Luck Lass Mine Remedial Action Project, Freemont National Forest, Lake County, OR 337

Mines

Contamination in Surface Waters Around Uranium Mines in the Guadiana Basin $\mathbf{3 2 5}$

Decommissioning of Uranium Mines and Mills - Canadian Regulatory Approach and Experience 341

Minimis

The Future of the de Minimis Concept 347

Mining

Plutonium Mining for Cleanup 71

Impact of Uranium Mining on the Radioactive Contamination of the Agueda River 328

Health Effects of Uranium Mining 330

Mixed

Influence of Mining Activity on Distribution of Radium in the Natural Environment $\mathbf{3 4 0}$

Decommissioning of a Mixed Oxide Fuel Fabricating Facility 75

The Decommissioning of Large and Complex Glove Box Structures in a Mixed Oxide Fuel

Fabrication Plant 93

Conversion of Mixed Waste to LSA Waste: A Case Study 293

Hazardous and Mixed Waste Management at UMTRA Sites 306

Applicable or Relevant and Appropriate Requirements (ARARs) for Radioactive Mixed Waste 364

Status Report for the Working Group on Hazardous and Mixed Waste 379

Mobilization

Mobilization and Transport of Uranium and Uranium Mill Tailings Disposal Sites $\mathbf{3 0 3}$

Model

Model Testing Conducted to Benchmark the Shippingport Reactor Pressure Vessel/Neutron

Shield Tank Safety Analysis Report for Packaging 4 
Modal

Operator Action Model in the Probabilistic Safety Study of Latina MAGNOX Nuclear Power Plant 127

A Model Study of the Water Pressure Distribution in a Crack When Impacted by a High Pressure Water Jet 174

A Process Model for West Valley Waste Vitrification 200

Model Provisions for DOE Federal Facility Agreements 378

Models

Composition Models for the Viscosity and Chemical Durability of Wesi Valley Related Nuclear Waste Glasses 112

Monitoring

The Role of Sub-Surface Contaminant Fate and Transport Models for RCRA Land Ban Regulations $\mathbf{3 6 6}$

Performance Monitoring Report for the Niagara Falls Storage Site Waste Containment Structure, Lewiston, New York, July-December, 1988 and Calendar Year 19895

Plan for Monitoring Radionuclide Emissions Other than Radon at Weldon Spring Site Critical Receptors 32

Principal Components Analysis for Monitoring the West Valley Liquid Fed Ceramic Melter 262

Monitors

Calibration of Alpha-Track Monitors for Measurements of Thoron 342

Monticello

Supcrfund Record of Decision (EPA Region 8): Monticello Vicinity Properties, Utah (First Monument

Remedial Action), September 1989 - Final Report 42

Environmental Assessment of Remedial Action at the Monument Valley Uranium Mill Multimedia Tailings Site, Monument Valley, Arizona $\mathbf{3 2 0}$

Multimedia Assessment of Health Risks for the Weldon Spring Site Remedial Action Project 13

MZFR

National

Review of Nuclear Power Plants That Have Been or Will Be Decommissioned Decommissioning Work Carried Out for KKN, FR-2, and MZFR 169

Project Plan for the Decontamination and Decommissioning of the Argonne National Laboratory Experimental Boiling Water Reactor 6

White King/Luck Lass Mine Remedial Action Project, Freemont National Forest, Lake County, OR 337

Remote Site Survey and Characterization for the National Environmental Restoration and Waste Management (ERWM) Program Using the SRIP (Solider Robot Interface Project)

Natural

Vehicle 376

Nuclear Regulation: NRC's Decommissioning Procedures and Criteria Need to Be Strengthened - Report to the Chairman, Environment, Energy, and Natural Resources Subcommittee, Committee on Government Operations, House of Representatives 121 Influence of Mining Activity on Distribution of Radium in the Natural Environment 340 


\section{NDT}

NEA

Evaluation of Structures for Decommissioning Using NDT 115

NEPA

NEA International Co-Operative Projects 189

Implementation of an Integrated CERCLA-NEPA Environmental Process at a FUSRAP Site 276

Neutron

Public Participation in the NEPA Process: Lessons Learned on the UMTRA Project 307

Model Testing Conducted to Benchmark the Shippingport Reactor Pressure Vessel/Neutron

Shield Tank Safety Analysis Report for Packaging 4

Irradiation Embrittlement of the Shippingport Neutron Shield Tank 9

Shippingport Neutron Shield Tank Sampling and Analysis Program 35

Irradiation Embrittlement Investigation of the Shippingport Station Neutron Shield Tank 36

Niagara

Performance Monitoring Report for the Niagara Falls Storage Site Waste Containment Structure, Lewiston, New York, July-December, 1988 and Calendar Year 19895

Nicderaichbach

Radiological Survey of the Niagara Falls Storage Site 17

Licensing and Surveillance of Activities for Decommissioning and Dismantling of Nuclear Nonreactor

Power Plant, Shown by the Niederaichbach Reactor as an Example 220

Economic Risk of Contamination Cleanup Costs Resulting from Large Nonreactor Nuclear Material Licensee Operations 203

Novel

The Blowdown Water Cannon - A Novel Method for Powering the Cumulation Nozzle 198 Nozzle

The Blowdown Water Cannon - A Novel Method for Powering the Cumulation Nozzle 198 NRC

Nuclear Regulation: NRC's Decommissioning Procedures and Criteria Need to $\mathrm{Be}$ Strengthened - Report to the Chairman, Environment, Energy, and Natural Resources NS

Subcommittee, Committee on Government Operations, House of Representatives 121

Appendix A to Facility License No. NS-1 Technical Specifications and Bases (Issued as Change No. 10) for the N.S. Savannah Reactor Maritime Administration U.S. Department of Commerce, Amendment No. 7245

NST

Benchmarking of the Computer Code and the Thirty-Foot Side Drop Analysis for the Shippingport RPV/NST Package 8

Nuclides

Determination of the Long-Lived Nuclides in Biological Shielding Concrete, Ion Exchange Occupational Resin and Fuel Storage Pool Water of JPDR 237

The Impact of Light-Water Reactor Decontaminations on Solidification, Waste Disposal, and Associated Occupational Exposure 226 


\section{Occupational}

The Impact of LWR Decontaminations on Solidification, Waste Disposal and Associated

Oil Occupational Exposure 227

Government Observations on the Second Report from the Committee (Session 1986-87) on Standpipe Distortion at Hinkley Point 'A' Power Station and the Cost of Decommissioning Magnox Reactors and on the Third Report (Session 1986-87) on the Ontario Effect of Oil and Gas Prices on Activity in the North Sea 144

Proposed Safeguards and Security During Future Decommissioning of Ontario Hydro's Rearitors 116

Operative

NEA International Co-Operative Projects 189

Operator

Operator Action Model in the Probabilistic Sal'ety Study of Latina MAGNOX Nuclear Power Optimization

Plant 127

Optimization of Filtering Systems for Various Concrete Decontamination Techniques 94

Study and Optimization of Filter Systems for Separating Dusts and Aerosols Produced in Layers Concrete Decontamination 95

Optimization of Measurement Techniques for Very Low Level Radioactive Waste Material 139

Ore

Extraction of Uranium, Thorium and Radium from an Elliot Lake Radioactive Ore by Chlorine-Assisted Leaching 332

Hydrochloric Acid Leaching of Üranium, Thorium, Radium and Rare-Earth Elements, from an Elliot Lake Radioactive Ore 333

\section{Organic}

OSHA

Hazardous Organic Constituents at the UMTRA Title I Sites 319

Overvicw

Transferring Generic SARA/OSHA Training to U.S. Department of Energy Facilities 394

An Overview of Waste Management Systems at the West Valley Demonstration Project 176

An Overview of Radioactive Waste Management at Sellafield 182

An Overvicw of Remedial Action Technical Information Support Activities Funded by the U.S. Department of Encrgy's Office of Environmental Restoration 350

An Overview of the Department of Energy Defense Programs Environmental Restoration Program 368

Oxide

Decommissioning of a Mixed Oxide Fucl Fabricating Facility 75

The Decommissioning of Large and Complex Glove Box Structures in a Mixed Oxide Fuel Fabrication Plant 93

Oxygen

Comparison Between Laser, Plasma, Waterjet, Oxygen Cutting and Other Mechanical

PAC Cutting Processes for Low Thickness (0.5 Up to $5 \mathrm{MM}$ ) 53

A Look at Air-PAC Machines (Plasma Arc Cutting) 263 
Package

Benchmarking of the Computer Code and the Thirty-Foot Side Drop Analysis for the Shippingport RPV/NST Package 8

Packaging

Puncture Evaluation of Shippingport Package 19

Model Testing Conducted to Benchmark the Shippingport Reactor Pressure Vessel/Neutron Shield Tank Safety Analysis Report for Packaging 4

Preliminary Studies of Packaging and Disposal of Decommissioning Waste in Switzerland 52

Paducah

Environmental Restoration and Waste Management Site Specific Plan for Oak Ridge Operation Office Paducah Gaseous Diffusion Plant 373

Palos

Surveillance of Site A and Plot M in the Palos Park Forest Preserve - 1989286

Panel

Meeting of the Advisory Panel for the Three Mile Island, Unit 2133

Participation

Particulars

Public Participation in the NEPA Process: Lessons Learned on the UMTRA Project 307

Pathway

Particulars of Regulatory Practice for Nuclear Power Plants in the German Democratic Republic 159

Standard Guide for Radioactive Pathway Methodology for Release of Sites Following

Pathways Decommissioning 229

Pavement

Characterization of Preferred Groundwater Migration Pathways Weldon Spring Site 23

Pennsylvania

Rapid Cutting of Pavement with Cavitating Water Jets 84

Verification Survey of the Shippingport Atomic Power Station, Shippingport, Pennsylvania 18

Personnel

Phase

Personnel Contamination Protection Techniques Applied During the TMI-2 Cleanup 137

Phase 1 Spring and Scep Report for the Weldon Spring Remedial Action Project, Weldon Spring, Missouri 24

Phase 2 Groundwater Quality Assessment for the Weldon Spring Site, Chemical Plant, Raffinate Pits and Surrounding Vicinity Properties 28

1990 Likely to be Critical Year for Sweden's Phase-Out Policy 126

Environmental Assessment and Finding of No Significant Impact Regarding Proposed Order Authorizing Phase 2 Dismantling of the Reactor and Disposition of Component Parts:

Piles

The University of California at Los Angeles 179

Pilot

The Migration of Ground-Water Contaminants from Uranium Mill Tailings Piles $\mathbf{3 0 2}$

REDOX Decontamination Technique Development II - REDOX Decontamination System Using Pilot Plant 119 
Pilot Piping

Dismantling of an Alpha Contaminated Hot Cell at the Marcoule Pilot Plant 236

Shippingport Station Decommissioning Project: Removal of Piping and Equipment and Removal of Primary System Components - Topical Report $\mathbf{4 4}$

Experiment on Water Jet Method Used for Cutting Concrete Which Covers Piping 156

Seismic Research on an Aged United States Gate Valve and on a Piping System in the Decommissioned Heissdampfreakior (HDR): Summary 231

Seismic Research on an Aged United States Gate Valve and on a Piping System in the Decommissioned Heissdampfreaktor (HDR): Appendices $23 \bar{z}$

Pitting

Pitting and its Control During Electropolishing of Stainless Steel 152

Plan

Proposed Plan for the Management of Bulk Wastes at the Weldon Spring Quarry, Weldon Spring, Missouri 3

Project Plan for the Decontamination and Decommissioning of the Argonne National Laboratory Experimental Boiling Water Reactor 6

Sampling Plan for the Unconditional Release of Building Materials and Similar Large Components Encountercd in Decommissioning 12

Plan for Monitoring Radionuclide Emissions Other than Radon at Weldon Spring Site Critical Receptors 32

Weldon Spring Chemical Plant Water Treatment Plan 41

West Valley Demonstration Project Community Relations Plan FY 1990/91 87

Standard Review Plan for the Review of Financial Assurance Mechanisms for Decommissioning Under 10 CFR Parts 30, 40, 70, and 72 - Revision 1248

Work Plan for the Remedial Investigation/Feasibility Study - Environmental Impact Statement for the Maywood Site, Maywood, New Jersey 269

Work Plan for the Remedial Investigation/Feasibility Study - Environmental Assessment for the Colonic Site, Colonie, New York 270

Programmatic Issues Affecting live Implementation of the DOE Five-Year Plan 367

Environmental Restoration and Waste Management: Five-Year Plan, Fiscal Years 1992-1996 370

Environmental Restoration and Waste Management Site Specific Plan for Oak Ridge Operation Office Paducah Gaseous Diffusion Plant 373

GAO's Views on DOE's Environmental Restoration and Waste Management Five-Year Plan 374

Long-Range Environmental and Waste Management Plan, Fiscal Years 1989-1995 375

Site-Directed Subsurface Environmental Initiative: Five Year Summary and Plan for Fundamental Research in Subsoils and in Groundwater, FY 1989-FY 1993380

The Hanford Reservation Environmental Restoration and Waste Management Five-Year Plan Activity Data Sheets $\mathbf{3 8 3}$

Environmental Restoration Field Office Management Plan 384

Environmental Restoration and Waste Management - Five-Year Plan 388

Applied Research, Development, Demonstration, Testing and Evaluation Plan for Environmental Restoration and Waste Management 389

Environmental Restoration Remedial Actions Program Field Office Work Plan 391

Fiscal Year 1989 Defense Waste Management and Environmental Program Plan 392 
Planned

Radiological and Chemical Characterization Report for the Planned Quarry Construction Staging Area and Water Treatment Plant: Revision 125

Planning

Nuclear Reactors Built, Being Built, or Planned - 1989246

Planning and Pregress of the WAGR Decommissioning Project 67

Remediation of Hazardous Waste Sites: Planning and Integration Requirements 359

Institutional Factors Affecting DOE Waste Management and Environmental Restoration Planning 390

Plans

Decommissioning Plans and Programs in the Federal Republic of Germany 170

Standard Guide for Nuclear Facility Decommissioning Plans 228

Standard Format and Content for Decommissioning Plans for Licensees Under 10 CFR Parts 30,40 , and 70249

Plasma

Comparison Between Laser, Plasma, Waterjet, Oxygen Cutting and Other Mechanical Cutting Processes for Low Thickness (0.5 Up to $5 \mathrm{MM}$ ) 53

Installation for Semiautomatic Air-Plasma Metal Cutting Up to $6 \mathrm{~mm}$ Thickness 62

Dismantling of JPDR Internals Gets Under Way Using Plasma Arc Cutting 149

Underwater Plasma Arc Cutting in Three Mile Island's Reactor 175

Remote Plasma Cutting on TMI Core 211

Aerosol Generation During Cutting of Various Materials with Plasma, Laser and Consumable

Electrode 233

A Look at Air-PAC Machines (Plasma Arc Cutting) 263

PLC

30 Years of Experience with Arc Plasma Metal Cutting 267

Plot

Decommissioning in British Nuclear Fuels PLC 81

Surveillance of Site A and Plot M in the Palos Park Forest Preserve - 1989286

Plutonium

Plutonium Mining for Cleanup 71

Processing at the Plutonium-Contaminated Waste Treatment Facility 191

Policy

Decontamination and Decommissioning of a Plutonium Fabrication Facility 259

Decommissioning Nuclear Power Plants: Authority and Policy Issues 64

Policy and Criteria for the Recycle and Reu ₹ of Very Low Level Contaminated Materials

from Maintenance, Refurbishment and Decommissioning of Nuclear Facilities in the

Federal Republic of Germany $1: 4$

1990 Likely to be Critical Year for Sweden's Phase-Out Policy 126

Licensing Authority Experience and Policy for Decommissioning of Nuclear Installations 164

Introducing the Geosocial Context of Nuclear Decommissioning - Policy Implications in the US and Great Britain 195

Pond

Assessment of Ash Pond Isolation Project Effectiveness 33 
Pool

Position

Determination of the I ong-Lived Nuclides in Biological Shielding Concrete, Ion Exchange Resin and Fuel Storage Pool Water of JPDR 237

Uranium Mill Facilities: Availability and Request for Public Comment on Draft Technical Powering Position on Design of Erosion Protection Covers 339 PRA

The Blowdown Water Cannon - A Novel Method for Powering the Cumulation Nozzle 198

Decontamination and Decommissioning, License Renewal, Human Factors, Generic Issues, Risk Analysis/PRA Applications, Innovative Concepts for Increased Safety of Advanced

Prediction Power Reactors 257

Thermal Aging of Some Decommissioned Reactor Components and Methodology for Life

Predictive Prediction 79

Preface

Development of QC and Predictive Leach Tests for West Valley Glasses 60

Prelude

Preface - Decontamination and Decommissioning 171

Pressure

Good Plant Practices: A Prelude to Cust Effective Decommissioning 167

Model Testing Conducted to Benchmark the Shippingport Reactor Pressure Vessel/Neutron Shield Tank Safety Analysis Report for Packaging 4

Lift of Shippingport Reactor Pressure Vessel 11

A Structural Evaluation of the Shippingport Reactor Pressure Vessel for Transport Impact Conditions 49

Development of Rock Bed Boring Machine Using Ultra-High Pressure Water 142

Adaption of High-Pressure Water Jets and Abrasives to Dismantle Nuclear Installations 172

A Model Study of the Water Pressure Distribution in a Crack When Impacted by a High Pressure Water Jet 174

Prices

Mass Concrete Removal by High-Pressure Water Jet 208

Government Observations on the Second Report from the Committee (Session 1986-87) on Standpipe Distortion at Hinkley Point 'A' Power Station and the Cost of Decommissioning Magnox Reactors and on the Third Report (Session 1986-87) on the

Primary Effect of Oil and Gas Prices on Activity in the North Sea 144

Shippingport Station Decommissioning Project: Removal of Piping and Equipment and Removal of Primary System Components - Topical Report $\mathbf{4 4}$

Summary of Work on Characterization of the Radioactive Deposits on PWR Primary Circuit Surfaces 204

Priority

A Fast-Sorting Measurement Technique to Determine Decontamination Priority $\mathbf{9 2}$ Programmatic

TMI-2: Lessons Learned by the U.S. Department of Energy - A Programmatic Perspective 218 


\section{Programmatic}

GPU Nuclear Corporation: Availability of Final Supplement 3 to the Programmatic Environmental Impact Statement Related to Decontamination and Disposal of Wastes from March 28, 1979 Accident Three Mile Island Nuclear Station, Unit 2234

\section{Programme}

Programmatic Issues Affecting the Implementation of the DOE Five-Year Plan 367

EC Starts New Research Programme 146

Proposed IAEA Programme on Safety Aspects of Nuclear Power Plant Aging and Life Extension 194

Prograns

End to Clean-up Programme in Sight (TMI-2) 251

Lecommissioning Plans and Programs in the Federal Republic of Germany 170

An Overview of the Department of Energy Defense Programs Environmental Restoration Program 368

Protection

Department of Energy Defense Programs Environmental Restoration Program Update 369

Dismantling the RB-2 Research Reactor: An Application of a Radiation Protection Approach Relevant to Italy's Decommissioning Methodology 73

Radiological Protection Criteria for the Recycling of Materials from the Dismantling of Nuclear Installations Communities, Luxembourg (Luxembourg) 76

Respiratory Protection - Lessons Learned at TMI 122

Personnel Contamination Protection Techniques Applied During the TMI-2 Cleanup 137 Radiological Protection Principles for the Decommissioning and Dismantling of Nuclear Power Plant - International Activities 216

Uranium Mill Facilities: Availability and Request for Public Comment on Draft Technical Position on Design of Erosion Protection Covers 339

EPA (Environmental Protection Agency) and State Authority Over DOE (Department of Energy) Groundwater Radionuclides 358

\section{Provisions}

Model Provisions for DOE Federal Facility Agreements 378

Pu

Public

Decommissioning of Pu Contaminated Glove Box System 193

Public Attitudes Near a Nuclear Waste Site: Survey Trends from the West Valley Demonstration Project 138

Public Participation in the NEPA Process: Lessons Learned on the UMTRA Project 307

Uranium Mill Facilities: Availability and Rey est for Public Comment on Draft Technical Puncture Position on Design of Erosion Protection Covers 339

PWR

Puncture Evaluation of Shippingport Package 19

Summary of Work on Characterization of the Radioactive Deposits on PWR Primary Circuit Surfaces 204

QC

Development of QC and Predictive Leach Tests for West Valley Glasses 


\section{Qualification}

West Valley Glass Product Qualification Durability Studies: Effects of Composition, Redox

\section{Qualificd}

State, Heat Treatment, and Groundwater 209

West Valley Strategy for Production of a Qualified Waste Form 97

Measurement and Sorting Techniques Qualified for Unrestricted Release of Metals from the Nuclear Industry 102

Quality

Phase 2 Groundwater Quality Assessment for the Weldon Spring Site, Chemical Plant, Raffinate Pits and Surrounding Vicinity Properties 28

Quarry

Graphical Quality Assurance and Data Management on the UMTRA Project $\$ 316$

Feasibility Study for Management of the Bulk Wastes at the Weldon Spring Quarry, Weldon Spring, Missouri 2

Proposed Plan for the Management of Bulk Wastes at the Weldon Spring Quarry, Weldon Spring, Missouri 3

Baseline Risk Evaluation for Exposure to Bulk Wastes at the Weldon Spring Quarry, Weldon Spring, Missouri 14

Radiological and Chemical Characterization Report for the Planned Quarry Construction Staging Area and Water. Treatment Plant: Revision 125

Remedial Investigations for Quarry Bulk Wastes 27

WSSRAP (Weldon Spring Site Remedial Action Project) Quarry Preliminary Engineering Report 30

RAAS

Weldon Spring Quarry 43

Remedial Action Assessment System (RAAS): Evaluation of Selected Feasibility Studies of CERCLA (Comprehensive Environmental Response, Compensation, and Liability Act) Hazardous Waste Sites 393

Radiation

Dismantling the RB-2 Research Reactor: An Application of a Radiation Protection Approach Relevant to Italy's Decommissioning Methodology 73

Results of Surface Activity and Radiation Field Measurements Made During Surface Decontamination Experiments Conducted at TMI-2 177

Biological Characterization of Radiation Exposure and Dose Estimates for Inhaled Uranium Milling Effluents 327

\section{Radioactivity}

Radioactivity Inventories in the Decommissioned Nuclear Power Piant 168

\section{Radiochemical}

\section{Radionuclide}

Cleanout and Decontamination of Radiochemical Hot Cells 235

Plan for Monitoring Radionuclide Emissions Other than Radon at Weldon Spring Site Critical Receptors 32

Radionuclide Correlations at TMI-2 for 10 CFR 61 Compliance 98

Radionuclide Source Term Measurements for Decommissioning Assessments 213

Radionuclide Characterization of Reactor Decommissioning Waste and Spent Fuel Assembly Hardware 214 


\section{Radionuclides}

Radionuclides in an Abandoned Reactor Facility 158

EPA (Environmental Protection Agency) and State Authority Over DOE (Department of Radium Energy) Groundwater Radionuclides 358

Dispersion of Radium-226 in a Contaminated Environment 294

Volume Estimate of Radium-Contaminated Soil in a Section of Barrows Field Park, Glen Ridge, New Jersey, November-December 1989297

Radium and Heavy Metal Transport Beneath an Abandoned Uranium Tailings Dam 331

Extraction of Uranium, Thorium and Radium from an Elliot Lake Radioactive Ore by Chlorine-Assisted Leaching 332

Hydrochloric Acid Leaching of Uranium, Thorium, Radium and Rare-Earth Elements, from an Elliot Lake Radioactive Ore 333

Radon

Influer:a of Mining Activity on Distribution of Radium in the Natural Environment $\mathbf{3 4 0}$

Evaluation of Radon Emissions and Potential Control Requirements 29

Plan for Monitoring Radionuclide Emissions Other than Radon at Weldon Spring Site Critical Receptors 32

Radon Control and Remedies in Buildings Cornwall County Council, County Architects Department, Truro, United Kingdom 295

Radon I Dwellings - Testing and Evaluation of Constructional and Buildings Services Engineering Measures 296

Variation in the Annual Average Radon Concentration Measured in Homes in Mesa County,

Raffinate Colorado. 344

Phase 2 Groundwater Quality Assessment for the Weldon Spring Site, Chemical Plant, RANDEC Raffinate Pits and Surrounding Vicinity Properties 28

Journal of the RANDEC 212

Rate

Environmental Effects on Rn-222 Fluence Rate from Reclaimed Uranium Tailings 318

Effects of Vegetation, A Clay Cap and Environmental Variables on Rn-222 Fluence Rate from Reclaimed Uranium Mill Tailings 335

RCRA

A Review of State Regulations that Exceed Those of the Federal Resource Conservation and Recovery Act (RCRA) 357

Establishing a Regulatory Framework for a RCRA (Resource, Conservation, and Recovery Act) Corrective Action Program 365

The Role of Sub-Surface Contaminant Fate and Transport Models for RCRA Land Ban Regulations 366

\section{Reactors}

Conditioning of Graphite Bricks from Dismantled Gas Cooled Reactors for Disposal 109

Proposed Safeguards and Security During Future Decommissioning of Ontario Hydro's Reactors 116

Standpipe Distortion at Hinkley Point 'A' Power Station and the Cost of Decommissioning Magnox Reactors 143 


\section{Reactors}

Government Observations on the Second Report from the Committee (Session 1986-87) on Standpipe Distortion at Hinkley Point ' $A$ ' Power Station and the Cost of Decommissioning Magnox Reactors and on the Third Report (Session 1986-87) on the Effect of Oil and Gas Prices on Activity in the North Sea 144

Nuclear Reactors Built, Being Built, or Planned - 1989246

Decontamination and Decommissioning, License Renewal, Human Factors, Generic Issues, Risk Analysis/PRA Applications, Innovative Concepts for Increased Safety of Advanced Power Reactors 257

\section{Reagents}

Inmobilization in Cement of Ion Exchange Resins Arising from the Purification of Reagents Used for the Decontamination of Reactor Circuits - Fifth Semestrial Report july-December 1988145

Receptors

Plan for Monitoring Radionuclide Emissions Other than Radon at Weldon Spring Site Critical Receptors 32

\section{Reckoning}

AGRs - The Reckoning 51

Reclaimed

Environmental Effects on Rn-222 Fluence Rate from Reclaimed Uranium Tailings $\mathbf{3 1 8}$

Effects of Vegetation, A Clay Cap and Environmental Variables on Rn-222 Fluence Rate Reclamation from Reclaimed Uranium Mill Tailings 335

Geotechnical Stability Considerations in the Design and Reclamation of Tailings Impoundments $\mathbf{3 0 0}$

Uranium Enrichment and Mill Tailings Reclamation Legislation 338

\section{Records}

Uranium Mill Tailings: Annotation of Land Records 299

Uranium Mill Tailings: Annotation of Land Records 301

Evaluation of Cleanup Levels for Remedial Action at CERCLA Sites Based on a Review of EPA Records of Decision 354

Recycle

Policy and Criteria for the Recycle and Reuse of Very Low Level Contaminated Materials from Maintenance, Refurbishment and Decommissioning of Nuclear Facilities in the Federal Republic of Germany 124

Recycling

Radiological Protection Criteria for the Recycling of Materials from the Dismantling of Nuclear Installations Cornmunities, Luxembourg (Luxembourg) 76

Redox

REDOX Decontamination Technique Development 117

REDOX Decontamination Technique Development I - Selection for Dissolutive and Regenerative Conditions 118

REDOX Decontamination Technique Development II - REDOX Decontamination System Using Pilot Plant 119

Research and Development of LWR System Decontamination - Mechanochemical and Redox Decontamination Methods 154 


\section{Redox}

Nest Valley Glass Product Qualification Durability Studies: Effects of Composition, Redox State, Heat Treatment, and Groundwater 209

\section{Reduction}

Proceedings of the U.S. Department of Energy Office of Environmental Restoration and Refurbishment Waste Management Waste Reduction Workshop 372

The Refurbishment of the D1206 Fuel Reprocessing Plant 58

Policy and Criteria for the Recycle and Reuse of Very Low Level Contaminated Materials from Maintenance, Refurbishment and Decommissioning of Nuclear Facilitics in the Regenerative Federal Republic of Germany 124

REDOX Decontamination Technique Development I - Selection for Dissolutive and Regulation Regenerative Conditions 118

Nuclear Regulation: NRC's Decommissioning Procedures and Criteria Need to Be Strengthened - Report to the Chairman, Environment, Energy, and Natural Resources Regulations

Subcommittee, Committee on Government Operations, House of Representatives 121

A Review of State Regulations that Exceed Those of the Federal Resource Conservation and Recovery Act (RCRA) 357

The Role of Sub-Surface Contaminant Fate and Transport Models for RCRA Land Ban

Regulatory Regulations 366

Draft Regulatory Guides: Issuance and Availability 69

Particulars of Regulatory Practice for Nuclear Power Plants in the German Democratic Republic 159

Regulatory Procedures for the Decommissioning of Nuclear Installations 264

Decommissioning of Uranium Mines and Mills - Canadian Regulatory Approach and Experience 341

Classification and Disposal of Radioactive Wastes: History and Legal and Regulatory Requirements 349

Information Management Systems for Integrating the Technical Data and Regulatory Requirements of Environmental Restoration Activitics 360

Strategies for Environmental Restoration in an Evolving Regulatory Environment $\mathbf{3 6 3}$

Establishing a Regulatory Framework for a RCRA (Resource, Conservation, and Recovery

Release Act) Corrective Action Program 365

Sampling Plan for the Unconditional Release of Building Materials and Similar Large Components Encountered in Decommissioning 12

Radiological Criteria for Unrestricted Relcase of Materials from Nuclear Installations 77 Measurement and Sorting Techniques Qualified for Unrestricted Release of Metals from the Nuclear Industry 102

Experience on Melting of Contaminated Steel Scrap and Treatment of Large Quantities of Low-Level Contaminated Steel for Unrestricted Release 105

Standard Guide for Radioactive Pathway Methodology for Release of Sites Following Decommissioning 229 


\section{Relcase}

\section{Remediation}

Effectiveness of Cleanup Criteria Relative to an Accident Nuclear Release 346

Remediation Through Groundwater Recovery Treatment 353

\section{Remote}

Remediation of Hazardous Waste Sites: Planning and Integration Requirements 359.

Present Status and Problems of Remote Systems Technology in Nuclear Industry 207

Remote Plasma Cutting on TMI Core 211

Remote Site Survey and Characterization for the National Environmental Restoration and Waste Management (ERWM) Program Using the SRIP (Solider Robot Interface Project)

\section{Rencwal} Vehicle 376

Decontamination and Decommissioning, License Renewal, Human Factors, Generic Issues, Risk Analysis/PRA Applications, Innovative Concepts for Increased Safety of Advanced

\section{Reprocessing} Power Reactors 257

The Refurbishment of the D1206 Fuel Reprocessing Plant 58

The Radioactive Waste Management Program Associated with the Decommissioning of the Request

Former Eurochemic Reprocessing Plant 111

Uranium Mill Facilities: Availability and Request for Public Comment on Draft Technical Reservation Position on Design of Erosion Protection Covers 339

The Hanford Reservation Environmental Restoration and Waste Management Five-Year Residual Plan Activity Data Sheets $\mathbf{3 8 3}$

Residual Radioactive Contamination from Decommissioning - Technical Basis for Translating Contamination Levels to Actual Dose - Draft Report for Comment 155

A Manual for Implementing Residual Radioactive Material Guidelines 285

Resin

Residual Radioactive Material Guidelines: Methodology and Applications 352

Determination of the Long-Lived Nuclides in Biological Shiclding Concrete, Ion Exchange

Resins

Resin and Fuel Storage Pool Water of JPDR 237

Immobilization in Cement of Ion Exchange Resins Arising from the Purification of Reagents Used for the Decontamination of Reactor Circuits - Fifth Semestrial Report July-December 1988 14:

\section{Resistant}

Mechanism of Corrosion in Decontaminating Solutions of Stainless Steel and Highly Wear Resource

Resistant Hardfacing Alloys for a Liquid Metal Fast Breeder Reactor 100

A Review of State Regulations that Exceed Those of the Federal Resource Conservation and Recovery Act (RCRA) 357

Establishing a Regulatory Framework for a RCRA (Resource, Conservation, and Recovery Act) Corrective Action Program 365 


\section{Resources}

Nuclear Regulation: NRC's Decommissioning Procedures and Criteria Need to Be Strengthened - Report to the Chairman, Environment, Energy, and Natural Resources Respiratory

Subcommittee, Commiltee on Government Operations, House of Representatives 121

\section{Response}

Respiratory Protection - Lessons Learned at TMI 122

Remedial Action Assessment System (RAAS): Evaluation of Selected Feasibility Studies of CERCLA (Comprehensive Environmental Response, Compensation, and Liability Act)

\section{Restoration} Hazardous Waste Sites 393

Department of the Army Installation Restoration Program 54

An Overview of Remedial Action Technical Information Support Activities Funded by the U.S. Department of Energy's Office of Environmental Restoration 350

Information Management Systems for Integrating the Technical Data and Regulatory Requirements of Environmental Restoration Activities 360

The Department of Energy Program for Environmental Restoration 361

Mianaging the Startup of the Oak Ridge Operations Environmental Restoration Program 362

Strategies for Environmental Restoration in an Evolving Regulatory Environment 363

An Overview of the Department of Energy Defense Programs Environmental Restoration Program 368

Department of Energy Defense Programs Environmental Restoration Program Update 369

Environmental Restoration and Waste Management: Five-Year Plan, Fiscal Years 1992-1996 370

Proceedings of the U.S. Department of Energy Office of Environmental Restoration and Waste Management Waste Reduction Workshop 372

Environmental Restoration and Waste Management Site Specific Plan for Oak Ridge Operation Office Paducah Gaseous Diffusion Plant 373

GAO's Views on DOE's Environmental Restoration and Waste Management Five-Year Plan 374

Remote Site Survey and Characterization for the National Environmental Restoration and Waste Management (ERWM) Program Using the SRIP (Solider Robot Irterface Project) Vehicle 376

Evaluation of Mid-to-Long Term Basic Research for Environmental Restoration 381

The Hanford Reservation Environmental Restoration and Waste Management Five-Year Plan Activity Data Sheets 383

Environmental Restoration Field Office Management Plan 384

Environmental Restoration and Waste Management . Five-Year Plan 388

Applied Research, Development, Demonstration, Testing and Evaluation Plan for Environmental Restoration and Waste Management 389

Institutional Factors Affecting DOE Waste Management and Environmental Restoration Planning 390

Environmental Restoration Remedial Actions Program Field Office Work Plan 391

Reuse

Research Program of Decommissioning Material Reuse in JAERI 108 


\section{Reuse}

Policy and Criteria for the Recycle and Reuse of Very Low Level Contaminated Materials from Maintenance, Refurbishment and Decommissioning of Nuclear Facilities in the

Revicw Federal Republic of Germany 124

Review of Nuclear Power Plants That Have Been or Will Be Decommissioned Decommissioning Work Carried Out for KKN, FR-2, and MZFR 169

A Review of Plant Decontamination Methods: 1988 Update 210

Standard Review Plan for the Review of Financial Assurance Mechanisms for Decommissioning Under 10 CFR Parts 30, 40, 70, and 72 - Revision 1248

Evaluation of Cleanup Levels for Remedial Action at CERCLA Sites Bas d on a Review of EPA Records of Decision 354

A Review of State Regulations that Exceed Those of the Federal Resource Conservation and Recovery Act (RCRA) 357

Comparative Revicw of U.S. Department of Energy CERCLA Federal Facility Agreements 377

Rifle

Remedial Actions at the Former Union Carbide Corporation Uranium Mill Sites, Rifle, Garficld County, Colorado - Final Environmental Impact Statement, Volume I: Text 321

Remedial Actions at the Former Union Carbide Corporation Uranium Mill Sites, Rifle, Garficld County, Colorado - Final Environmental Impact Statement, Volume II: Appendices 322

Risk

Bascline Risk Evaluation for Exposure to Bulk Wastes at the Weldon Spring Quarry, Weldon Spring, Missouri 14

The Risk Assessment of Environmental and Human Hazards 34

Economic Risk of Contamination Clcanup Costs Resulting from Large Nonreactor Nuclear Material Licensec Operations 203

Decontamination and Decommissioning, License Renewal, Human Factors, Generic Issues, Risk Analysis/PRA Applications, Innovative Concepts for Increased Safety of Advanced Power Reactors 257

Risks

Multimedia Assessment of Health Risks for the Weldon Spring Site Remedial Action Project 13

River

Impact of Uranium Mining on the Radioactive Contamination of the Agueda River 328

$\mathbf{R n}$

Environmental Effects on Rn-222 Fluence Rate from Reclaimed Uranium Tailings 318

Effects of Vegetation, A Clay Cap and Environmental Variables on Rn-222 Fluence Rate from Reclaimed Uranium Mill Tailings 335

Robot

Conceptual Design for a Land Decontamination Robot 266

Remote Site Survey and Characterization for the National Environmental Restoration and Waste Management (ERWM) Program Using the SRIP (Solider Robot Interface Project) Vehicle 376 


\section{Rock}

Rod

Development of Rock Bed Boring Machine Using Ultra-High Pressure Water 142

Investigation of the Control Rod Material Presence in the TMI-2 Lower Head 130

RPV

Benchmarking of the Computer Code and the Thirty-Foot Side Drop Analysis for the Shippingport RPV/NST Package 8

Rules

Safeguards

The Rules Changed 304

Proposed Safeguards and Security During Future Decommissioning of Ontario Hydro's Reactors 116

Safety

Model Testing Conducted to Benchmark the Shippingport Reactor Pressure Vessel/Neutron Shield Tank Safety Analysis Report for Packaging 4

NPP Safety Problems 50

Operator Action Model in the Probabilistic Safety Study of Latina MAGNOX Nuclear Power

Plant 127

Radiological Safety Aspects of Decontamination Methods - Decontamination Method Applied in the Decommissioning of the Gundremmingen Nuclear Power Station 163

Proposed IAEA Programme on Safety Aspects of Nuclear Power Plant Aging and Life Extension 194

Decontamination and Decommissioning, License Renewal, Human Factors, Generic Issues, Risk Analysis/PRA Applications, Innovative Concepts for Increased Safety of Advanced Power Reactors 257

Radiological Surveillances and Health and Safety Audits at UMTRA Sites 305

Durango Health and Safety Audit 311

UMTRA Project Environmental, Health and Safety Audit Checklist 312

Environment, Safety, and Health Needs of the U.S. Department of Encrgy - Volume 2: Site Summaries 385

Environment, Safety and Health Report for the Department of Energy Defense Complex: Executive Summary 386

Environment, Safety and Health Report for the Department of Energy Defense Complex 387

Sampling

Sampling Plan for the Unconditional Release of Building Materials and Similar Large Components Encountered in Decommissioning 12

SARA

Shippingport Neutron Shicld Tank Sampling and Analysis Program 35 Savannah

Transferring Generic SARA/OSHA T aining to U.S. Department of Encrgy Facilities 394

Appendix A to Facility License No. NS-1 Technical Specifications and Bases (Issued as Change No. 10) for the N.S. Savannah Reactor Maritime Administration U.S. Department of Commerce, Amendment No. 7245 


\section{Science}

The Community's Research and Development Program on Radioactive Waste Management and Storage, Shared Cost Action - Nuclcar Science and Technology Series: Annual Progress Report 83

Scrap

Experience on Melting of Contaminated Stcel Scrap and Treatment of Large Quantities of Low-Level Contaminated Stecl for Unrestricted Release 105

\section{Scrubbcr}

Development of an Advanced Off-Gas Scrubber for an Incinerating Melter 253

Sca

Government Observations on the Second Report from the Committee (Session 1986-87) on Standpipe Distortion at Hinkley Point 'A' Power Station and the Cost of Decommissioning Magnox Rcactors and on the Third Report (Session 1986-87) on the Security Effect of Oil and Gas Prices on Activity in the North Sea 144

Proposed Safeguards and Security During Future Decommissioning of Ontario Hydro's Reactors 116

Scep

Phase 1 Spring and Seep Report for the Weldon Spring Remedial Action Project, Weldon Spring, Missouri 24

Secpage

Geochemical Aspects of Seepage from Mill Tailings 313

Scismic

Lead Isotopes as Secpage Indicators Around a Uranium Tailings Dam 329

Seismic Research on an Aged United States Gate Valve and on a Piping System in the Decommissioned Heissdampfreaktor (HDR): Summary 231

Seismic Research on an Aged United States Gate Valve and on a Piping System in the Decommissioned Heissdampfreaktor (HDR): Appendices 232

Sellaficld

An Dverview of Radioactive Waste Management at Sellaficld 182

\section{Semiautomatic}

Decommissioning at Sellafield $\mathbf{2 2 3}$

Scparating

Installation for Semiautomatic Air-Plasma Metal Culting Up to $6 \mathrm{~mm}$ Thickness 62

Study and Optimization of Filter Systems for Separating Dusts and Aerosols Produced in Scassion Layers Concrete Decontamination 95

Government Observations on the Second Report from the Committee (Session 1986-87) on Standpipe Distortion at Hinkley Point 'A' Power Station and the Cost of Decommissioning Maģnox Reactors and on the Third Report (Session 1986-87) on the Effect of Oil and Gas Prices on Activity in the North Sea 144

Sewer

Sheets

Gamma and Beta Logging of Underground Sewer and Process Lines 343

The Hanford Reservation Environmental Restoration and Waste Management Five-Year Plan Activity Data Sheets 383; 


\section{Shield}

Model Testing Conducted to Benchmark the Shippingport Reactor Pressure Vessel/Neutron Shield Tank Safety Analysis Report for Packaging 4

Irradiation Embrittlement of the Shippingport Neutron Shield Tank 9

Shippingport Neutron Shield Tank Sampling and Analysis Program 35

Irradiation Embrittlement Investigation of the Shippingport Station Neutron Shield Tank 36

Research and Development of a Machine for the Removing System of Biological Shield Wall of a Nuclear Reactor 120

\section{Shiclding}

Determination of the Long-Lived Nuclides in Biological Shiclding Concrete, Ion Exchange

Resin and Fuel Storage Pool Water of JPDR 237

\section{Shippingport}

Shippingport Station Aging Evaluation 1

Model Testing Conducted to Benchmark the Shippingport Reactor Pressure Vessel/Neutron

Shield Tank Safety Analysis Report for Packaging 4

Benchmarking of the Computer Code and the Thirty-Foot Side Drop Analysis for the

Shippingport RPV/NST Package 8

Irradiation Embrittlement of the Shippingport Neutron Shield Tank 9

Lift of Shippingport Reactor Pressure Vessel 11

Decommissioning of the Shippingport Atomic Power Station 16

Verification Survey of the Shippingport Atomic Power Station, Shippingport, Pennsylvania 18

Puncture Evaluation of Shippingport Package 19

Shippingport Neutron Shield Tank Sampling and Analysis Program 35

Irradiation Embrittlement Investigation of the Shippingport Station Neutron Shield Tank 36

Completion of Shippingport Reactor Decommissioning 37

Aging Studies on Materials from the Shippingport Reactor 38

Shippingport Station Decommissioning Project: Removal of Piping and Equipment and Removal of Primary System Components - Topical Report $\mathbf{4 4}$

Shippingport Station Decommissioning Project: Activity Specification 12 - Decontamination, Topical Report $\mathbf{4 5}$

Shippingport Station Decommissioning Project: Removal of Structures and Containment Chambers - Topical Report 46

Shippingport Station Decommissioning Project - Final Project Report 47

Shippingport Station Decommissioning Project - FY 1989 Annual Progress Report 48

A Structural Evaluation of the Shippingport Reactor Pressure Vessel for Transport Impact Conditions 49

\section{Significant}

Environmental Assessment and Finding of No Significant Impact Regarding Proposed Order Authorizing Dismantling of the Reactor and Decomposition of Component Parts: Michigan State University 178

Environmental Assessment and Finding of No Significant Impact Regarding Proposed Order Authorizing Phase 2 Dismantling of the Reactor and Disposition of Component Parts: The University of California at Los Angeles 179 
Significant Simulated

Environmental Assessment and Finding of No Significant Impact Regarding Proposed Order Authorizing Dismantling of the Reactor and Decomposition of Component Parts 258 Sizewell

Crystallization Behavior of a Fully Simulated West Valley Borosilicate Glass 151

Decommissioning at Ground Level - Sizewell and the Uncertainties of Faith 196

Soil

Volume Estimate of Radium-Contaminated Soil in a Section of Barrows Field Park, Glen Ridge, New Jersey, November-December 1989297

A Field Study Designed to Select the In-Situ Instrument Most Useful for Estimating Uranive Contamination in Soil 348

Solider

Remote Site Survey and Characterization for the National Environmental Restoration and Waste Management (ERWM) Program Using the SRIP (Solider Robot Interface Project)

Solidification Vehicle 376

The Impact of Light-Water Reactor Decontaminations on Solidification, Waste Disposal, and Associated Occupational Exposure 226

The Impact of LWR Decontaminations on Solidification, Waste Disposal and Associated Solutions Occupational Exposure 227

Mechanism of Corrosion in Decontaminating Solutions of Stainless Steel and Highly Wear Sorbing Resistant Hardfacing Alloys for a Liquid Metal Fast Breeder Reactor $\mathbf{1 0 0}$

Study on Sorption of Tritium on Various Material Surfaces and Its Application to Sorption Decontamination of Tritium-Sorbing Materials 173

Study on Sorption of Tritium on Various Material Surfaces and Its Application to Sorting Decontamination of Tritium-Sorbing Materials 173

A Fast-Sorting Muasurement Technique to Determine Decontamination Priority $\mathbf{9 2}$

Measurement and Sorting Techniques Qualified for Unrestricted Release of Metals from the Specification Nuclear Industry 102

Shippingport Station Decommissioning Project: Activity Specification 12 - Decontamination, Specifications Topical Report 45

Appendix A to Facility License No. NS-1 Technical Specifications and Bases (Issued as Change No. 10) for the N.S. Savannah Reactor Maritime Administration U.S. SRIP Department of Commerce, Amendment No. 7245

Remote Site Survey and Characterization for the National Environmental Restoration and Waste Management (ERWM) Program Using the SRIP (Solider Robot Interface Project) Vehicle 376 
Stability

Geotechnical Stability Considerations in the Design and Reclamation of Tailings Impoundments $\mathbf{3 0 0}$

Stack

Decommissioning a 60-M-Tall Exhaust Stack 20

Staging

Radiological and Chemical Characterization Report for the Planned Quarry Construction

Stainless

Staging Area and Water Treatment Plant: Revision 125

Mechanism of Corrosion in Decontaminating Solutions of Stainiess Steel and Highly Wear

Resistant Hardfacing Alloys for a Liquid Metal Fast Breeder Reactor 100

Chemical Decontamination Method for Stainless Steel 136

Standard

Pitting and its Control During Electropolishing of Stainless Steel 152

Standard Guide for Nuclear Facility Decommissioning Plans 228

Standard Guide for Radioactive Pathway Methodology for Release of Sites Following Decommissioning 229

Standard Format and Content Guide for Financial Assurance Mechanisms Required for

Decommissioning Under 10 CFR parts 30, 40, 70, and 72 - Revision 1247

Standard Review Plan for the Revicw of Financial Assurance Mechanisms for Decommissioning Under 10 CFR Parts 30, 40, 70, and 72 - Revision 1248

Standard Format and Content for Decommissioning Plans for Licensees Under 10 CFR Parts 30,40 , and 70249

\section{Standpipe}

Standpipe Distortion at Hinkley Point 'A' Power Station and the Cost of Decommissioning Magnox Reactors 143

Government Observations on the Second Report from the Committee (Session 1986-87) on Standpipe Distortion at Hinkley Point 'A' Power Station and the Cost of Decommissioning Magnox Reactors and on the Third Report (Session 1986-87) on the Effect of Oil and Gas Prices on Activity in the North Sea 144

Startup

Managing the Startup of the Oak Ridge Operations Environmental Restoration Program 362

Stations

Decommissioning of Nuclear Power Stations 125

Factors Influencing the Decommissioning of Large-Scale Nuclear Plants: Magnox Nuclear Power Stations 162

Estimated Doses from Decommissioning Activities at Commercial Nuclear Power Stations 187

Status

Status of the Decontamination and Decommissioning of the Experimental Boiling Water Reactor (EBWR) 7

Present Status and Problems of Remote Systems Technology in Nuclear Industry 207

Annual Status Report on the Uranium Mill Tailings Remedial Action Program 323

Annual Status Report on the Uranium Mill Tailings Remedial Action Program 324

Status Report for the Working Group on Hazardous and Mixed Waste 379 
Stecl

Mechanism of Corrosion in Decontaminating Solutions of Stainless Steel and Highly Wear Resistant Hardfacing Alloys for a Liquid Metal Fast Breeder Reactor 100

Experience on Melting of Contaminated Steel Scrap and Treatment of Large Quantities of Low-Level Contaminated Steel for Unrestricted Release 105

Submerged Cutting of Steel by Abrasive Water Jets 129

Chemical Decontamination Method for Stainless Steel 136

Pitting and its Control During Electropolishing of Stainless Steel 152

The Use of the Deep Kerfer for Thick, Steel-Reinforced Concrete Cutting 202

Measurement and Removal of Steel Flame Cutting Aerosols (0.01-1 um) in WAGR

Storage Decommissioning Cleaning Laboratory 215

Performance Monitoring Report for the Niagara Falls Storage Site Waste Containment Structure, Lewiston, New York, July-December, 1988 and Calendar Year 19895

Radiological Survey of the Niagara Falls Storage Site 17

Temporary Storage Area Characterization Report 26

The Community's Research and Development Program on Radioactive Waste Management and Storage, Shared Cost Action - Nuclear Science and Technology Series: Annual Progress Report 83

Determination of the Long-Lived Nuclides in Biological Shielding Concrete, Ion Exchange Resin and Fuel Storage Pool Water of JPDR 237

Verification of 1988 Remedial Actions, Vicinity Properties, Colonie Interim Storage Site, Colonie, New York 272

Verification Surveys of Non-Designated Vicinity Properties, Colonie Interim Storage Site, Colonie, NY 273

Strategies

Strategies for Environmental Restoration in an Evolving Regulatory Environment 363

Stress Structural

Heat Stress Control in the ГMI-2 Defueling and Decontamination Activities 219

A Structural Evaluation of the Shippingport Reactor Pressure Vessel for Transport Impact Conditions 49

\section{Structure}

Demolition of Structural Concrete Containing Unbonded Tendons 261

Performance Monitoring Report for the Niagara Falls Storage Site Waste Containment Structure, Lewiston, New York, July-December, 1988 and Calendar Year 19895 Structures

Shippingport Station Decommissioning Project: Removal of Structures and Containment Chambers - Topical Report 46

The Decommissioning of Large and Complex Glove Box Structures in a Mixed Oxide Fuel Fabrication Plant 93

Explosive Techniques for the Dismantling of Radioactive Concrete Structures 114

Subcommittce

Evaluation of Structures for Decommissioning Using NDT 115

Nuclear Regulation: iNRC's Decommissioning Procedures and Criteria Need to Be Strengthened - Report to the Chairman, Environment, Energy, and Natural Resources Subcommittee, Committee on Government Operations, House of Representatives 121 


\section{Submerged}

\section{Subsoils}

Submerged Cutting of Steel by Abrasive Water Jets 129

Site-Directed Subsurface Environmental Initiative: Five Year Summary and Plan for Fundamental Research in Subsoils and in Groundwater, FY 1989-FY 1993380

\section{Summary}

TMI-2 Defuelling Conditions and Summary of Research Findings 96

Summary of Work on Characterization of the Radioactive Deposits on PWR Primary Circuit Surfaces 204

Seismic Research on an Aged United States Gate Valve and on a Piping System in the Decommissioned Heissdampfreaktor (HDR): Summary 231

Site-Directed Subsurface Environmental Initiative: Five Year Summary and Plan for Fundamental Research in Subsoils and in Groundwater, FY 1989-FY 1993380

Environment, Safety and Health Report for the Department of Energy Defense Complex:

Superfund Executive Summary 386

Superfund Record of Decision (EPA Region 8): Monticello Vicinity Properties, Utah (First Remedial Action), September 1989 - Final Report 42

\section{Supernatant}

\section{Surface}

Construction and Cold Testing of the West Valley Supernatant Treatment System 68

Method of Decontaminating Surface of Radioactive Metal Waste 157

The TMI-2 (Three Mile Island Unit 2) Reactor Building Gross Decontamination Experiment

- Effects on Loose-Surface Contamination Levels 165

Results of Surface Activity and Radiation Field Measurements Made During Surface

Decontamination Experiments Conducted at TMI-2 177

Thermal Techniques for Surface Concrete Decontamination 183

Contamination in Surface Waters Around Uranium Mines in the Guadiana Basin 325

The Role of Sub-Surface Contaminant Fate and Transport Models for RCRA Land Ban Regulations 366

\section{Surfaces}

Study on Sorption of Tritium on Various Material Surfaces and Its Application to Decontamination of Tritium-Sorbing Materials 173

Summary of Work on Characterization of the Radioactive Deposits on PWR Primary Circuit Surfaces 204

\section{Surveillance}

Licensing and Surveillance of Activities for Decommissioning and Dismantling of Nuclear

Power Plant, Shown by the Niederaichbach Reactor as an Example 220

Surveillance of Site A and Plot M in the Palos Park Forest Preserve - 1989286

Radiological Surveillance of Remedial Action Activities at the Processing Site - Durango,

Colorado, May 16-18, 1989309

\section{Surveillances}

Radiological Surveillances and Health and Safety Audits at UMTRA Sites 305

Guidelines for Conducting Radiological Surveillances of Remedial Action Activities at UMTRA Processing Sites $\mathbf{3 1 0}$ 
Surveys

Verification Surveys of Non-Designated Vicinity Properties, Colonie Interim Storage Site, Colonie, NY 273

Systems

Development of Bagless Transfer Systems at British Nuclear Fuels Limited (BNFL) 56

Analysis of Results Obtained with Different Cutting Techniques and Associated Filtration Systems for the Dismantling of Radioactive Metallic Components 57

Optimization of Filtering Systems for Various Concrete Decontamination Techniques 94

Study and Optimization of Filter Systems for Separating Dusts and Aerosols Produced in Layers Concrete Decontamination 95

An Overview of Waste Management Systems at the West Valley Demonstration Project 176

Present Status and Problems of Remote Systems Technology in Nuclear Industry 207

Waterjet Cutting: Systems Offer Versatility 254

Verification of Remedial Action on Ventilation Systems, Jones Chenical Laboratory, University of Chicago, Chicago, Illinois 287

Information Management Systems for Integrating the Technical Data and Regulatory Requirements of Environmental Restoration Activities $\mathbf{3 6 0}$

Tables

Management Information Systems for Environmental Compliance Activities 382

Radiological Characterization Report for FUSRAP Properties in the St. Louis, Missouri, Area - Volume II: Data Tables 290

Radiological Characterization Report for FUSRAP Properties in the St. Louis, Missouri, Area - Volume III: Data Tables (continued) 291

Tank

Model Testing Conducted to Benchmark the Shippingport Reactor Pressure Vessel/Neutron Shield Tank Safety Analysis Report for Packaging 4

Irradiation Embrittlement of the Shippingport Neutron Shield Tank 9

Shippingport Neutron Shield Tank Sampling and Analysis Program 35

Irradiation Embrittlement Investigation of the Shippingport Station Neutron Shield Tank 36

Technologies

Technology

Cost Estimate Guidelines for Advanced Nuclear Power Technologies 90

Why It Is Important Not to Get too Carried Away with the Technology (Reactor Decommissioning) 72

The Community's Research and Development Program on Radioactive Waste Management and Storage, Shared Cost Action - Nuclear Science and Technology Series: Annual Progress Report 83

Decontamination and Decommissioning Technology Development of Nuclear Facilities 192 Temperature

Present Status and Problems of Remote Systems Technology in Nuclear Industry 207

Temporary

Very Soft Works at Room Temperature 135

Tendons

Temporary Storage Area Characterization Report 26

Demolition of Structural Concrete Containing Unbonded Tendons 261 
Thermal

Ventilation and Filtration Techniques for Handling Aerosols Produced by Thermal Cutting Operations 65

Thermal Aging of Some Decommissioned Reactor Components and Methodology for Life Prediction 79 Thickness

Thermal Techniques for Surface Concrete Decontamination 183

Comparison Between Laser, Plasma, Waterjet, Oxygen Cutting and Other Mechanical Cutting Processes for Low Thickness (0.5 Up to $5 \mathrm{MM}$ ) 53

Thorium

Installation for Semiautomatic Air-Plasma Metal Cutting Up to $6 \mathrm{~mm}$ Thickness 62

Extraction of Uranium, Thorium and Radium from an Elliot Lake Radioactive Ore by Chlorine-Assisted Leaching 332

Hydrochloric Acid Leaching of Uranium, Thorium, Radium and Rare-Earth Elements, from an Elliot Lake Radioactive Ore 333

\section{Thoron}

TMI

Calibration of Alpha-Track Monitors for Measurements of Thoron 342

TMI-2 Defuelling Conditions and Summary of Research Findings 96

Radionuclide Correlations at TMI-2 for 10 CFR 61 Compliance 98

Respiratory Protection - Lessons Learned at TMI 122

Investigation of the Control Rod Material Presence in the TMI-2 Lower Head 130

Personnel Contamination Protection Techniques Applied During the TMI-2 Cleanup 137

The TMI-2 (Three Mile Island Unit 2) Reactor Building Gross Decontamination Experiment - Effects on Loose-Surface Contamination Levels 165

Results of Surface Activity and Radiation Field Measurements Made During Surface Decontamination Experirnents Conducted at TMI-2 177

Remote Plasma Cutting on TMI Core 211

TMI-2: Lessons Learned by the U.S. Department of Energy - A Programmatic Perspective 218

Heat Stress Control in the TMJ-2 Defueling and Decontamination Activities 219

Tokai

End to Clean-up Programme in Sight (TMI-2) 251

State of Dismantling Reactor Facilities (JPDR) in Tokai Research Establishment, Japan Atomic Energy Research Institute 221

Track

Calibration of Alpha-Track Monitors for Measurements of Thoron 342

Training Transfer

Transferring Generic SARA/OSHA Training to U.S. Department of Energy Facilities 394

Final Report: Decontamination and Decommissioning of Heat Transfer Reactor Experiment

Test Assemblies HTRE-2 and HTRE-3 22

Transferring

Development of Bagless Transfer Systems at British Nuclear Fucls Limited (BNFL) 56

Transferring Generic SARA/OSHA Training to U.S. Department of Energy Facilities 
Translating

Residual Radioactive Contamination from Decommissioning - Technical Basis for Translating Contamination Levels to Actual Dose - Draft Report for Comment 155

Transport

A Structural Evaluation of the Shippingport Reactor Pressure Vessel for Transport Impact Conditions 49

Mobilization and Transport of Uranium and Uranium Mill Tailings Disposal Sites 303

Radium and Heavy Metal Transport Beneath an Abandoned Uranium Tailings Dam 331

The Role of Sub-Surface Contaminant Fate and Transport Models for RCRA Land Ban Regulations 366

Trends

Public Attitudes Near a Nuclear Waste Site: Survey Trends from the West Valley Demonstration Project 138

TRIGA

\section{Tritium}

Michigan State University TRIGA Nuclear Reactor: Order Authorizing Dismantlement of Facility and Disposition of Component Parts 140

Study on Sorption of Tritium on Various Material Surfaces and Its Application to Decontamination of Tritium-Sorbing Materials 173

Truro

Radon Control and Remedies in Buildings Cornwall County Council, County Architects Department, Truro, United Kingdom 295

um Measurement and Removal of Steel Flame Cutting Aerosols (0.01-1 um) in WAGR Decommissioning Cleaning Laboratory 215

UMTRA

Radiological Surveillances and Health and Safety Audits at UMTRA Sites 305

Hazardous and Mixed Waste Management at UMTRA Sites 306

Public Participation in the NEPA Process: Lessons Learned on the UMTRA Project 307

Guidelines for Conducting Radiological Surveillances of Remedial Action Activities at

UMTRA Processing Sites $\mathbf{3 1 0}$

UMTRA Project Environmental, Health and Safety Audit Checklist 312

Progress on the UMTRA Project: The Role of the Inclusion Survey Contractor 315

Graphical Quality Assurance and Data Management on the UMTRA Project 316

\section{Unbonded}

Hazardous Organic Constituents at the UMTRA Title I Sites 319

Demolition of Structural Concrete Containing Unbonded Tendons 261

\section{Uncertainties}

Decommissioning at Ground Level - Sizewell and the Uncertainties of Faith 196

Unconditional

Sampling Plan for the Unconditional Release of Building Materials and Similar Large

\section{Underground}

Components Encountered in Decommissioning 12

Gamma and Beta Logging of Underground Sewer and Process Lines 343

Underwater

Underwater Arc Cutting with a Cored Electrode 88

Underwater Plasma Arc Cutting in Threc Mile Island's Reactor 175 
Union

Remedial Actions at the Former Union Carbide Corporation Uranium Mill Sites, Rifle, Garfield County, Colorado - Final Environmental Impact Statement, Volume I: Text 321

Remedial Actions at the Former Union Carbide Corporation Uranium Mill Sites, Rifle, Garfield County, Colorado - Final Environmental Impact Statement, Volume II:

Unrestricted Appendices 322

Radiological Criteria for Unrestricted Release of Materials from Nuclear Installations 77

Measurement and Sorting Techniques Qualified for Unrestricted Release of Metals from the Nuclear Industry 102

Experience on Melting of Contaminated Steel Scrap and Treatment of Large Quantities of Low-Level Contaminated Steel for Unrestricted Release 105

Useful

A Field Study Designed to Select the In-Situ Instrument Most Useful for Estimating Uranium Contamination in Soil 348

Utah

Superfund Record of Decision (EPA Region 8): Monticello Vicinity Properties, Utah (First Utilities Remedial Action), September 1989 - Final Report 42

Experience Gained with the Decommissioning of Nuclear Power Plant Operated by the Utilizable Federal German Electric Utilities 255

Valve

Installation Dismantling System, Working Process and Hood Utilizable in this Systern 205

Seismic Research on an Aged United States Gate Valve and on a Piping System in the Decommissioned Heissdampfreaktor (HDR): Summary 231

Seismic Research on an Aged United States Gate Valve and on a Piping System in the Variables Decommissioned Heissdampfreaktor (HDR): Appendices 232

Effects of Vegetation, A Clay Cap and Environmental Variables on Rn-222 Fluence Rate Vegetation from Reclaimed Uranium Mill Tailings 335

Effects of Vegetation, A Clay Cap and Environmental Variables on Rn-222 Fluence Rate Vehicle from Reclaimed Uranium Mill Tailings 335

Remote Site Survey and Characterization for the National Environmental Restoration and Waste Management (ERWM) Program Using the SRIP (Solider Robot Interface Pr : ect) Vehicle 376

\section{Ventilation}

Ventilation and Filtration Techriques for Handling Aerosols Produced by Thermal Cutting Operations 65

Verification of Remedial Action on Ventilation Systems, Jones Chemical Laboratory, Versatility University of Chicago, Chicago, Illinois 287

Waterjet Cutting: Systems Offer Versatility 254 
Vessel

Model Testing Conducted to Benchmark the Shippingport Reactor Pressure Vessel/Neutron Shield Tank Safety Analysis Report for Packaging 4

Lift of Shippingport Reactor Pressure Vessel 11

A Structural Evaluation of the Shippingport Reactor Pressure Vessel for Transport Impact Conditions 49

Viscosity

Composition Models for the Viscosity and Chemical Durability of West Valley Related Nuclear Waste Glasses 112

Vital

Determination of Ecologically Vital Groundwaters at Selected Sites in the Formerly Utilized Sites Remedial Action Program 292

Vitrification

Three Year's Progress of the West Valley Demonstration Project Vitrification System 61 Volumes

A Process Model for West Valley Waste Vitrification 200 WAGR

Analysis of Radiological Survey Data to Determine Contaminated Waste Volumes 351

Planning and Progress of the WAGR Decommissioning Project 67

Measurement and Removal of Steel Flame Cutting Aerosols (0.01-1 um) in WAGR Decommissioning Cleaning Laboratory 215

Wall

Research and Development of a Machine for the Removing System of Biological Shield Wall of a Nuclear Reactor 120

Water

Project Plan for the Decontamination and Decommissioning of the Argonne National Laboratory Experimental Boiling Water Reactor 6

Status of the Decontamination and Decommissioning of the Experimental Boiling Water Reactor (EBWR) 7

Engineering Evaluation/Cost Analysis for the Proposed Management of Contaminated Water Impounded at the Weldon Spring Chemical Plant Area 21

Radiological and Chemical Characterization Report for the Planned Quarry Construction Staging Area and Water Treatment Plant: Revision 125

Weldon Spring Chemical Plant Water Treatment Plan 41

Rapid Cutting of Pavement with Cavitating Water Jets 84

Submerged Cutting of Steel by Abrasive Water Jets 129

Development of Rock Bed Boring Machine Using Ultra-High Pressure Water 142

Experiment on Water Jet Method Used for Cutting Concrete Which Covers Piping 156

Adaption of High-Pressure Water Jets and Abrasives to Dismantle Nuclear Installations 172

A Model Study of the Water Pressure Distribution in a Crack When Impacted by a High

Pressure Water Jet 174

The Blowdown Water Cannon - A Novel Method for Powering the Cumulation Nozzle 198 Mass Concrete Removal by High-Pressure Water Jet 208

The Impact of Light-Water Reactor Decontaminations on Solidification, Waste Disposal, and Associated Occupational Exposure 226

Determination of the Long-Lived Nuclides in Biological Shielding Concrete, Ion Exchange

Resin and Fuel Storage Pool Water of JPDR 237 
Water Waterjat

The Migration of Ground-Water Contaminants from Uranium Mill Tailings Piles $\mathbf{3 0 2}$

Comparison Between Laser, Plasma, Waterjet, Oxygen Cutting and Other Mechanical Cutting Processes for Low Thickness (0.5 Up to $5 \mathrm{MM}$ ) 53

Comparing Laser and Waterjet Cutting 184

Waterjets

Waterjet Cutting: Systems Offer Versatility 254

Waters

Cutting with Abrasive Waterjets 131

Cutting with Abrasive Waterjets 132

Wear

Contamination in Surface Waters Around Uranium Mines in the Guadiana Basin 325

Mechanism of Corrosion in Decontaminating Solutions of Stainless Steel and Highly Wear Weldon Resistant Hardfacing Alloys for a Liquid Metal Fast Breeder Reactor 100

Feasibility Study for Management of the Bulk Wastes at the Weldon Spring Quarry, Weldon Spring, Missouri 2

Proposed Plan for the Management of Bulk Wastes at the Weldon Spring Quarry, Weldon Spring, Missouri 3

Multimedia Assessment of Health Risks for the Weldon Spring Site Remedial Action Project 13

Baseline Risk Evaluation for Exposure to Bulk Wastes at the Weldon Spring Quarry, Weldon Spring, Missouri 14

Engineering Evaluation/Cost Analysis for the Proposed Management of Contaminated Water Impounded at the Weldon Spring Chemical Plant Area 21

Characterization of Preferred Groundwater Migration Pathways Weldon Spring Site 23

Phase 1 Spring and Seep Report for the Weldon Spring Remedial Action Project, Weldon Spring, Missouri 24

Phase 2 Groundwater Quality Assessment for the Weldon Spring Site, Chemical Plant, Raffinate Pits and Surrounding Vicinity Properties 28

WSSRAP (Weldon Spring Site Remedial Action Project) Quarry Preliminary Engineering Report 30

Buildings Radiological Characterization Report for the Weidon Spring Site Remedial Action Project, Weldon Spring, Missouri 31

Plan for Monitoring Radionuclide Emissions Other than Radon at Weldon Spring Site Critical Receptors 32

Environmental Compliance Assessment Findings for Wcldon Spring Site Remedial Action Program 40

Weldon Spring Chemical Plant Water Treatment Plan 41

White

Weldon Spring Quarry 43

White King/Luck Lass Mine Remedial Action Project, Freemont National Forest, Lake County, OR 337

\section{Windscale}

The Windscale Advanced Gas-Cooled Reactor Stage 3 Decommissioning Project 243 


\section{Worked}

Contact Arc Cutting of Worked-Out Equipment 186

Working

Installation Dismantling. Systcm, Working Process and Hood Utilizable in this System 205

Status Report for the Working Groun on Irazardous and Mixed Waste 379

Works

World

Very Soft Works at Room Temperature 135

Coping with the Biggest Dismantling Project in the World - Reactor Decommissioning 15 WSSRAP

WSSRAP (Weldon Spring Site Remedial Action Project) Quarry Preliminary Engineering Report 30 
$253 / 254$

PUBLICATION DESCRIPTION INDEX 
AEEW-M-2558 145

ANL_89/32 6

ANL-90/7 286

ANL/EES-TM-377 292

ANL/ES-160 285

ANL/ESH/TS-90/103 297

ANSTO/E-675 331

ASTM Standards 1989, Section 12: Nuclear, Solar, and Geothermal Energy, 895 pp. 228, 229

Alomnaya Tekhnika za Rubczhom 12:23-25 126

Atomwirtschaft, Atomtechnik 34(2):94-97 59

BFR-R-88-1988 296

BNL-NUREG-51699 (Vol. 6) 227

Bulletin of the Ecological Socicty of Amcrica 68(3):372 318

CEA-CONF-9889 236

Commonwealth Scientific and Inclustrial Rescarch Organisation (CSIRO), Publisher, Canberra, Australia $\mathbf{3 3 6}$

Compilation of Contract Rescarch for the Materials Enginecring Branch, Division of Engincering - Annual Report for FY 1988 38,250

Compilation of Contract Research for the Matcrials Enginecring Branch, Division of Enginecring - Annual Report for FY 1987 213, 226, 239

CNEA-492 101
CONF-8507160 177

CONF-8609332 340

CONF-8609465 302

CONF-8609486 341

CONF-8611297 163, 168, 169, 190, 216, 220, 230, 255

CONF-871208 294, 295, 325, 328

CONF-880201 56, 60, 61, 68, 97, 112, 117, $138,151,176,182,200,209,253,262,307$, $315,348,361$

CONF-8803238 332,333

CONF-880404 76, 124

DONF-880633 127

CONF-8806409 330

CONF-8808110-Summ. 371

CONF-880815 (Vol. 1) 166, 215

CONF-880824 194

CONF-881009 161

CONF-881011 165

CONF-8810155 (Vol. 1) 214, 257

CONF-8810239 54, 306, 378, 379

CONF-8810305 236

CONF.881054 (Vol. 2) 368

CONF-881054 (Vol. 4) 188

CONF-881054 (Vol. 5) 304, 358

CONF-89(0207 276, 365, 369 
CONF-890470 394

CONF-8905318 242

CONF-890601 8

CONF-8907137 79

CONF-891006 102-111

CONF-8910274 9

CONF-891072 364

CONF-891077 57, 65, 75, 77, 93, 94, 114, 129, $139,164,172,183,201$

CONF-9X0210 235, 360, 363, 367, 390

CONF-9002121 372

CONF-9003134 12

CONF-9(0)4181 275, 305, 350

CONF-900608 376

CONF-900676 13

CONF-900679 349

CPDG-88-P208 145

Decommissioning of Nuclear Facilitics, Proceedings of an International Seminar, London, Unitod Kingdom, July 6-7, 1988 $16,58,67,78,81,86,125,148,150,162$, $170,197,224,260,264$

Decommissioning of Nuclear Installations, Procecdings of the 1989 International Symposium, Brussels, Belgium, October 24-27, 1989. Commission of the European Community, Brussels, Belgium 57, 65, 75, $77,93,94,114,129,139,164,172,183,201$
Decommissioning Offshore, Onshore and Nuclear Works, Whyte, I.L. (ed.), Procecodings of the First International Conference, Manchester, United Kingdom, March 22-24, 1988. Thomas Telford Limited, London, United Kingdom, 338 pp. 115,261

Dismantling of Nuclear Plants, Wastes and Associated Problems of Radiation Protection, Proceceding of an Association pour les Techniques et les Sciences de Radioprotection Mceting, Grenoble, France, October 5-7, 1988236

DOCKET 50)-238 245

DOE/EA-0368 320

DOE/EH-(0)79 (Vol. 2) 385

DOE/EH-8013171 386

DOE/EH-8013172 387

DOE/EIS-0132-F (Vol. I) 321

DOE/EIS-0132-F (Vol. II) 322

DOE/ER-0364 380

DOE/ER-0419 381

DOE/FE/60972-T1 366

DOE/HWP-40 357

DOE/HWP-72 371

DOE/HWP-99 372

DOE/ID-10276 218

DOE/ID/12584-45 343

DOE/ID/1258457 344

DOE/ID/12584-61 342 
DOE/OR/21548-127 32

DOE/IG-0284 382

DOE/NE-0025/4 323

DOE/NE-0025/4 (88) 324

DOE/NE/44139-54 244

DOE/NE/44139-58 202

DOE/NE/44139-59 87

DOE/OR/20722-193.1 (Draft) 269

DOE/OR/20722-203 (Vol. I) 289

DOE/OR/20722-203 (Vol. II) 290

DOE/OR/:0722-203 (Vol. III) 291

DOE/OR/20722-210.1 270

DOE/OR/20722-270 5

DOE/OR/21458-065 14

DOE/OR/21458-104 2

DOE/OR/21458-106 21

DOE/OR/21548-045 24

DOE/OR/21548-046 (Rev. 1) 25

DOE/OR/21548-063 26

DOE/OR/21548-066 27

DOE/OR/21548-078 28

DOE/OR/21548-082 29

DOE/OR/21548-094 (Rev. 2) 30

DOE/OR/21548-105 3

DOE/OR/21548-120 31
DOE/OR/23701-37.1 268

DOE/OR/31548-109 33

DOE/OSTI-8200-R53 246

DOE/RL-88-03 180

DOE/RL_88-40 391

DOE/RL_89-17 383

DOE/RL_89-29 384

DOE/RW-0006 (Rev. 5) 345

DOE/S-0070 388

DOE/S-0078P 370

DOE/S-90010604 (Draft) 389

DOE/SSDP-0053 44

DOE/SSDP-0076 45

DOE/SSDP-0080 46

DOE/SSDP-0081 47

DOE/SSDP_0082 37

DOE/SSDP-0083 48

Donen Giho 70:48-58 193

EGG-2505 (Vol. 1) 231

EGG-2505 (Vol. 2) 232

EGG-2575 22

ENEA-RT-PAS-89-2 181

Energeticheskoe Stroitel'stvo za Rubezhom 2:9-15 50 
Energeticheskoe Stroitel'stvo za Rubezhom 4:13-17 66

Energeticheskoe Stroitel'stvo za Rubezhom 4:8-13 238

Encrgeticheskoe Stroitel'stvo za Rubezhom 5:17-19 185

Encrgia Nucleare 6(3)-34-37 123

Environmental Science and Technology 23(3):290-294 329

EPA/ROD/R-08-89/025 42

EPAV60/8-87/049 355

EPRI-NP-6169 210

EPRI-NP-6454 98

EPS-3/MM/2 326

EUR-11482 83

EUR-1199595

Federal Register 54(129):28740 178

Federal Register 54(134):29732-29734 299

Federal Register 54(135):29957-29958 140

Federal Register 54(143):31266-31267 179

Federal Register 54(150):32731-32732 271

Federal Register 54(153):32837-32838 337

Federal Register 54(154):33101 339

Federal Register 54(171):37063 63

Federal Rugister 54(172):37174 133

Federal Register 54(174):37516-37517 258
Federal Register 54(180):33579 141

Federal Register 54(183):39066 234

Foderal Register 54(192):41190-41191 69

Federal Register 54(199):42607 85

Federal Register 54(210):46072 301

Fission Product Bchaviour and Source Term Rescarch, Proceedings of an Amcrican Nuclear Socicty Mecting, Snowbird, UT, July 15, 1985177

French Patent FR 2619953/A 205

Fusion Technology 15(2):1337-1342 173

GAO/RCED-89-119 121

GAO/T-RCED-90-16 374

Genshiryoku Anzen linkai Geppo 129:26 221

Geochemical Aspects of Radioactive Waste Disposal, Proceedings of a Symposium, Anaheim, CA, September 7-12, 1986302

Geoforum 20(4):381-396 195

Geotechnical Special Publication No. 21314

Geotechnical Stability in Surface Mining, Proceedings of the International Symposium, Calgary, Alberta, Canada, November 6-7, 1986300

Graphical Quality Assurance and Data Management on the UMTRA Project 316

HC-88 143

Health Physics 55(2):379-382 347

Health Physics 55(2):451-453 71 
Health Physics 56(4):431-440 335

Health Physics 58(3):321-328 308

House of Commons First Special Report from the Energy Committee (Session 1987- 88) 205144

House of Commons Second Report from the Energy Committee (Session 1986-87) 143

Human Factors and Power Plants, Proceedings of an International Conference, Monterey, CA, June 5-8, 1988127

HW-81300 158

Hydraulic Fill Structures, Proceedings of a Symposium, Fort Collins, CO, August 15-18, 1988314

IAEA-TECDOC-511 147, 154, 199, 204, 206

INFO-0219 341

INFO-0284 194

Information Bulletin 41, 43

INIS-SU-95 62, 186

INIS-XN-183 189

Isotopes in Nature, Procecdings of a Working Mecting, Leipzig, German Democratic Republic, September 22-26, 1986340

Jaderna Energie 34(5):176-179 100

JAERI-M-89-224 237

Japancse Patent JP 1-295199/A 157

Japancse Patent JP 1-3113(X)/A 136

Jet Cutting Technology, Proceedings of the Eighth International Symposium, Duram,
England, September 9-11, 1986 84, 142, $156,174,198,208$

John Wiley and Sons Inc., Publisher, New York, NY 34

Journal of Aerosol Science 19(7):1381-1384 233

Journal of Construction Engineering and Management 116(1):188 11

Journal of Nuclear Science and Technology 26(3):339-340 118

Journal of Nuclear Science and Technology 26(4):449-458 119

Journal of the RANDEC 1(1):1-61 212

KAERI/RR-798/88 192

Kerntechnik 55(2):98-103 252

Kurzberichte aus der Bauforschung 30(29):113-116 128

KY/H-104 (Rev. 1) 373

LA-UR-89-643 365

LA-11591-MS 284

Land Use Policy (8801):45-61 196

Laser Optoclektron 20(2):48-51 256

Lasers and Optronics 7:65-68 184

LIMET 88: Liquid Metal Engineering and Technology, Proceedings of an International Conference, Avignon, France, October 17-21, 1988, Vol. 1, 524 pp. 161

LMF-124 327 
Low-Level Radiation and Health, Proceedings of a Standing Conference, Stirling, United Kingdom, June 25-26, 1988330

Management of Low and Intermediate Level Wastes, Procecedings of an International Symposium, Stockholm, Sweden, May 1620, 1988, Vol. 1, 457 pp. 191

Mechanical Enginecring 3:60-69 131

Metallurgico Electricidad 2(599):91-96 267

Modern Power Systems (8811):32-33 211

Multilevel Rescarch - Molecules To Man, Proceedings of the 27th Hanford Health and the Environment Symposium, Richland, WA, October 18-20, 1989364

New Civil Engincer 874:22-24 134

Nippon Genshiryoku Gakkaishi 31(2):239-254 207

NISTTR-89-4086 80

Nuclear Engineering International 33(408):27-28 149

Nuclear Engincering International 34(416):17, 22-2399

Nuclear Engincering International 34(416):27-31, 33251

Nuclear Engineering International 34(420):23-24 74

Nuclear Enginecring International 34(420):24-28 15

Nuclear Engineering International 34(420):30-31 72

Nuclear Engineering International 34(420):34 146
Nuclear Engincering Intcrnational 34(420):35-36 135

Nuclear Enginecring International 34(420):39-40 70

Nuclear Enginecring 115(2-3):207-218 91

Nuclear Fission, Proccedings of the 1988 International Conference, Washington, DC, October 30-November 4, 1988 92, 122, 137, 219,346

Nuclear Materials Management, Proceedings of the 29th INMM Annual Mecting, Las Vegas, NV, Junc 26-29, 1988, 959 pp. 116

Nuclear Plant Journal 7(4):86-88 167

Nuclcar Power Plant Aging, Procecdings of an International Symposium, Bethesda, MD, August 30-September 1, 1988194

Nuclear Sciences and Applications, Proccedings of a Conference, Cairo, Egypt, March 6-10, 1988, 429 pp. 332, 333

Nuclear Technology 86(2):111-119243

Nuclear Technology 86(2):120-127 20

Nuclear Technology 86(2):128-135 73

Nuclear Technology 86(2):197-206 52

Nuclear Technology 86(2):97 171

Nuclear Technology 86(2):99-110 113

NUREG-(1975 (Vol. 6) 213, 226, 239

NUREG-19975 (Vol. 7) 38, 250

NUREG-1336 (Rev. 1) 247

NUREG-1337 (Rev. 1) 248

NUREG/CP-0x997 (Vol. 1) 214, 257 
NUREG/CP_0098 (Vol. 1) 166, 215

NUREG/CR-3444 227

NUREG/CR-4977 (Vol. 1) 231

NUREG/CR-4977 (Vol. 2) 232

NUREG/CR-5169 303

NUREG/CR-5381 203

NUREG/CR-5466 80

NUREG/CR-5489 327

NUREG/CR-5491 1

NUREG/CR-5512 155

ORAU-88/K-112 17

ORAU-89/A-42 287

ORAU-89/H-120 272

ORAU-89/H-91 273

ORAU-89/K-79 18

ORNL-6479 354

ORNL/M-1149 40

ORNL/M-665 371

ORNL/RASA-88/49 281

ORNL/RASA-88/50 282

ORNL/RASA-88/53 283

ORNL/RASA-88/67 278

ORNL/RASA-88/69 279

ORNL/RASA-88/79 280
ORNL/TM-10071/R2 90

ORNLTM-10416 266

ORNL/TM-10439 274

ORNL/TM-11182 277

PATRAM '89: Packaging and Transportation of Radioactive Materials, Proceedings of a Conference, Arlington, VA, June 11-16, 19898

PB-90-197625 42

Plant Life Extension for Nuclear Components, Proceedings of a Symposium, Honolulu, HI, July 24-27, 198979

PNL-SA-16826 364

PNL-SA-17282 363

PNL-SA-17283 360

PNL-SA-17285 235

PNL-6972 359

PNL-6976 153

PNL7154 303

PNL 7191 1

PNL_7195 377

PNL7212 155

PNL7229 393

POEF-2006 375

Pollution Enginecring 21(7):75-79 353

Power Europe 64:9-11 51 
Power Europe 66:9-10 240

Proceodings of a HAZWRAP Workshop, Salt Lake City, UT, August 9, 1988371

Proceedings of a Joint European Nuclear Society and American Nuclear Society Meeting, Washington, DC, October 30-November 4, 1988165

Proceedings of a Joint International Waste Management Conference, Kyoto, Japan, October 23-28, 1989, Vol. 1, 658 pp. 102-111

Proceedings of an International Radiation Protection Association Congress, Sydncy, Australia, April 10, 1988 76, 124

Proceedings of an U.S. Department of Energy, Office of Environmental Restoration and Waste Management Waste Reduction Workshop, Tampa, FI, February 6-7, 1990 372

Proceedings of the DOE/NRC Nuclear Air Cleaning Conference, Boston, MA, August 22-25, 1988166,215

Proceedings of the Ninth Annual Canadian Nuclear Society Conference, Winnipcg, Manitoha, Canada, Junc 13-15, 1988, 487 pp. 298

Proceedings of the U.S. Department of Energy Remedial Action Program Annual Mceting, Gaithersburg, MD, October 18-20, 1988, 555 pp. $54,306,378,379$

Proceedings of the U.S. Department of Energy Remedial Action Program Mecting, Albuquerque, NM, April 16-19, 1990 275, 305,350

Proceedings of the 15th Water Reactor Safety Information Mecting, Gaithersburg, MD, October 26-29, 198791
Proceedings of the 16th Water Reactor Safety Information Mecting, Gaithersburg, MD, Octobcr 24-27, 1988, 561 pp. 214, 257

Proccedings of the 1988 Annual DOE Model Conference, Oak Ridge, TN, October 3- 7, $1988188,304,368$

Procecedings of the 1988 Annual DOE Model Conference, Oak Ridge, TN, October 3- 7, 1988, Vol. 5358

Proceedings of the 1988 Annual Socicty of Mining Enginecrs Meeting, Phoenix, AZ, January 25-28, 1988313

Procecedings of the 1989 Annual DOE Model Conference, Oak Ridge, TN, October 3- 6, 1989, 54 pp. 7, 23, 223, 259, 293, 356, 362

Proceedings of the 1990 Annual Air and Waste Management Association Mecting and Exhibition, Pittsburgh, PA, Junc 24-29, 199013

Proccedings of the 1990 Annual American Nuclear Society Mecting, Nashville, TN, June 10-14, 1990 376

Proceedings of the 1990 Annual Health Physics Socicty Mecting, Anahcim, CA, June 24-28, 1990349

Proceedings of the 1990 Annual Health Physics Society Mecting, Richland, WA, March 22, 199012

Proccedings of the 29th Annual INMM Mecting, Las Vegas, NV, Junc 26-29, 1988, Nuclear Materials Management, 959 pp. 351

Radiation Protcction - A Look to the Future, Procecedings of the 25th Hanford Life Sciences Symposium, Richland, WA, October 21-23, 1986 71, 347 
Radiation Protection Dosimetry
24(1-4):101-108 294

Radiation Protection Dosimetry 24(1-4):149-153 325

Radiation Protection Dosimetry 24(1-4):155-158 328

Radiation Protection Dosimetry 24(1-4):531-535 295

Radiation Protection Principles for Management of Solid Radioactive Waste, Proccedings of a Closed Mecting of the Strahkenschutzkommission, Gundremmingen, Federal Republic of Germany, November 6-7, 1986, Vol. 11, 223 pp. 163, 168, 169, $190,216,220,230,255$

Radioactive Waste Focus SP.I-89.44(11):1-11 82

Radioactive Waste Management, Proceedings of a Canadian Nuclear Socicty International Conference, Winnipeg, Ontario, Canada, September 7-11, 1986341

Radiological Surveillance of Remedial Action Activities at the Processing Site - Durango, Colorado, May 16-18, 1989309

Rayonnements Ionisants 18(1):35-45 225

Rayonnements Ionisants 4:8-15 10

Recht der Elektrizitactswirtschaft 50(12):306-311 241

\section{REG/G-3.65 249}

Regulatory Practices and Safety Standards for Nuclear Power Plants, Procecdings of an International Symposium, Munich, Federal Republic of Germany, November 7-10, 1988, 583 pp. 159

Robot 67:39-45 120
Robot 67:46-56 222

Robotics World 7(2):42-43 254

Safety and Reliability of Plant Technology, Proceedings of the 15th MPA Seminar, Stuttgart, Federal Republic of Germany, October 5-6, 1989, Vol. 2, 784 pp. 9

SAND-88-1761C 35

SAND-88-3347C 36

SAND-89-1302 203

Severe Accidents in Nuclear Power Plants, Proceedings of an International Symposium, Sorrento, Italy, March 21-25, 1988, Vol. 2, 722 pp. 96

Soviet Atomic Encrgy (8810):299-306 160

SSI-88-08 64

Technology of Fusion Energy, Proccedings of the Eighth Topical Meeting, Salt Lake City, UT, October 9-13, 1988173

Telegraph Weckender Magazine (United Kingdom) (890218):24-28, 30265

The AVR Reactor, Proceedings of a VDI Technical Meeting, Aachen, Federal Republic of Germany, May 17-19, 1989, Vol. 729, 322 pp. 242

The Carbide and Tool Journal 5:16-23 132

The Natural Radiation Environment, Proceedings of the Fourth International Symposium, Lisbon, Portugal, December 7-11, 1987 294, 295, 325, 328

Training of Nuclear Facility Personnel, Procecdings of a Symposium, Gatlinburg, TN, April 23, 1989394 
Transactions of the American Nuclear Socicty 57:167-169 346

Transactions of the Amcrican Nuclear Socicty 57:455-456 165

Transactions of the American Nuclear Society $57: 45892$

Transactions of the American Nuclear Socicty 57:467-469 219

Transactions of the Amcrican Nuclear Socicty 57:480-481 122

Transactions of the American Nuclear Soxicty 57:481-482 137

Transactions of the American Nuclear Socicty 59:348-50 130

Transactions of the American Nuclear Society 59:44-45 187

Transactions of the Indian Institute of Metallurgy 40(4):343-345 152

U.S. Congress, House of Representatives, Committee on Ways and Means, Washington, DC, One Hundredth Congress, Second Session, August 10, 1988, Serial 100-79:90-968. U.S. Government Printing Office, Washington, DC, 1988338

UCRL-100788 49

UCRL-101777 8

UCRL-99652 19

UMTRA-ESHA-2 312

Umwelt- und Planungsrecht 10(3):119-120 89

UNC/GJ-50(TMC) 344
UNC/GJ-51(TMC) 342

Uranium (Netherlands) 4(4):385-394 334

Waste Management '88: Waste Processing, Transportation, Storage and Disposal Technical Programs and Public Education, Post, R.G. (ed.), Procecedings of a Conference, Tucson, AZ, February 26-March 3, 1988, Vol. 1, 1049 pp. 56, 253, 315,348

Waste Management '88: Waste Processing, Transportation, Storage and Disposal. Technical Programs and Public Education, Post, R.G. (cd.), Procecedings of a Conference, Tucson, AZ, February 26-March 3, 1988, Vol. 2, 1052 pp. 60, 61, $68,97,112,117,138,151,176,182,200$, $209,262,307,361$

Waste Management '89, Procecedings of the 15th International Waste Conference, Tucson, AZ, February 26-March 2, 1989 $276,365,369$

Waste Management ' 90 : Working Towards a Cleaner Environment - Waste Processing, Transportation, Storage and Disposal, Technical Programs and Public Education, Procecedings of a Conference, Tucson, AZ, February 25-March 1, 1990 235, 360), 36.3, 367,390

Water System of Nuclear Reactor Systems 5 217

Welding Design and Fabrication 62(5):25-28 263

Welding in the World 25(5/6):88-99 53

Welding International 3(7):562-563 88

Welding Journal (8907):22-27 175 
WHC-SA-(1246 4

WHC-SA-0877 12
WHC-SP-0428 392

YJT-89-02 55 
$267 / 268$

GEOGRAPHIC LOCATION INDEX 


\section{DOMESTIC SITES}

Arizona, Monument Valley, Monument Valley Site 320

California, Los Angeles, University of California, Argonaut Reactor Facility 179

California, Los Angeles, University of California, TIGRA Research Reactor Facility 141, 258

Colorado 335

Colorado, Durango, Durango Site 309,311

Colorado, Durango, Durango Site, UMTRA Disposal Cell 317

Colorado, Mesa County 344

Colorado, Rifle, New Rifle Site 321,322

Colorado, Rifle, Old Rifle Site 321,322

Idaho, Idaho Falls, Idaho National Enginecring Laboratory, Heat Transfer Reactor Experiment 2 (HTRE-2) 22

Idaho, Idaho Falls, Idaho National Engincering Laboratory, Heat Transfer Reactor Experiment 3 (HTRE-3) 22

Illinois, Argonne, Argonne National Laboratory, Experimental Boiling Water Reactor 6,7

Illinois, Chicago, University of Chicago, Jones Chemical Laboratory 287

Illinois, Cook County, Palos Park Forest Preserve Site 286

Kentucky, Paducah, Paducah Gascous Diffusion Plant 373
Maryland, Baltimore, W.R. Grace Company Curtis Bay Sito 274

Michigan, East Lansing, Michigan State University, TIGRA Nuclear Reactor 140, 178

Missouri, St. Charles County 43

Missouri, St. Charles County, Weldon Spring Site $13,23,24,28,29,31-33,40$

Missouri, St. Charles County, Weldon Spring Site, Quarry 2, 3, 14, 25-27, 30

Missouri, St. Charles County, Weldon Spring Site, Weldon Spring Chemical Plant 21, 41

Missouri, St. Louis County, Coldwater Creek and Associated Properties 289-291

Missouri, St. Louis County, Haul Roads and Assuciated Properties 289-291

Missouri, St. Louis County, Latty Avenue Vicinity Properties 289-291

Missouri, St. Louis County, Norfolk and Western Railroad Properties 289-291

Missouri, St. Louis County, St. Louis Airport Site Vicinity Properties 289- 291

Nevada, Nevada Test Site 71

New Jersey, Glen Ridge, Barrows Field Park 297

New Jersey, Lodi 278-283

New Jersey, Maywood, Maywood Interim Storage Site 269

New Mexico, Los Alamos, Los Alamos National Laboratory 284 
New York, Albany, Albany Vicinity Propertics 271

New York, Colonie, Colonic Interim Storage Site 270, 275

New York, Colonic, Colonie Interim Storage Site Vicinity Propertics 271-273

New York, Lewiston, Niagara Falls Storage Site 5,17

New York, Tonawanda, Ashland Oil Company No. 1 Site 275, 276

New York, Tonawanda, Ashland Oil Company No. 2 Site 275, 276, 288

New York, Tonawanda, Haist Property 276

New York, Tonawanda, Linde Air Products Site 275,276

New York, Tonawanda, Seaway Industrial Park Site 275, 276

New York, West Valley, Nuclear Fuel Services Reprocessing Plant 202

New York, West Valley, West Valley Demonstration Project Site 60, 61, 68, 87, $97,112,138,151,176,200,209,244,262$, 343

Ohio, Luckey, Former Diamond Magnesium Company Site 277

Ohio, Piketon, Portsmouth Gascous Diffusion Plant 375

Oregon, Lake County, Frecmont National Forest, White King/Luck Lass Mine Site 337

Pennsylvania, Middletown, Three Mile Island Nuclear Station, Unit 2 92, 96, 98, 122, 130, 137, 165, 175, 177, 211, 218, 219
Pennsylvania, Shippingport, Shippingport Atomic Power Station 4, 9, 11, 16, 18, 19 , $35,37,44.49$

Tennessec, Erwin, Nuclear Fucl Services, Inc. Plutonium Fabrication Facility 259

Tennessec, Oak Ridge, Oak Ridge Reservation 350

Tennessec, Oak Ridge, Oak Ridge Reservation, Elza Gate Sitc 268

Utah, Monticello, Monitcello Vicinity Propertics 42

Washington, Richland, Hanford Rescrvation $383,384,389,392$

Washington, Richland, Hanford Reservation, 200 Area, Strontium Semiworks Facility 20

Washington, Richland, Hanford Reservation, 324 Building 153

Washington, Richland, Hanford Site 15

\section{FOREIGN SITES}

Australia, Northern Territory, Jabiru, Ranger Uranium Mining Complex 329, 331

Belgium, Brussels $57,65,75,77,93,94,114$, $129,139,164,172,183,201$

Canada, Ontario, Bancroft, Madawaska Uranium Mine 341

Canada, Ontario, Port Hope 298

Canada, Quebec, Gentilly, Gentilly 1 Station 106

Federal Republic of Germany 89 
Federal Republic of Germany, Bayernwerk, RWE-Bayernwerk Reactor, Unit A 168

Federal Republic of Germany, Berlin, BER II Reactor 59

Federal Republic of Germany, Brunsbucttel Power Station 168

Federal Republic of Germany, Grosswelzheim, Heissdampfreaktor (HDR) Nuclear Power Station 231, 232

Federal Republic of Germany, Gundremmingen, Gundremmingen Nuclear Power Station 163

Federal Republic of Germany, Gundremmingen, Gundremmingen Nuclear Power Station, Unit A Reactor 230, 252

Federal Republic of Germany, Karlsruhe Nuclear Research Center, MZFR Reactor 169

Federal Republic of Germany, Karlsruhe, FR-2 Reactor 169

Federal Republic of Germany, Karlsruhe, Karlsruhe Nuclear Research Center 169

Federal Republic of Germany, Lanshut, Niederaichbach Nuclear Power Station 105, $170,220,241,252$

Federal Republic of Germany, Lingen, Lingen Nuclear Power Station 168, 252

Federal Republic of Germany, Worms, Biblis Power Station, Unit A 168

Finland, Loviisa, Loviisa Nuclcar Power Station 55

France, Gard, Marcoule, Marcoule G-2 Reactor 236
France, Saclay, EL-3 Reactor 225

France, STMI Pilot Facility 78

Italy, Latina, Latina MAGNOX Nuclear Power Plant 127

Italy, Rome, RB-2 Reactor Site 73

Italy, Sessa Aurunca, Garigliano Reactor 123

Japan 191

Japan, Tokai, Japan Atomic Energy Research Institute, Japan Power Demonstration Reactor 103, 108, 149, 193, 221, 222, 237, 238

Portugal 294

Spain 325,328

United Kingdom, Berkeley Atomic Power Station 74

United Kingdom, Cumbria, Seascale, Sellafield, British Nuclear Fuels Limited Site 81, 182, 223

United Kingdom, Cumbria, Seascale, Sellafield, United Kingdom Atomic Energy Authority, Windscale Nuclear Laboratories, Windscale Advanced Gas-Cooled Reactor 67, 215, 243,260

United Kingdom, Hinkley Point Power Station, Hinkley Point A-1 Reactor 143, 144

United Kingdom, Suffolk, Sizewell Nuclear Power Plant 196

USSR, Chernobyl Nuclear Power Station, Unit 4160 
$273 / 274$

SUBJECT CATEGORY INDEX 


\section{SURPLUS FACILITIES MANAGEMENT PROGRAM}

Design, Planning, and Regulations 3, 6, 15, $21,41,43$

Environmental Studies and Site Surveys 1, 2, $5,12,17,18,23-29,31-33,35,36,40$

Health, Safety, and Biomedical Studies 13, 14, 34

Decontamination Studies 16, 45
Dismartlement and Demolition 8, 10, 11, 19, $20, \therefore 49$

Site Stabilization and Reclamation 42

Waste Disposal 4, 9, 30, 38

Remedial Action Experience 7, 22, 37, 46-48

General Studies 39

\section{NUCLEAR FACILITY DECOMMISSIONING}

Design, Planning, and Regulations 63, 64, 67, $69,75,87,89,90,101,116,121,126,138$, $143,144,150,159,164,167,169,170,195$, 196, 201, 203, 206, 220, 228, 239-241, 245, $247-249,257,264$

Environmental Studies and Site Surveys 55, $98,130,139,158,168,181,213,214,237$

Health, Safety, and Biomedical Studies 77, 92, $122,124,127,137,155,187,188,194,216$, 229

Decontamination Studies $68,91,94,99,100$, $104,105,117-119,135,136,145,152-154$, $157,161,163,165,173,177,183,192,199$, $204,210,2 i 7,219,226,227,235$

Dismantlement and Demolition 53, 57, 59, 62, $65,73,74,78,80,84,88,93,95,103,114$, $115,120,128,129,131,132,134,140-142$, $149,156,166,172,174,175,178,179$,
184-186, 190, 193, 198, 202, 205, 207, 208, 211, $215,221,222,225,230,233,236,238,242$, $243,254,256,258,261,263,267$

Site Stabilization and Reclamation 71,86 , 160,266

Waste Disposal $52,60,66,70,76,97,102$, $106,109,110,112,151,176,191,197,200$, $209,234,253,262$

Remedial Action Experience 61, 218, 244, 255

Gencral Studies $50,51,54,56,58,72,79$, $81-83,85,96,107,108,111,113,123,125$, $133,146-148,162,171,180,182,189,212$, $223,224,231,232,246,250-252,259,260$, 265 


\section{FORMERLY UTILIZED SITES REMEDIAL ACTION PROGRAM}

Design, Planning, and Regulations 270, 276

Environmental Studies and Site Survcys 271-275, 277-283, 286-292

Health, Safety, and Biomedical Studies 285

Decontamination Studies 269
Dismantlement and Demolition 268

Waste Disposal 293

General Studies 284

\section{FACILITIES CONTAMINATED WITH NATURAL RADIOACTIVITY}

Design, Planning, and Regulations 295

Environmental Studies and Site Surveys 294, 296
Waste Disposal 297

Remedial Action Experience 298

\section{URANIUM MILL TAILINGS REMEDIAL ACTION PROGRAM}

Design, Planning, and Regulations 304, 316

Environmental Studies and Site Surveys 302, $307-310,314,315,31 \%-322$

Health, Safety, and Biomedical Studies 305, 311,312
Site Stabilization and Reclamation 300, 313

Waste Disposal 303, 306

General Studies 299, 301, 323, 324

\section{URANIUM MILL TAILINGS MANAGEMENT}

Environmental Studies and Site Surveys 328, $329,331,334,340$

Health, Safety, and Biomedical Studies 325, 327,330

Decontamination Studics $326,332,333$
Site Stabilization and Reclamation $335-339$

General Studies 341 
TECHNICAL MEASUREMENTS CENTER

Environmental Studies and Site Surveys 343, Gencral Studies 342 344

\section{REMEDIAL ACTION PROGRAM}

Environmental Studies and Site Surveys 348, 351

Health, Safety, and Biomedical Studies 346, 347, 352
Site Stabilization and Reclamation 353

Waste Disposal 345,349

General Studies 350

\section{ENVIRONMENTAL RESTORATION PROGRAM}

Design, Planning, and Regulations 354,355 , $357-365,369-372,374,377,378,381-384$, $388-391,393,394$

Environmental Studies and Site Surveys 373, 376,380
Health, Safety, and Biomedical Studies 366 , 385-387

Sitc Stabilization and Reclamation 356

General Studies $367,368,379$ 
$279 / 280$

KEYWORDS INDEX 
ABRASION 104

ABRASIVES 84, 129, 131, 132, 156, 184, 254

ACCIDENTS 8, 30, 69, 86, 96, 122, 130, 133, $160,165,175,177,189,196,203,218,219$, $251,257,266,346$

ACCOUNTABILITY 259

ACCOUNTING 240

ACTINIUM-228 275

ACTIVITY LEVELS 76, 124, 214

ADDITIVES 165

ADMINISTRATIVE PROCEDURES 85, $241,365,371,372,392$

ADSORPTION 303,313

AERIAL RELEASES 182

AEROSOLS $57,65,94,95,146,166,183$, $205,215,233,335$

AGING 38, 79, 91, 194, 257

AGR TYPE REACTORS 51, 182, 197, 215, 240

AGREEMENTS 377,383

AIR COOLED REACTORS 134

AIR FILTERS 122, 166, 215

AIR POLLUTION 34, 275, 335

AIR POLLUTION CONTROL 32

ALARA $12,45,92,137,143,144,178,179$, $210,221,264,285,347$

ALKALI METAL COMPOUNDS 165
ALKALI METAL ISOTOPES 117, 165, 218

ALKALINE EARTH ISOTOPES 25, 55, $165,268,269,278-282,333,334,340,348$

ALKALINE EARTH METALS 302, 331, 332

ALLUVIAL DEPOSITS 321

ALPHA DETECTION 139, 325, 344

ALPHA DOSIMETRY 328

ALPHA RADIATION 139, 308, 342

ALPHA SPECTROMETERS 325

ALUMINUM 173

AMERICIUM-241 139

ANIMALS 322

ANODES 136

AQUEOUS SOLUTIONS 165

AQUIFERS 366

ARC WELDING 88, 165

ARCHAEOLOGICAL SITES 269

ARGONAUT REACTOR 179

ASBESTOS 7, 22, 37, 40, 44, 180

AUDITS 305, 309-312, 382

AUSTENITTC STEELS 186

AUTOMATION 62

AUXILIARY SYSTEMS 213

AUXILIARY WATER SYSTEMS 213 
AVR REACTOR 242

BACKGROUND RADIATION 274, 344

BACTERIA 334

BARGES 39, 49

BARIUM 28

BASELINE ECOLOGY 292

BENCHMARKS 4

BERKELEY REACTOR 265

BERYLLIUM 277

BETA DETECTION 139,343

BIBLIS-A REACTOR 89

BIOASSAY 327

BIOLOGICAL SHIELDS 120, 214, 237

BITUMENS 109, 111, 332, 333

BOILERS 192, 199

BOREHOLES $25,142,286$

BORROW SITES 320,322

BOUNDARY CONDITIONS 288

BREEDER REACTORS 90

BUDGETS $324,362,375,383$

BUILDING MATERIALS 66, 95, 145, 177 , $214,226,268,296,330$

BUILDINGS $12,18,31,46,50,92,115,137$, $155,165,177,218,219,239,271,274$, $279-283,295,296$
BULK-MOX EVALUATION 259

BURIAL 5, 39, 121, 286, 298

BWR TYPE REACTORS $6,7,79,90,126$, $154,163,168,181,187,210,213,214,226$, $230,231,238,239,255,257$

CADMIUM 130

CALCULATION METHODS 155, 229, 262, $297,328,351$

CALIBRATION 284, 305, 309-312, 342, 343

CANDU TYPE REACTORS 106,116

CARBON DIOXIDE 128,256

CARBONDIOXIDECOOLEDREACTORS $169,220,239,265$

CARBON STEELS 9, 35, 62, 118, 119, 226

CARBON-14 109, 139, 237, 268, 333

CARCINOGENESIS 347

CASKS 226

CASTING 38

CAVITIES 25

CEMENTS 68, 145, 226

COMPREHENSIVE ENVIRONMENTAL RESPONSE, COMPENSATIONS, AND LIABILITY ACT 23, 32, 356, 362, 364

CERTIFICATION 121,324

CESIUM 118, 119

CESIUM ISOTOPES $117,165,218$

CESIUM-134 237 
CESIUM-137 97, 139, 165, 176, 218

CHALCOGENIDES $\quad 331-333$

CHARGED PARTICLES 193, 226

CHARPY TEST 9, 35, 36

CHEMICAL ANALYSIS 23, 25, 214

CHEMICAL COMPOSITION 56, 112, 200, $209,262,345$

CHEMICAL DECLADDING 136

CHEMICAL DURABILITY 112, 200, 209, 262

CHEMICAL, PLANTS 21, 25, 31, 41

CHEMICAL REACTIONS 38, 91, 161, 192, $193,213,226,313,333$

CHEMISTRY 163, 199, 213, 218, 235

CHERNOBYL-4 REACTOR 86, 148, 160, 266

CHLORINE 109

CHROMTUM ALLOYS 100, 186, 226

CHROMIUM-NICKEL STEELS 186, 226

CLADDING 182

CLASSIFICATION 98, 214, 292, 349

CLAYS 5, 318

CLEANING $6,12,43,71,75,76,93,95,103$, $117,135,136,147,153,154,157,163,165$, $166,172,177,181,192,193,199,203,208$, $210,214,218,225,226,230,235,236,239$, $244,257,271,285,299,353,356,381$

COAL $33,174,340$
COATINGS 165

COBALT 100

COBALT-60 139, 237

COLLOIDS 95, 166, 205, 215, 335

COMBUSTION 191

COMMERCIAL BUILDINGS 274, 281, 282

COMMINUTION PROCESS 174

COMPACTION 182

COMPARATIVE EVALUATIONS 38, 90, $115,129,239,377$

COMPILED DATA $101,226,357$

COMPLIANCE $12,23,32,40,54,110,245$, $252,269,270,275,276,306,354,357$, $363-365,369-371,375,377,379,382,384$, $385,388,389,393$

COMPRESSION STRENGTH 208

COMPUTER CALCULATIONS 351

COMPUTER CODES 55, 206, 213, 214, 285, $308,351,352,359$

COMPUTERIZED SIMULATION 8, 19, 127, 206, 218

CONCENTRATION RATIO 155, 289-291, 294

CONCENTRATORS 30

CONCRETES $7,80,84,94,95,103,114,115$, $120,128,131,132,156,170,172,177,183$, $198,202,208,212,214,222,254,261,268$

CONSTRUCTION $42,43,53,90,101,142$, $196,202,317$ 
CONTAINMENT $6,50,75,116,123,165$, $218,239,245,259$

CONTAINMENT BUILDINGS 11, 50, 165 , 218, 239

CONTROL EQUIPMENT $38,79,130,199$

CONTROL MONITORS 344

COOLANTS 226

COOLING SYSTEMS 38, 154, 183, 199, 204, $213,214,225,239$

COOPERATION 147, 216, 218, 323, 378

COPPER 331

CORROSION 38, 91, 100, 143, 144, 152, 161, $192,208,213,226,227$

CORROSION PRODUCTS 157, 165, 210, 226, 227

CORROSION PROTECTION 100, 152

CORROSION RESISTANT ALLOYS 186 , 226

COST $22,37,39,45,46,77,84,90,126,139$, $142-144,150,162,184,195-197,201,206$, $213,235,238,240,243,266,346,355,356$, $368,375,381,386-389$

COST BENEFIT ANALYSIS 21, 268

COST ESTIMATION $6,30,101,150,185$, $240,355,370,371,373,385,392$

COVERINGS 5,322

CRACKING 38, 226

CRANES 11

CRUD 212
CRYSTAL STRUCTURE 38,151

CURRENTS 62,186

CUTTING 7, 53, 57, 62, 65, 84, 88, 114, 120, $128,129,131,132,134,156,166,170,172$, $175,184,186,202,208,211,212,222,223$, $254,256,263,267$

CUTTING TOOLS $62,88,103,128,175,186$, $202,254,263$

DAMAGE $96,114,156,198,208$

DAMS 329, 331

DATA ACQUISITION $165,189,218,239$, 288

DATA ANALYSIS $201,218,239,262,302$

DATA BASE MANAGEMEN'T 90, 110, 123, $201,213,257,316,350,359$

DATA COMPILATION 239

DATA MANAGEMENT 167

DATA PROCESSING 90

DAUGHTER PRODUCTS 30, 268, 295

DEBRIS 42, 130

DECISION MAKING $87,90,218,264,269$, $270,322,354,365$

DECISION TREE ANALYSIS 22, 264

DECLADDING 190

DECOMPOSITION 38, 226

DEFUELING 96, 116, 125

DEGRADATION PROCESSES 91 


\section{DEMINERALIZERS 226}

DEMOLTTION $10,20,44,49,73,95,101$, $115,134,163,169,185,190,213,214,216$, $220,225,230,236,239,255,261,265$

DEMONSTRATION PROGRAMS 68, 138, 260,315

DENSITY 5

DEPOSITION 327

DEPOSITS 204

DEPTH 103

DESIGN $15,43,129,183,218,266,320,322$

DESIGN CRITERIA 322

DESTRUCTIVE TESTING 35,36

DETERGENTS 165

DEWATERING EQUIPMENT 30

DIMENSIONS 62

DISASTERS 86, 336

\section{DISINTEGRATION 174}

DISMANTLEMENT 7, 9-11, 18, 22, 44, 46, $49,57,72,73,75,77,93,101,102,109,111$, $114,125,128,140,141,146,164,170,172$, $175,178-180,185,196,201,211,214$, $221-225,237,241-243,258,265$

DISPERSIONS $95,165,166,205,215,306$, 335,379

DISSOLUTION $118,119,145,227,313$, $331-333$

DOCUMENTATION $12,121,218,228,272$, $273,287,324$
DOSE COMMITMENTS 187,346

DOSE EQUIVALENTS 124, 155, 179, 327

DOSE LIMITS 110, 229, 241, 285, 347

DOSE RATES $29,34,77,187$

DOSIMETRY 103, 130, 187, 229, 298, 325, $327,328,347$

DRAINAGE 156,317

DRILJING 284, 288

DRINKING WATER $2,3,14,26-28,155$, 286, 292

DUCTS 287

DUSTS $42,94,95,114,327$

EAR'THQUAKES 231,232

EBWR REACTOR 6,7

ECOLOGICAL CONCENTRATIC $、 13,25$, $30,158,268,269,274,278-283$

ECONOMIC ANALYSIS 90, 150, 203, 355

ECONOMICS 77, 90, 164, 183, 203, 208, 239, 353

EDUCATIONAL FACILITIES 295

EFFICIENCY 154, 174, 177, 253

EFFLUENTS 182,328

EL-3 REACTOR 225

ELECTRIC ARCS 62, 186

ELECTRIC CONDUCTIVITY 62

ELECTRIC CURRENTS 62,186 
ELECTRIC DISCHARGES 62,186

ELECTRIC UTILITIES 143, 144, 150, 187

ELECTRICAL PROPERTIES 62

ELECTRICITY 6

ELECTROCHEMISTRY 163,199

ELECTRODES 88, 136, 233

ELECTROMAGNETIC RADIATION 226, $274,278-283,348$

ELECTROMAGNETIC SURVEYS 284

ELECTRON MICROSCOPY 38,213

ELECTRON TUBES 62,186

ELECTROPOLISHING $82,99,104,152$

ELECTROSTATIC PRECIPITATORS 215

EMANOMETERS 296

EMBANKMENTS 329

EMBRITTLEMENT 9, 35, 36

EMERGENCY PLANS 30, 86

EMISSION 40, 270

ENCAPSULATION 182

ENERGY SOURCES 214,340

ENERGY SYSTEMS 38, 154, 199, 204, 213, $214,225,239$

ENGINEERED SAFETY SYSTEMS 203

ENRICHED URANIUM REACTORS 4, 6, $8,12,19,35,36,38,49,51,55,79,154,163$,
$165,168,169,177,189,199,213-215,218$, $220,225,230,238,239,255$

ENTOMBMENT 86

ENVIRONMENTAL ASSESSMENTS 320

ENVIRONMENTAL EFFECTS 14,377

ENVIRONMENTAL EXPOSURE 269, 270

ENVIRONMENTAL EXPOSURE PATHWAY 124, 229, 241, 346, 352

EN VIR O N M EN TA L I M PACT STATEMENTS 87, 133, 140, 178, 234, 269, 320-322, 337

ENVIRONMENTAL IMPACTS 14, 23, 140, $167,214,234,264,292,330,363,373,385$, 392,393

ENVIRONMENTAL POLICY 354, 360-362, $370,374,375,388,391$

ENVIRONMENTAL PROTECTION 264, $286,305,309,311,312,350,382,384,390$

ENVIRONMENTAL QUALITY 264, 354

ENVIRONMENTAL TRANSPORT 187, $302,331,335,348,366$

EPIDEMIOLOGY 367

EPITHERMAL REACTORS 90

EQUIPMENT $31,38,56,60,61,79,99,104$, $105,108,117,120,134,166,193,199,205$, $207,213,215,222,229,243,266,274$

EROSION 336, 339

EROSION CONTROL 5, 339

EUROPIUM-152 237 
EUROPIUM-154 237

EVALUATION $1,4,172,177,213,226,239$, $244,296,319,354,360,375$

EVAPORATION 182

EVAFORATORS 212

EXCAVATION 29, 30, 42, 71, 84, 298, 381

EXPERIMENTAL DATA 25, 331

EXPERIMENTAL REACTORS 6, 154, 189, 238

EXPOSURE RATES 289-291

EXTENDED-LIFE SERVICE 91

FABRICATION 38,259

FAILURE MODE ANALYSIS 218

FAILURES 50

FARMS 266

FAST REACTORS 90

FBR TYPE REACTORS 90, 100

FEASIBILITY STUDIES 23

FILTERS $57,65,94,95,134,166,205,215$, 223,342

FINANCING 214,248

FINITE ELEMENT METHOD 8

FIRE HAZARDS 386, 387

FISHES 322

FISSION PRODUCT RELEASE 96, 177, 2.57
FISSION PRODUCIS 130, 177, 218, 349

FLOODPLAINS 322

FLOODS 336

FLOORS 165

FLOW RATE 129

FLOW REGULATORS 199

FLOWSHEETS $12,238,365$

FLUID MECHANICS 218

FLUIDS 205, 295, 296

FLY ASH 33

FOOD 308

FORECASTING 158, 185, 213, 352, 385

FOSSIL FUELS 40, 180, 340

FOUNDATIONS 115

FR-2 REACTOR 169

FUEL ASSEMBLIES 213, 214, 338

FUEL CYCLE 107, 164, 213, 226, 239

FUEL ELEMENTS 90, 213, 218

FUEL FABRICATION PLANTS 81, 107, $191,203,223,259,338$

FUEL MANAGEMENT 239

FUEL POOLS 213, 221, 237

FUEL REPROCESSING PLANTS 51, 58, $81,97,107,111,176,182,202$

FUELS 58, 178, 214, 240, 340, 345 
FUNCTIONAL MODELS 39, 253

FUNDING $133,150,323$

FURNACES 235

GAMMA DETECTION $17,139,146,272$, $273,277,325,343$

GAMMA LOGGING 281, 282, 289-291, 343

GAMMA RADIATION $130,139,226,227$, $274,278-283,285,348$

GAMMA SPECTRA 130, 213

GAMMA SPECTROMETRY 17, 272, 273

GAMMA SPECTROSCOPY 25, 294

GARIGLIANO REACTOR 123

GAS COOLED REACTORS 51, 90, 109, $134,164,169,215,220,239,257,265$

GASEOUS DIFFUSION 373

GCR TYPE REACTORS 51, 215, 265

GELS 82

GEOCHEMICAL PROCESSES 303

GEOCHEMICAL, SURVEXS 189, 3()2, 324

GEOCHEMISTRY 303,313

GEOLOCIIC DEPOSITS 2, 3, 14, 26, 27

GEOLOGY $269,300,322,336$

GEOMORPHOLOGY 336

GEOPHYSICAL SURVEYS 284

GEOPHYSICS 353
GEOTECHNICAL PROPERTIES 314

GEOTECHNICAL STABILITY 300

GLASS $112,200,262$

GLOVEBOXES 56, 93, 191, 193, 259

GOALS 374,388

GOVERNMENT POLICIES 388

GRAPHITE 109

GRAPHITE MODERATED REACTORS $51,90,134,215,257,265$

GREEN FIELD CONDITIONS 170

GRINDING 157

GROUND DISPOSAL $6,49,335,380$

GROUND WATER $2,3,5,13,14,21,23$, 24, 26-30, 41, 43, 54, 121, 155, 209, 281, 282, $286,292,302,304,317,319,321,322,34()$, $353,358,366,380,381,389$

\section{GROUTING 142}

GUIDELINES 23, 116, 121, 146, 159, 229, $305,307,309-312,341,347,356,374$

GUNDREMMINGEN REACTOR 252

HALOGENATED AROMATIC HYDROCARBONS 40

HANFORD PRODUCTION REACTORS $15,158,383,384,389$

HAZARDOUS MATERIALS $2,3,13,14$, $24,26,27,40,42,203,270,275,349,354$, $357,360,363,365,366,368,372,379,380$, $391,393,394$

HBWR REACTOR 189 
HDR REACTOR 231, 232

HEALTH EFFECTS $14,69,155$

HEALTH HAZARDS $13,14,34,40,56,122$, $137,219,268,274,278-283,286,289,296$, $327,330,347,373$

HEARINGS $179,299,301$

HEAT AFFECTED ZONE 53, 62

HEAT EXCHANGERS 225

HEAT RESISTANT MATERIALS 186, 219, 226

HEAT RESISTING ALLOYS 186, 226

HEAT TRANSFER REACTOR 22

HEAT TREATMENTS $38,151,173$

HEAVY WATER COOLED REACTORS $169,189,225$

HEAVY WATER MODERATED REACTORS 169, 189, 220, 225, 239

HFIR REACTOR 35

HIGH ALLOY STEELS 38, 186, 214

HIGH-LEVEL RADIOACTIVE WASTES

$56,60,61,68,111,151,182,345,348,349$, 372

HIGH-PRESSURE WATER 142

HOMOGENEOUS REACTORS 2.39

HOT CELLS 153, 21.3, 235, 236

HOUSES 295

HTGR TYPE REACTORS 9), 257
HUMAN FACTORS 257

HUMAN POPULATIONS 34, 40, 269, 270, 360

HUMIDITY 123

HWGCR TYPE REACTORS 169, 220, 239

HYDRAULICS 218, 231

HYDRIDE MODERATED REACTORS 239

HYDROCHLORIC ACID 173, 333

HYYDROGEN COMPOUNDS 54, 163, 225, $281,282,292,302,304,331,333,340$

HYDROGEN ISOTOPES 225

HYDROLOGY $313,322,358$

IMPACT TESTS $4,19,35$

IMPLEMENTATION 30, 363, 367, 373

IMPOUNDMENTS $21,41,300$

INCINERATORS 253

INDUSTRIAL PLANTS 20, 25, 348

INDUSTRIAL WASTES 42

INFORMATION $25,87,101,201,213,226$, $239,331,350,359,380$

INFORMATION DISSEMINATION 350

INFORMATION RETRIEVAL 299

INFORMATION SYSTEMS $110,201,359$, 360,382

INHALATION 327 
INORGANIC ACIDS 163,333

INSPECTION 12, 159, 172, 189, 203, 242

INSTITUTIONAL FACTORS 64, 143, 144, 162

\section{INSULATION 7}

INTERAGENCY COOPERATION 378

INTERIM RESPONSE ACTIONS 33

INTERMEDIATE-LEVEL RADIOACTIVE WASTES $111,134,182,213$

INTERNATIONAL COOPERATION 218

INTERNATIONAL ORGANIZATTONS 76, 113,189

INVENTORIES $55,158,168,192,237,239$, $246,345,352$

ION EXCHANGE MATEPIALS 136, 145, $182,226,227,237$

IRON ALLOYS 35, 36, 38, 62, 66, 76, 79, $124,186,189,213,214,226$

IRON BASE ALLOYS $35,36,38,62,66,76$, $79,124,186,189,213,214,225,226$

IRRADIATION 35,36

IRRADIATION REACTORS 35, 169, 225

ISOTOPE PRODUCITON REACTORS 35 , 169,225

ISOTOPE RATIO 204

JETS $53,84,129,142,156,172,174,198$, $208,254,259$

JPDR REACTOR 103, 108, 154, 221, 237 , 238
KILNS 253

LABORATORY EQUIPMENT 56, 193, 207, $213,235,236$

LAND POLLUTION 34,335

LAND RECLAMATION $266,318,335$

LAND USE 90

LASER BEAM MACHINING 53, 57, 65, $128,184,256$

LASERS $128,233,256$

LAWS $121,363,370,378,379$

LEACHATES 326

LEACHING 60), 109, 145, 209, 294, 331-333

LEAD 329,331

LEAD-210 294

LEAKS 98

LEGISLATION 338

LICENSES $63,69,85,121,140,178,179$, 245,271

LICENSING $89,110,121,159,164,203,218$, $220,228,241,245,247,248,257,323$

LINGEN REACTOR 168, 239, 252, 2.55

LIQUID METAL COOLED REACTORS 9$)$

LIQUID WASTES $40,68,97,11 \hat{i}, 176,182$, $217,244,293,372,375$

LOFT REACTOR 189 
LOW - VEL RADIOACTIVE WASTES 6, 7, 6. 77, 80, 87, 109, 157, 182, 210, 213, $298,330,345,347,349,372,380$

\section{LUNGS 327}

LYSIS 225

MACHIN:NG 62, 134, 166, 186

MAGN: 277

MAGNETIC SURVEYS 284

MAGNOX TYPE REACTORS 74, 143, 144, $148,162,182,197,240.265$

MAINTENANCE $1,84,90,124,156,164$, $167,199,207,217,218,323,324$

MAMMALS 322

MANHATTAN PROJ:CT 275

MANIPULATORS 207

MANUALS $18,34,285,394$

MARITIME ADMINISTRATION 245

MARITIME TRANSPORT 37,39

MATERIAIS HANDLING 166, 218, 320, 394

MATERIALS HANDLING EQUIPMENT $134,186,205,207$

MATERIALS TESTING REACIORS 225

MATHEMATICAL MODELS 188, 262, 352, 366

MEASURINC METHODS 12, 105, 108, 218, 2.37
MECHANICAL PROPERTIES 9, 35, 36, 38, 62

MECHANICAL STRUCTURES 36, 214

MECHANICAL TESTS 4, 8, 19, 36

MECHANICS 218

MELTING 82, 96, 105, 108, 124, 191

MERCURY 22

METALLURGY 38,267

METALS $56,102,131,132,157,177,193$, $256,267,293,302,306,315,318,331-334$, $336,3.48$

\section{METEOROLOGY 335}

MICROORGANISMS 80, 334

MICROPROCESSORS 2.08

MICROSCOPY 38, 213

MIGRATION 23

MILITARY FACILITIES 246,369

MULING $317,321,322,341$

MINERAL RESOURCES 336

MINERAL WASTES 304

MINERALS 332,333

MINES 203, 304, 330, 336, 340

MINIMIZATION 235, 370

MINING $71,:-\because 313,330,338,340,345$

MINING WASIRES 326 
MIXED OXIDE FUELS 223

MIXED WASTES $13,45,275,293.364,372$, 393

MODELING $112,155,200,209,262,359$

MOISTURE 25

MOLYBDENUM 28

MOLYBDENUM ALLOYS 226

MZFR REACTOR 169

NAI DETECTORS $325,343,348$

NATIONAL ENVIRONMENTAL POLICY ACT $23,307,323,373$

NATURAL URANIUM REACTORS 134, 169,265

NEON-24 268

NEUTRON FLUX 35, 59

NICKEL 28

NICKEL ALLOYS 186, 214, 226

NICKEL BASE ALLOYS 214

NICKEL-59 139

NIEDERAICHBACH REACTOR 169, 220, 239,252

NITRATES 28

NOZZLES $53,84,129,156,172,174,198$, 208

NS SAVANNAH 245

NUCLEAR FUELS $20.96,98,130,214,223$, $258,259,338$
NUCLEAR POWER PLANTS 37, 39, 44, 50, $66,67,91,95,101,106,1.3120,125,126$, $159,160,167,185-187,194,197,206,207$, $222,224,246-248,252$

NUCLEAR SHIPS 245, 246

NUMERICAL SOLUTION 8

OCCUPATIONAL EXPOSURE 34, 45, 235, 327

OCCUPATIONAL SAFETY 45, 69, 201, $203,218,367$

OPTICAL ANALYSIS 233

OPTIMIZATION 166

ORE PROCESSIING $313,314,329,331$

ORES 332

ORGANIC ACIDS 157,217

ORGANIC COMPOUNDS 40, 226, 293, 332, 333

OXALIC ACID 217

OXIDATION 118, 119, 152, 217, 226, 227

OXIDES $157,331-333$

OXYGEN 53

OXYGEN COMPOUNDS $30,38,54,225$, $281,282,292,302,304,331-333,340$

PACKAGING $4,19,49,59,203,381$

PARTICLE SIZE 95, 215

PAVEMENTS 84

PERFORMANCE $1,45,94,127,129,218$, 238,253 
IERFORMANCE TESTING 5, 154, 166, 215

PERMEABILTTY 314

PERMITS 377

PERSONNEL 22, 56, 72, 75, 92, 122, 127, $135,137,219,221,235,257,327,330,371$

PETROLEUM 40

PHASE STUDIES 62

PHASE TRANSFORMATIONS 124, 145, 226, 244

PHOSPHATES 161

PHOSPHORIC ACID 82, 163

PHWR TYPE REACTORS 106,169

PHYSICAL PROPERTIES 9, 62, 112, 200, 209, 242, 262, 314

PILOT PLANTS 71, 253

PIPELINES 231, 232

PIPES $1,38,44,79,135,142,156,170,213$, 214

PLANNING $6,22,30,37,39,63,69,75,87$, $90,116,121,140,141,146,162,178,179$, $195,197,210,214,225,228,243,258,265$, $270,271,275,307,315,320,323,345,355$, $359,360), 362,363,365,367,370,374,377$, $380,381,383,386-393$

PLASMA ARC CUTTING 53, 57, 129, 149, $175,183,211,263,267$

PLASMA JETS 211

PLASTICS 254

PLATES 62
PLUMES 288

PLUTONIUM 56, 58, 71, 75, 93, 191, 193, 223, 259, 349

PLUTONIUM COMPOUNDS 6

PLUTONIUM PPODUCTION REACTORS 134,158

PLUTONIUM-239 237

POLICY 260

POLLUTION CONTROL 215

POLLUTION CONTROL EQUIPMENT 166,253

POLLUTION LAWS $354,378,379$

POLYETHYLENES 226

POLYMERS 226

PONDS 2, 3, 14, 21, 26, 27, 33, 41, 326

POPULATIONS $34,346,360$

POROSITY 109, 145

PORTABLE EQUIPMENT 278

POWER DEMAND 126

POWER REACTORS 4, 6, 8, 12, 19, 35, 36, $38,49,55,79,154,163,165,168,169,177$, $189,204,213,214,218,220,230,238,239$, 255,265

PRECIPITATION 75, 313

PRESSURE MEASUREMENT 5

PRESSURE VESSELS $4,8,11,35,38,49$, 114, 213, 214, 221 
TRIMARY COOLANT CIRCUITS 38,91 , $154,199,204,213,214,225$

PRIMARY SYSTEMS 91

PROBABILITY 12,127

PROCESSING $31,90,145,186,236,299$, 315,331

PROCUREMENT 38

PRODUCTION REACTORS 134, 158

PUBLIC HEALTH $140,141,249,330,337$, $367,370,373,375,382,386,387$

PUBLIC INFORMATION 41, 43, 87

PUBLIC OPINION $39,41,43,69,70,126$, $133,138,143,144,195,196,265,301,307$, $337,339,354,381,388$

PUBLIC POLICY 41, 276, 307, 354, 382, 388, 390

PUBLIC RELATIONS 41, 70, 138, 143, 144, 195,307

PULSED-FLOW TEST 60

PUMPS 1, 53, 79, 84, 135, 142, 19!, ?17, 317

PUREX PROCESS 97, 176

PWR TYPE REACTORS 4, 8, 12, !9, 35, 36, $38,49,55,79,90,91,126,165,177,181$, $187,189,197,199,210,213,214,218,226$, 239,257

PYROLYSIS 38, 226

QUALITY ASSURANCE 32, 218, 319, 323, 3.24, 367, 371

QUANTITATTVE CHEMICAL ANALYSIS 25,214
QUANTTTY RATIO 333

QUARRIES 2, 3, 14, 21, 26, 27

RADAR SURVEYS 284

RADIATION CONTROL 45

RADIATION DETECTORS $102,296,348$

RADIATION DOSE DISTRIBUTIONS 124 , 347

RADIATION DOSES $49,75,76,92,113$, $122,137,153,155,165,183,193,221,229$, $235,238,250,298,327,347,367$

RADIATION EFFECTS 35, 36, 155, 213

RADIATION HAZARDS 330, 367

RADIATION MONITORING $12,25,42$, $102,204,213,218,249,250,274,278-283$, $305,309-312,335$

RADIATION PROTECTION 30, 45, 73, 76, $82,92,117,121-124,134,137,159,165,178$, $181,193,203,207,210,216,218,219,221$, $225,229,249,258,295,296,305,309,311$. $312,327,328,341,347,385$

RADIATION PROTECTION LAWS 110, 241, 252

RADIATION SOURCES 155

RADIOACTIVATION 168

RADIOACTIVE AEROSOLS 155, 166, 205, $2: 5,335$

RADIOACTIVE MINEKALS 332,333

RADIOACTIVE WASTE HANDLING 45, 223 
RADIOACTIVE WASTE PROCESSING $45,102,145,186,236,259,293,315,375$

RADIOACTIVE WASTE STORAGE 30, $51,64,134,265,375$

RADIOACTIVITY LOGGING 281-283

RADIOCHEMICAL ANALYSIS 153, 214

RADIOCHEMISTRY 213,235

RADIOECOLOGICAL CONCENTRATION $25,30,42,158,268,269,274,278-283,297$. 335

RADIOMETRIC ANALYSIS $17,31,98,102$, $105,108,237,242,272,273$

RADIOMETRIC SURVEYS 17, 31, 103, 272, 273, 277, 287, 289-291, 294, 297, 305, $309-312,351$

RADIONUCLIDE KINETICS 218, 237

RADIONUCLIDE MIGRATION 21, 23, 24, $41,286,302,303,331,348,358$

RADIUM 2.85, 294, 297, 302, 331, 332

RADIUM ISOTOPES 25, 268, 269, 278-283, $333,334,340,348$

RADIUM-226 13, 25, 29, 42, 268, 269, 277-283, 289-291, 294, 305, 309, 316, 333, $334,340,348$

RADIUM-228 13, 32, 275

RADON 32, 285, 295, 296, 305, 309-312, 320, 344

RADON ISOTOPES $30,274,318,335$

RADON-220 274, 342
RADON-222 29, 30, 42, 274, 316, 318, 335, 342

RAFFINATES 21

RAIL TRANSPORT $289-291$

RANGER DEPOSIT 336

RARE GASES 295, 296

RATE STRUCTURE $143,144,150$

RESOURCE CONSERVATION AND RECOVERY ACT 293, 362

REACTOR ACCIDENTS 8, 165, 177, 189, 218,257

REACTOR COMPONENTS 9, 12, 38, 79, $90,91,99,102,104,135,154,161,168,175$, $179,189,190,192,199,204,213,214,218$, 225-227, 239, 242, 250, 257

REACTOR COOLING SYSTEMS 38, 44, 154, 199, 204, 213, 214, 225, 239

REACTOR CORE RESTRAINTS 130

REACTOR CORES 96, 130, 175, 211, 213, $214,218,226$

REACTOR DEFUELING 133, 175

REACTOR EXPERIMENTAL FACILITIES 59,246

REACTOR INTERNALS 59, 96

REACTOR LICEIJSING 247, 257

REACTOR MAINTENANCE 90, 124, 192, $199,218,245,250$

REACTOR MATERIALS 38, 109, 130, 186, $213,214,237$ 
REACTOR OPERATION $59,90,91,126$, $159,245,264$

REACTOR SAFETY $12,44,79,90,91,127$, $189,194,213,214,218,257$

REACTOR TECHNOLOGY 59

REACTOR VESSELS $7,19,36,86,212,218$, 222,250

REAGENTS 117, 227

RECOMMENDATIONS $63,69,76,90,185$, $203,218,244,271,315,339,354,366,369$, 377

RECYCLING 76,105,108,124, 146, 163, 210,372

REDOX PROCESS 154, 212

REDUCTION $118,119,151$

REGENERATION 82

REGRESSION ANALYSIS 308, 335

REGULATIONS $12,32,40,54,89,110,121$, $140,141,150,159,164,203,228,245,247$, $248,252,270,275,276,304,306,319,324$, $338,341,349,356-358,360,363-365,367$, $369-371,375,382,384,385,389,393$

REGULATORY GUIDES 121, 213, 249, 356,388

RELEASE LIMITS $31,47,48,102,105,108$, 229,351

RELIABILITY 50, 214, 257

REMOTE CONTROL $88,104,120,172,175$, $207,211,218,243,254,266$

REMOTE HANDLING 65, 120, 153, 207, $223,235,243$
REMOTE HANDLING EQUIPMENT 134 , 186, 207, 211

REMOTE VIEWING EQUIPMENT 172

REMOVAL 1, 6, 11, 30, 46, 49, 75, 93, 114, $156,177,180,202,215,226,268,298,354$

REPORTING REQUIREMEATTS 32, 239, 375

REPROCESSING $20,51,135,154,207,223$, 240

RESEARCH AND TEST REACTORS 6, 35, $154,169,189,225,238,239$

RESEARCH REACTORS 35, 169, 225, 258

RESIDENTIAL BUILDINGS 279, 280, 283, 295

RESINS 226, 227

RESISTIVITY SURVEYS 284

RESOURCE MANAGEMENT 375

RESPIRATORY PROTECTION 210

REVIEWS 47, 48, 82, 85, 143, 144, 272, 273, $287,305,309-312,324,354,357,358,383$, 390

RISK ASSESSMENT 12-14, 34, 127, 188, $203,213,216,218,25 \%, 264,327,330,347$, $360,363,371,389,393$

RIVERS $21,33,41,54,: 25,328$

ROADS 320

ROBOTS 149, 207, 210, 218, 254, 266

RUNOFF $21,33,41$ 
RWE-BAYERNWERK REACTOR 79, 163, $168,213,230,239,255$

SAFETY $1,4,10,12,30,37,50,79,84,90$, $114,127,140,141,159,164,189,203,213$, $214,218,239,245,250,255,257,264,271$, $305,309,311,312,319,337,375,385-387$, 394

SAFETY STANDARDS $76,116,124,127$, $159,194,241$

SALTS 80, 182

SAND 314,317

SUPERFUND AMENDMENTS AND REAUTHORIZATION ACT 23

SATURATION 5

SCALE MODELS 4

SCANNING ELECTRON MICROSCOPY 213

SCHEDULES $15,37,74,84,239,243,251$, $324,381,383,388,389,392$

SCINTILLATION COUNTERS 348

SCRAP 76, 82, 102, 105, 108, 124, 170

SCRUBBERS 253

SCRUBBING 165

SECURITY 116,249

SEDIMENTS 278, 282, 283

SEEPAGE 23, 329

SELENIUM 28

SENSITIVITY ANALYSIS 355
SEPARATION PROCESSES 51, 145, 154, $166,207,331-334$

SERVICE LIFE 79, 80, 194

SETTLING BASINS 326

SEWER LINES 343

SHEARING 53

SHIEL.DING 9, 11, 35, 36, 46, 120, 214, 222

SHIELDING MATERIALS 38, 213

SHIPPINGPORT REACTOR $1,4,8,9,11$, $12,16,18,19,35,36,38,39,45-49,79,148$, $213,214,239$

SHUTDOWNS 164, 180, 242, 246, 252

SILVER 130

SIMULATION $8,19,61,117,127,151,206$, $215,218,248$

SITE CHARACTERIZATION 13, 23, 40, 47, $48,277,288-292,294,322,348,352,363$, 385,393

SITE PREPARATION 30

SITE SELECTION 324

SITE SURVEYS $2,3,14,17,26,27,31,42$, 272-275, 277-283, 287, 289-291, 297, 322, 324,351

SIZE $56,95,215$

SLAGS 145

SLUDGES 21, 29, 41, 45, 97, 176, 293

SODIUM 28 
SOILS $5,17,19,25,29,32,34,42,71,155$, $229,268,272,273,275,277-283,285$, 289-291, 294, 296-298, 303, 305, 308-312, $314,316,318,321,322,331,335,337,346$, $348,351,353,366,380,381,389$

SOLIDIFICATION $68,97,145,176,226$, 244,250

SOLS 95

SOLUTIONS $100,157,161,165$

SOLVENT EXTRACTION 182

SORPTION 173

SPECTRA 213

SPECTROSCOPY 25,214

SPENT FUEL ELEMENTS 213

SPENT FUEL STORAGE 51, 56, 116, 213, 221

SPENT FUELS 116, 182, 214, 250, 349

STABILIZATION 298, 320, 339

STACKS 20, 134, 143, 144, 223

STAINLESS STEEL-304 226

STAINLESS STEELS 38, 79, 100, 118, 119, $136,152,173,186,213,214,226$

STANDARDS 23, 76, 124, 127, 228, 229, 249, $298,315,324,341,347,374,379$

STATE GOVERNMENT $357,358,390$

STATISTICS 335

STEAM GENERATORS 91, 192, 199, 218

STEAM SYSTEMS 213
STEEL-ASTM-A212 35

STEEL_CR18NI10II 186

STEELS 35, 36, 38, 53, 62, 66, 76, 79, 105 , $108,124,128,146,170,172,186,189,213$, $214,226,263,267$

STORAGE 30, 51, 56, 64, 68, 75, 93, 94, 12.3, $134,180,213,234,235,265,345,394$

STORAGE FACILITIES 5, 223, 226, 284

STRATIGRAPHY 300

STRESSES 8, 174, 261

STRONTIUM ISOTOPES 165

STRONTIUM SEMIWORKS COMPLEX 20

STRONTIUM-9097, 139, 165, 176, 286

STRUCTURAL MODELS 4, 80, 95

SUBSTRATES 313

SULFURIC ACID 136

SURFACE CONTAMINATION 124,136 , $155,163,165,177,204$

SURFACE FINISHING 177

SURFACE PROPERTIES 12

SURFACE WATERS $13,21,23,30,33,41$, 54,322

SURFACE'; 91, 99, 104, 105, 108, 152, 155, $157,173,346$

SURFACTANTS 165

SURVEILLANCE $75,116,123,143,144$, $159,164,194,245,286,305,309-312,323$, 324 
SYSTEMS ANALYSIS 218

TAILINGS DISPOSAL $\quad 314,329$

TANK TYPE REACTORS 35, 169, 189, 225

TANKS $135,345,389$

TAR 332,333

TAXES 338

TECHNOLOGY ASSESSMENT 56, 90, 128, $213,218,254,370,372,374$

TECHNOLOGY DEVELOPMENT 71, 104, $107,118,119,374,390$

TECHNOLOGY TRANSFER $18,37,46,78$, 372

TECHNOLOGY UTILIZATION 72,372

TEMPERATURE EFFECTS 226

TEST FACILITIES 287

TEST REACTORS $35,169,189$

THERMAL DEGRADATION 38,79

THERMAL EXCURSIONS 227

THERMAL POWER PLANTS 50, 66. 95, 101, 126, 185, 186, 206, 207, 247, 248

THERMAL TREATMENT 293

THERMOCHEMICAL PROC ESSES 38, 226

THERMODYNAMICS 218

THERMONUCLEAR REACTORS 207

THICKNESS 62

THOREX WASTES 97, 176
THORIUM 31, 285, 302, 332, 333, 342, 349

THORIUM COMPOUNDS 333

THORIUM ISOTOPES $25,268,269,274$, 279.283

THORIUM-230 13, 25, 32, 42, 268, 289-291, 305, 309, 316

THORIUM-232 268, 269, 274, 275, 279-283

THREE MILE ISLAND-2 REACTOR 92, $96,98,122,130,133,137,165,175,177$, $189,211,218,219,234,239,251$

TIME DEPENDENCE $123,126,265,333$

TITANIUM ADDITIONS 186

TITANIUM ALLOYS 226

TOLUENE 319

TOOLS 57, 62, 156, 172, 174, 186, 208

TRAINING 18, 218, 367, 371, 394

TRANSITION ELEMENT COMPOUNDS $38,332,333$

TRANSPORT $8,11,19,23,30,37,39,49,56$, $87,93,178,196,218,303,320$

TRANSPORTATION 39, 116

TRANSPORTATION SYSTEMS 370

TRANSURANIUM COMPOUNDS 6

TRANSURANIUM ELEMENTS 56, 193, 349

TRIGA TYPE REACTORS 178,239

TRITIUM 109, 173, 225, 237, 286 
TRUCKS 30

TUBES 186

TUNGSTEN 100

UNDERGROUND DISPOSAL 50, 226

UNDERGROUND FACILITIES 203, 304, $330,336,340$

UNDERGROUND STORAGE 121

UNDERWATER OPERATIONS 88,149 , 175

UPTAKE 318

URANINITES 332,333

URANIUM COMPOUNDS 331

URANIUM DEPOSITS 336

URANIUM ISOTOPES 268, 269

URANIUM MILLS 21, 41, 324, 327

URANIUM MINES 203, 300, 304, 313, 324, $325,328,330,336-338,341$

URANIUM ORES 313, 314, 329, 332, 338

URANIUM OXIDES 331

URANIUM-230 275

URANIUM-238 13, 268, 269, 289-291

URBAN AREAS 241

URINE 327

VACUUM BLASTING 45

VAK REACTOR 255
VALIDATION 206,354

VALVES $1,38,79,198,199,231,232$

VANADIUM 321,322

VAPOR GENERATORS 192,199

VEGETATION 294, 318, 322, 340

VEHICLES 30, 266

VENTILATION 65, 75, 296

VENTILATION SYSTEMS 166, 287

VISCOSITY 112, 200, 262

VITRIFICATION $60,61,97,111,112,151$, $176,182,200,202,209,253,262$

VOLATILE ORGANIC COMPOUNDS 293

VOLUME 259,297

VOLUME REDUCTION 97, 103, 176, 191, 259

WAGR REACTOR 65, 67, 148, 243

WASHING 153

WASTE MANAGEMENT 226

WASTE PACKAGING 45, 243

WASTE PROCESSING $60,61,97,111,112$, $145,151,176,182,186,200,209,227,236$, $259,262,315$

WASTE PROCESSING PLANTS 68,182 , 191,348

WASTE PRODUCT UTILIZATION 300

WASTE STORAGE $2,3,5,14,26,27,30$, $45,51,64,111,134,171,265,357$ 
WASTE TRANSPORTATION 3, 26, 56, 218, 289-291, 357

WASTE WATER $2,3,14,26,27,40$

WATER CHEMISTRY 218

WATER COOLED REACTORS 4, 6, 8, 12 , $19,35,36,38,49,55,79,90,91,106,126$, $154,163,165,168,177,181,189,199,213$, $214,218,226,227,230,238,239,255,257$, 306

WATER MODERATED REACTORS 4, 6 , $8,12,19,35,36,38,49,55,79,90,126,154$, $163,165,168,177,181,189,199,213,214$, $218,226,230,238,239,255,257,306$

WATER POLLUTION 34, 313, 328

WATER POLLUTION ABATEMENT 380

WATER POLLUTION CONTROL 21, 41

WATER QUALJTY 303

WATER REMOVAL $21,41,226,293,317$

WATER STORAGE TANKS 44

WATER TREATMENT 30
WATER TREATMENT PLANTS 21, 41

WELDED JOINTS 38

WELL LOGGING 281-283

WHLLS 28, 43, 286, 288, 317

WEST VALLEY DEMONSTRATION PROJECT 97, 112, 176, 200, 209, 262

WEST VALLEY PROCESSING PLANT 60, $61,68,87,151$.

WINDSCALE PRODUCTION REACTORS 134

ZEOLITE IE-9697, 176

ZINC 331

ZINC-65 158

ZIRCALOY 214

ZIRCONIUM ALIOYS 214

ZIRCONIUM BASE ALLOYS 214 

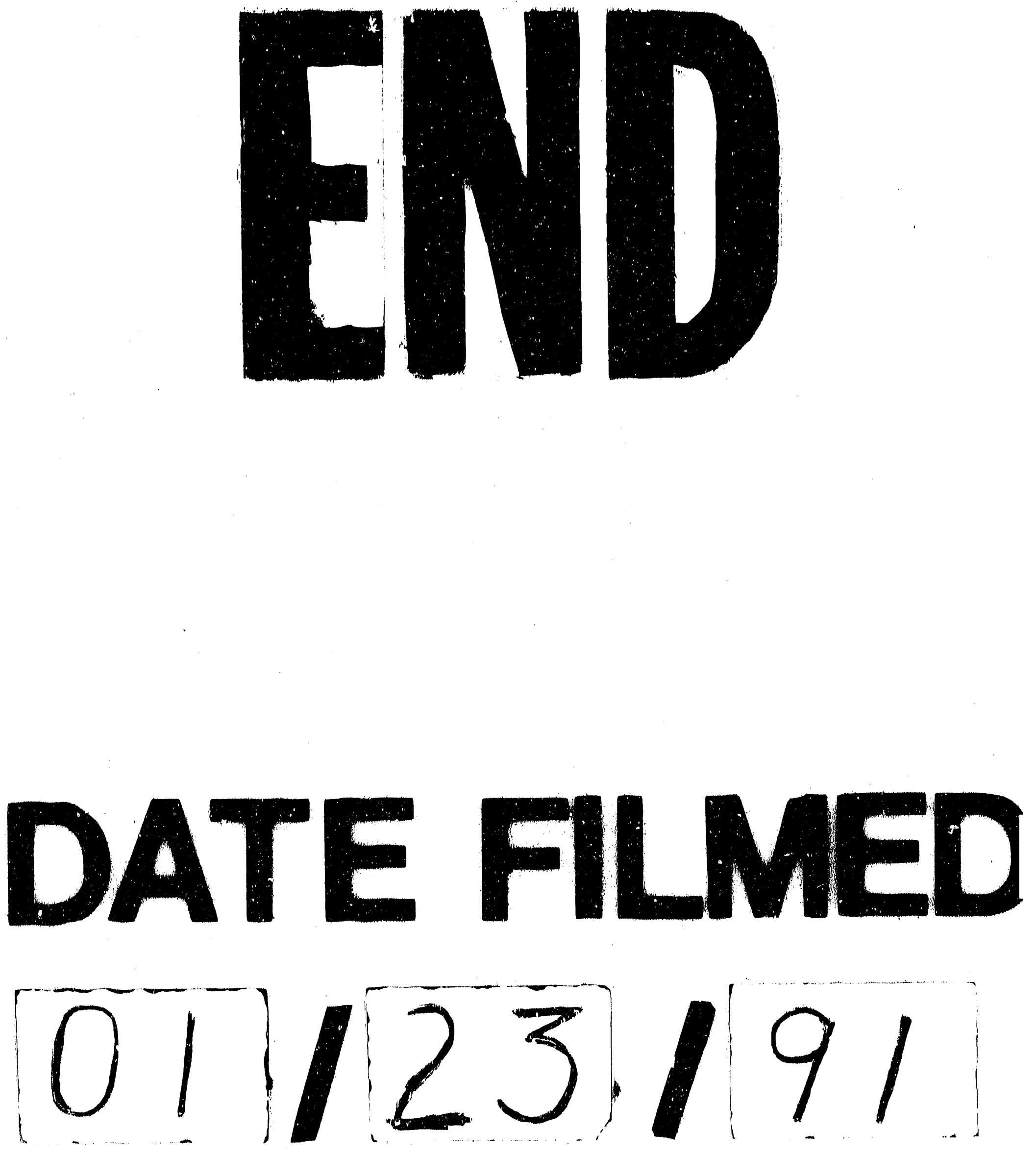
